\author{
UNIVERSIDADE DE SÃO PAULO \\ FACULDADE DE MEDICINA DE RIBEIRÃO PRETO
}

DANIELA DOS SANTOS MASSON

Atividades cicatrizante e antimicrobiana do óleo-resina de copaíba (Copaifera langsdorffii) em úlceras cutâneas

Ribeirão Preto

2011 


\section{Atividades cicatrizante e antimicrobiana do óleo-resina de copaíba (Copaifera langsdorffii) em úlceras cutâneas}

\begin{abstract}
Tese apresentada à Faculdade de Medicina de Ribeirão Preto da Universidade de São Paulo para obtenção do título de Doutor em Ciências Médicas, Programa de Pós-Graduação em Clínica Médica.
\end{abstract}

Área de Concentração: Clínica Médica Investigação Biomédica.

Orientador: Prof. Dr. Marco Andrey Cipriani Frade

Ribeirão Preto 
AUTORIZO A REPRODUÇÃO E DIVULGAÇÃO TOTAL OU PARCIAL DESTE TRABALHO POR QUALQUER MEIO CONVENCIONAL OU ELETRÔNICO PARA FINS DE ESTUDO E PESQUISA, DESDE QUE SEJA CITADA A FONTE.

\section{Catalogação da publicação}

Faculdade de Medicina de Ribeirão Preto da Universidade de São Paulo

\section{FICHA CATALOGRÁFICA}

Masson, Daniela dos Santos

Atividades cicatrizante e antimicrobiana do óleo-resina de copaíba

(Copaifera langsdorffii) em úlceras cutâneas. Ribeirão Preto, 2011.

215 f.: il.; $30 \mathrm{~cm}$

Tese de Doutorado, apresentada à Faculdade de Medicina de Ribeirão Preto da Universidade de São Paulo. Área de Concentração:

Clínica Médica - Investigação Biomédica.

Orientador: Frade, Marco Andrey Cipriani

1. Cicatrização de feridas

2. Fitoterapia

3. Copaifera langsdorffii

4. Modelos animais

5. Eficácia

6. Segurança 


\section{FOLHA DE APROVAÇÃO}

MASSON, Daniela dos Santos

Atividades cicatrizante e antimicrobiana do óleo-resina de copaíba (Copaifera langsdorffii) em úlceras cutâneas.

Tese apresentada à Faculdade de Medicina de Ribeirão Preto da Universidade de São Paulo para obtenção do título de Doutor em Ciências Médicas, Programa de PósGraduação em Clínica Médica.

Área de Concentração: Clínica Médica Investigação Biomédica

Aprovado em ___

\section{COMISSÃO JULGADORA}

Prof. Dr.:

Instituição:

Assinatura:

Prof. Dr.:

Instituição:

Assinatura:

Prof. Dr.:

Instituição:

Assinatura:

Prof. Dr.:

Instituição:

Assinatura:

Prof. Dr.:

Instituição: Assinatura: 


\section{Dedicatóría}

Aos meus pais, Cleuza e Roberto Masson, exemplos de determinação e luta, pelo amor incondicional, por apoiarem as minhas escolhas, por entenderem que a distância se faz necessária para o meu crescimento profissional, pelas orações, telefonemas, visitas e agradáveis conversas virtuais quando as visitas não eram possíveis. Por cada palavra de incentivo, pela paciência infinita e por sempre terem sido exemplos de como sermos pessoas melhores a cada dia... Agradeço pela educação que me proporcionaram durante toda a minha vida! Agradeço por ser filha de vocês, e como sempre digo: vocês são os melhores pais do MUNDO!

Àquele que chegou da maneira mais inesperada, porém de forma tão intensa trazendo paz para o meu coração e completando minha vida: John, obrigada pela admiração e respeito que você tem por mim e por sempre me ouvir e me aconselhar! Obrigada pelas incontáveis horas que você, pacientemente, me ouviu falando sobre cicatrização e sobre os experimentos. Sou muito grata pelo seu imenso apoio durante a fase mais longa desta jornada, não sei se eu teria tido forças suficientes para enfrentar as barreiras se eu não tivesse você em minha vida e o nosso amor que preenche o meu coração de alegria. Obrigada por fazer cada dia diferente do anterior, por me fazer a cada dia mais feliz e por fazer minha vida valer a pena! "É.. só eu sei quanto amor eu guardei e era só prá você.."

Chegar até aqui não foi nada fácil e se hoje comemoramos uma conquista, esta se deve àqueles que estiveram ao meu lado em todos os momentos, que fizeram de meus sonhos os seus e de mens objetivos sua própria luta. Quero compartithar esta conquista com vocês, as pessoas mais importantes da minha vida, que não pouparam esforços para que $\sigma$ sorriso que hoje trago no rosto fosse possivel. Foram muitas vezes que vocês foram mens escudos, em que despejei minhas frustrações, mas $\sigma$ amor sempre foi maior e no momento seguinte vocês estavam lá para me reerguer através do seu apoio incondicional. Nos momentos importantes, suportaram minha ausência; nos dias de fracasso, respeitaram meus sentimentose enxugaram minhas lágrimas. Dizer a vocês obrigada não é suficiente para expressar $\sigma$ men sentimento de gratidão, pois $\sigma$ amor que sinto por vocês fala mais alto nessa hora e não há outra forma de agradecer a não ser dizendo agora e sempre que EU AMO MUITO VOCÊS! 


\section{Agradecimentos Especiais}

Ao meu orientador Dr. Marco Andrey Cipriani Frade. É muito difícil encontrar palavras para agradecê-lo... Obrigada por acreditar em mim e me proporcionar esta oportunidade de aprender sobre cicatrização e as inúmeras possibilidades de investigação científica na pesquisa relacionada ao reparo tecidual. Nunca esquecerei nossas inúmeras tentativas de experimentos no laboratório sem hora para acabar! Foi muito importante tê-lo como orientador e principalmente como referência para minha vida profissional como pesquisadora! Admiro muito o seu entusiasmo pela pesquisa, o dinamismo de suas aulas e palestras, além do modo pelo qual você trata os seus pacientes, que é impressionante! Também o agradeço pelo seu carinho, sua amizade, e pelo seu grande empenho em me ajudar em muitos momentos. Você é e sempre será uma pessoa muito querida na minha vida, um exemplo! Sinto-me privilegiada por ter sido a sua primeira aluna de doutorado!

"Não sei o que combina mais contigo, uma poesia, um livro, uma pintura. Sinceramente fico pensando no que deve dar alegria a alguém que é objeto da alegria de tantos. Na verdade, o professor de verdade é aquele que prefere dividir o que possui, a ter somente para si. $O$ verdadeiro mestre sente-se feliz quando percebe que $\sigma$ caminho que ele abriu tem sido trithado por muitos. $O$ mestre tem a sua realização no aprendizado do pupito, da passagem da experiência. É por isso que meras palavras não podem recompensar alguém que optow por esta carreira. Obrigado por sua obstinação incontida, pois graças a ela, você nunca desiste e nos inspira". (Autor desconhecido)

Ao meu co-orientador durante o Programa de Doutorado no País com Estágio no Exterior (PDEE) no College of Health Sciences, University of Wisconsin-Milwaukee (UWM), EUA, professor Dr. Chukuka Samuel Enwemeka. Muito obrigada por me conceder esta oportunidade única! Eu já o admirava como profissional antes mesmo de conhecê-lo pessoalmente, e hoje posso dizer que o admiro ainda mais tanto como pesquisador quanto como exemplo de ser humano! Jamais esquecerei de todo o seu apoio desde quando cheguei a Milwaukee, de seu jeito tranquilo que me transmitiu calma em inúmeras vezes onde vários fatores dificultavam a execução da pesquisa proposta. Obrigada pelo seu apoio fundamental em relações às questões burocráticas que tiveram que ser resolvidas durante o estágio. Sou muito grata pela confiança que você depositou em mim desde o início, mesmo quando ainda não conhecia o meu trabalho, por tudo que aprendi durante a execução dos experimentos, discussão dos resultados e também durante a elaboração da apresentação para a defesa da tese. "Thank you so much"! 
Ao "irmão postiço", amigo e colega Thiago Antônio Moretti de Andrade, por desde o início mostrar-me a importância e a beleza em se estudar cicatrização. Sua paixão pela pesquisa científica e principalmente por esta área me fez ainda mais interessada no assunto. Lembro-me do ano de 2006 quando eu o conheci e a partir daí começaram os contatos com o professor Marco Andrey. Durante toda a jornada do doutorado sempre estivemos trabalhando juntos como amigos e nos ajudando, ora na execução dos experimentos, ora carregando nossas caixinhas de curativos etc.. Escrevendo e discutindo trabalhos científicos (mesmo "em virtude das dificuldades"), métodos, resultados e crescendo juntos como pesquisadores. Jamais me esquecerei de sua ajuda durante o meu estágio nos Estados Unidos, foi muito bom saber que mesmo fisicamente distantes, ainda continuávamos a trabalhar juntos. Serei eternamente grata a você pela ajuda com as questões burocráticas, e principalmente por você sempre compartilhar o seu conhecimento, me ajudando na elaboração da tese! "Desejo-thi" muito sucesso, e tenho certeza que você alcançará os objetivos que traçar, porque força de vontade e determinação não te faltam! Muito Obrigada!

\section{"Há homens que lutam um dia e são bons. Há outros que lutam um ano e são melhores. Há os que lutam muitos anos e são muito bons. Porém, há os que lutam toda a vida. Esses são imprescindíveis".}




\section{Agradecimentos}

À Deus, pela força durante cada minuto de apreensão e dificuldade, por me mostrar os caminhos a seguir, ter me dado saúde durante esta longa jornada, por colocar pessoas maravilhosas perto de mim, e principalmente, por me fazer acreditar num futuro que vai além do que me limitei a sonhar para mim. "Tudo posso naqueleque me fortalece." (Filipenses 4, 13).

À minha família pelo carinho e pelo apoio às minhas escolhas. Mesmo quando estamos distantes, sei que posso e sempre poderei contar com vocês. Muito obrigada!

Ao professor Dr. Sérgio Luiz S. Salvador pelo apoio à pesquisa proposta, disponibilização de seu laboratório, discussão dos métodos e resultados, além dos ensinamentos ao longo da execução dos experimentos, durante o Programa de Aperfeiçoamento ao Ensino, no qual o tive como supervisor e ainda por suas importantes considerações durante a finalização da tese. Agradeço ainda pelas nossas conversas sobre Pós-Graduação e sobre a importância de conhecer novos horizontes fora do país. Agradeço também à professora Dra. Juliana P. Falcão, pelos conhecimentos transmitidos. A todos os funcionários dos Laboratórios de Microbiologia, do Departamento de Análises Clínicas, Bromatológicas e Toxicológicas da Faculdade de Ciências Farmacêuticas de Ribeirão Preto (DACTB/FCFRP-USP), especialmente à técnica Maraísa P. Verri, muito obrigada!

À professora Dra. Norma T. Foss, exemplo de profissional, sempre muito atenciosa e prestativa para com minhas atividades de pós-graduação. Muito obrigada por acreditar em mim e por sempre estar disposta a ajudar no que fosse preciso!

Ao professor Dr. Joaquim Coutinho Neto, às técnicas Silvinha e Verinha do Laboratório de Bioquímica do Departamento de Bioquímica da Faculdade de Medicina de Ribeirão Preto (FMRPUSP) pela ajuda durante os experimentos com coelhos.

Aos professores da FMRP-USP: Dr. Carlos Eli Piccinato, Dr. Paulo Mazzoncini A. Marques e Dra. Valéria P. Sassoli Fazan, por terem sido membros da banca do exame de qualificação e terem contribuído com a minha formação profissional com suas críticas, comentários, sugestões e discussão

À professora Dra. Cláudia Martins Carneiro, da Universidade Federal de Ouro Preto, por ter prontamente aceito o convite em fazer parte da finalização deste trabalho, e pelo grande empenho e esmero em suas importantes considerações para a melhoria da tese. 
Ao professor Dr. Osvaldo de Freitas, do Departamento de Ciências Farmacêuticas da FCFRP-USP, por gentilmente nos fornecer o óleo-resina de copaíba.

À farmacêutica Rita Paula Ignácio e aos funcionários da Farmácia de Manipulação Doce Erva, pela manipulação dos cremes utilizados nos estudos.

Aos professores das disciplinas cursadas na FMRP-USP, durante o curso de doutorado.

Às professoras da Divisão de Dermatologia do Hospital das Clínicas da FMRP-USP, Dra. Ana Maria Roselino, Dra. Cacilda Silva e Souza, e às secretárias “Cris” e Wilde.

Ao cirurgião plástico Dr. Henrique C. Tardelli, por nos fornecer os fragmentos de pele advindos de cirurgia plástica de seus pacientes, aos funcionários do Centro Cirúrgico do Hospital das Clínicas da FMRP-USP pela ajuda prestada, e aos pacientes que gentilmente consentiram a utilização dos fragmentos de pele provenientes de suas cirurgias plásticas.

Aos professores e funcionários do Laboratório de Bioquímica (DACTB/FCFRP-USP), especialmente a técnica Ana Cristina M. Polizello. Obrigada "Cris" pelo apoio com os experimentos e discussão dos resultados. Neste laboratório não aprende-se somente ciência, mas também como sermos pessoas melhores! Agradeço ao mestrando Felipe Godoy pela imensurável ajuda, principalmente nos momentos mais "turbulentos" dos vários experimentos ao mesmo tempo! Aos alunos Cadu, Ingrid e Matheus pela colaboração. Ao professor Dr. Augusto César Cropanese Spadaro, obrigada por disponibilizar o uso de equipamentos e infra-estrutura do laboratório.

À professora Dra. Ana Lúcia da Costa Darini, por conceder o uso de equipamentos no Laboratório de Bacteriologia (DACTB/FCFRP-USP).

Aos funcionários do Biotério do Departamento de Clínica Médica da FMRP-USP: Adalberto, Maurício e Roni, pela ajuda nos experimentos e no cuidado com os coelhos.

À técnica Maria Aparecida Nunes, do Laboratório de Cultura Celular da Dermatologia da FMRP-USP. Obrigada “Cici” pela grande ajuda com os experimentos e pelos ensinamentos transmitidos. Obrigada também pelas agradáveis conversas e por ter me ouvido tantas vezes e me incentivado, quando eu quase não tinha mais forças para continuar o trabalho! 
Ao secretário do Programa de Pós-Graduação em Clínica Médica da FMRP-USP: Émerson Quirino de Oliveira, sempre muito prestativo e eficiente! E aos funcionários da Secretaria Geral de Pós-Graduação da FMRP-USP.

À técnica Marilena Herédia pelo processamento histológico das biópsias no início do trabalho.

Aos funcionários da Biblioteca Central do Campus da USP de Ribeirão Preto.

Aos amigos/colegas de Pós-Graduação (FMRP-USP): Ana Elisa Jorge, Carolina Oliveira, Cindy Okuma, Daniel Libanore, Daniela de Lucca, Débora Minatel, Luísiane Santana, Olivia Kim, Saulo Leite, Thania Cordeiro e Weber Coelho. Obrigada por compartilharem seus conhecimentos, pelo apoio e pelos momentos de descontração!

Aos professores do College of Health Sciences (CHS)-UWM: Dr. John Ndon, Dra. Janis Eells, Dra. Jeri-Annette Lyons e Dr. Robert Burlage, por terem me recebido tão bem, permitirem o uso de equipamentos em seus laboratórios e pelos conhecimentos transmitidos. "Thank you”!

Aos funcionários do CHS-UWM: Dra Berri Forman e Jennifer Nemke (pelo treinamento e ajuda com os animais de experimentação); Lauren Escobales, Sheila Anderson (pela ajuda com as questões burocráticas); Julie Thompson, Patti Sander (pela ajuda inicial com relação à instalação na cidade e na universidade e apoio durante o período do estágio); Susan Roskopf (pela ajuda inicial com compra de reagentes e uso dos laboratórios); Dra Violet Bumah (pela ajuda durante os experimentos com os animais e discussão dos resultados).

Aos colegas de Pós-Graduação do CHS-UWM: David Gallegos (pela ajuda fundamental durante a fase "já quase sem tempo e sem forças" para o término dos experimentos!); Priyanka Kshatriya e Richa Saxena ("vizinhas" de lab, pela ajuda em muitos momentos!); Sandeep Gopalakrishnan (pela ajuda com metodologias). "Thank you! Muchas Gracias! Shukriya”!

À família Meyers, especialmente, Jon, Raymond e Madelon e à família García, especialmente Angela e Roberto, muito obrigada por me acolherem com tanto afeto, por sempre mostrarem-se interessados em saber se os "meus ratinhos" estavam bem e por todo o apoio e carinho desde quando fomos colocados uns nas vidas dos outros!

À “irmãzinha” Gilsane Morais, obrigada por sua amizade, que começou lá atrás (2003) quando fizemos mestrado no mesmo lab. Os caminhos mudaram, cada uma foi para um laboratório diferente, mas nossa amizade continuou no mesmo caminho. É muito bom saber que posso contar 
contigo! Obrigada por ter cuidado do ap., por sempre me ajudar, especialmente na reta final deste trabalho!

Às amigas Bruna Paradello, Celita Kouzes, Camila Landim e Mirela Dias, pela amizade, ajuda e apoio sempre, mesmo fisicamente distantes em alguns momentos.

Ao Programa de Pós-Graduação em Clínica Médica (FMRP-USP) pela oportunidade de crescimento científico e pessoal!

À University of Wisconsin-Milwaukee, pela oportunidade da realização do estágio para a complementação dos estudos desenvolvidos durante o doutorado. Esta etapa foi extremamente importante para o meu crescimento profissional e pessoal, e um excelente meio para o intercâmbio de conhecimento entre Brasil e Estados Unidos, particularmente FMRP-USP e UWM.

A CAPES pela bolsa de doutorado, pela bolsa para a realização do programa PDEE $e$ principalmente pela compreensão de que o tempo adicional requerido seria/foi fundamental para a finalização do estágio no exterior e conclusão da tese. Muito Obrigada!

À FAEPA e à Pró-reitoria de Pós-Graduação (PRPG-USP) pelo apoio financeiro para participação em congressos.

A todos que direta, ou indiretamente, fizeram parte desta importante fase da minha vida e que contribuíram para a concretização deste trabalho, cujos nomes não figuram neste texto, mas estão presentes na memória e principalmente no coração! Muito Obrigada!

\section{"Agradeço todas as dificuldades que enfrentei; não fosse por elas, eu não teria saído do lugar". Chico Xavier}




\section{RESUMO}

MASSON, D.S. Atividades cicatrizante e antimicrobiana do óleo-resina de copaíba (Copaifera langsdorffii) em úlceras cutâneas. 2011. 215 f. Tese (Doutorado) - Faculdade de Medicina de Ribeirão Preto, Universidade de São Paulo, Ribeirão Preto, 2011.

O estudo avaliou o óleo-resina (OR) proveniente da Copaifera langsdorffii quanto: à citotoxicidade; ao potencial cicatrizante em modelos animais; aos efeitos no modelo ex vivo de cicatrização da pele humana; à atividade antimicrobiana in vitro e in vivo. A citotoxicidade do OR $(1,10,50,100,500$ e $1000 \mu \mathrm{g} / \mathrm{mL}$ ) foi avaliada em culturas de fibroblastos 3T3 pela determinação da viabilidade e proliferação celular. A atividade cicatrizante foi avaliada em úlceras cutâneas em orelha de coelho, com aplicações tópicas diárias, por 21 dias, do OR in natura e em creme (10 e 25\%) e controles [creme base ( $\mathrm{Cr}$ ) e solução fisiológica]; no dorso de ratos, o tratamento consistiu de creme a $10 \%$ e os mesmos controles, por 14 dias. As úlceras foram avaliadas por análise de imagem, índices de cicatrização e histologia nos dias 2, 7, 14 e 21. Parâmetros bioquímicos (hidroxiprolina e metaloproteinases) foram incluídos na investigação da cicatrização em ratos. No modelo ex vivo, os fragmentos de pele receberam diariamente: OR in natura, cremes a 10 e $25 \%$ e controles ( $\mathrm{Cr}$ e meio de cultura (DMEM), por 21 dias, e foram avaliados nos dias 0, 1, 3, 7, 14 e 21, por análises clínico-fotográfica e histológica. A atividade antimicrobiana in vitro foi avaliada pela determinação das concentrações inibitória e bactericida mínimas para bactérias Gram-positivas: S. aureus (ATCC 6538), S. pyogenes (ATCC 19615) e Enterococcus faecalis (ATCC 10541) e Gram-negativas: P. aeruginosa (ATCC 2327) e E. coli (ATCC 10538). A atividade antimicrobiana in vivo foi avaliada nas úlceras infectadas com $S$. aureus ou $S$. pyogenes em ratos, pela contagem bacteriana no exsudato e biópsias nos dias 2, 7 e 14 após úlceras e inoculação bacteriana além da atividade cicatrizante. O OR não apresentou toxicidade aos fibroblastos até $100 \mu \mathrm{g} / \mathrm{mL}$, com viabilidade e proliferação de 90 a $100 \%$. Promoveu melhor cicatrização a $10 \%$, nos modelos orelha de coelho e dorso de ratos, enquanto, in natura ocasionou agressão tecidual. O modelo ex vivo manteve-se viável por 21 dias; a $10 \%$ o OR inibiu a reepitelização das úlceras, diferente do controle (DMEM), evidenciando que sua atividade cicatrizante é dependente do processo inflamatório, ausente neste modelo. Apresentou atividade antimicrobiana in vitro (S. aureus, S. pyogenes e $E$. faecalis), a qual se manteve in vivo observada pelo estímulo cicatrizante do OR a $10 \%$ em creme nas úlceras infectadas com $S$. aureus ou $S$. pyogenes em ratos. Os resultados evidenciaram que o OR da C. langsdorffii não foi citotóxico, apresentou atividade antimicrobiana in vitro e in vivo, além de importante atividade cicatrizante dependente, essencialmente da fase inflamatória, demonstrada nos modelos animais e ausente no modelo ex vivo, contribuindo para o conhecimento quanto ao seu mecanismo de ação, eficácia e segurança para o uso clínico na cicatrização de úlceras cutâneas.

Palavras-chave: Cicatrização de feridas. Fitoterapia. Copaifera langsdorffii. Modelos animais. Eficácia. Segurança 


\begin{abstract}
MASSON, D. S. Healing and antimicrobial activities of copaiba oleoresin (Copaifera langsdorffii) on cutaneous wounds. 2011. $215 \mathrm{f}$. Thesis (Doctoral Degree) - Faculdade de Medicina de Ribeirão Preto, Universidade de São Paulo, Ribeirão Preto, 2011.
\end{abstract}

The study evaluated oleoresin (OR) obtained from Copaifera langsdorffii regarding its: cytotoxicity; wound healing potential in animal models; effects on the ex vivo model of human skin healing; and antimicrobial activity in vitro and in vivo. The cytotoxic effect of $\operatorname{OR}(1,10,50,100,500$ and $1000 \mu \mathrm{g} / \mathrm{mL})$ was assessed on 3 T3 fibroblasts by viability and proliferation assays. The wound healing activity was performed in a rabbit ear model, with daily topical treatment, over 21 days: in natura OR, and at 10 and $25 \%$ cream, and controls [base cream ( $\mathrm{Cr}$ ) and saline]; in dorsal wounds in rats, the treatment consisted of daily topical application of $10 \%$ OR cream and the same controls, over 14 days. The wounds were assessed by image analysis, wound healing rates and histology on days 2, 7 and 14. Biochemical tests (hydroxyproline and metalloproteinases) were included for the healing investigation in rats. In the ex vivo model, skin fragments received daily: in natura OR, 10 and 25\% creams, and controls ( $\mathrm{Cr}$ and culture medium (DMEM), for 21 days, and on days 0, 1, 3, 7, 14 and 21, fragments were analyzed by photographical and histological analyses. The in vitro antimicrobial activity was assessed by the minimal inhibitory and bactericidal concentrations assays, on Gram-positive: S. aureus (ATCC 6538), S. pyogenes (ATCC 19615) and Enterococcus faecalis (ATCC 10541) and Gram-negative: $P$. aeruginosa (ATCC 2327) and E. coli (ATCC 10538). The in vivo antimicrobial activity was assessed in wounds infected either with $S$. aureus or $S$. pyogenes, by bacterial count in the exudates and biopsies on days 2, 7 and 14 after wounding and bacterial inoculation, along with the healing activity. OR was not cytotoxic to fibroblasts up to $100 \mu \mathrm{g} / \mathrm{mL}$, showing 90 to $100 \%$ cell viability and proliferation. OR $10 \%$ cream enhanced healing in rabbits and in rats, however, in natura it caused aggression to the tissue. The ex vivo model was viable for 21 days; at $10 \%$ OR inhibited wound reepithelialization, different from the control (DMEM), showing evidence that healing properties of OR depend on the inflammatory phase, absent in this model. OR showed in vitro antimicrobial activity (S. aureus, S. pyogenes and $E$. faecalis), which was maintained in vivo, observed by a healing stimulus of $10 \%$ OR cream in wounds infected with $S$. aureus or $S$. pyogenes, in rats. The results showed that OR from $C$. langsdorffii showed no cytotoxicity, and presented in vitro and in vivo antimicrobial activity. It also enhanced healing, depending, essentially, on the inflammatory phase, demonstrated by the animal models of injury and repair and absent in the ex vivo model. These findings contribute to an understanding of the OR mechanism of action, efficacy and safety for clinical use in wound healing.

Keywords: Wound healing. Phytotherapy. Copaifera langsdorffii. Animal models. Efficacy. Safety. 


\section{LISTA DE FIGURAS}

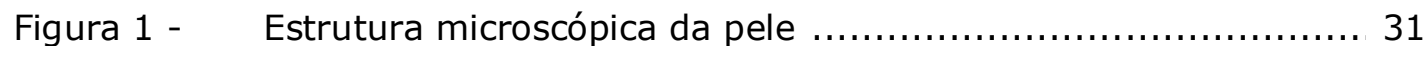

Figura 2 - Desequilíbrio na cicatrização, caracterização de úlceras

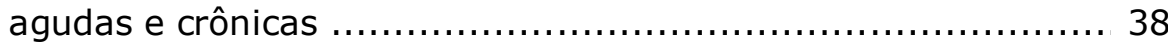

Figura 3 - $\quad$ Representação esquemática da pele íntegra (a) úlcera cutânea (b), característica do tecido cicatrizado (c) ......................4 42

Figura 4 - Representação das fases do processo cicatricial: (a) Úlcera imediatamente após a lesão tecidual; (b) Hemostasia; (c) Início da fase inflamatória; (d) Fase inflamatória tardia; (e) Fase Proliferativa; (f) Fase de remodelamento

Figura 5 - Representação do espectro de infecção em uma úlcera

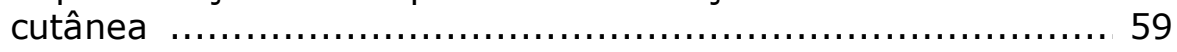

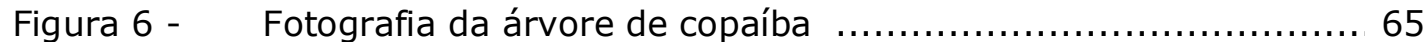

Figura 7 - Representação esquemática do procedimento de análise de imagens para o cálculo das áreas das úlceras pelo software ImageJ para posterior determinação dos valores dos ICUs $\ldots . . .83$

Figura 8 - Representação esquemática da disposição das amostras nos géis de zimografia

Figura 9 - $\quad$ Representação esquemática do procedimento de análise das bandas de digestão enzimática (densitometria) nos géis de zimografia em gelatina pelo software Image]

Figura 10 - Representação das placas de cultura de pele e da padronização dos tratamentos aplicados aos fragmentos: Óleo-resina in natura (OR); Cremes a $25 \%$ (C25) e a $10 \%$ (C10) do óleo-resina de copaíba; creme base $(\mathrm{Cr})$; meio de cultura (DMEM) (M)

Figura 11 - Representação esquemática do procedimento para a obtenção do inóculo a ser utilizado para os testes de sensibilidade bacteriana

Figura 12 - Fluxograma dos grupos de tratamento para a avaliação da atividade antimicrobiana in vivo do óleo-resina de copaíba (Estudo 6), assim como para a avaliação do seu potencial cicatrizante (Estudo 7)

Figura 13 - Representação esquemática da obtenção de amostra para a cultura microbiológica a partir das úlceras 
Figura 14 - Percentual de células viáveis em relação à cultura controle, distribuído conforme os tratamentos das culturas: Meio de cultura (M); Meio de cultura contendo DMSO (M+DMSO); Concentrações do óleo-resina de copaíba 1,$0 ; 10 ; 50 ; 100$; 500 e $1000 \mu \mathrm{g} / \mathrm{mL}$

Figura 15 - Resultado do teste MTT conforme absorbância das culturas, distribuído conforme os tratamentos das culturas: Meio de cultura (M); Meio de cultura contendo DMSO (M+DMSO); Concentrações do óleo-resina de copaíba 1,0;10; 50;100; 500 e $1000 \mu \mathrm{g} / \mathrm{mL}$

Figura 16 - Percentual de proliferação celular pela incorporação do $\mathrm{H}^{3}$ Timidina relativa a cultura controle conforme os tratamentos das culturas: Meio de cultura (M); Meio de cultura contendo DMSO (M+DMSO); Concentrações do óleo-resina de copaíba 1,$0 ; 10 ; 50 ; 100 ; 500$ e $1000 \mu \mathrm{L} / \mathrm{mL}$

Figura 17 - Contagem de células incorporadas $\left(\mathrm{H}^{3}\right.$-Timidina) por minuto distribuídas conforme os tratamentos das culturas: Meio de cultura (M); Meio de cultura contendo DMSO (M+DMSO); Concentrações do óleo-resina de copaíba 1,$0 ; 10 ; 50 ; 100$; 500 e $1000 \mu \mathrm{g} / \mathrm{mL}$

Figura 18 - Seguimento clínico das úlceras nos dias 0, 2, 7, 14 e 21 respectivamente, conforme os tratamentos: Solução fisiológica (Sf) (a-e); Creme base (Cr) (f-j); Creme a $10 \%$ (C10) (k-o) e a $25 \%$ de óleo-resina (C25) (p-t); Óleo-resina puro (OR) (u-y)

Figura 19 - Evolução dos índices de cicatrização das úlceras (ICUs) nos tempos de avaliação de 2, 7, 14 e 21 dias, conforme os tratamentos: Solução fisiológica (Sf), Creme base (Cr), Cremes a $10 \%$ (C10), a 25\% (C25) de óleo-resina de copaíba, óleo-resina puro (OR)

Figura 20 - $\quad$ Avaliação histopatológica das úlceras nos dias 2, 7, 14 e 21 respectivamente, conforme os tratamentos: Solução fisiológica (Sf) (a-d); Creme base (Cr) (e-h); Creme a 10\% (C10) (i-I) e a $25 \%$ de óleo-resina de copaíba (C25) (m-p); Óleo-resina puro (OR) (q-t). Coloração hematoxilina-eosina .... 119

Figura 21 - Avaliação histopatológica das úlceras nos dias 2, 7, 14 e 21 respectivamente, conforme os tratamentos: Solução fisiológica (Sf) (a-d); Creme base (Cr) (e-h); Creme a 10\% (C10) (i-l) e a 25\% de óleo-resina de copaíba (C25) (m-p); Óleo-resina puro (OR) (q-t). Coloração tricrômio de Gomori $\ldots . .120$

Figura 22 - Seguimento clínico das úlceras nos dias 0, 2, 7 e 14 respectivamente, conforme os tratamentos: Solução fisiológica (Sf) (a-d); Creme base (Cr) (e-h); Creme a 10\% de óleo-resina (C10) $(\mathrm{i}-\mathrm{I})$ 
Figura 23 - Evolução dos índices de cicatrização das úlceras (ICUs) nos tempos de avaliação de 2, 7 e 14 dias, conforme os tratamentos: Solução fisiológica (Sf), Creme base (Cr), Creme a $10 \%$ de óleo-resina de copaíba (C10)

Figura 24 - Avaliação histopatológica das úlceras nos dias 2, 7 e 14 respectivamente, conforme os tratamentos: Solução fisiológica (Sf) (a-c); Creme base (Cr) (d-f); Creme a 10\% de óleo-resina de copaíba (C10) (g-i). Coloração HE

Figura 25 - Avaliação histopatológica das úlceras nos dias 2, 7 e 14 respectivamente, conforme os tratamentos: Solução fisiológica (Sf) (a-c); Creme base (Cr) (d-f); Creme a 10\% de óleo-resina de copaíba (C10) ( $\mathrm{g}-\mathrm{i})$. Coloração tricrômio de Gomori

Figura 26 - Imagem digitalizada de uma microplaca utilizada para a dosagem de hidroxiprolina

Figura 27 - Concentração de hidroxiprolina durante o seguimento das úlceras nos dias 2, 7 e 14, conforme os tratamentos: Solução fisiológica (Sf), Creme base (Cr) e Creme a 10\% de óleoresina de copaíba (C10)

Figura 28 - Imagem digitalizada do gel de zimografia (zimograma) representando a atividade proteolítica das MMPs durante o seguimento das úlceras nos dias 2, 7 e 14, conforme os tratamentos: Solução fisiológica (Sf), Creme base $(\mathrm{Cr})$ e Creme a $10 \%$ de óleo-resina de copaíba (C10) .................. 128

Figura 29 - Atividade das metaloproteinases 2 (a,b) e 9 (c) durante 0 seguimento das úlceras nos dias 2,7 e 14, conforme os tratamentos: Solução fisiológica (Sf), Creme base $(\mathrm{Cr})$ e Creme a $10 \%$ de óleo-resina de copaíba (C10)

Figura 30 - Representação fotográfica dos fragmentos de pele humana em cultura durante o seguimento nos dias $0,1,3,7,14$ e 21, conforme os tratamentos: Meio de cultura DMEM (a); Creme base (b); Creme a 10\% (c) e a $25 \%$ (d) de óleo-resina de copaíba; Óleo-resina puro (e)

Figura 31 - Avaliação histopatológica dos fragmentos de pele humana mantidos no meio de cultura (DMEM) nos tempos: 0 (a), 1 (b), 3 (c), 7 (d), 14 (d) e 21 dias (e). Coloração HE

Figura 32 - Curvas de crescimento para os microrganismos GramPositivos E. faecalis, S. pyogenes e S. aureus, em meio de cultura BHI

Figura 33 - Curvas de crescimento para os microrganismos GramNegativos: E. coli, em meio de cultura BHI; P. aeruginosa, em meio de cultura Caldo Nutriente 
Figura 34 - Imagem digitalizada da microplaca de cultura para a determinação da CIM para o microrganismo S. aureus ........... 138

Figura 35 - Imagem digitalizada da microplaca de cultura para a determinação da CIM para o microrganismo S. pyogenes ........ 139

Figura 36 - Imagem digitalizada da microplaca de cultura para a determinação da CIM para o microrganismo E. faecalis .......... 139

Figura 37 - Imagens digitalizadas das microplacas para a determinação da CIM para os microrganismos E. coli (a) e P. aeruginosa (b).. 140

Figura 38 - $\quad$ Imagens digitalizadas das placas de cultura de S. aureus para a determinação da CBM ......................................... 141

Figura 39 - Imagens digitalizadas das placas de cultura de S. pyogenes

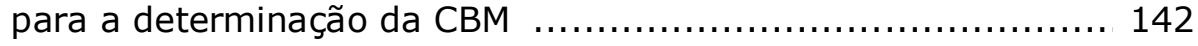

Figura 40 - Imagens digitalizadas das placas de cultura de E. faecalis para a determinação da CBM ......................................... 142

Figura 41 - Representação fotográfica do crescimento e viabilidade do microrganismo S. aureus em diferentes meios de cultura ........ 143

Figura 42 - Representação fotográfica do crescimento e viabilidade do microrganismo S. pyogenes em diferentes meios de cultura .... 144

Figura 43 - Representação fotográfica das culturas realizadas a partir de swabs colhidos 24 horas após inoculação bacteriana nas úlceras com $S$. aureus $(a-c)$ e $S$. pyogenes (d-f). Diluição das amostras 1:10. Tratamentos aplicados: Solução fisiológica (Sf) $(a, d)$, Creme base (Cr) (b, e) e Creme a $10 \%$ de óleo-

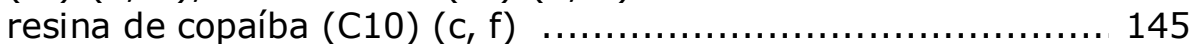

Figura 44 - $\quad$ Contagem bacteriana a partir dos exsudatos colhidos 24 horas após a inoculação bacteriana (S. aureus e $S$. pyogenes) nas úlceras tratadas com Solução fisiológica (Sf), Creme base controle (Cr) e Creme a 10\% de óleo-resina de copaíba (C10).. 146

Figura 45 - Representação fotográfica do padrão de beta-hemólise observado nas culturas realizadas a partir de swabs e biópsias das úlceras. S. aureus (a) e S. pyogenes (b) ..................... 146

Figura 46 - Contagem bacteriana em culturas realizadas a partir dos exsudatos colhidos durante o seguimento das úlceras infectadas com $S$. aureus nos dias 2, 7 e 14, conforme os tratamentos: Solução fisiológica (Sf), Creme base $(\mathrm{Cr})$ e Creme a $10 \%$ de óleo-resina de copaíba (C10)

Figura 47 - Contagem bacteriana em culturas realizadas a partir das biópsias colhidas durante o seguimento das úlceras infectadas com $S$. aureus nos dias 2, 7 e 14, conforme os tratamentos: Solução fisiológica (Sf), Creme base (Cr) e Creme a $10 \%$ de

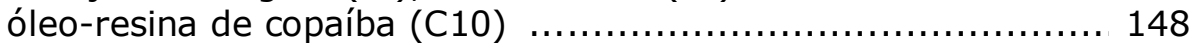


Figura 48 - Seguimento do perfil microbiológico das úlceras. Representação fotográfica das placas de cultura a partir das biópsias colhidas de úlceras infectadas com $S$. aureus, representando a diluição $1: 100$ de uma úlcera/rato por dia de avaliação, nos dias 2, 7 e 14, conforme os tratamentos: Solução fisiológica (Sf) (a-c); Creme base (Cr) (d-f); Creme a $10 \%$ de óleo-resina de copaíba (C10) (g-i)

Figura 49 - Contagem bacteriana em culturas realizadas a partir dos exsudatos colhidos durante o seguimento das úlceras infectadas com S. pyogenes nos dias 2, 7 e 14, conforme os tratamentos: Solução fisiológica (Sf), Creme base $(\mathrm{Cr})$ e Creme a $10 \%$ de óleo-resina de copaíba (C10) ................... 150

Figura 50 - Contagem bacteriana em culturas realizadas a partir das biópsias colhidas durante o seguimento das úlceras infectadas com S. pyogenes nos dias 2, 7 e 14, conforme os tratamentos: Solução fisiológica (Sf), Creme base (Cr) e Creme a $10 \%$ de óleo-resina de copaíba (C10)

Figura 51 - Seguimento do perfil microbiológico das úlceras. Representação fotográfica das placas de cultura a partir das biópsias colhidas de úlceras infectadas com $S$. pyogenes, representando a diluição $1: 100$ de uma úlcera/rato por dia de avaliação, nos dias 2, 7 e 14, conforme os tratamentos: Solução fisiológica (Sf) (a-c); Creme base (Cr) (d-f); Creme a

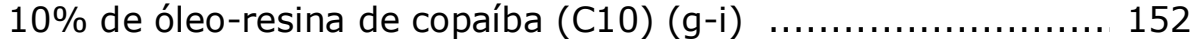

Figura 52 - Seguimento clínico das úlceras infectadas com $S$. aureus nos dias 0, 2, 7 e 14 respectivamente, conforme os tratamentos: Solução fisiológica (Sf) (a-d); Creme base (Cr) (e-h); Creme a $10 \%$ de óleo-resina de copaíba (C10) (i-I)

Figura 53 - Evolução dos índices de cicatrização das úlceras infectadas com S. aureus, nos dias 2, 7 e 14, conforme os tratamentos: Solução fisiológica (Sf), Creme base (Cr), Creme a $10 \%$ de óleo-resina de copaíba, (C10)

Figura 54 - Avaliação histopatológica das úlceras infectadas com $S$. aureus nos dias 2, 7 e 14 respectivamente, conforme os tratamentos: Solução fisiológica (Sf) $(\mathrm{a}-\mathrm{c})$; Creme base $(\mathrm{Cr})$ (d-f); Creme a $10 \%$ de óleo-resina de copaíba (C10) (g-i). Coloração hematoxilina-eosina

Figura 55 - Avaliação histopatológica das úlceras infectadas com $S$. aureus nos dias 2, 7 e 14 respectivamente, conforme os tratamentos: Solução fisiológica (Sf) $(\mathrm{a}-\mathrm{c})$; Creme base $(\mathrm{Cr})$ (d-f); Creme a $10 \%$ de óleo-resina de copaíba (C10) ( $g-i)$. Coloração tricrômio de Gomori

Figura 56 - Concentração de hidroxiprolina durante o seguimento das úlceras infectadas com $S$. aureus nos dias 2, 7 e 14, conforme os tratamentos: Solução fisiológica (Sf), Creme base ( $\mathrm{Cr}$ ) e Creme a $10 \%$ de óleo-resina de copaíba (C10) 
Figura 57 - Imagem digitalizada do gel de zimografia representando a atividade proteolítica das MMPs durante o seguimento das úlceras infectadas com $S$. aureus nos dias 2, 7 e 14 conforme os tratamentos: Solução fisiológica (Sf), Creme base $(\mathrm{Cr})$ e Creme a $10 \%$ de óleo-resina de copaíba (C10)

Figura 58 - Atividade das metaloproteinases 2 (a, b) e 9 (c) durante o seguimento das úlceras infectadas com $S$. aureus nos dias 2 , 7 e 14, conforme os tratamentos: Solução fisiológica (Sf), Creme base $(\mathrm{Cr})$ e Creme a $10 \%$ de óleo-resina de copaíba (C10)

Figura 59 - Seguimento clínico das úlceras infectadas com S. pyogenes nos dias $0,2,7$ e 14 respectivamente, conforme os tratamentos: Solução fisiológica (Sf) (a-d); Creme base $(\mathrm{Cr})$ (e-h); Creme a 10\% de óleo-resina de copaíba (C10) (i-I)

Figura 60 - Evolução dos índices de cicatrização das úlceras infectadas com S. pyogenes, nos dias 2, 7 e 14 conforme os tratamentos: Solução fisiológica (Sf), Creme base controle (Cr) e Creme a $10 \%$ de óleo-resina de copaíba (C10)

Figura 61 - Avaliação histopatológica das úlceras infectadas com $S$. pyogenes nos dias 2, 7 e 14 respectivamente, conforme os tratamentos: Solução fisiológica (Sf) $(\mathrm{a}-\mathrm{c})$; Creme base $(\mathrm{Cr})$ (d-f); Creme a $10 \%$ de óleo-resina de copaíba (C10) (g-i). Coloração hematoxilina-eosina

Figura 62 - Avaliação histopatológica das úlceras infectadas com $S$. pyogenes nos dias 2, 7 e 14 respectivamente, conforme os tratamentos: Solução fisiológica (Sf) (a-c); Creme base (Cr) (d-f); Creme a $10 \%$ de óleo-resina de copaíba (C10) (g-i). Coloração tricrômio de Gomori

Figura 63 - Concentração de hidroxiprolina durante o seguimento das úlceras infectadas com $S$. pyogenes nos dias 2, 7 e 14, conforme os tratamentos: Solução fisiológica (SF), Creme base $(\mathrm{Cr})$ e Creme a $10 \%$ de óleo-resina de copaíba (10)

Figura 64 - Imagem digitalizada do gel de zimografia representando a atividade proteolítica das MMPs durante o seguimento das úlceras infectadas com $S$. pyogenes nos dias 2, 7 e 14, conforme os tratamentos: Solução fisiológica (Sf), Creme base ( $\mathrm{Cr}$ ) e Creme a $10 \%$ de óleo-resina de copaíba (C10)

Figura 65 - Atividade das metaloproteinases 2 (a, b) e 9 (c) durante o seguimento das úlceras infectadas com $S$. pyogenes nos dias 2, 7 e 14 conforme os tratamentos: Solução fisiológica (Sf), Creme base $(\mathrm{Cr})$ e Creme a $10 \%$ de óleo-resina de copaíba (C10) 


\section{LISTA DE TABELAS}

Tabela 1 - Frequência relativa dos terpenóides detectados em amostras de óleo de copaíba $\ldots \ldots \ldots \ldots \ldots \ldots \ldots \ldots \ldots \ldots \ldots \ldots . \ldots . \ldots \ldots$

Tabela 2 - Microrganismos, meios de cultura avaliados e resultados

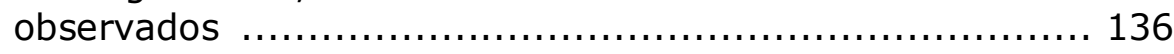




\section{LISTA DE QUADROS}

Quadro 1 - Soluções de óleo-resina de copaíba para os testes de sensibilidade bacteriana ...................................... 97

Quadro 2 - Protocolo de preparo da microplaca de cultivo para a determinação da concentração inibitória mínima do óleoresina de copaíba............................................... 99

Quadro 3 - Protocolo de preparo da microplaca de cultivo para a determinação da concentração inibitória mínima do óleoresina de copaíba ............................................... 100

Quadro 4 - Representação do protocolo experimental para a determinação da CIM, referente à figura $34 \ldots \ldots \ldots \ldots \ldots \ldots . . .138$

Quadro 5 - Representação do protocolo experimental para a determinação da CIM, referente à figura $35 \ldots \ldots \ldots \ldots \ldots \ldots . . .139$

Quadro 6 - Representação do protocolo experimental para a determinação da CIM, referente à figura $36 \ldots \ldots \ldots \ldots \ldots \ldots \ldots . .140$ 


\section{LISTA DE SIGLAS}

\begin{tabular}{|c|c|}
\hline ATCC & American Type of Culture Collection \\
\hline BHI & Brain-Heart Infusion \\
\hline BSA & Bovine serum albumine \\
\hline CETEA & Comissão de Ética em Experimentação Animal \\
\hline CBM & Concentração Bactericida Mínima \\
\hline CIM & Concentração Inibitória Mínima \\
\hline COBEA & Colégio Brasileiro de Experimentação Animal \\
\hline CPM & Contagens por minuto \\
\hline C10 & Creme a $10 \%$ de óleo-resina de copaíba \\
\hline C25 & Creme a $25 \%$ de óleo-resina de copaíba \\
\hline $\mathbf{C r}$ & Creme base \\
\hline DMEM & Dulbecco's Modified Eagle Medium \\
\hline DMSO & Dimetilsulfóxido \\
\hline EGF & Endothelial Growth Factor \\
\hline EUA & Estados Unidos da América \\
\hline FDA & Food and Drug Administration \\
\hline FGF & Fibroblast Growth Factor \\
\hline FMRP & Faculdade de Medicina de Ribeirão Preto \\
\hline HCRP & Hospital das Clínicas de Ribeirão Preto \\
\hline $\mathrm{HCl}$ & Ácido clorídrico \\
\hline HE & hematoxilina-eosina \\
\hline hOSEC & human Organotypic Skin Explant Culture \\
\hline ICU & Índice de Cicatrização das Úlceras \\
\hline IL-1 & Interleucina-1 \\
\hline IL-6 & Interleucina- 6 \\
\hline iNOS & induced Nitric Oxide \\
\hline KGF & Keratinocyte Growth Factor \\
\hline MEC & Matriz Extracelular \\
\hline MH & Mueller-Hinton \\
\hline MHa & Mueller-Hinton ágar \\
\hline
\end{tabular}




\begin{tabular}{|c|c|}
\hline MHb & Mueller-Hinton broth \\
\hline MMP & Matrix Metalloproteinase \\
\hline MTT & 3-[4,5-dimetiltiazol-2-il]-2,5-difenil-brometo de tetrazólio \\
\hline NGF & Neural Growth Factor \\
\hline NIH & National Institutes of Health \\
\hline OMS & Organização Mundial de Saúde \\
\hline OR & Óleo-resina de copaíba \\
\hline PBS & Phosphate Buffered Saline \\
\hline PDEE & Programa de Doutorado no País com Estágio no Exterior \\
\hline PDGF & Platelet-Derived Growth Factor \\
\hline pH & Potencial Hidrogeniônico \\
\hline $\mathbf{P M N}$ & Polimorfonucleares \\
\hline qsp & quantidade suficiente para \\
\hline RNA & Ribonucleic Acid \\
\hline RPMI & Roswell Park Memorial Institute (meio de cultura) \\
\hline SDS & Sodium Dodecyl Sulfate \\
\hline SDS-PAGE & Sodium Dodecyl Sulfate Polyacrylamide Gel Electrophoresis \\
\hline Sf & Solução fisiológica \\
\hline TG & tricrômio de Gomori \\
\hline TGF-a & Transforming Growth Factor-alfa \\
\hline TGF- $\beta$ & Transforming Growth Factor-beta \\
\hline TIMPs & Tissue Inhibitors of Metalloproteinases \\
\hline TNF & Tumor Necrosis Factor \\
\hline TSA & Tryptic Soy Agar \\
\hline TSB & Tryptic Soy Broth \\
\hline UFC & Unidade Formadora de Colônia \\
\hline UWM & University of Wisconsin - Milwaukee \\
\hline USP & Universidade de São Paulo \\
\hline VEGF & Vascular Endothelial Growth Factor \\
\hline
\end{tabular}




\section{SUMÁRIO}

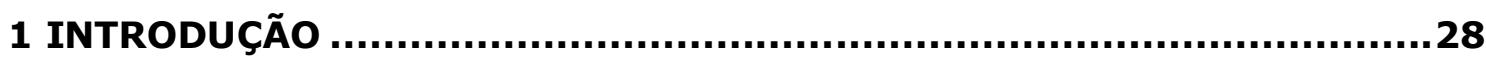

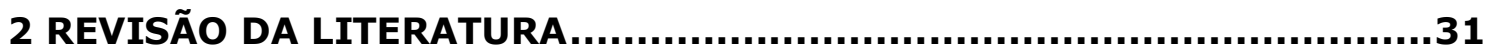

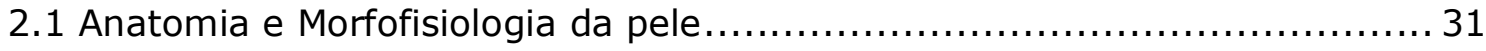

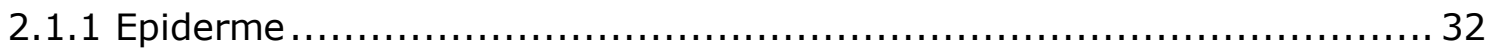

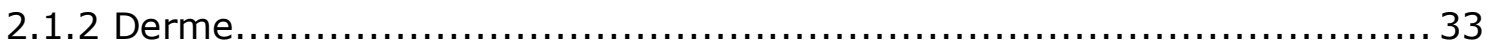

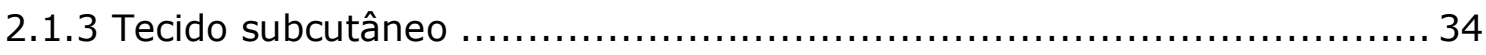

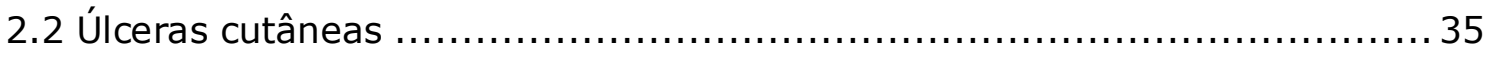

2.2.1 Úlceras cutâneas agudas e Úlceras cutâneas crônicas...................... 37

2.2.2 Etiologia e Epidemiologia............................................ 39

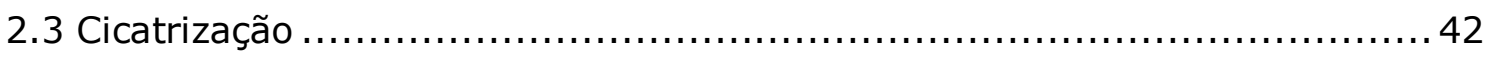

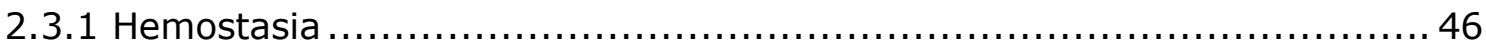

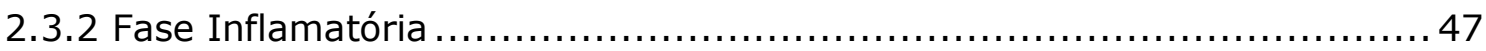

2.3.3 Fase de Proliferação Tecidual ........................................... 49

2.3.4 Fase de Remodelamento Tecidual ....................................... 53

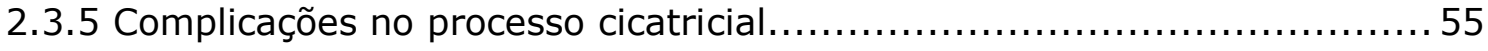

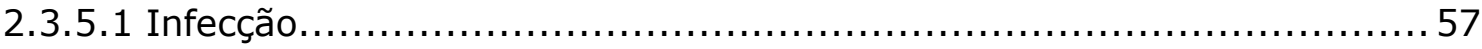

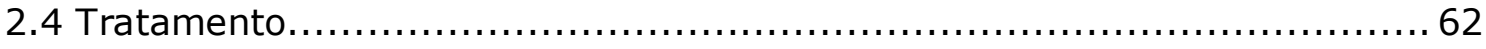

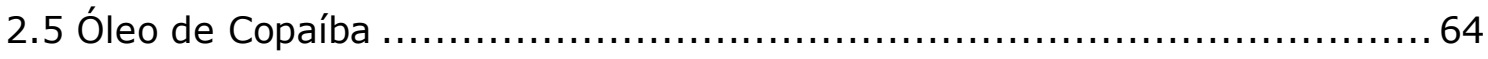

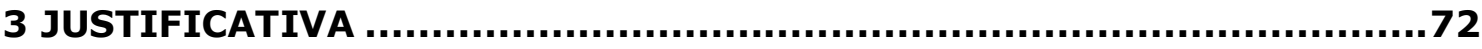

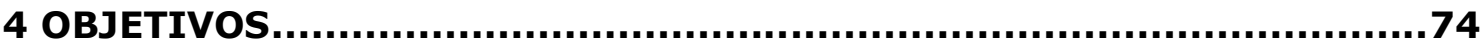

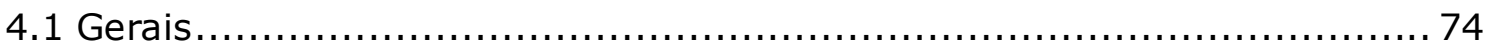

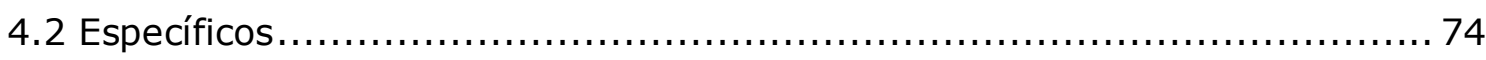

5 MATERIAL E MÉTODOS ............................................................ 77

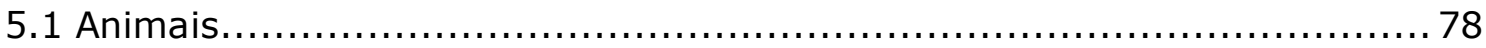

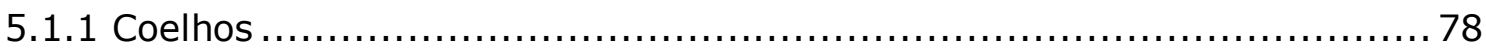

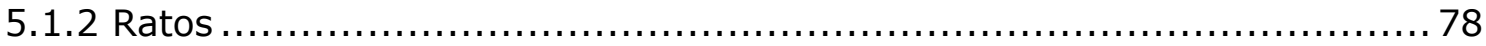

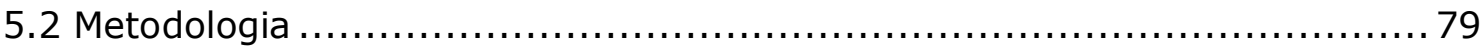

5.2.1 ESTUDO 1: Avaliação da citotoxicidade do óleo-resina de copaíba em

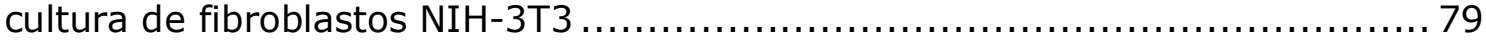

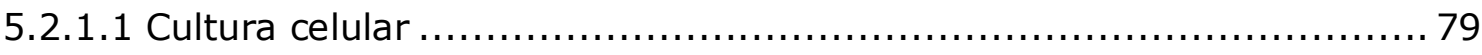

5.2.1.2 Avaliação da Viabilidade Celular ...................................... 79 
5.2.1.3 Avaliação da Proliferação Celular.

5.2.2 ESTUDO 2: Avaliação do potencial cicatrizante do óleo-resina de copaíba em úlceras cutâneas no modelo de orelha de coelho $\ldots \ldots \ldots \ldots \ldots \ldots \ldots \ldots . \ldots 1$

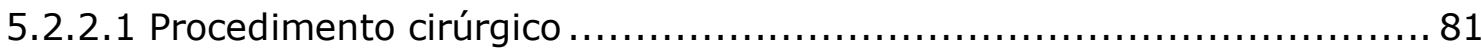

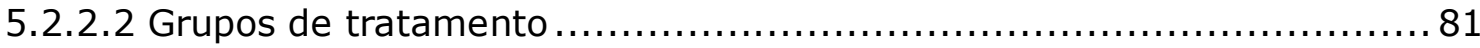

5.2.2.3 Seguimento clínico-experimental: Captura e Análise de imagem .........82

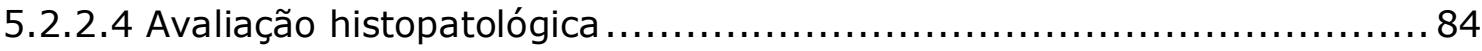

5.2.3 ESTUDO 3: Avaliação do potencial cicatrizante do óleo-resina de copaíba em úlceras cutâneas em ratos......................................... 84

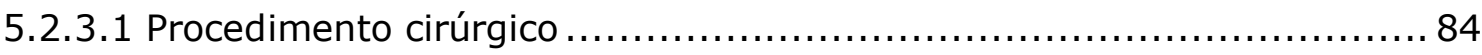

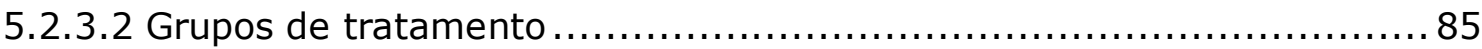

5.2.3.3 Seguimento clínico-experimental: Captura e Análise de imagem .........85 85

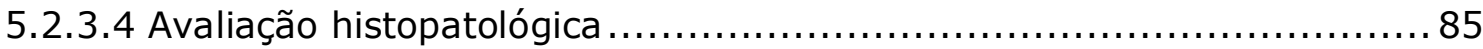

5.2.3.5 Avaliação Bioquímica: Dosagem de Hidroxiprolina........................ 86

5.2.3.6 Avaliação Bioquímica: Dosagem de Metaloproteinases ................... 87

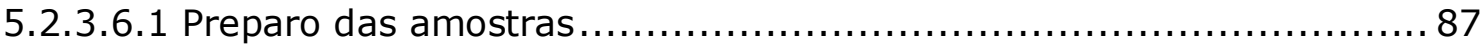

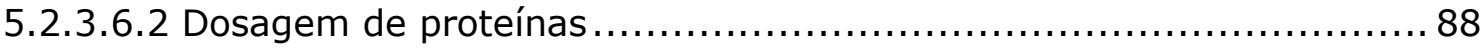

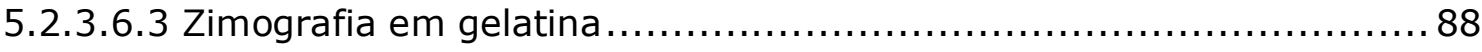

5.2.4 ESTUDO 4: Efeito do óleo-resina de copaíba no modelo ex vivo de cicatrização da pele humana (culturas organotípicas de explantes de pele

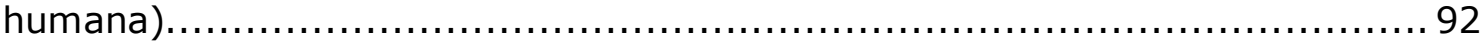

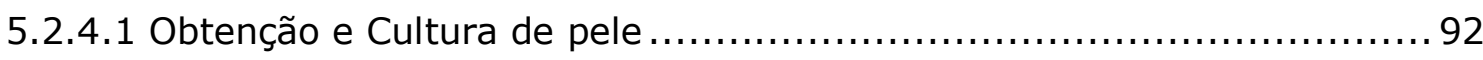

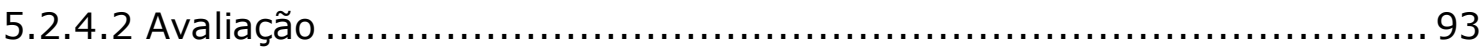

5.2.5 ESTUDO 5: Avaliação da atividade antimicrobiana in vitro do óleoresina de copaíba. .............................................................. 93

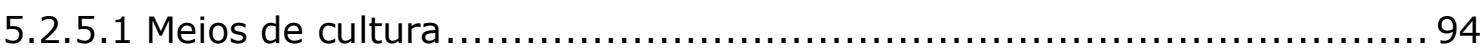

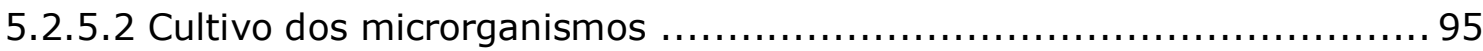

5.2.5.3 Determinação da curva de crescimento bacteriano..................... 96

5.2.5.4 Determinação da Concentração Inibitória Mínima (CIM) .................. 96

5.2.5.4.1 Preparo das soluções estoque de óleo-resina de copaíba ............... 96

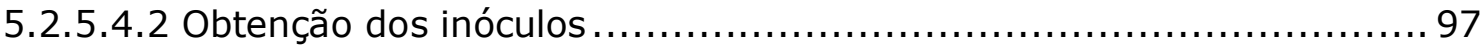

5.2.5.4.3 Microdiluições e subcultura dos microrganismos........................ 98

5.2.5.5 Determinação da Concentração Bactericida Mínima (CBM).............. 102

5.2.6 ESTUDO 6: Avaliação da atividade antimicrobiana in vivo do óleo-resina de copaíba em úlceras cutâneas infectadas em ratos........................... 102

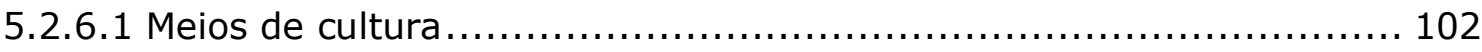

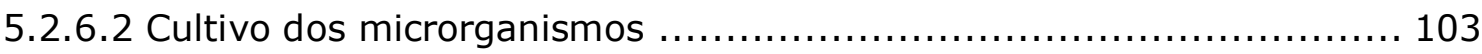

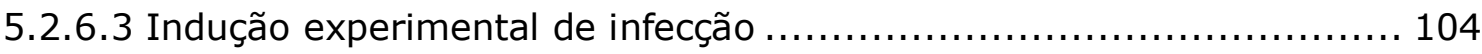


5.2.6.4 Grupos de tratamento ................................................... 105

5.2.6.5 Avaliação da atividade antimicrobiana.................................. 105

5.2.6.5.1 Avaliação inicial do perfil microbiológico das úlceras ................... 106

5.2.6.5.2 Seguimento do perfil microbiológico das úlceras ..................... 107

5.2.7 ESTUDO 7: Avaliação do potencial cicatrizante do óleo-resina de copaíba em úlceras cutâneas infectadas em ratos.................................. 109

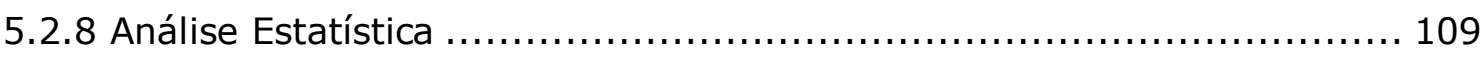

6 RESULTADOS..........................................................................111

6.1 ESTUDO 1: Avaliação da citotoxicidade do óleo-resina de copaíba em cultura de fibroblastos NIH-3T3 ............................................... 111

6.1 .1 Avaliação da viabilidade celular ............................................. 111

6.1.2 Avaliação da proliferação celular............................................ 113

6.2 ESTUDO 2: Avaliação do potencial cicatrizante do óleo-resina de copaíba em úlceras cutâneas no modelo de orelha de coelho .............................. 114

6.2.1 Seguimento clínico-experimental .......................................... 114

6.2.2 Índice de Cicatrização das Úlceras (ICU) ................................ 117

6.2 .3 Avaliação histopatológica..................................................... 118

6.3 ESTUDO 3: Avaliação do potencial cicatrizante do óleo-resina de copaíba

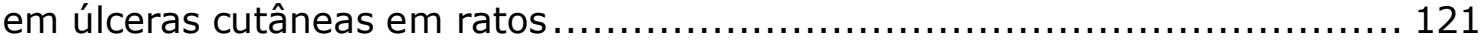

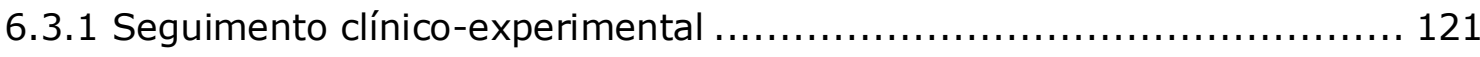

6.3.2 Índice de Cicatrização das Úlceras (ICU) .................................... 122

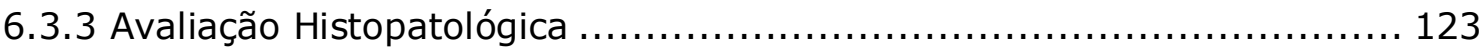

6.3.4 Avaliação Bioquímica: Dosagem de Hidroxiprolina ........................ 125

6.3.5 Avaliação Bioquímica: Dosagem de Metaloproteinases...................... 127

6.4 ESTUDO 4: Efeito do óleo-resina de copaíba no modelo ex vivo de cicatrização da pele humana (culturas organotípicas de explantes de pele

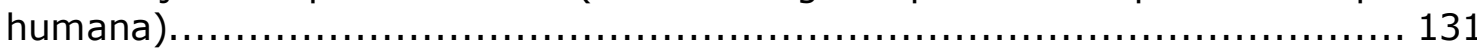

6.5 ESTUDO 5: Avaliação da atividade antimicrobiana in vitro do óleo-resina

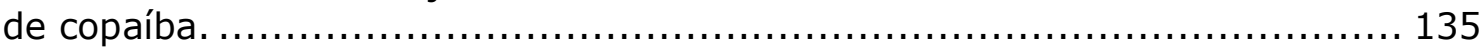

6.5.1 Padronização do cultivo e curva de crescimento bacteriano ................ 135

6.5.2 Determinação da Concentração Inibitória Mínima (CIM) .................... 137

6.5.3 Determinação da Concentração Bactericida Mínima (CBM) ................. 140

6.6 ESTUDO 6: Avaliação da atividade antimicrobiana in vivo do óleo-resina de copaíba em úlceras cutâneas infectadas em ratos............................. 143

6.6.1 Avaliação inicial do perfil microbiológico das úlceras ....................... 144

6.6.2 Atividade antimicrobiana in vivo do óleo-resina de copaíba em úlceras cutâneas infectadas com Staphylococcus aureus ................................ 147 
6.6.2.1 Seguimento do perfil microbiológico das úlceras pela contagem

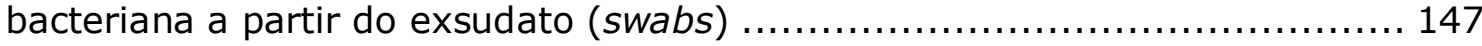

6.6.2.2 Seguimento do perfil microbiológico das úlceras pela contagem

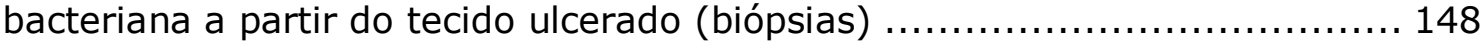

6.6.3 Atividade antimicrobiana in vivo do óleo-resina de copaíba em úlceras cutâneas infectadas com Streptococcus pyogenes

6.6.3.1 Seguimento do perfil microbiológico das úlceras pela contagem bacteriana a partir do exsudato (swabs)

6.6.3.2 Seguimento do perfil microbiológico das úlceras pela contagem bacteriana a partir do tecido ulcerado (biópsias)

6.7 ESTUDO 7: Avaliação do potencial cicatrizante do óleo-resina de copaíba

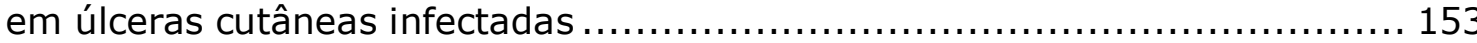

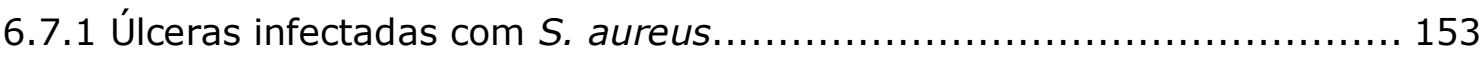

6.7.1.1 Seguimento clínico-experimental ................................. 153

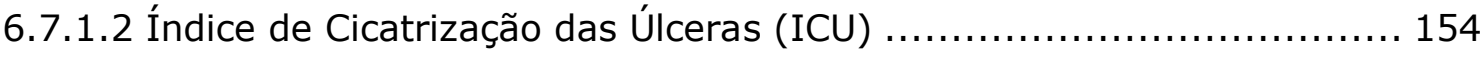

6.7.1.3 Avaliação Histopatológica......................................... 155

6.7.1.4 Avaliação Bioquímica: Dosagem de Hidroxiprolina...................... 157

6.7.1.5 Avaliação Bioquímica: Dosagem de Metaloproteinases .................. 158

6.7.2 Úlceras infectadas com S. pyogenes...................................... 161

6.7.2.1 Seguimento clínico-experimental ...................................... 161

6.7.2.2 Índices de Cicatrização das Úlceras (ICU) ............................ 162

6.7.2.3 Avaliação Histopatológica.................................................... 163

6.7.2.4 Avaliação Bioquímica: Dosagem de Hidroxiprolina..................... 165

6.7.2.5 Avaliação Bioquímica: Dosagem de Metaloproteinases................. 166

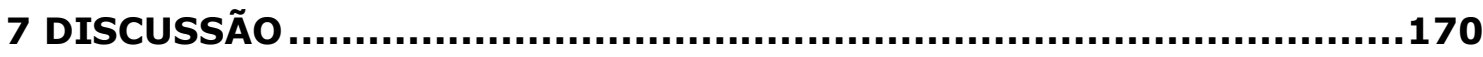

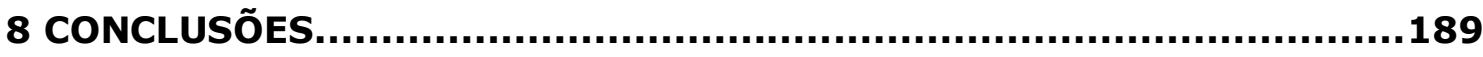

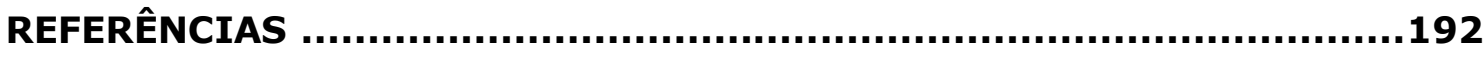

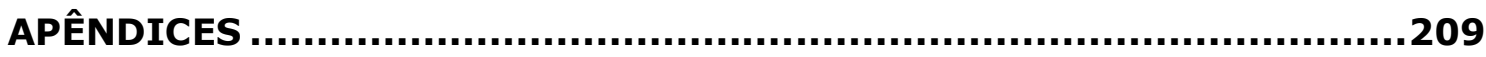

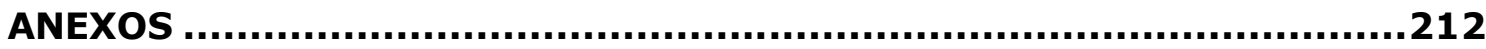




\section{Introdução}

"Uma longa viagem começa com um único passo".

Lao-Tsé 


\section{INTRODUÇÃO}

O reparo tecidual é um processo biológico complexo e multifatorial que, didaticamente, pode ser dividido em quatro fases sequenciais, porém sobrepostas: hemostasia, inflamação, proliferação e remodelamento tecidual (DOUGHTY; SPARKS-DeFRIESE, 2012; JAUL, 2009; STOJADINOVIC et al., 2008). Após uma lesão, vários caminhos intra e intercelulares devem ser ativados e coordenados para restaurar a homeostasia e a integridade do tecido.

Componentes celulares do sistema imune, da cascata da coagulação e da inflamação são ativados e células como neutrófilos, macrófagos, células endoteliais, queratinócitos e fibroblastos, passam por modificações importantes levando à proliferação, diferenciação e migração celular (GURTNER et al., 2008). Citocinas, fatores de crescimento, proteinases e moléculas de adesão orquestram as interações celulares e aquelas com componentes da matriz extracelular do tecido, contribuindo durante todas as fases da cicatrização (BAKER et al., 2008).

A exposição do tecido subcutâneo após a perda da integridade cutânea resulta na formação de um ambiente úmido, quente e nutritivo, que pode favorecer a proliferação microbiana (BOWLER; DUERDEN; ARMSTRONG, 2001). Dentre as bactérias frequentemente isoladas a partir de úlceras venosas crônicas, encontram-se os gêneros Staphylococcus, Streptococcus, Enterococcus e bacilos Gram-negativos (DAVIES et al., 2007; STEPHENS et al., 2003). Interações microbianas podem influenciar a patogênese e a cicatrização da úlcera, levando à sua cronicidade, assim como contribuir para a resistência bacteriana à antibioticoterapia. Bactérias colonizantes no leito da úlcera podem levar à infecção ativa com subsequente interferência no processo cicatricial (SHAI; MAIBACH, 2005).

Dentre as alternativas para o tratamento de úlceras cutâneas, muitas plantas medicinais têm demonstrado potencial terapêutico e dentre as inúmeras espécies vegetais de interesse medicinal, estão as plantas do gênero Copaifera spp. Estudos fitoquímicos do óleo-resina da Copaifera langsdorffii demonstraram a presença da mistura de diterpenos e sesquiterpenos, responsáveis pelas atividades biológicas (PAIVA et al., 2002; SANTOS et al., 2008a, b). O óleoresina obtido de várias espécies de Copaifera é usado popularmente principalmente como antiinflamatório e cicatrizante (CARVALHO et al., 2005). 
São descritas ainda propriedades gastroprotetoras, analgésicas, repelente de insetos, antimicrobianas entre outras (BRANDÃO et al., 2008; GOMES et al., 2007; PIERI et al., 2009; SANTOS et al., 2008b).

A incidência de úlceras cutâneas crônicas ainda se mantém alta, mesmo com os grandes avanços na compreensão do processo cicatricial, tornando-se relevante a busca de novas possibilidades terapêuticas. Desta forma, nesse estudo buscou-se avaliar os possíveis mecanismos de ação do óleo-resina de copaíba na cicatrização de úlceras cutâneas, assim como sua toxicidade e atividade antimicrobiana in vitro e in vivo, antecedendo sua aplicação e concentrações seguras para o uso na prática clínica. 
Revisão da Literatura

"Se pude enxergar mais longe, foi porque me apoiei em ombros de gigantes". Isaac Newton 


\section{REVISÃO DA LITERATURA}

\subsection{Anatomia e Morfofisiologia da pele}

A pele é o maior órgão do corpo humano e juntamente com os seus apêndices (pêlos, glândulas sudoríparas e sebáceas) constitui um órgão complexo responsável por funções essenciais nos mecanismos homeostáticos, incluindo proteção contra agressões do meio externo, manutenção do equilíbrio hídrico, termo-regulação, absorção, resposta imunológica, detecção sensorial, cicatrização entre outras (BARTHEL; ABERDAM, 2005; CLARK et al., 2007).

Nos adultos, dependendo do peso e da altura do indivíduo, a superfície cutânea varia de 1,5 a 2,0 $\mathrm{m}^{2}$ e o peso entre 5 e $10 \mathrm{Kg}$, o que corresponde a $7 \%$ do peso corporal total. A pele varia em espessura (de 0,5 $\mathrm{mm}$ na membrana timpânica a 6,0 mm na sola dos pés e palma das mãos), grau de pigmentação e quantidade de pêlos (BARTHEL; ABERDAM, 2005; EDWARDS, 2005; WYSOCKI, 2012), e é composta por três camadas distintas: Epiderme, Derme e Tecido celular subcutâneo (Figura 1).

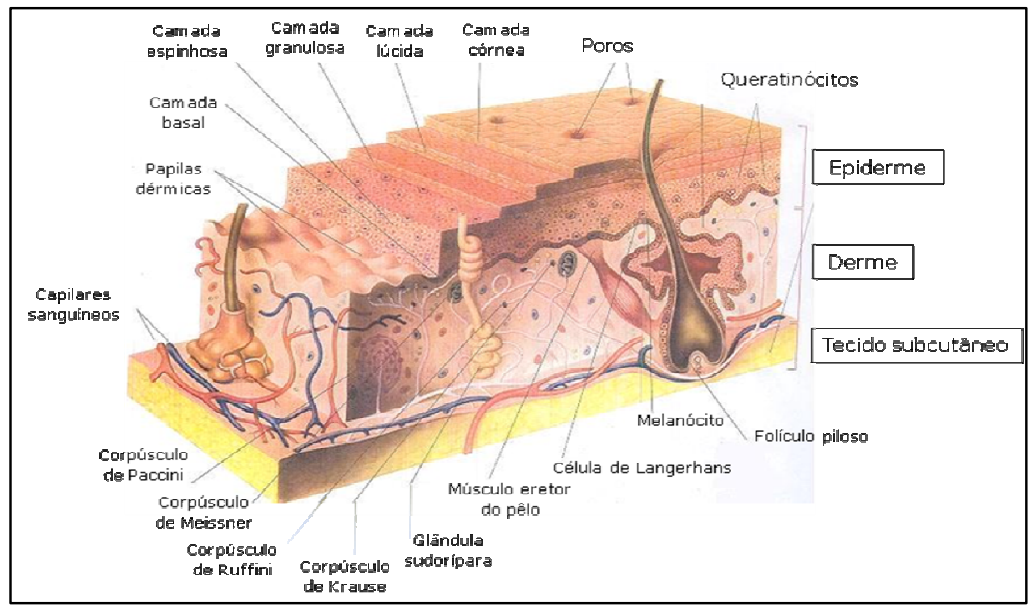

Figura 1 - Estrutura microscópica da pele (Adaptada de MARTIN, 2005). 


\subsubsection{Epiderme}

Estruturalmente, a epiderme e a derme formam duas camadas distintas, embora funcionem como uma única camada. A epiderme é composta de células epiteliais e forma a camada protetora externa, não contém vasos sanguíneos ou terminações nervosas, e recebe nutrientes por difusão a partir dos vasos sanguíneos presentes na derme. Histologicamente, a epiderme é um epitélio escamoso estratificado e queratinizado apoiado na membrana basal, que a separa da derme. Usualmente é constituída de cinco camadas celulares, com células sendo produzidas na camada basal (mais profunda) e movendo-se através das outras camadas em direção à camada córnea (superficial) em um período de aproximadamente 35 dias (ABRAHAMS; CRAVEN; LUMLEY, 2005; EDWARDS, 2005). As células basais são mitoticamente ativas, mas perdem este potencial à medida que migram em direção à superfície cutânea no processo de diferenciação terminal (BARTHEL; ABERDAM, 2005).

A camada basal ou estrato basal é uma camada única de células com formato cúbico, localizadas em contato com a derme (junção dermo-epidérmica), e é também denominada camada germinativa ou estrato germinativo. As células da camada basal se aprofundam na derme para circundar as glândulas sudoríparas e folículos pilosos. As células basais se dividem para formar os queratinócitos, os quais são morfologicamente e bioquimicamente modificados durante o processo de queratinização ou diferenciação epidérmica. Este processo progride através das outras camadas da epiderme até a camada córnea (EDWARDS, 2005; REHDER et al., 2004).

A camada espinhosa ou estrato espinhoso localiza-se acima da camada basal e é mais espessa, contendo várias camadas de células com formato poligonal, interligadas por projeções tipo "espinhos", as quais, histologicamente, aparecem como linhas entre as células e são denominadas desmossomos, os quais promovem adesão intercelular e resistência a forcas mecânicas (EDWARDS, 2005; HABIF, 1996; WYSOCKI, 2012).

A camada granulosa ou estrato granuloso consiste de células que contêm grânulos citoplasmáticos preenchidos com ceratohialina, um precursor da queratina que contribui para a sua agregação. As células contêm um glicolipídeo 
hidrofóbico que é secretado no espaço extracelular e diminui a perda de água transepidérmica (EDWARDS, 2005).

A camada lúcida está presente somente em áreas onde a epiderme é mais espessa, como na palma das mãos e na sola dos pés. As células desta camada começam a sofrer degeneração nuclear e contêm eleidina, uma substância gelatinosa, também precursora de queratina (EDWARDS, 2005). O núcleo, as organelas e membranas celulares não são visíveis nestas células, desta forma, histologicamente esta camada aparece transparente ou clara (GRAAF; FOX, 1989; WYSOCKI, 2012).

A camada córnea ou estrato córneo forma a camada superficial de células, que estão mortas e são preenchidas por queratina (corneócitos), as quais estão constantemente sendo removidas da superfície corporal pelo processo de descamação ou esfoliação. Esta camada de células achatadas e anucleadas proporciona uma superfície resistente, protegendo as células presentes nas camadas mais profundas (EDWARDS, 2005).

A epiderme contém células especializadas como os queratinócitos (responsáveis pela renovação epidérmica e proteção), melanócitos (responsáveis pela pigmentação da pele e síntese de melanina, que é progressivamente transferida aos queratinócitos), células de Langerhans e células de Merkkel (EDWARDS, 2005; HABIF, 1996; SOUTO et al., 2006).

\subsubsection{Derme}

A derme é uma camada de tecido conjuntivo vascular de origem mesenquimal firmemente ligada à epiderme, em sua porção superior, e ao tecido subcutâneo, em sua porção mais profunda. Na derme estão os vasos sanguíneos e linfáticos, terminações nervosas, ductos sudoríparos, glândulas sebáceas alveolares e músculos eretores do pêlo, ligados aos folículos pilosos. As raízes dos pêlos e das glândulas sebáceas prolongam-se até o tecido subcutâneo. É uma camada elástica e fornece nutrição para a epiderme e para os apêndices cutâneos (ABRAHAMS; CRAVEN; LUMLEY, 2005; EDWARDS, 2005; HABIF, 1996; REHDER et al., 2004). 
É constituída por duas camadas distintas, a camada papilar (superior) e a camada reticular (inferior). A camada papilar ou derme papilar localiza-se próxima à epiderme e forma uma série de ondulações denominadas papilas dérmicas, as quais se alternam com a epiderme (EDWARDS, 2005); é a camada mais fina representando cerca de $1 / 5$ da derme e é composta de fibras de colágeno dispostas aleatoriamente (HABIF, 1996). A camada reticular ou derme reticular se estende da base da camada papilar ao tecido subcutâneo e é composta por fibras espessas de colágeno, que são organizadas paralelamente à superfície da pele e é mais espessa que a derme papilar (EDWARDS, 2005; HABIF, 1996). Não observa-se delimitação definida entre derme papilar e reticular uma vez que a mudança em tamanho que ocorre nas fibras de colágeno, ocorre de forma gradual entre as duas camadas (WYSOCKI, 2012).

Como todos os tecidos conjuntivos, a derme é formada por uma substância de fundo ou matriz (composta por ácido hialurônico, mucopolissacarídeos e condroitina-sulfato), fibras (colágenas, reticulares e elásticas) e células (fibroblastos, macrófagos, mastócitos e células transitórias) (HABIF, 1996). Os fibroblastos estão localizados entre os feixes de colágeno e sintetizam colágeno e elastina, as principais proteínas presentes na derme e a presença e o padrão de distribuição destas asseguram a consistência física da pele (textura e elasticidade) (EDWARDS, 2005; SOUTO et al., 2006).

Os macrófagos, células fagocíticas derivadas de monócitos da corrente sanguínea com função protetora, por fagocitar partículas estranhas e/ou vírus e bactérias que possam ter penetrado a epiderme; os mastócitos, que produzem histamina, prostaglandinas e outros mediadores inflamatórios; e ainda células transitórias como neutrófilos, linfócitos e monócitos, encontrados na circulação sanguínea extravasam para o tecido quando ocorre reação inflamatória em resposta a trauma ou infecção (EDWARDS, 2005).

\subsubsection{Tecido subcutâneo}

O tecido subcutâneo é o tecido mais profundo da pele e é formado principalmente por tecido adiposo; ancora a pele aos músculos e se espessa quando o indivíduo ganha peso. Constitui uma fonte de triglicerídeos para o 
corpo e consequentemente é uma fonte de energia; $60 \%$ da gordura corporal é subcutânea. As funções desta camada incluem prevenção da perda calor pelo corpo e proteção dos órgãos internos (EDWARDS, 2005).

A perda da integridade da pele pode resultar em desequilíbrio fisiológico substancial que pode ocasionar desabilidade significante ao paciente ou mesmo óbito (CLARK et al., 2007). Quando ocorre uma lesão, a pele passa por reparo, com proliferação e crescimento de células remanescentes da derme (fibroblastos e outras células estromais) e/ou epiderme (queratinócitos) (SOUTO et al., 2006).

\section{2 Úlceras cutâneas}

Úlceras cutâneas são definidas como um rompimento da continuidade anatômica da pele (envolvendo derme e/ou epiderme) e de sua funcionalidade (DIEGELMANN; EVANS, 2004; KOKANE, 2009; SCHMIDT et al., 2009).

Várias doenças de base como insuficiência vascular arterial e venosa, insuficiência nutricional, perda de mobilidade, imunodeficiência e exacerbação de comorbidades como diabetes, insuficiência cardíaca e infecção, prejudicam a integridade cutânea tornando propício o desenvolvimento de úlceras. Uma vez que a pele é rompida, a lesão pode progredir rapidamente a úlcera profunda e extensa (JAUL, 2009).

É possível evidenciar antigas orientações por meio de registros que coincidem com a existência do homem no mundo, demonstrando que há muito tempo reconhece-se a importância de proteger as lesões cutâneas de forma a evitar complicações ao paciente. Nos últimos séculos e nas décadas recentes inúmeros avanços trouxeram mudanças significantes no conhecimento científico sobre o processo cicatricial, que influenciaram as abordagens atualmente aceitas no tratamento de úlceras cutâneas (SHAI; MAIBACH, 2005).

O conceito de manter a úlcera limpa e coberta é extremamente antigo. Relatos de cuidados a úlceras são datados de 2100 a.C., quando três procedimentos para promover a cicatrização foram instituídos à famosa placa de argila sumeriana: lavar a lesão com cerveja e água quente, fazer emplastros (mistura de ervas, pomadas e óleos) e cobrir a úlcera (BROUGHTON II; JANIS; ATTINGER, 2006a). 
De 1550 a.C. a aproximadamente 377 a.C., recomendava-se a aplicação de substâncias como o mel, óleos, ervas medicinais e graxa nas úlceras cutâneas em forma de pasta para remover tecido não-viável e pus, estimulando a cicatrização. Existem relatos que descrevem o tratamento como bactericida, uma vez que a mistura de um terço de mel e dois terços de óleo diminuía a contagem de Staphylococcus aureus a menos de $10^{5}$ unidades formadoras de colônia (UFC) e a menos de $10^{2}$ UFC de Escherichia coli dentro de 24 horas. O tratamento de úlceras desta forma é documentado em papiros datados de 1400 a.C (BROUGHTON II; JANIS; ATTINGER, 2006a); por volta de 100 d.C., preconizavase a limpeza e a remoção de corpos estranhos antes do fechamento primário das lesões por meio de sutura (SHAI; MAIBACH, 2005).

Os avanços limitados continuaram através da Idade Média e Renascença; do século XIX advieram os avanços tecnológicos e clínicos com os procedimentos cirúrgicos estéreis. Entre o final de 1840 e a Segunda Guerra Mundial, o foco para o tratamento de úlceras e cicatrização foi a utilização de anti-sépticos e antimicrobianos, e, baseado na crença de que o ambiente seco proporcionava melhores condições de cicatrização, a proteção das úlceras era realizada com coberturas secas (MANDELBAUM; DI SANTIS; MANDELBAUM, 2003).

Em 1891, Johnson \& Johnson foi a primeira empresa a produzir curativos cirúrgicos estéreis em massa, através da esterilização de algodão e gaze com calor seco e então por vapor e pressão (BROUGHTON II; JANIS; ATTINGER, 2006a).

Em 1908, Ilya Metchnikoff recebeu o prêmio Nobel por sua descoberta da fagocitose e a teoria que o objetivo da inflamação era trazer células fagocíticas para a área lesada para destruir bactérias. Em 1926, foi publicado que macrófagos originavam-se de monócitos migratórios e modificados no tecido. Também relatou-se que células endoteliais lesadas iriam se alongar e se diferenciar na úlcera em "fibroblastos" (o que foi descrito, entretanto não sabiase, é que era angiogênese). Citocinas e fatores de crescimento como pirógeno endógeno (conhecido atualmente como interleucina-1), fator de crescimento neural (NGF) e interferon, foram descritos primeiramente nos anos 50. Em 1959, foi descrito o fator de crescimento endotelial (EGF). Nos anos 60, imunologistas descreveram mediadores produzidos por linfócitos que afetavam a função imune, denominados linfocinas. Em 1962 demonstrou-se que ocluindo a úlcera (com consequente retenção de umidade), a taxa de epitelização das lesões era mais 
rápida comparada a lesões expostas ao ar, e ainda, a formação de crostas era minimizada (CHOUCAIR; BELLO; PHILLIPS, 2003; MANDELBAUM; DI SANTIS; MANDELBAUM, 2003).

No início dos anos 70, as atividades do fator de necrose tumoral (TNF) foram publicadas. No final dos anos 80 e 90, vários mediadores inflamatórios foram identificados e caracterizados como interleucinas, citocinas, quimiocinas e fatores de crescimento (BROUGHTON II; JANIS; ATTINGER, 2006a).

Muitos recursos naturais e sintéticos têm sido alvos frequentes na busca de estratégias eficazes da estimulação do processo cicatricial e dezenas de curativos impregnados com diferentes substâncias, desde vaselina a fatores de crescimento geneticamente produzidos, estão disponíveis comercialmente (BROUGHTON II; JANIS; ATTINGER, 2006a).

\subsection{1 Úlceras cutâneas agudas e Úlceras cutâneas crônicas}

As úlceras cutâneas podem ser classificadas como agudas, as quais cicatrizam de forma ordenada e em tempo necessário para que haja a restauração da integridade anatômica e funcional da pele, ou úlceras crônicas, que falham em progredir para as fases normais subsequentes do processo cicatricial (BELLO; PHILLIPS, 2000; MENKE et al., 2007). Como resultado, o processo é retardado, incompleto e não progride de maneira ordenada, ocasionando resultados anatômicos e funcionais insatisfatórios. Úlceras crônicas geralmente causam inabilidades físicas aos pacientes e são caracterizadas por recidivas frequentes (MENKE et al., 2007; ROLDÁN-MARÍN et al., 2009).

Úlceras agudas geralmente têm origem traumática ou cirúrgica, enquanto as úlceras crônicas são frequentemente causadas por comprometimento vascular, inflamação crônica ou agressões repetitivas ao tecido (DOUGHTY; SPARKS-DeFRIESE, 2012).

Os tipos mais comuns de úlceras crônicas incluem úlceras venosas, arteriais, neuropáticas e úlceras por pressão (BELLO; PHILLIPS, 2000).

Embora o período de tempo não esteja claramente definido pela literatura, são consideradas úlceras crônicas aquelas cuja cicatrização não ocorreu dentro do tempo esperado, superior a 6 semanas (ROLDÁN-MARÍN et 
al., 2009) ou 3 a 4 meses (SHAI; MAIBACH, 2005). O tempo para uma úlcera crônica reepitelizar completamente é significantemente maior e em alguns casos, a úlcera tem sua área aumentada, principalmente devido ao ambiente altamente rico em proteases (MENKE et al., 2007).

As úlceras crônicas se caracterizam por apresentarem inflamação exacerbada devido a presença de infecção bacteriana ou corpos estranhos que não podem ser solubilizados ou fagocitados (KLOTH; MCCULLOCH, 1995), aumento da atividade enzimática das proteases, redução da resposta aos fatores de crescimento ou se tornam crônicas pela senescência celular (JUDE et al 2002; KONIG; PESCHEN; LAUER et al, 2000; MENKE et al., 2008; RAO et al, 1995; SCHULTZ, 2012). Figura 2.

\begin{tabular}{|lll|l|}
\hline \multicolumn{2}{|c|}{ Úlceras Agudas } & $\checkmark$ B́lceras Crônicas \\
$\checkmark$ & Alta atividade mitogênica & $\checkmark$ Senescência prematura \\
$\checkmark$ & Fibroblastos normais & $\checkmark$ Excesso de MMP \\
$\checkmark$ Proporção normal MMP-TIMP & $\checkmark$ Alto nível \\
$\checkmark$ Citocinas pró-inflamatórias (baixo nível) & $\checkmark$ Atividade reduzida \\
$\checkmark$ Fatores de crescimento (atividade normal) & $\checkmark$ Degradação de MEC \\
$\checkmark$ Deposição de MEC & $\checkmark$ Inflamação descontrolada \\
$\checkmark$ Inflamação auto-limitada & $\checkmark$ Tempo prolongado \\
$\checkmark$ Tempo normal para a cicatrização & $\checkmark$ Altos níveis de bactéria \\
$\checkmark$ Quantidade reduzida de bactérias & \\
\hline
\end{tabular}

Figura 2 - Desequilíbrio na cicatrização, caracterização de úlceras agudas e crônicas. Adaptado de MENKE et al., 2007; SHAI; MAIBACH, 2005 e SCHULTZ, 2012.

O estado inflamatório persistente retarda ou impede a cicatrização. O estimulo pró-inflamatório é multifatorial por sua natureza, relacionado à hipóxia local, trauma repetitivo do tecido, injúria por isquemia-reperfusão, necrose, assim como pela carga bacteriana. Alto nível de atividade mitogênica, que é normalmente evidente em úlceras agudas, está ausente nas úlceras crônicas. 0 equilíbrio delicado entre citocinas pró-inflamatórias, quimiocinas, proteases e 
seus inibidores naturais [metaloproteinases de matriz (MMP)/inibidores teciduais de metaloproteinases (TIMPs)] das úlceras agudas está alterado nas úlceras crônicas. Neutrófilos residentes e macrófagos ativados nas úlceras crônicas secretam citocinas pró-inflamatórias [fator de necrose tumoral alfa (TNF-a), interleucina-1 beta (IL-1ß)] que aumentam a produção de MMP e reduzem a síntese de TIMP, o que resulta na degradação da matriz extracelular (MEC), prejudicando a migração celular, reduzindo a proliferação de fibroblastos e diminuindo a síntese colagênica. Esta inflamação sustentada e o ambiente proteolítico prejudicam o progresso para a fase proliferativa do processo cicatricial. Quando combinada com dano celular e resposta sistêmica do paciente, esta situação de desequilíbrio estabelece um ciclo fisiopatológico deletério que perpetua a não-cicatrização da úlcera (BELLO; PHILLIPS, 2000; DIGELMANN; EVANS, 2004; EDWARDS; HARDING, 2004, MENKE et al., 2007; STOJADINOVIC et al., 2008).

\subsubsection{Etiologia e Epidemiologia}

O aumento da expectativa de vida e o rápido incremento da população idosa têm sido apontados como determinantes sociais da crescente prevalência de condições crônicas de saúde. Neste contexto, as úlceras cutâneas assumem importância, visto que podem estar relacionadas a doenças crônicodegenerativas associadas à idade, como doenças cardiovasculares, diabetes mellitus e artrite reumatóide. Projeções publicadas pela Organização Mundial de Saúde (OMS) estimam que a população idosa aumente cerca de sete a oito vezes até o ano 2025 (LIMA E COSTA et al., 2000).

A maioria das úlceras é causada por isquemia secundária a estase venosa, diabetes mellitus, e pressão. Úlceras que não cicatrizam, principalmente em pacientes idosos, podem tornar-se crônicas por anos ou mesmo levar estes pacientes a óbito (JAUL, 2009; MENKE et al., 2007).

Úlceras crônicas predominam nas extremidades dos membros inferiores e o diagnóstico etiológico, em geral, se relaciona à desordens do sistema vascular (FRADE et al., 2005; ROLDÁN-MARÍN et al., 2009). Cerca de 80\% das úlceras de perna estão relacionadas à insuficiência venosa crônica, 5\% a 10\% à doença 
arterial, e o restante a problemas neuropáticos (em geral, diabéticos) ou são de etiologia mista. Quanto à classificação, as úlceras podem ser venosas, hipertensivas, isquêmicas, anêmicas, do pé diabético e da tromboangeíte obliterante (PHILIPS; DOVERS, 1991).

A prevalência dos três principais tipos de úlceras é estimada entre três a seis milhões nos EUA, em pacientes com idade de 65 anos ou mais. Úlceras que não cicatrizam resultam em elevados custos para o sistema de saúde, com um custo total estimado em mais de três bilhões de dólares por ano (MENKE et al., 2007).

Nenhuma das estimativas financeiras leva em consideração o custo da perda de trabalho, diminuição da produtividade, ou custo para reabilitação. Além disso, o dano psicológico resultante aos pacientes e seus familiares é incalculável (MENKE et al., 2007). A qualidade de vida dos pacientes com úlceras crônicas pode ser extremamente baixa, e desta forma, implica em mais custos indiretos, dificultando a avaliação dos custos totais (CLARK et al., 2007).

No ano de 1992 registrou-se 35,2 milhões de casos de perda significante de pele nos EUA, os quais geraram grandes intervenções terapêuticas. Dentre estes casos, aproximadamente sete milhões tornaram-se crônicos. A causa mais comum de perda de pele foi lesão térmica, a qual contribui por aproximadamente um milhão de casos por ano nas emergências hospitalares nos EUA. Outras causas incluíram trauma e ulcerações crônicas secundárias a diabetes mellitus, pressão e estase venosa. De acordo com um levantamento realizado pelo Centro para prevenção e controle de doenças nos EUA, a estimativa da prevalência de diabetes na população americana é de 21 milhões de pessoas. Destas, em torno de dois milhões têm úlceras diabéticas crônicas e finalmente necessitam amputação, que em 1995 geraram custos médicos de 1,5 milhões de dólares (CLARK et al., 2007).

Nos EUA aproximadamente 600.000 pacientes têm úlceras venosas, com custo médio de dez mil dólares por paciente, outros 1,4 milhões têm úlceras por pressão. O custo total do tratamento para estes dois grupos tem sido estimado em oito milhões de dólares anualmente (CLARK et al., 2007).

Úlceras por pressão são um problema sério e frequente entre pacientes imobilizados e debilitados e contribuem significantemente para a morbidade e mesmo mortalidade de muitos pacientes. O custo relacionado ao cuidado do 
pacientes com úlceras de pressão é superior a 1,3 bilhões de dólares por ano (DIEGELMANN; EVANS, 2004).

Em 2003 uma pesquisa avaliou que o mercado americano de produtos para o cuidado de úlceras, incluindo curativos biológicos e sintéticos, é maior que 1,7 bilhões de dólares e estimou um aumento significativo conforme a população envelhece (CLARK et al., 2007).

Estudos realizados na União Européia têm estimado uma prevalência para úlceras de pé e perna de 1,48/1000 habitantes e com o avanço da idade, estes números aumentam (36/1000 habitantes com mais de 65 anos de idade). A prevalência anual de úlceras venosas de perna tem sido estimada em 1,69\% para indivíduos com 65 anos de idade ou mais (HOWELL-JONES et al., 2005).

Sobre a prevalência ou o número de pacientes com úlceras de perna no Brasil, são poucos os trabalhos publicados de característica nacional. Maffei (2002), em um estudo na região de Botucatu (SP) encontrou alta frequência de úlceras venosas nos pacientes varicosos, frequentemente desencadeadas por traumas. Esta alta frequência foi atribuída a ausência de tratamento e pouco cuidado com os varicosos na população de baixo nível socioeconômico. Na região de Belo Horizonte (MG) Cabral (2000), também encontrou alta prevalência $(2,6 \%)$ de úlcera venosas cicatrizadas ou abertas.

Frade et al. (2005), avaliaram 124 pacientes da cidade de Juiz de Fora (MG), com o objetivo de traçar um perfil clínico-epidemiológico dos portadores de úlceras de perna, avaliando os tipos mais frequentes de úlcera, doenças associadas e o perfil socioeconômico dos pacientes. Os autores verificaram que a média de idade foi 62,6 anos, predominando o sexo feminino $(65,3 \%)$ e renda menor que $\mathrm{R} \$ 540,00$ (86,8\%); associavam-se às úlceras: insuficiência venosa (74,2\%), hipertensão arterial sistêmica $(51,6 \%)$ e diabetes mellitus $(20,2 \%)$; clasificavam-se como venosas $(67,8 \%)$, hipertensivas $(20,1 \%)$, mistas e outras $(12,1 \%)$; acometiam preferencialmente o terço distal das pernas, $40 \%$ eram de tamanho médio $(2,0$ a $5,0 \mathrm{~cm})$ e $35,6 \%$ de tamanho grande $(>5,0 \mathrm{~cm})$, acompanhadas, principalmente, de hipercromia (92,5\%), lipodermatoesclerose $(68,8 \%)$ e varicosidades $(67,7 \%)$. Foi observado também que as úlceras apresentavam-se abertas em um período médio de 94,2 meses e 50\% delas apresentavam-se como quadros recidivantes.

Tais resultados evidenciam a importância da doença úlcera cutânea na vida dos pacientes, tendo em vista os aspectos socioeconômicos e psicológicos. 
Um paciente com uma úlcera que não cicatriza tem diminuição da qualidade de vida devido ao desconforto, mau odor, presença de secreção, além de dano à imagem corporal, a qual resulta em isolamento social (JAUL, 2009). Outras complicações de úlceras crônicas incluem limitações funcionais (como dificuldade de locomoção), dor crônica, infecções (celulite, formação de abscessos, osteomielite e mesmo sepse), potencial para malignidade (por exemplo, úlcera de Marjolin) e amputação (MENKE et al., 2007).

\subsection{Cicatrização}

O reparo tecidual é um processo biológico complexo, dinâmico e multifatorial que consiste em uma série de eventos sobrepostos, com a participação de diferentes tipos celulares, mediadores solúveis e componentes da matriz extracelular, resultando na restauração da função e continuidade anatômica da pele (DIEGELMANN; EVANS, 2004; GURTNER et al., 2008; SWAMY et al., 2004; STRONCEK; BELL; REICHERT, 2009; WALL et al., 2002). Figura 3.

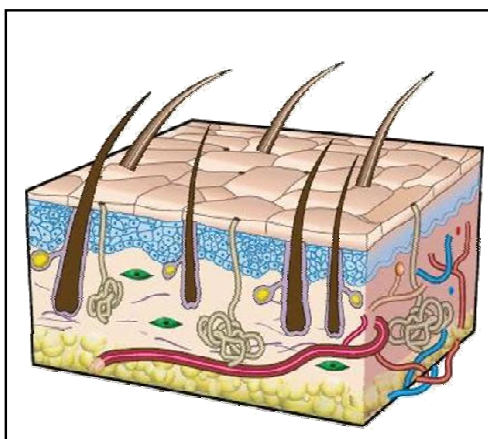

(a)

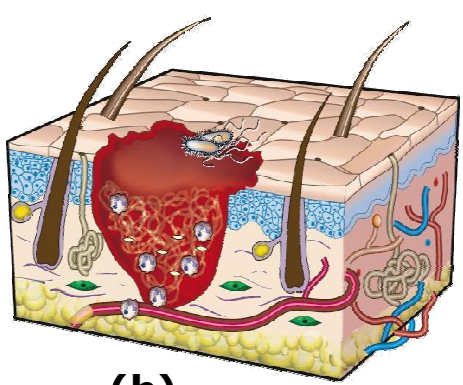

(b)

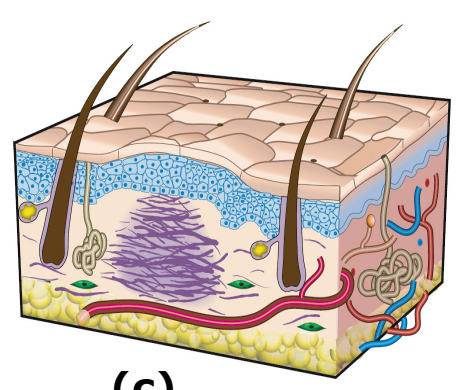

(c)

Figura 3 - Representação esquemática da pele íntegra (a), úlcera cutânea (b), característica do tecido cicatrizado (c) (GURTNER et al., 2008).

Existem quatro respostas básicas que podem ocorrer após uma lesão tecidual: reparo normal, reparo excessivo, reparo deficiente ou regeneração. No processo normal de reparo o equilíbrio é restabelecido entre a formação da cicatriz e seu remodelamento, esta é a resposta típica que ocorre na maioria dos 
casos. Na cicatrização excessiva existe muita deposição de tecido conjuntivo que resulta em estrutura alterada e perda de função. Quelóides e cicatrizes hipertróficas na pele são exemplos deste tipo de resposta. A cicatrização deficiente é o oposto e ocorre quando existe deposição insuficiente de tecido conjuntivo e o tecido é delicado ao ponto ser facilmente rompido; úlceras crônicas são exemplos de cicatrização deficiente. A regeneração ocorre quando existe perda de estrutura e função, mas o organismo tem a capacidade de repor a estrutura exatamente como era antes da lesão. Formas primitivas de vida como salamandras e caranguejos têm a capacidade de regeneração tecidual. Conforme o homem foi evoluindo, a capacidade de regeneração foi perdida e apenas uma quantidade limitada de tecidos como os tecidos hepático, ósseo, epiderme e em alguma extensão os nervos podem ser parcialmente regenerados após uma lesão. Além disso, o feto tem capacidade de reparo tecidual por um processo semelhante à regeneração (DIEGELMANN; EVANS, 2004).

Danos tissulares de qualquer natureza (física, química ou biológica) desencadeiam uma série de eventos celulares, bioquímicos e moleculares que resultam da ativação de células estromais, vasculares e circulatórias. Além disso, o microambiente do local lesado tem sua composição físico-química alterada (baixa tensão de oxigênio, diminuição de $\mathrm{pH}$, presença de espécies reativas de nitrogênio e oxigênio), sendo também uma outra forma de sinalização que ativa as células envolvidas no reparo tecidual (BALBINO; PEREIRA; CURI, 2005; GEER; SWARTZ; ANDREADIS, 2004).

Sinais químicos denominados fatores de crescimento ou citocinas direcionam diversas atividades que ocorrem durante a cicatrização. Originalmente estes sinais foram denominados fatores de crescimento, uma vez que o crescimento celular foi a principal função observada. Conforme mais informações foram adquiridas, tornou-se claro que estes fatores controlavam também a migração celular, produção de matriz, expressão e diferenciação enzimática. Portanto, o termo citocina pode ser uma melhor descrição para estes sinais químicos. Em geral, estes fatores são muito estáveis, entretanto, em uma úlcera crônica, onde existem níveis aumentados de enzimas proteolíticas, eles podem ser destruídos. Para que estes sinais modulem uma atividade celular, a célula alvo deve ter um receptor e uma vez que a ligação ao receptor ocorre, uma série de sinais intracelulares é ativada e finalmente resultará em uma resposta específica (DIEGELMANN; EVANS, 2004). 
Embora os eventos no processo cicatricial ocorram de maneira sobreposta, características distintas são observadas e desta forma o processo pode ser didaticamente divido em: hemostasia, inflamação, proliferação e remodelamento (DOUGHTY; SPARKS-DeFRIESE, 2012, JAUL, 2009; MENKE et al., 2008; STOJADINOVIC et al., 2008; STRONCEK; BELL; REICHERT, 2009).

Em resumo, a cascata normal da cicatrização inicia-se com um processo ordenado de hemostasia e deposição de fibrina, que leva à cascata inflamatória caracterizada pela presença de neutrófilos e macrófagos no tecido. Esta etapa é seguida pela atração e proliferação de fibroblastos e deposição de colágeno e finalmente remodelamento e maturação da cicatriz. Embora exista esta sequência ordenada de eventos responsável pela cicatrização normal, respostas patológicas podem ocorrer se qualquer parte do processo for alterada (DIEGELMANN; EVANS, 2004). Figura 4. 


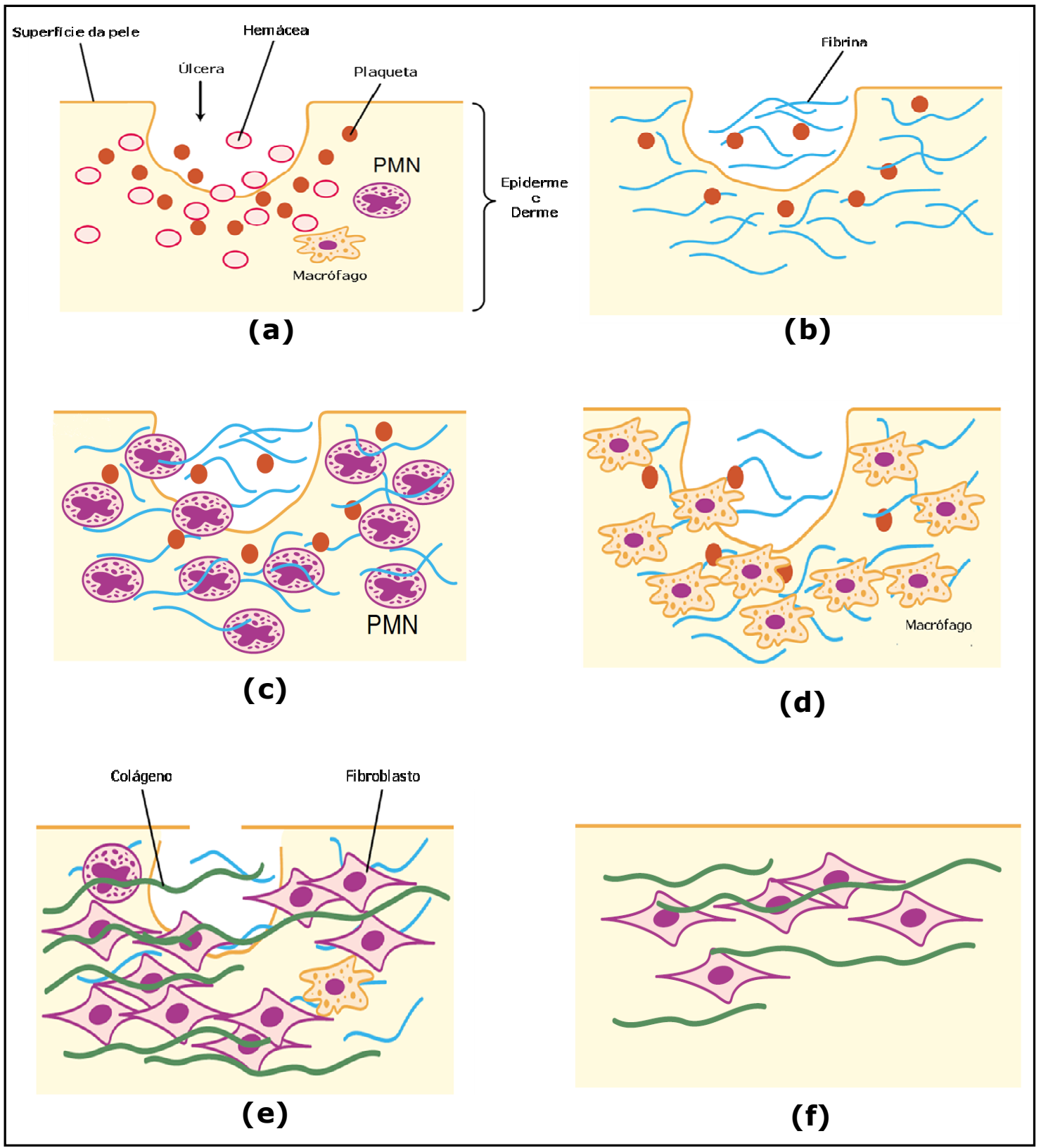

Figura 4 - Representação das fases do processo cicatricial: (a) Úlcera imediatamente após a lesão tecidual; (b) Hemostasia; (c) Início da fase inflamatória; (d) Fase inflamatória tardia; (e) Fase Proliferativa; (f) Fase de remodelamento. (Adaptado de BEANES et al., 2003) 


\subsubsection{Hemostasia}

O processo normal de cicatrização começa no momento que o tecido é lesado (Figura 4a). Após a lesão e rompimento de vasos sanguíneos, ocorre extravasamento de sangue, que preenche a área lesada com plasma e elementos celulares (plaquetas), e aumento da permeabilidade vascular com liberação de proteínas plasmáticas (fibrinogênio e fibronectina), aminas vasoativas e outros mediadores. Aminas vasoativas aumentam a permeabilidade vascular permitindo que células efetoras (plaquetas, neutrófilos, monócitos e linfócitos) e proteínas do plasma atinjam o local lesado. Uma vez que os componentes do sangue extravasam para o local da lesão, as plaquetas entram em contato com colágeno exposto e outros elementos da matriz extracelular (MEC), agregam-se e são ativadas, liberando fatores da coagulação e citocinas (DIEGELMANN; EVANS, 2004; MONACO; LAWRENCE, 2003).

As plaquetas se aderem às fibras de colágeno expostas no endotélio lesado por meio de receptores específicos (glicoproteínas - GPIb/IX/V). A ativação plaquetária resulta na liberação do seu conteúdo granular e estimula a ativação local dos fatores da coagulação plasmática. Estes fatores estimulam a polimerização da fibrina resultando no depósito de um coágulo de fibrina no local da lesão, também conhecido como "tampão plaquetário", levando à hemostasia (Figura 4b). A trombina desempenha função central na coagulação convertendo o fibrinogênio em fibrina e induzindo a degranulação plaquetária, com liberação de fator de crescimento derivado de plaqueta (PDGF), fator transformador de crescimento beta (TGF- $\beta$ ), fator de crescimento epitelial (EGF) e fator transformador de crescimento alfa (TGF-a) (BAUM; ARPEY, 2005; BEANES et al., 2003; FRADE, 2003; GURTNER et al., 2008; MANKAD; CODISPOTI, 2001; STOJADINOVIC et al., 2008; STRONCEK; BELL; REICHERT, 2009).

O coágulo age como uma barreira temporária prevenindo o sangramento excessivo e limitando a disseminação de patógenos para a corrente sanguínea. Inicialmente o coágulo é composto de plaquetas, fibrina e fibronectina, e serve como uma matriz provisória ou suporte para a migração celular (como neutrófilos, monócitos, fibroblastos e células endoteliais) e agregação plaquetária, que irão liberar fatores de crescimento no tecido circunjacente durante os eventos subsequentes do processo cicatricial (BAUM; ARPEY, 2005; 
BROUGHTON II; JANIS; ATTINGER, 2006b; CLARK et al., 2007; DIEGELMANN; EVANS, 2004; KARUKONDA et al., 2000; MONACO; LAWRENCE, 2003; STRONCEK; BELL; REICHERT, 2009). A remoção desta matriz provisória impede severamente o reparo da lesão (BEANES et al., 2003).

As plaquetas liberam não apenas os fatores da coagulação necessários para controlar o sangramento e perda de fluido e eletrólitos, mas também moléculas sinalizadoras (citocinas e fatores de crescimento), que iniciam a resposta cicatricial. Os dois fatores mais importantes são o fator de crescimento derivado de plaquetas (PDGF) e o fator transformador de crescimento-beta (TGFß). O PDGF inicia a quimiotaxia de neutrófilos, macrófagos, células de músculo liso e fibroblastos. Além disso, estimula a mitogênese de fibroblastos e células de músculo liso. TGF-ß adiciona outro sinal importante para o início da cascata da cicatrização por atrair macrófagos e os estimular a secretar citocinas adicionais incluindo fator de crescimento de fibroblastos (FGF), PDGF, TNF-a e IL-1 (DIEGELMANN; EVANS, 2004; STRONCEK; BELL; REICHERT, 2009). Células inflamatórias são quimiotaticamente atraídas ao reservatório de moléculas armazenadas no coágulo, o que inicia a inflamação, a próxima etapa na sequência do processo de cicatrização (STRONCEK; BELL; REICHERT, 2009).

\subsubsection{Fase Inflamatória}

A fase inflamatória é caracterizada pelos sinais típicos do processo inflamatório localizado, como dor, rubor, calor e edema, resultado da vasodilatação e da permeabilidade capilar aumentada (BAUM; ARPEY, 2005; MONACO; LAWRENCE, 2003). As principais células envolvidas nesta fase são os neutrófilos e os macrófagos e a principal função desta fase é preparar o local afetado para o crescimento do novo tecido (ABREU; MARQUES, 2005). Neutrófilos, macrófagos e fibroblastos elaboram óxido nítrico, radicais livres de oxigênio e proteases, que destroem bactérias, removem moléculas da MEC danificada e debris inflamatórios, e facilitam a migração celular através da MEC (STOJADINOVIC et al., 2008).

O processo de inflamação acontece para conter ou neutralizar o agente causador da lesão. O ambiente no qual inicia-se a inflamação é uma mistura de 
tecido lesado, componentes do coágulo (plaquetas, células sanguíneas vermelhas, fibrina), proteínas extravasadas do plasma, e material estranho introduzido no momento em que houve a lesão (STRONCEK; BELL; REICHERT, 2009).

Imediatamente após a formação do coágulo, um aviso celular é enviado e os neutrófilos são as primeiras células a responder (Figura 4c). Eles migram para a úlcera como resposta aos quimioatraentes liberados pelas plaquetas, assim como quimiocinas presentes nas membranas das células endoteliais; bactérias também liberam sinais químicos, atraindo neutrófilos que irão fagocitá-las. Conforme os mediadores inflamatórios se acumulam, e prostaglandinas são elaboradas, os vasos sanguíneos próximos ao local da lesão dilatam, estimulados por IL-1, TNF-a, TGF- $\beta$, e produtos bacterianos, para permitir o aumento do tráfico celular como, por exemplo, o tráfico de neutrófilos para a área lesada (BAUM; ARPEY, 2005; BROUGHTON II; JANIS; ATTINGER, 2006b; DIEGELMANN; EVANS, 2004). Componentes do sistema complemento também contribuem para a inflamação quando ativados por superfícies estranhas, como um implante ou parede celular bacteriana. Fragmentos do complemento, como C5a e C3a, são importantes ativadores inflamatórios induzindo o aumento da permeabilidade vascular e o recrutamento e a ativação de fagócitos (STRONCEK; BELL; REICHERT, 2009).

O receptor PSGL-1 dos leucócitos se liga a P-selectina expressa nas plaquetas e células endoteliais (marginação). A baixa afinidade da ligação leva os neutrófilos livres a rolarem (rolamento) e rapidamente se aderem às células endoteliais. $O$ receptor de neutrófilo ligado a quimiocinas ativa integrinas, que ligam os neutrófilos as células endoteliais (adesão). Subsequentemente, o neutrófilo extravasa através da parede vascular para o local da úlcera (diapedese), onde vai liberar enzimas proteolíticas para a digestão de restos celulares e contribuir para a morte de bactérias, por meio de fagocitose e produção de superóxido ou peróxido de hidrogênio (DOUGHTY; SPARKS-DeFRIESE， 2012; MONACO; LAWRENCE，2003; STRONCEK; BELL; REICHERT, 2009).

As principais funções dos neutrófilos são: remover material estranho, bactérias e células não-funcionais, e componentes danificados da MEC que podem estar presentes no local da úlcera (DIEGELMANN; EVANS, 2004). Se a descontaminação da úlcera é completa, os neutrófilos entram em apoptose dentro de 24 a 48 horas. À medida que o número de neutrófilos diminui, estes são repostos por monócitos recrutados da circulação sanguínea, ativados e diferenciados em macrófagos (Figura 4d), atraídos por citocinas como TGF- $\beta$ e 
PDGF (BEANES et al., 2003; CHETTIBI; FERGUSON, 1999; FRADE, 2003; HARDING; PATEL, 2002; STRONCEK; BELL; REICHERT, 2009). A presença de mastócitos no tecido lesado também contribui para a resposta inflamatória por liberarem histamina e serotonina para melhorar a permeabilidade capilar e promover a migração de macrófagos (STRONCEK, 2009).

Uma vez no tecido, várias enzimas (como por exemplo, colagenases) e citocinas, como IL-1, TNF-a, fator de crescimento do endotélio vascular (VEGF), PDGF e TGF- $\beta$ que atrairá fibroblastos e células de músculo liso para a úlcera, são secretadas pelos macrófagos. Interleucinas e TNF estimulam fibroblastos a produzir colágeno, VEGF estimula a angiogênese dentro do ambiente hipóxico do tecido (BROUGHTON II; JANIS; ATTINGER, 2006b). O TGF- $\beta$ secretado pelos macrófagos é considerado um dos principais atenuadores da inflamação e também estimula queratinócitos. Os macrófagos são altamente fagocíticos, sendo também responsáveis pela remoção de células não-funcionais, neutrófilos preenchidos com bactérias, MEC danificada, corpos estranhos, restos celulares e qualquer bactéria remanescente no leito da úlcera. Acredita-se que os macrófagos são mais importantes que os neutrófilos para a resolução satisfatória da inflamação. Em estudos onde os neutrófilos são depletados, o reparo não foi prejudicado, mas quando os macrófagos foram removidos, houve limpeza limitada do tecido necrótico no local da lesão, resultando em processo de cicatrização prolongado (BAUM; ARPEY, 2005; BEANES et al., 2003; DIEGELMANN; EVANS, 2004; GURTNER et al., 2008; STRONCEK, 2009).

A presença de macrófagos na úlcera é um marcador do final da fase inflamatória e início da fase proliferativa, portanto, macrófagos ativados são importantes para a transição de fases, e estes irão mediar angiogênese, fibroplasia e sintetizar óxido nítrico (BROUGHTON II; JANIS; ATTINGER, 2006b; DIEGELMANN; EVANS, 2004).

\subsubsection{Fase de Proliferação Tecidual}

A fase proliferativa da cicatrização sobrepõe a fase inicial de hemostasia e inflamação e envolve angiogênese, formação de matriz provisória e epitelização (STOJADINOVIC et al., 2008). Citocinas e fatores de crescimento liberados por 
células inflamatórias atraem fibroblastos dérmicos, miofibroblastos, células endoteliais e queratinócitos para a úlcera para iniciar a fase proliferativa do reparo tecidual (SCHMIDT et al., 2009). Esta fase é caracterizada pelo aumento da proliferação celular, brotamento capilar e síntese de matriz extracelular, com a deposição de colágeno, fibronectina e outros componentes protéicos para preencher o tecido danificado, restabelecendo a integridade da epiderme e derme (ABREU; MARQUES, 2005; BEANES et al., 2003; STADELMANN et al., 1998; STRONCEK; BELL; REICHERT, 2009).

A matriz é inicialmente composta de fibrinogênio e fibronectina. Logo em seguida, proteoglicanos e glicosaminoglicanos são sintetizadas por fibroblastos para constituir a substância de base da MEC. Tradicionalmente, existem duas classificações amplas para cicatrização. O tecido que tem pouco ou nenhum gap separando as bordas da úlcera (por exemplo, uma incisão cirúrgica), passará por uma cicatrização primária a partir das bordas da lesão. O tecido que for instável, com grande gap ou descontinuidade (por exemplo, uma úlcera de perna), passará por uma cicatrização secundária, onde um excesso de MEC é produzido para assegurar o preenchimento da área lesada. A MEC em uma cicatrização do tipo secundária, que subsequentemente se tornará vascularizada, é referida como tecido de granulação e em geral, a quantidade de tecido de granulação formada é proporcional ao nível de cicatriz final (STRONCEK; BELL; REICHERT, 2009)

Devido à alta atividade metabólica no local da úlcera, existe uma demanda aumentada para oxigênio e nutrientes. Fatores locais no microambiente da úlcera, tais como, baixo $\mathrm{pH}$, tensão de oxigênio reduzida e níveis aumentados de lactato, não apenas refletem perfusão tecidual inadequada secundária ao rompimento de capilares sanguíneos, como iniciam a liberação de fatores necessários para trazer um novo suprimento sanguíneo (BAUM; ARPEY, 2005; MONACO; LAWRENCE, 2003). Este processo é denominado angiogênese, neoformação capilar ou neovascularização e é estimulado principalmente por VEGF, além de outros fatores de crescimento como bFGF e TGF-ß. Células epidérmicas, fibroblastos, macrófagos e células endoteliais produzem estes fatores, que estimulam a migração e proliferação das células endoteliais dos vasos sanguíneos (ABREU; MARQUES, 2005; BROUGHTON II; JANIS; ATTINGER, 2006b). Macrófagos (via IL-1 e TNF-a) e fibroblastos (via fator de crescimento de queratinócitos (KGF-2) e TGF- $\beta$ ) mediam angiogênese por meio de VEGF, que é 
regulado por óxido nítrico e é um importante promotor da proliferação endotelial e angiogênese (GURTNER et al., 2008; STOJADINOVIC et al., 2008).

Conforme novos vasos entram na área da úlcera a tensão de oxigênio retorna ao nível normal (DIEGELMANN; EVANS, 2004). O tecido de granulação, que recebe esta denominação devido ao aspecto granular gerado pelos capilares neoformados no local da lesão, é composto por células inflamatórias (principalmente macrófagos), células endoteliais, neovasculatura, fibroblastos e miofibroblastos, em uma matriz frouxamente agregada, que precede 0 desenvolvimento do tecido cicatricial maduro (BAUM; ARPEY, 2005; BEANES et al., 2003; CLARK et al., 2007). A migração de capilares no leito da úlcera é crítica para a cicatrização apropriada (BROUGHTON II; JANIS; ATTINGER, 2006b; STADELMANN et al., 1998).

A formação do tecido de granulação e a deposição tecidual requerem nutrientes fornecidos pelos capilares e a falência deste processo resulta em uma úlcera cronicamente não-cicatrizada (BROUGHTON II; JANIS; ATTINGER, 2006b). Novos capilares fornecem as necessidades metabólicas para a migração e proliferação dos fibroblastos (fibroplasia), assim como para a produção de proteínas da MEC.

Os fibroblastos, células de origem mesenquimal, são células-chave na produção da MEC. Migram para o local da úlcera a partir do tecido circunjacente, tornam-se ativados, ligam-se a filamentos da matriz provisória de fibrina e começam a sintetizar colágeno e proliferar (Figura 4e). PDGF e EGF, liberados principalmente por plaquetas e macrófagos, são os principais sinais para a ativação dos fibroblastos. Em resposta ao PDGF, os fibroblastos começam a sintetizar a matriz provisória composta de glicosaminoglicanas e colágeno tipo III, contribuindo para a aquisição da resistência tensoravou da cicatriz (BEANES et al., 2003; BROUGHTON II; JANIS; ATTINGER, 2006b; DIEGELMANN; EVANS, 2004; MONACO; LAWRENCE, 2003; SCHMIDT et al., 2009). Os fibroblastos também produzem tenascina, fibronectina e proteoglicanas como o ácido hialurônico (HARDING; PATEL, 2002). Os fibroblastos são a única fonte de colágeno e fibronectina, principais proteínas que constituem o tecido conjuntivo na derme (CORSETTI et al., 2009).

O colágeno é a proteína mais abundante no reino animal, representa $30 \%$ do total de proteínas do corpo humano e 50\% do conteúdo protéico da cicatriz. Em tecidos normais, o colágeno proporciona força, integridade e 
estrutura. Quando os tecidos são rompidos após uma lesão, o colágeno é necessário para reparar o defeito e restaurar sua estrutura anatômica e função. Se excesso de colágeno for depositado no local da lesão, a estrutura anatômica normal da pele será perdida e ocorrerá fibrose. Por outro lado, se uma quantidade insuficiente de colágeno for depositada, a úlcera e consequentemente a cicatriz, serão frágeis e a úlcera pode tornar-se deiscente. A síntese adequada de colágeno é fundamental para a cicatrização de úlceras cutâneas (CORSETTI et al.,2009; DIEGELMANN; EVANS, 2004; MONACO; LAWRENCE, 2003).

Como outras proteínas, a síntese de colágeno depende da disponibilidade de aminoácidos (como glicina, L-prolina e L-lisina) encontrados na molécula final. Durante a síntese de colágeno existe um passo importante envolvendo a hidroxilação de resíduos de prolina e lisina. A hidroxilação gera pontes intra e intermoleculares que proporcionam ao colágeno sua flexibilidade, elasticidade e força peculiares. As moléculas de colágeno começam a formar sua tripla hélice característica e as cadeias recém-formadas são modificadas pelo processo de glicosilação. A molécula de pró-colágeno é então secretada nos espaços extracelulares onde será processada. A hidroxiprolina no colágeno é importante uma vez que esta proporciona a conformação helicoidal estável à molécula de colágeno. Quando a hidroxiprolina não está presente, por exemplo, em condições como falta de vitamina C (escorbuto), o colágeno tem estrutura alterada e pode sofrer desnaturação mais facilmente. Finalmente, o colágeno liberado no espaço extracelular passa pela clivagem dos peptídeos terminais N e C do pró-colágeno e a enzima lisil-oxidase proporciona a formação de ligações (crosslinks) mais estáveis. Conforme o colágeno torna-se maduro, mais ligações intra e intercelulares ocorrem nestas moléculas. Esta etapa importante de cross-linking proporciona, com o tempo, força e estabilidade ao colágeno (CORSETTI et al., 2009; DIEGELMANN; EVANS, 2004; DOUGHTY; SPARKS-DeFRIESE, 2012).

Gradualmente, parte dos fibroblastos, estimulados principalmente por TGF- $\beta$, alteram seu fenótipo migratório para pró-fibrótico diferenciando-se em miofibroblastos. Estas células são caracterizadas por possuírem um sistema actina e miosina e gerar forca contrátil, similar aquela encontrada em células de músculo liso. Desta forma, conduzirão à contração do leito aproximando as margens da úlcera, ou seja, reduzindo a área exposta da úlcera para que ocorra a formação da cicatriz. O leito aberto da úlcera finalmente fecha por contração e migração de células epiteliais a partir da borda da lesão. Contração reduzida 
pode levar ao retardamento da cicatrização, enquanto um excesso e/ou contração prolongada pode resultar em perda de função e cicatriz hipertrófica. Após o fechamento da úlcera, os miofibroblastos desaparecem por apoptose (BROUGHTON II; JANIS; ATTINGER, 2006b; FRADE, 2003; GURTNER et al., 2008; SCHMIDT et al., 2009; STOJADINOVIC et al., 2008).

Se a membrana basal permanece intacta, as células epiteliais migram para a superfície em um padrão normal e as camadas normais da epiderme são restauradas. Se a membrana basal foi destruída, as células epiteliais localizadas na borda da úlcera começam a proliferar e enviam projeções para restabelecer a função barreira protetora contra perda de fluidos e invasão bacteriana adicional. EGF, TGF- $\beta$, TGF-a, produzidos principalmente por plaquetas ativadas e macrófagos, estimulam a proliferação epitelial. Citocinas inflamatórias, como IL-1 e TNF-a estimulam fibroblastos a sintetizar e secretar KGF-1, KGF-2 e IL-6, os quais estimulam a migração, proliferação e diferenciação de queratinócitos (BAUM; ARPEY, 2005; BROUGHTON II; JANIS; ATTINGER, 2006b; MONACO; LAWRENCE, 2003; STOJADINOVIC et al., 2008).

A migração dos queratinócitos juntamente com a contração da ferida, resulta em reepitelização e fechamento da úlcera (HARDING; PATEL, 2002). O resultado final da fase proliferativa é vitalmente importante para a cicatrização, porque estabelece o suporte necessário para manter e reconstruir o tecido danificado (STRONCEK; BELL; REICHERT, 2009).

\subsubsection{Fase de Remodelamento Tecidual}

Uma vez que houve o fechamento da úlcera, inicia-se o remodelamento da cicatriz pelos próximos meses ou anos, com a redução progressiva da vascularização e do conteúdo celular no tecido cicatricial, aumento da força tensora e reorientação das fibras colágenas (Figura 4f) (ABREU; MARQUES, 2005; HARDING; PATEL, 2002). A matriz provisória, composta por colágeno tipo III, proteoglicanos e fibronectina é reposta por uma matriz mais espessa, resistente e organizada, composta por colágeno tipo I (DOUGHTY; SPARKSDeFRIESE, 2012; GURTNER et al., 2008). TGF- $\beta$ é o mediador predominante na maturação e remodelamento da úlcera, regulando a produção de 
metaloproteinases de matriz (MMPs) e de inibidores teciduais de metaloproteinases (TIMPs), e no remodelamento do colágeno (STOJADINOVIC et al., 2008). Clinicamente, a fase de remodelamento e maturação seja talvez a mais importante (BROUGHTON II; JANIS; ATTINGER, 2006b).

A fase de remodelamento tecidual tem início durante a homeostase entre síntese e degradação de colágeno e tem por objetivo restaurar a estrutura tecidual (ABREU; MARQUES, 2005; CORSETTI et al., 2009). Embora novo colágeno continue a ser depositado pelos fibroblastos, ocorre reabsorção da rede devido à atividade das colagenases, e as fibras colágenas rearranjam-se em uma estrutura mais organizada (STADELMANN et al., 1998; WITTE; BARBUL, 1997).

Se o paciente apresentar disfunções na deposição de matriz devido à dieta ou doença associada, a força/resistência da úlcera estará comprometida; se houver síntese excessiva de colágeno, o resultado da cicatrização poder ser uma cicatriz hipertrófica ou quelóide. A síntese aumentada de colágeno durante a cicatrização não deve-se apenas ao número aumentado de fibroblastos, mas também ao aumento da produção de colágeno por célula (BROUGHTON II; JANIS; ATTINGER, 2006b).

Nos tecidos que cicatrizaram por primeira intenção (cicatrização primária), ocorre pouco remodelamento devido à falta de MEC produzida durante o reparo. Como resultado, não existe cicatriz e o tecido reparado é virtualmente indistinguível do tecido normal. A cicatrização secundária, por outro lado, envolve alinhamento de fibras colágenas e contração para reduzir o tamanho da área lesada e restabelecer a força tecidual. O restabelecimento completo da força inicial é raramente obtido porque o tecido reparado permanece menos organizado que o tecido normal, o que resulta na formação da cicatriz. Se a úlcera é relativamente pequena e a reorganização da MEC é eficiente, ocorre pouca contração e pouca ou nenhuma cicatriz é observada. Entretanto, em grandes lesões onde existe extensivo reparo tecidual através da produção da MEC e remodelamento significante, uma cicatriz aparente será observada (STRONCEK; BELL; REICHERT, 2009).

As fibras de colágeno gradualmente se espessam e tornam-se orientadas paralelamente no leito da úlcera e se alinham às linhas de tensão da pele, resultando na aparência de tecido cicatricial estriado, oposto ao padrão de cesta entrelaçada observado no tecido dérmico normal. O novo tecido também caracteriza-se pela ausência de elastina, o que proporciona certa dureza à cicatriz quando comparada ao tecido normal (DOUGHTY; SPARKS-DeFRIESE, 2012; 
STRONCEK; BELL; REICHERT, 2009). Estas alterações também são acompanhadas por força tensora aumentada, indicativa de uma correlação positiva entre espessura e orientação das fibras colágenas e força tensora. O colágeno encontrado no tecido de granulação é bioquimicamente diferente do colágeno da pele intacta. O colágeno do tecido de granulação tem maior hidroxilação e glicosilação dos resíduos de lisina e este aumento da glicosilação está correlacionado com fibras mais finas (BROUGHTON II; JANIS; ATTINGER, 2006b).

A densidade capilar gradualmente diminui e a úlcera perde a coloração rosada tornando-se progressivamente pálida. Estruturas dérmicas, como folículos pilosos, glândulas sebáceas e sudoríparas, que foram perdidas durante a lesão não são regeneradas (ABREU; MARQUES, 2005; BAUM; ARPEY, 2005; STRONCEK; BELL; REICHERT, 2009).

O colágeno presente na cicatriz (mesmo após um ano de maturação) nunca será organizado como o colágeno encontrado na pele intacta. A força tensora da pele do local ulcerado também nunca retorna a 100\%. Em uma semana, a úlcera tem cerca de $3 \%$ de sua força tensora final, em três semanas cerca de $30 \%$, e em três meses (e após) aproximadamente $80 \%$, sendo o nível mais alto de força tensora que um tecido cicatrizado pode alcançar (DIEGELMANN; EVANS, 2004; GURTNER et al., 2008; STOJADINOVIC et al., 2008; STRONCEK; BELL; REICHERT, 2009).

\subsubsection{Complicações no processo cicatricial}

A complexidade da cicatrização torna as úlceras vulneráveis à interrupção em muitos estágios do processo de reparo. Fatores que alteram as respostas fisiológicas e as funções celulares podem potencialmente influenciar a cicatrização (BROUGHTON II; JANIS; ATTINGER, 2006b).

Dentre os fatores sistêmicos que podem alterar o processo cicatricial, encontram-se:

- Idade do paciente;

- Estado nutricional (deficiência protéica; deficiência de vitaminas A, C e Zinco);

- Doenças de base: diabetes, alterações cardiocirculatórias e de coagulação, anemia; 
- Quadros infecciosos sistêmicos;

- Medicamentos de uso sistêmico, como: Anticoagulantes, Corticosteróides.

Dentre os fatores locais, encontram-se:

- Dimensão e profundidade da úlcera;

- Suprimento sanguíneo inadequado (Isquemia)

- Presença de secreções, hematoma ou corpo estranho;

- Necrose tecidual;

- Hipóxia;

- Infecção local;

- Edema;

- Fatores mecânicos (excesso de mobilidade);

- Medicamentos de uso tópico e curativos. (BROUGHTON II; JANIS; ATTINGER, 2006; ENOCH; LEAPER, 2005; HALLORAN; SLAVIN, 2002; JAUL, 2009).

Além dos fatores sistêmicos e locais que podem comprometer a cicatrização, condições como redução dos fatores de crescimento teciduais, desequilíbrio entre enzimas proteolíticas e seus inibidores, e presença de células senescentes, também podem levar à não-cicatrização das úlceras (HARDING et al., 2002; WALL et al., 2002). Alterações associadas à isquemia e colonização bacteriana transformam a progressão normal da cicatrização em um ciclo autosustentável de inflamação e lesão. O recrutamento contínuo de neutrófilos resulta em níveis elevados e anormais de metaloproteinases de matriz (MENKE et al., 2008).

Metaloproteinases de matriz (MMPs) são endopeptidases que utilizam o zinco ou o cálcio nos seus sítios ativos; são secretadas como zimógenos inativos (pró-MMPs) e sua ativação é um pré-requisito para sua ação, que é regulada por uma série de inibidores enzimáticos, principalmente pela classe de enzimas denominadas inibidores teciduais de metaloproteinases (TIMPs) (INOMATA et al., 2003; LOBMANN et al, 2002).

A família de MMPs é constituída por mais de 25 enzimas, as quais incluem colagenases (MMP-1, 8, 13, 18), gelatinases (MMP-2, 9), estromelisinas (MMP-3, 10, 11), matrilisinas (MMP-7, 26), MMPs do tipo trans-membrana (MMP$14,15,16,17,24,25)$ e outras (CHENG et al., 2008).

As MMPs estão envolvidas no remodelamento de tecidos durante o desenvolvimento embriogênico, migração celular, cicatrização e desenvolvimento dentário. Entretanto, um desequilíbrio entre MMPs e TIMPs é característico de 
diversas condições patológicas como artrite reumatóide, osteoartrite, progressão de câncer e doenças cardiovasculares (KUPAI et al., 2010; SNOEK-VAN BEURDEN; VON DEN HOFF, 2005).

As MMPs têm a habilidade de regular a atividade de biomoléculas como os fatores de crescimento, citocinas e quimiocinas, assim como participam do processo de digestão de moléculas de adesão celular e proteínas da MEC e membrana basal. Estas atividades sugerem que estas enzimas atuem em outras fases do processo cicatricial, como na inflamação e reepitelização, e não apenas na fase de remodelagem tecidual, como acreditava-se inicialmente (GILL; PARKS, 2008). Desta forma, tornam-se importantes indicadores de prognóstico, assim como marcadores de repostas em estudos terapêuticos para a cicatrização.

A expressão de MMPs pode ser analisada por diferentes técnicas, porém a mais utilizada é a zimografia, a qual identifica a atividade das MMPs pela degradação do substrato e pelo peso molecular. Por exemplo, para a detecção de gelatinases (MMP-2, MMP-9), o substrato utilizado é a gelatina (KUPAI et al., 2010; LOMBARD et al., 2005; SNOEK-VAN BEURDEN; VON DEN HOFF, 2005).

Proporções anormais de MMPs (degradativas) TIMPs (protetoras) em úlceras crônicas levam a degradação de MEC, alterações no perfil de citocinas e concentração reduzida de fatores proliferativos (MENKE et al., 2008; MENKE et al., 2007).

O suprimento sanguíneo inadequado na úlcera, trauma e fatores sistêmicos aumentam os riscos de invasão bacteriana, dificultando a cicatrização. O desenvolvimento de infecção tem efeitos deletérios ao paciente, causando aumento de dor e desconforto, podendo levá-lo a óbito. O processo cicatricial é interrompido, levando ao aumento dos custos de tratamento e internação hospitalar (COOPER et al., 2002; DAVIES et al., 2007).

\subsubsection{Infecção}

A superfície cutânea, através dos mecanismos de defesa, ajuda a prevenir a invasão e o estabelecimento de bactérias potencialmente patogênicas à pele. A presença do estrato córneo fornece uma barreira física à invasão; o pH 
cutâneo altamente acídico e secreção de ácidos graxos e outros polipeptídios antibacterianos, fornecem uma barreira química. Desta forma, a flora bacteriana presente na pele intacta raramente ocasionará infecção. Entretanto, uma vez que a função barreira é rompida e a pele tem uma úlcera aberta, os tecidos subcutâneos tornam-se suscetíveis aos efeitos nocivos de bactérias e outros microrganismos (EDWARDS; HARDING, 2004; SCHMIDT et al., 2009; WARRINER; BURREL, 2005).

No leito da úlcera as bactérias não somente competem pelos nutrientes e oxigênio limitados, como também produzem endotoxinas e exotoxinas, que destroem ou alteram as atividades celulares normais. Endotoxinas são lipídeos e polissacarídeos localizados na parede celular bacteriana de microrganismos Gram-negativos. Quando liberadas, ativam sistemas regulatórios do organismo, como a inflamação. Exotoxinas são proteínas liberadas das bactérias que enzimaticamente modificam ou inativam células, causando sua morte ou alterando seu funcionamento normal (STOTTS, 2012).

Infecções em úlceras cutâneas são comuns em países em desenvolvimento principalmente devido às precárias condições de higiene da população. Dentre as bactérias frequentemente isoladas em cultura a partir de úlceras, encontram-se os gêneros Staphylococcus, Streptococcus, Enterococcus e bacilos Gram-negativos (DAVIES et al., 2007; STEPHENS et al., 2003), sendo os microrganismos Staphylococcus aureus, Streptococcus pyogenes, Corynebacterium spp., Escherichia coli, Pseudomonas aeruginosa, Streptococcus pneumoniae, Klebsiella pneumoniae, dentre outros, alguns dos mais importantes que levam à infecção de úlceras cutâneas. Entre os microrganismos mais comuns, estão o $S$. aureus e Streptococcus spp do grupo $\beta$-hemolítico, considerados microrganismos da flora transitória da pele (EDWARDS; HARDING, 2004; KUMAR et al., 2006; PATTANAYAK; SUNITA, 2008).

A interação entre úlcera e bactérias pode ser subdividida em quatro estados microbiológicos: contaminação, colonização, colonização crítica e infecção (EDWARDS; HARDING, 2004; HOWELL-JONES et al., 2005). Figura 5. 


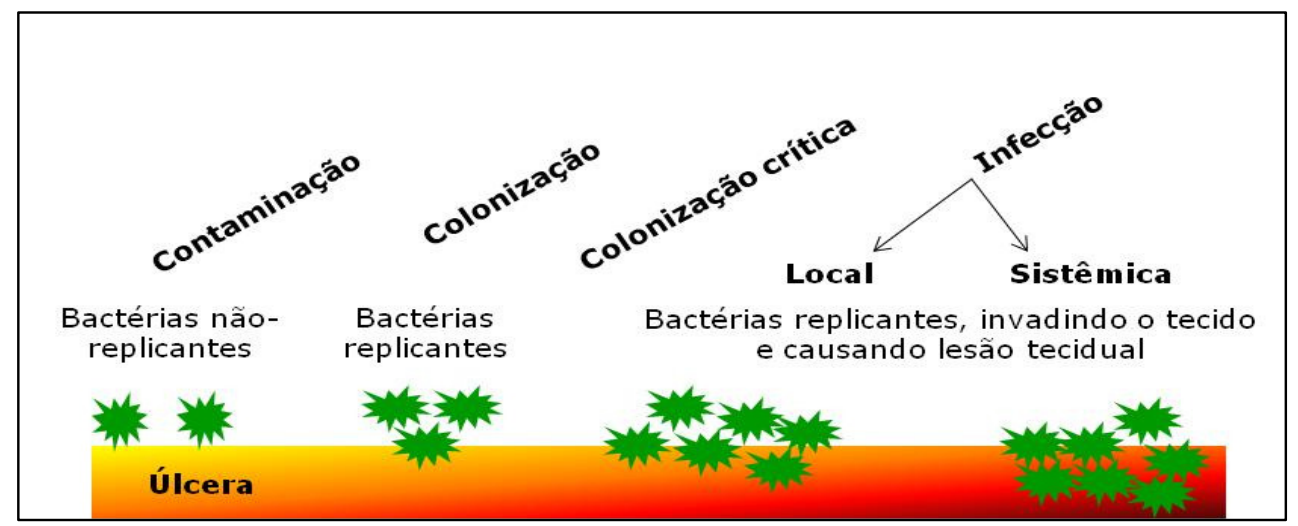

Figura 5 - Representação do espectro de infecção em uma úlcera cutânea. (Adaptado de LANDIS, 2008; WARRINER; BURREL, 2005).

Contaminação é a presença de microrganismos não-replicantes na superfície da úlcera. Contaminantes iniciais geralmente são microrganismos Gram-positivos (S. aureus, Corynebacterium spp, Streptococcus spp, Staphylococcus coagulase negativa), seguidos por microrganismos Gramnegativos (E. coli, Klebsiela spp, Proteus spp) (STOTTS, 2012).

Colonização é a presença de microrganismos replicantes e aderentes às úlceras, com ausência de dano tecidual. Todas as úlceras são contaminadas em algum grau. Mesmo aquelas definidas como úlceras cirúrgicas limpas, têm contaminação bacteriana. É bem aceito que úlceras crônicas são contaminadas e colonizadas, entretanto, existe um equilíbrio. Acredita-se que as úlceras passam de contaminadas à colonizadas quando as bactérias na superfície aumentam sua atividade metabólica e começam a replicar. Isso não torna-se patológico, a menos que o crescimento invasivo das bactérias ocorra dentro da úlcera, causando dano ao tecido e ao paciente (EDWARDS; HARDING, 2004; STOJADINOVIC et al., 2008; WARRINER; BURREL, 2005).

Os estados microbiológicos de contaminação e colonização não são patogênicos e não requerem tratamento com antibióticos locais ou sistêmicos. O uso inapropriado de antibióticos durante estas condições tem contribuído para a prevalência de resistência bacteriana (STOTTS, 2012).

Enquanto acredita-se que contaminação e colonização não retardam a cicatrização, o limite entre colonização e infecção é difícil de ser definido. Um estágio intermediário tem sido reconhecido na infecção contínua da úlcera, denominado colonização crítica, que representa a transição entre o estado de 
colonização e a infecção invasiva da úlcera. O termo colonização crítica tem sido utilizado para descrever o estágio em que as bactérias começam a afetar adversamente a cicatrização (HOWELL-JONES et al., 2005). É um termo relativamente novo e indica uma situação na qual a carga bacteriana excede a habilidade fisiológica do paciente quanto à remoção destes microrganismos, o que impede que a cicatrização prossiga normalmente (STOJADINOVIC et al., 2008).

Úlceras que estão criticamente colonizadas têm a cicatrização comprometida, visto que a carga bacteriana alta, produzindo proteases, leva a degradação da MEC. Consequentemente, a migração e proliferação de queratinócitos, assim como a deposição de colágeno na úlcera estão prejudicadas (STOJADINOVIC et al., 2008).

Indicadores de colonização crítica podem incluir: tecido de granulação friável, escuro ou vermelho-claro, ou ainda exuberante, aumento de exsudato, presença de odor e alteração ou aumento de dor. Quando suspeita-se de colonização crítica, antibióticos tópicos devem ser administrados e a situação do paciente deve ser reavaliada (STOTTS, 2012).

O termo infecção da úlcera pode ser definido como a presença de microrganismos replicando a um grau que resulta em dano significativo à cicatrização local, com subsequente dano ao paciente. Pode ser local e razoavelmente contida, mas também pode avançar, causando infecção sistêmica (EDWARDS; HARDING, 2004; WARRINER; BURREL, 2005).

A contagem bacteriana maior que $10^{5}$ unidades formadoras de colônias (UFCs) é considerada como padrão no diagnóstico de infecção da úlcera. Entretanto, a progressão do estágio de colonização para infecção depende não somente da contagem bacteriana ou das espécies presentes, mas também da resposta imune do paciente, virulência dos microrganismos e interações sinérgicas entre as diferentes espécies que podem estar presentes na úlcera (EDWARDS; HARDING, 2004; STOTTS, 2012).

O tecido de granulação em úlceras infectadas pode ter uma aparência não-saudável, mas como não existe invasão bacteriana dos tecidos, muitos dos sinais clínicos tradicionais de infecção estarão ausentes e o retardo da cicatrização pode ser o único sinal clínico (EDWARDS; HARDING, 2004).

Úlceras crônicas nem sempre apresentam os sinais e sintomas clássicos de infecção (dor, eritema, edema, calor e purulência), principalmente devido a 
fatores como idade avançada, diabetes, perfusão e oxigenação tecidual alterada, imunidade comprometida e uso de medicamentos antiinflamatórios. Uma lista expandida para a identificação clínica da infecção tem sido proposta. Esta inclui sinais específicos secundários às úlceras como: exsudato purulento associado à inflamação, cicatrização prolongada, rápido aumento do tamanho da úlcera, descoloração do tecido de granulação, tecido de granulação friável, forte odor, entre outros (FRANTZ, 2005; HOWELL-JONES et al., 2005; KUMAR et al., 2006).

Warriner e Burrel (2005), examinaram a validade de sinais clínicos e sintomas associados à infecção crônica localizada. Os resultados das observações clínicas foram comparados com os resultados de biópsias teciduais. Os achados clínicos que tiveram correlação positiva com as culturas, demonstrando a presença de infecção, foram: tecido de granulação friável, aumento no odor ou odor anormal, aumento de dor no local da úlcera, e fragilidade da úlcera. Sinais e sintomas tradicionais, entretanto, não precisam necessariamente estar presentes para uma úlcera crônica estar infectada. Neste estudo, sinais secundários e sintomas ocorreram mais frequentemente que sinais clássicos em úlceras crônicas infectadas, como demonstrado por biópsias das úlceras e cultura. Aumento de dor e fragilidade da úlcera são provavelmente os indicadores clínicos mais úteis.

Várias interações microrganismo-hospedeiro determinam se os organismos colonizantes progridem a invadir os tecidos e causar infecção da úlcera, particularmente a quantidade de bactéria por grama de tecido, a virulência e patogenicidade do organismo, e a habilidade do hospedeiro em desenvolver uma resposta imune efetiva (EDWARDS; HARDING, 2004). Quantidade aumentada de bactérias na superfície da úlcera e no tecido ulcerado aumenta os requerimentos metabólicos da úlcera e da resposta do hospedeiro à alta carga bacteriana, uma vez que estes microrganismos vão competir com células normais por oxigênio e nutrientes disponíveis (WARRINER; BURREL, 2005).

A infecção de úlceras cutâneas é diagnosticada clinicamente, associada a investigações microbiológicas, principalmente nos casos de úlceras clinicamente infectadas, para confirmar a presença de determinadas espécies bacterianas e identificar a sensibilidade a antibióticos; nos casos que não respondem ao tratamento convencional; e também para úlceras que falham em cicatrizar sem sinais clínicos de infecção, uma vez que podem estar localmente infectadas ou 
criticamente colonizadas (EDWARDS; HARDING, 2004). Quando os sinais e sintomas são mais sutis e a infecção é somente uma suspeita, culturas a partir da úlcera podem confirmar o diagnóstico. Um espécime válido deve incluir microrganismos do tecido viável da úlcera, e o caso deve então ser avaliado com base nos achados clínicos e na condição geral do paciente (WARRINER; BURREL, 2005).

Os espécimes clínicos para a investigação laboratorial podem ser obtidos a partir de biópsia tecidual, aspiração de exsudato com seringa, ou, com o uso de swab para a coleta de exsudato a partir do tecido abaixo da superfície da úlcera (EDWARDS; HARDING, 2004; FRANTZ, 2005).

O exame bacteriológico quantitativo é uma ferramenta útil na avaliação de infecção de úlceras cutâneas, determinando os tipos e números de microrganismos tanto no tecido profundo quanto na superfície das úlceras (STOJADINOVIC et al., 2008)

A avaliação da atividade antimicrobiana é um fator importante, uma vez que bactérias colonizantes no leito da úlcera podem levar à infecção ativa com subsequente interferência no processo cicatricial (SHAI; MAIBACH, 2005). Muitos estudos têm direcionado seu foco na utilização de compostos biologicamente ativos isolados de plantas medicinais para o tratamento de infecções em úlceras cutâneas, visto que muitos antibióticos apresentam efeitos adversos indesejáveis e para outros já existe resistência bacteriana (KUMAR et al., 2008; KUMAR et al., 2006; PATTANAYAK; SUNITA, 2008). Visto que a possibilidade de infecção em úlceras cutâneas é relativamente frequente, a busca por tratamentos que associem propriedades cicatrizantes e antimicrobianas em um mesmo produto assume grande importância.

\subsection{Tratamento}

Úlceras cutâneas não ocorrem como um evento isolado, portanto, uma avaliação completa do paciente é imperativa para estabelecer um plano de tratamento individualizado e prevenir degradação tecidual subsequente. A avaliação deve incluir a determinação da etiologia da úlcera (insuficiência arterial, drenagem venosa insuficiente, pressão mecânica, neuropatia, 
malignidade de base, infecção ou imunidade comprometida), assim como fatores locais e sistêmicos que contribuem para a falência da cicatrização (ROLSTAD; BRYANT; NIX, 2012; STOJADINOVIC et al., 2008). É importante quantificar o impacto da doença de base na cicatrização e tratá-la de maneira adequada para corrigir a anormalidade (HARDING; PATEL, 2002). A duração, localização, tamanho, odor, aparência da úlcera, assim como as características do tecido circunjacente devem ser documentados (MENKE et al., 2008).

Dentre os princípios para o cuidado de úlceras, são descritos: 1. Controlar ou eliminar os fatores causadores, com procedimentos como: redução de pressão e fricção no local ulcerado, uso de compressão para melhorar o retorno venoso e prevenção de trauma; 2. Fornecer suporte sistêmico para reduzir co-fatores existentes e potenciais: melhorar nutrição, proporcionar hidratação adequada, reduzir edema, promover fluxo sanguíneo; 3. Manter o ambiente local da úlcera em condições fisiológicas: prevenção e tratamento de infecção, limpeza da úlcera, remoção de tecido não-viável (desbridamento), manutenção de níveis apropriados de umidade, controle do odor, minimização de dor, proteção da pele na região peri-lesional (ROLSTAD; BRYANT; NIX, 2012).

O tratamento tópico de úlceras consiste em restaurar o ambiente fisiológico no leito da úlcera, visando umidade adequada, controle de temperatura, regulação de $\mathrm{pH}$ e controle da carga bacteriana. Estas condições uma vez ajustadas irão colaborar para o reparo e restauração da função tecidual. Nenhum tratamento tópico será eficaz se a condição patológica do paciente não for corrigida (ROLSTAD; BRYANT; NIX, 2012).

A terapêutica implica não apenas no conhecimento dos produtos (medicamentos, curativos) utilizados para promover a cicatrização, mas primeiramente no entendimento da fisiopatologia do processo cicatricial, pois a cada estágio do processo de reparo, a úlcera requer condições diferentes para progredir em direção à próxima etapa. Nem todos os tratamentos e curativos são indicados ou apropriados para serem usados continuamente até o fechamento da úlcera. A maioria das úlceras requer numerosas modificações conforme suas características se alteram ao longo do seguimento/tratamento. O tratamento deve ser reavaliado e readequado baseado nas características da úlcera e na resposta do paciente (ABREU; MARQUES, 2005; ROLSTAD; BRYANT; NIX, 2012).

Produtos destinados ao tratamento de úlceras cutâneas devem apresentar certas propriedades como: facilidade de aplicação e remoção, 
conforto ao paciente, manutenção de umidade adequada no leito da úlcera, entre outras (MANDELBAUM; DI SANTIS; MANDELBAUM, 2003).

Dentre as alternativas para o tratamento de úlceras cutâneas muitas plantas medicinais têm demonstrado possuir potencial terapêutico (PAIVA et al., 2002; SCHMIDT et al., 2009). Acredita-se que a utilização de óleos vegetais provenientes da flora brasileira possa oferecer vantagens tanto econômicas, para o país e para o paciente, quanto em termos de eficácia.

Princípios ativos isolados de plantas medicinais há muito tempo fazem parte da terapêutica, o que se deve, em parte, à grande variedade de espécies (250-500 mil) de plantas na flora mundial, muitas com importantes propriedades terapêuticas. Cerca de 120 metabólitos secundários de plantas são utilizados globalmente como drogas (KUMAR et al., 2006). Segundo dados da Organização Mundial de Saúde, estima-se que cerca de $80 \%$ da população mundial utilize plantas como primeiro recurso terapêutico, especialmente nos países subdesenvolvidos ou em desenvolvimento, devido principalmente à falta de acesso aos medicamentos sintéticos (KUMAR et al., 2006; SOUZA-JÚNIOR et al., 2002). A medicina popular é rica em exemplos de plantas utilizadas para diversas finalidades e é um aspecto relevante a ser considerado. Nos últimos anos, tem-se verificado aumento nos estudos que comprovam o que se conhece empiricamente (BANDEIRA et al., 1999; DATTNER, 2003; SILVA; CECHINEL FILHO, 2002). Entre as inúmeras espécies vegetais de interesse medicinal, estão as plantas do gênero Copaifera spp.

\section{5 Óleo de Copaíba}

O nome brasileiro comum das árvores do gênero Copaifera (família Leguminosae, sub-família Caesalpiniaceae) é aparentemente derivado da palavra em tupi cupa-yba que significa árvore de depósito, referindo-se a árvore com depósito de óleo-resina no seu interior (PLOWDEN, 2004). Figura 6. 


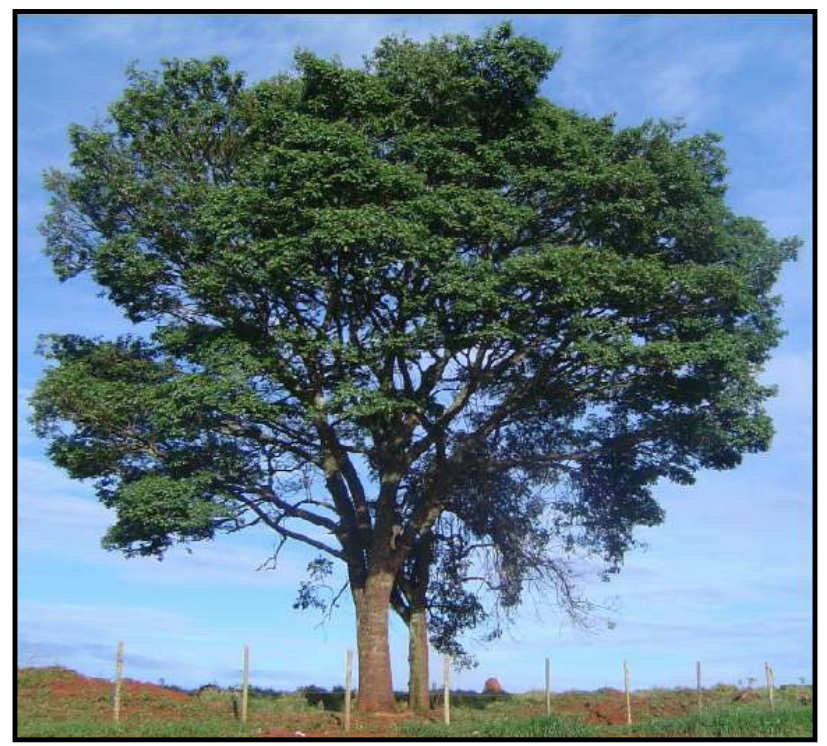

Figura 6 - Fotografia da árvore de copaíba (Copaibeira) (ÁRVORES DO BRASIL, 2010).

As copaibeiras são árvores comuns à América Latina e África Ocidental, sendo encontradas, no Brasil, nas regiões Sudeste, Centro-Oeste e Amazônica. Chegam a viver cerca de 400 anos, atingem altura entre 25 e 40 metros e diâmetro entre 0,4 e 4 metros (PIERI; MUSSI; MOREIRA, 2009).

O uso do óleo de copaíba, ou óleo-resina de copaíba, é difundido desde que os colonizadores europeus chegaram ao Brasil no século XVI; o conhecimento sobre as propriedades do óleo teve origem, provavelmente, da observação do comportamento de certos animais que, quando feridos, friccionavam-se nos troncos das copaibeiras para cicatrizarem suas lesões (VEIGA JÚNIOR; PINTO, 2002).

O primeiro relato do uso descreve a copaíba como copei em 1534 pelo papa Léo X (PLOWDEN, 2004). Por volta de 1560, o padre jesuíta José de Anchieta, em carta ao padre geral, comenta o poder cicatrizante do óleo de copaíba. Em meados do século XVI, em obra publicada sob o título "História da Província de Santa Cruz, que vulgarmente chamamos de Brasil", Pero de Magalhães Gândavo foi o primeiro a descrever a eficácia do óleo de copaíba como analgésico e cicatrizante, que resultou em um comentário mundial a respeito da copaíba, tornando o óleo, junto com o cravo, anil e tabaco, um dos quatro produtos mais exportados pelas províncias do Maranhão e Grão Pará (PIERI; MUSSI; MOREIRA, 2009).

Em 1625 um monge Português escrevendo sobre produtos naturais brasileiros descreveu uma droga denominada cupayba (PLOWDEN, 2004). A 
árvore foi primeiramente descrita em 1648, a farmacopéia Inglesa listou a droga em 1677 e Lineu descreveu o gênero Copaifera em 1762. No ano de 1821, o francês Desfontaines adicionou duas novas espécies ao gênero Copaifera: C. guianensis e $C$. langsdorffii (PIERI; MUSSI; MOREIRA, 2009). O óleo foi incluído na farmacopéia Americana de 1828 e em 1940 foi incorporado ao National Formulary (PLOWDEN, 2004).

Os primeiros relatos mencionaram a utilização medicinal do óleo-resina de Copaifera pelas populações indígenas, como Tupi, Puinaves, Kaw e Makunas, com a denominação tupi Kupaiwa, de onde originou-se o nome copaíva e depois copaíba (CASCON, 2004).

A copaíba é uma das plantas mais utilizadas pela população da Amazônia Brasileira, que em sua grande maioria não tem acesso a produtos farmacêuticos e aos serviços de saúde (CASCON; GILBERT, 2000).

No Brasil, a copaíba é conhecida como: pau-de-óleo ou pau-d'óleo, copaúba, copaúva, copiúva, copaí, copaíba angelim, copaíba mari-mari, copaíba roxa, óleo de copaíba ou bálsamo. Na América Latina: palo de bálsamo, aceite, cabima, cabimbo, currucai, maramo, palo de aceite e palo de aceitillo (Venezuela). Na língua inglesa: oleoresin, copaiba balsam ou copaiba oil, copaiba resin e Jesuit's balsam. Na língua francesa, a árvore é denominada copayer ou copahu, o óleo-resina: baume de copayer (ou copahu) e o óleo volátil: huile de copahu (CASCON, 2004).

O gênero Copaifera possui 72 espécies descritas, sendo 16 delas encontradas exclusivamente no Brasil. No continente Africano, na região do Congo, Camarões, Guiné e Angola, são descritas cerca de 19 espécies (PIERI; MUSSI; MOREIRA, 2009). As espécies se adaptam a diferentes regiões como pântanos, margens de rios e lagos, floresta tropical, subtropical e seca e savana (PLOWDEN, 2004).

As espécies relatadas como ocorrentes no Brasil são: Copaifera brasiliensis Dwyer, C. langsdorffii Desf., C. cearensis Huber, C. contertifolia Benth., C. coriacea Mart., C. duckei Desf., C. elliptica Dwyer, C. luetzelburgii Harms, C. malmei Harms, C. marginata Benth., C. marjorina Dwyer, C. martii Hayne, C. multijuga Hayne, C. oblongifolia Mart., C. officinalis L., C. paupera Dwyer, C. piresii Ducke, C. pubiflora Benth., C. reticulata Ducke, C. rondonii Hoehne, C. trapezifolia Hayne; C. guianensis Desf. (CASCON, 2004; CASCON; GILBERT, 2000; VEIGA JÚNIOR; PINTO, 2002).

Entre as espécies mais abundantes no Brasil e América do Sul, estão: $C$. officinalis L. (Norte do Amazonas, Roraima, Colômbia e Venezuela), C. guianensis 
Desf. (Guianas), C. langsdorffii Desf. (Brasil, Argentina, Paraguai) C. reticulata Ducke, C. multijuga H. (Amazônia), C. contertiflora Bth., C. coriacea Mart. (Bahia), e C. cearensis H. (Ceará) (PIERI; MUSSI; MOREIRA, 2009; VEIGA JÚNIOR; PINTO, 2002).

Em determinada região pode haver o predomínio de uma espécie, mas normalmente várias coexistem, fazendo com que os óleos de copaíba comercializados nos mercados regionais sejam misturas das espécies ocorrentes na área da coleta (CASCON, 2004).

A obtenção do óleo-resina é realizada através da perfuração, por meio de um trado ou perfurador, da parte superior do tronco da copaibeira até o lenho, onde se encontram os reservatórios do óleo-resina; posteriormente fecha-se este orifício com um batoque (rolha) para efetuar outro orifício na parte inferior do tronco. O óleo começa a escorrer lentamente pelo conduto, logo que se abre o orifício superior. Na primeira extração, a quantidade de óleo-resina extraído pode variar. A média de retirada de óleo, por vez para cada árvore, varia de 0,3 a 3 litros, dependendo da espécie e condições às quais está submetida, e algumas árvores podem chegar a fornecer até 30 litros em uma única retirada. Após a coleta, vedam-se os dois orifícios com argila ou cera vegetal (BANDEIRA et al., 1999; CASCON, 2004; PIERI; MUSSI; MOREIRA, 2009).

O óleo-resina de copaíba consiste de grandes quantidades de óleos voláteis (principalmente sesquiterpenos), resinas não-voláteis e pequenas quantidades de ácidos. A combinação de sesquiterpenos e diterpenos pode ser responsável pela resistência da planta a ataques por insetos e bactérias (PLOWDEN, 2004). Estudos fitoquímicos do óleo-resina da Copaifera langsdorffii demonstraram que a presença destes compostos seja responsável pelas atividades biológicas (PAIVA et al., 2002; SANTOS et al., 2008a, b). Apesar de poderem estar presentes em quantidades e tipos diferentes, essas classes de substâncias estão sempre presentes nos óleos de copaíba. Setenta e dois sesquiterpenos e vinte e sete diterpenos foram identificados. Os principais sesquiterpenos encontrados no óleo-resina da copaíba são o beta-cariofileno e o beta-bisaboleno, e entre os diterpenos estão os ácidos copálico, hardwickiico e covalênico (MONTES et al., 2009; PIERI; MUSSI; MOREIRA, 2009; RAMOS, 2006; RIGAMONTTE-AZEVEDO et al., 2004). A frequência dos principais terpenos encontra-se representada na Tabela 1. Em um estudo conduzido por Veiga Júnior e cols. (1997), em análise por cromatografia gasosa de alta resolução 
acoplada à espectrometria de massas de diferentes óleos de copaíba, o ácido copálico foi o único composto a ser detectado em todos os óleos estudados, indicando que este diterpeno possa ser utilizado como biomarcador para o gênero Copaifera.

Tabela 1 - Frequência relativa dos terpenóides detectados em amostras de óleo de copaíba. (Adaptada de RIGAMONTTE-AZEVEDO et al., 2004).

\section{Terpenos Frequência (\%)}

\begin{tabular}{cc}
\hline Sesquiterpenos & \\
$\beta$-cariofileno & 100 \\
$\beta$-humuleno & 62,50 \\
$\beta$-bisaboleno & 62,50 \\
$\beta$-elemeno & 50,0 \\
a-bergamoteno & 37,50 \\
a-copaeno & 37,50 \\
a-cadineno & 37,50 \\
Diterpenos & \\
Ácido copálico & 75,0 \\
Ácido hardwickiico & 75,0 \\
Ácido covalênico & 75,0 \\
Ácido caurenóico & 62,50 \\
\hline
\end{tabular}

A composição química, cor, odor e viscosidade do óleo-resina variam entre as espécies. Por exemplo, o óleo-resina proveniente da $C$. reticulata é viscoso, amarelo escuro, com odor desagradável, e mais de $80 \%$ de sesquiterpenos totais; o óleo-resina proveniente da $C$. langsdorffii tem consistência de óleo de oliva (PLOWDEN, 2004).

O crescimento da indústria de produtos naturais nos últimos anos levou à comercialização extensiva do óleo de copaíba pelos laboratórios farmacêuticos. Da região Amazônica, que é o principal fornecedor, o óleo é enviado para outras regiões do país e também exportado para a Europa e América do Norte, podendo ser encontrado encapsulado ou envasado, na forma líquida, em frascos (VEIGA JÚNIOR; PINTO, 2002). Foi aprovado em 1972 pelo Food and Drug Administration (FDA) para uso em alimentos, uma vez que não foram observadas 
reações de irritação e sensibilização nos voluntários avaliados (MENDONÇA et al., 2005; OPDYKE, 1973; PLOWDEN, 2004).

O Brasil é o maior produtor e exportador do óleo de copaíba, seguido por países como Venezuela, Colômbia, Suriname e Guiana, porém com menor venda de óleo-resina. Medir a produção é difícil, mas a exportação brasileira teve um pico de 225 toneladas em 1917 e tem variado entre 50 e 120 toneladas por ano desde 1940. O estado do Amazonas substituiu o estado do Pará como maior exportador de copaíba, e os estados de Rondônia e Amapá também constam como exportadores. Os Estados Unidos têm importado cerca de 8 a 100 toneladas por ano, e França e Alemanha são os outros dois maiores importadores. Dada à tamanha popularidade da copaíba, é compreensível que a mesma ainda seja explorada como fonte econômica para muitas comunidades da região norte do Brasil, especialmente da região Amazônica (PLOWDEN, 2004).

Na medicina popular, principalmente na região Amazônica, o óleo-resina de copaíba vem sendo utilizado, topicamente, como antiinflamatório, cicatrizante, no tratamento de gonorréia crônica e de afecções cutâneas como eczema, herpes, leishmaniose e psoríase (CARVALHO et al., 2005; PLOWDEN, 2004; VEIGA JúNIOR; PINTO, 2002). O uso interno inclui o tratamento de problemas envolvendo membranas mucosas, como asma, bronquite, condições geniturinárias (incluindo cistite, leucorréia, sífilis e incontinência urinária). Também tem sido usado como anti-séptico, antibacteriano (em aplicações odontológicas e outras), anti-neoplásico, expectorante entre outros (PLOWDEN, 2004).

Dentre as várias propriedades medicinais, as atividades: antiinflamatória, anti-tumoral (contra sarcoma de Walker e melanoma), anti-ulcerogênica, antioxidante, anti-reumática, anti-séptica, acaricida (carrapato do boi), larvicida (Aedes aegypt), gastroprotetora, anti-edematogênica, anti-lipoperoxidativa, cicatrizante, repelente de insetos e antimicrobiana têm sido relatadas na literatura científica (ARAÚJO-JÚNIOR et al., 2005; BRANDÃO et al., 2008; CASCON; GILBERT, 2000; FERNANDES; FREITAS, 2007; GOMES et al., 2007; LIMA SILVA et al., 2009; LIMA SILVA et al., 2003; PAIVA et al., 1998; SILVA et al., 2007; PIERI; MUSSI; MOREIRA, 2009; SALVADOR; MASSON; FRADE, 2008; SOUZA-JÚNIOR et al., 2002; STUPP et al., 2007; VEIGA JÚNIOR; PINTO, 2002; VEIGA JÚNIOR et al., 2006).

Dentre as propriedades medicinais estudadas, a mais citada é a antiinflamatória. Estudos indicam que o óleo de copaíba possui atividade 
antiinflamatória e analgésica (VEIGA JÚNIOR; PINTO, 2002). Carvalho et al. (2005), também sugerem que o óleo-resina possui atividade antiinflamatória e analgésica, após avaliação da aplicação tópica em ratos, no modelo de edema de pata induzido por carragenina. Gomes et al (2007), avaliaram a atividade antinociceptiva do óleos-resina de $C$. multijuga $\mathrm{H}$. e C. reticulata D. administradas por via oral em camundongos e demonstraram que os óleos-resina apresentaram atividade, provavelmente por ligação a receptores opióides e não observou-se toxicidade, reforçando a importância do óleo como fitoterápico.

$\mathrm{Na}$ área odontológica, a utilização do óleo de copaíba também vem sendo pesquisada, principalmente quanto às atividades bactericida e bacteriostática (BANDEIRA et al., 1999; VALDEVITE, 2007).

Além das propriedades terapêuticas, a copaíba possui crescente aplicação na indústria química e cosmética (SOUZA-JÚNIOR et al., 2002). São descritas aplicações do óleo-resina em tintas, vernizes, lacas; e na indústria cosmética, como fragrância ou fixador de odor em sabonetes, xampus, loções, perfumes e detergentes (CASCON, 2004). O óleo-resina viscoso é utilizado como fixador de perfume, uma vez que seu conteúdo oleoso volátil é mais baixo e permite menos evaporação (PLOWDEN, 2004).

Como pode ser verificado na literatura científica, a eficácia da copaíba vem sendo confirmada. Além disso, o fato do óleo possuir aceitação popular reconhecida, especialmente na região norte brasileira, que em sua grande maioria não tem acesso a produtos farmacêuticos e aos serviços de saúde, justifica a tentativa de viabilizar seu emprego como fitoterápico, de uma forma segura, eficaz e com qualidade. A utilização de recursos naturais que contribuam para a melhoria da saúde da população brasileira, também pode servir como base para o desenvolvimento sustentável e a preservação do meio ambiente (CASCON; GILBERT, 2000).

No entanto, nenhum estudo sobre estas atividades foi encontrado relatando a incorporação do óleo-resina de copaíba em creme para uso tópico no tratamento de úlceras cutâneas, daí a importância de se verificar a atividade cicatrizante nestas condições, além dos estudos de citotoxicidade. Outro fator importante é a avaliação da atividade antimicrobiana, uma vez que bactérias colonizantes no leito da úlcera podem levar à infecção ativa com subsequente interferência no processo cicatricial. 
"Tudo o que um sonho precisa para ser realizado é alguém que acredite que ele possa ser realizado". Roberto Shinyashiki 


\section{JUSTIFICATIVA}

Diante dos grandes avanços na compreensão dos fenômenos envolvidos no processo de reparo tecidual, a incidência de úlceras cutâneas crônicas ainda se mantém alta, repercutindo em custos elevados e consequências diretas na qualidade de vida dos pacientes, tornando-se relevante a busca do conhecimento de novas possibilidades terapêuticas e respectivas eficácia e segurança quanto ao estímulo à cicatrização.

Muitas plantas medicinais têm demonstrado potencial terapêutico e dentre elas, destacam-se as do gênero Copaifera spp, cujo óleo-resina tem sido utilizado popularmente principalmente como antiinflamatório e cicatrizante.

No entanto, estudos de atividade do óleo-resina na cicatrização de úlceras cutâneas, seu real mecanismo de ação, sua toxicidade e atividade antimicrobiana frente a microrganismos importantes na infecção de úlceras, assim como atividade antimicrobiana in vivo, permanecem escassos e muitas vezes inconclusivos.

Desta forma, buscou-se avaliar os possíveis mecanismos de ação do óleo-resina de copaíba na cicatrização de úlceras cutâneas com e sem infecção, antecedendo sua aplicação e concentrações seguras para o uso na prática clínica, possibilitando assim, a melhoria da assistência e da qualidade de vida dos pacientes com úlceras cutâneas crônicas. 


\section{Objetivos}

"Quase tudo é possível quando se tem dedicação e habilidade. Grandes trabalhos são realizados não pela força, mas pela perseverança".

Autor desconhecido 


\section{OBJETIVOS}

\subsection{Gerais}

> Avaliar a citotoxicidade do óleo-resina de copaíba in vitro; sua atividade cicatrizante em dois modelos animais distintos: coelho e rato; seus efeitos no modelo ex vivo de cicatrização; sua atividade antimicrobiana in vitro e em úlceras cutâneas infectadas, além de seu potencial cicatrizante em úlceras cutâneas infectadas em ratos.

\subsection{Específicos}

Avaliar a citotoxicidade do óleo-resina de copaíba em culturas de fibroblastos NIH-3T3 (Estudo 1);

Avaliar o potencial cicatrizante do óleo-resina de copaíba em úlceras cutâneas no modelo da orelha de coelho (úlcera excisional não-contrátil) (Estudo 2);

- Avaliar o potencial cicatrizante do óleo-resina de copaíba em úlceras cutâneas utilizando ratos (úlcera excisional contrátil) (Estudo 3);

Avaliar o efeito do óleo-resina de copaíba no modelo ex vivo de cicatrização da pele humana (culturas organotípicas de explantes de pele humana) (Estudo 4);

Avaliar a atividade antimicrobiana in vitro do óleo-resina de copaíba em bactérias associadas a úlceras infectadas. Bactérias Gram-positivas (Staphylococcus aureus, Streptococcus pyogenes, Enterococcus faecalis) e Gram-negativas (Pseudomonas aeruginosa e Escherichia coli) (Estudo 5); 
Avaliar a atividade antimicrobiana in vivo do óleo-resina de copaíba em úlceras cutâneas infectadas em ratos (Estudo 6);

Avaliar o potencial cicatrizante do óleo-resina de copaíba em úlceras cutâneas infectadas em ratos (Estudo 7). 


\section{Material e Métodos}

"Reparta o seu conhecimento. É uma forma de alcançar a imortalidade". Dalai Lama 


\section{MATERIAL E MÉTODOS}

Os protocolos envolvendo o uso de animais de experimentação (coelhos) foram realizados de acordo com os Princípios Éticos na Experimentação Animal adotado pelo Colégio Brasileiro de Experimentação Animal (COBEA). O projeto foi aprovado pela Comissão de Ética em Experimentação Animal (CETEA), da Faculdade de Medicina de Ribeirão Preto, Universidade de São Paulo (FMRP-USP), sob o número de processo 048/2007 (ANEXO A).

Os procedimentos envolvendo o uso de fragmentos de pele humana para cultura foram aprovados pelo Comitê de Ética do Hospital das Clínicas da Faculdade de Medicina de Ribeirão Preto, Universidade de São Paulo, sob o número de processo HCRP 5606/2008 (ANEXO B).

Os protocolos envolvendo o uso de animais de experimentação (ratos), realizados durante o Programa de Doutorado no País com Estágio no Exterior (PDEE), foram aprovados pelo Institutional Animal Care and Use Committee (protocolo 09-10\#20) (ANEXO C) e também pelo Department of University Safety \& Assurances, Biological Safety Program - Institutional Biosafety Committee (protocolo \#10-Enwemeka-01) (ANEXO D) da University of Wisconsin - Milwaukee (UWM), Estados Unidos da América (EUA).

O óleo-resina utilizado para os estudos foi obtido da espécie Copaifera langsdorffii, o qual foi colhido na região de Tarauacá, AC, localização geográfica: latitude $9^{\circ} 41^{\prime} 0^{\prime \prime}$ Sul, longitude $72^{\circ} 5^{\prime} 0^{\prime \prime}$ Oeste, entre os anos de 1999 e 2000. O óleo foi obtido da Central de Cooperativas de Rio Branco pelo professor Dr. Osvaldo de Freitas, da Faculdade de Ciências Farmacêuticas de Ribeirão Preto (USP), que gentilmente nos cedeu o produto. A adição do óleo-resina em creme, assim como o preparo do creme base foram realizados pela farmácia de manipulação Doce Erva (Ribeirão Preto/SP). 


\subsection{Animais}

\subsubsection{Coelhos}

Foram utilizados coelhos brancos, da raça Neozelandesa, machos, com peso médio entre 1,5 e 3,0 kg, fornecidos pelo Biotério Central da Faculdade de Medicina de Ribeirão Preto da Universidade de São Paulo. Após o procedimento cirúrgico, os animais foram mantidos em gaiolas individuais sob as condições padrão do Biotério do Departamento de Clínica Médica da FMRP-USP: temperatura de $25 \pm 5^{\circ} \mathrm{C}$, ciclos de luminosidade de 12 horas, ração e água ad libitum. Os animais foram recebidos três dias antes do início de cada período experimental e mantidos sob as condições padrão, para aclimatização.

\subsubsection{Ratos}

Foram utilizados ratos da raça Wistar, machos, com peso médio entre 300 e 340 g adquiridos da empresa Charles River Laboratories (Wilmington, Massachusetts - EUA). Os animais foram mantidos individualmente em caixas de polipropileno estéreis sob as condições padrão do biotério (Animal Resource Center. University of Wisconsin - Milwaukee, EUA): temperatura de $25 \pm 5^{\circ} \mathrm{C}$, umidade de $50 \%$, ciclos de luminosidade de 12 horas e receberam dieta padrão para roedores e água ad libitum. Os animais foram recebidos sete dias antes do início de cada período experimental e mantidos sob as condições padrão, para aclimatização. 


\subsection{Metodologia}

\subsubsection{ESTUDO 1: Avaliação da citotoxicidade do óleo-resina de copaíba em cultura de fibroblastos NIH-3T3}

\subsubsection{Cultura celular}

Sob condições estéreis, fibroblastos NIH-3T3 foram descongelados em banho-maria à temperatura de $37^{\circ} \mathrm{C}$ e transferidos para um tubo cônico de 15 $\mathrm{mL}$. Adicionou-se $10 \mathrm{~mL}$ de meio de cultura RPMI e centrifugou-se a $1200 \mathrm{rpm}$ durante 10 minutos. O sobrenadante foi descartado e o pellet foi ressuspenso em $10 \mathrm{~mL}$ de meio de cultura Iscove suplementado com $10 \%$ de soro bovino fetal e $1 \%$ de solução de antibiótico e antimicótico (penicilina $100 \mathrm{U} / \mathrm{mL}$, estreptomicina $100 \mathrm{mg} / \mathrm{mL}$ ). Em seguida as células foram plaqueadas em garrafas de cultura utilizando o mesmo meio (Iscove). As garrafas foram incubadas a $37^{\circ} \mathrm{C}$ em estufa com $5 \%$ de tensão de $\mathrm{CO}_{2}$. Após três dias as células foram expandidas: lavou-se as garrafas com tampão PBS por duas vezes, incubou-se com solução de Tripsina a $0,2 \%$ a $37^{\circ} \mathrm{C}$ durante 10 minutos. 0 volume da garrafa de cultura foi transferido para um tubo cônico e centrifugado a $1000 \mathrm{rpm}$ durante 10 minutos, desprezou-se o sobrenadante, ressuspendeu-se o pellet com o meio de cultura Iscove e plaqueou-se novamente, o que representou a segunda passagem. Os mesmos procedimentos de cultura e tripsinização foram repetidos até a quinta passagem. Após a tripsinização, as células foram contadas em Câmara de Neubauer para utilização nos testes de viabilidade e proliferação celular.

\subsubsection{Avaliação da Viabilidade Celular}

As células NIH-3T3 foram plaqueadas em microplacas de 96 poços de fundo plano, na densidade de $10^{5}$ células (volume de $200 \mu \mathrm{L}$ ), por poço, em triplicata. As 
placas foram incubadas durante 24 horas a $37^{\circ} \mathrm{C}$ em estufa com $5 \%$ de tensão de $\mathrm{CO}_{2}$ para a obtenção de crescimento confluente. Após este período, observou-se aderência das células e então o todo o volume do meio de cultura foi aspirado e adicionou-se $200 \mu \mathrm{L}$ das soluções teste contendo óleo-resina de copaíba de forma que as concentrações finais fossem: 1,0; 10; 50;100; 500 e $1000 \mu \mathrm{g} / \mathrm{mL}$, meio de cultura Iscove (controle) e meio de cultura Iscove acrescido de DMSO (controle da viabilidade, uma vez que as soluções de óleo-resina continham DMSO), separadamente, em triplicata. As placas foram incubadas a $37^{\circ} \mathrm{C}$ em estufa com $5 \%$ de tensão de $\mathrm{CO}_{2}$ durante 24 horas. Após este período, o conteúdo dos poços foi removido e os mesmos foram lavados duas vezes com tampão PBS. Solução estoque de 3-[4,5-dimetiltiazol-2-il]-2,5-difenil-brometo de tetrazólio (MTT) (5 $\mathrm{mg} / \mathrm{mL}$ em PBS) foi adicionada $(20 \mu \mathrm{L})$ associada a meio de cultura DMEM (sem vermelho de fenol) (180 $\mu \mathrm{L})$ e as placas foram incubadas sob as mesmas condições anteriores durante 3 horas. Em seguida, uma solução de $\mathrm{HCl}$ 0,04M em isopropanol foi adicionada em cada poço da microplaca para a solubilização dos sais de formazan, a placa foi incubada novamente por adicionais 24 horas e então procedeu-se a leitura da absorbância a $545 \mathrm{~nm}$.

\subsubsection{Avaliação da Proliferação Celular}

As células NIH-3T3 foram plaqueadas em microplacas de 96 poços de fundo plano, na densidade de $10^{5}$ células (volume de $200 \mu \mathrm{L}$ ), por poço, em triplicata. As placas foram incubadas durante 24 horas a $37^{\circ} \mathrm{C}$ em estufa com $5 \%$ de tensão de $\mathrm{CO}_{2}$ para a obtenção de crescimento confluente. Após este período, observou-se aderência das células e então o volume total do meio de cultura foi aspirado e adicionou-se $200 \mu \mathrm{L}$ das soluções teste contendo óleo-resina de copaíba de forma que as concentrações finais fossem: 1,0;10;50;100; 500 e $1000 \mu \mathrm{g} / \mathrm{mL}$, meio de cultura Iscove (controle) e meio de cultura Iscove acrescido de DMSO, separadamente, em triplicata. As placas foram incubadas a $37^{\circ} \mathrm{C}$ em estufa com $5 \%$ de tensão de $\mathrm{CO}_{2}$ durante 24 horas.

Acrescentou-se $20 \mu \mathrm{L}$ de $\mathrm{H}^{3}$-Timidina ( $1 \mu \mathrm{Ci}$ ) em todos os poços da microplaca e incubou-se nas mesmas condições. Após 16 horas, utilizando-se o equipamento Cell Harvester, o volume de cada poço foi aspirado, 
separadamente, passando por papel de filtro, onde as células ficaram retidas. Os papéis de filtro correspondentes a cada poço/amostra foram transferidos para frascos plásticos contendo $2,0 \mathrm{~mL}$ de líquido de cintilação. O efeito do óleo-resina sobre a proliferação celular foi avaliado pela incorporação da timidina tritiada, tendo sido a radioatividade incorporada pelas amostras medida em CPM (Contagens Por Minuto) pelo equipamento Cintilador Beta.

\subsubsection{ESTUDO 2: Avaliação do potencial cicatrizante do óleo-resina de copaíba em úlceras cutâneas no modelo de orelha de coelho}

\subsubsection{Procedimento cirúrgico}

Os animais foram anestesiados com injeção intramuscular de Ketamina $10 \%(1,5 \mathrm{~mL} / a n i m a l)$ e Xylazina $200 \mathrm{mg} / \mathrm{mL}(1,0 \mathrm{~mL} /$ animal $)$. Após tricotomização das orelhas com máquina depilatória, os coelhos foram posicionados em mesa operatória em decúbito lateral direito e esquerdo para a realização das lesões. Após anti-sepsia da área cirúrgica com álcool 70\%, seis úlceras excisionais circulares foram criadas na superfície dorsal de cada orelha dos coelhos, com diâmetro de 6,0 mm cada, utilizando-se punch cirúrgico para biópsia de pele, segundo metodologia descrita por Mustoe et al. (1991).

\subsubsection{Grupos de tratamento}

Cada animal recebeu um tipo de tratamento em ambas as orelhas, diariamente, durante 21 dias a partir do dia do procedimento cirúrgico. Cada coelho representa um grupo de tratamento, com doze úlceras. Cinco tratamentos tópicos foram efetuados: solução fisiológica (controle), creme base, ou seja, sem qualquer princípio ativo adicionado, creme a $10 \%$ de óleo-resina de copaíba; creme a $25 \%$ de óleo-resina e o óleo-resina puro (in natura). Após aplicação de cada tratamento, foi realizado curativo com gaze e esparadrapo, e utilizou-se 
colar do tipo elizabetano para evitar que os coelhos retirassem os curativos e/ou agredissem os locais ulcerados. As úlceras foram avaliadas nos períodos de 2, 7, 14 e 21 dias após o procedimento cirúrgico. Foram utilizados 10 coelhos, sendo dois coelhos (total de 24 úlceras) para cada tratamento.

\subsubsection{Seguimento clínico-experimental: Captura e Análise de imagem}

A avaliação clínico-fotográfica das lesões foi realizada pela evolução das áreas ulceradas através da captura da imagem com posterior análise e determinação dos índices de cicatrização das úlceras (ICUs) utilizando-se o software Image], nos períodos de 0, 2, 7, 14 e 21 dias após o procedimento cirúrgico, conforme descrito por Caetano et al., (2009) e Minatel et al., (2009).

Para a aquisição das imagens, utilizou-se um aparato de metal que possui duas réguas em sua base e um adaptador para câmera digital localizado a $30 \mathrm{~cm}$ de distância da base. O aparato foi posicionado na margem de cada orelha e as imagens foram capturadas por uma câmera fotográfica digital Olympus FE180 com resolução de 6.0 megapixels, sem a utilização de flash ou zoom, nos períodos acima citados. As imagens foram transferidas para um microcomputador e analisadas pelo software ImageJ (versão 1.45), disponível gratuitamente na rede e desenvolvido por Wayne Rasband do Research Services Branch, U.S. National Institutes of Health - NIH (Bethesda, Maryland - EUA) (Figura 7). Os valores dos ICUs foram determinados utilizando-se as dimensões das áreas iniciais e finais de cada úlcera, de acordo com a fórmula:

$$
\text { ICU }=\frac{\text { Área inicial }- \text { Área Final }}{\text { Área inicial }}
$$

Valores de ICU maiores que zero representam diminuição da área ulcerada, valores menores que zero representam aumento da área e valores iguais a zero representam reepitelização completa (CAETANO et al., 2009; MINATEL et al., 2009). A área inicial corresponde ao dia do procedimento cirúrgico e a área final corresponde ao dia de avaliação, ou seja, 2, 7, 14 e 21 dias. 

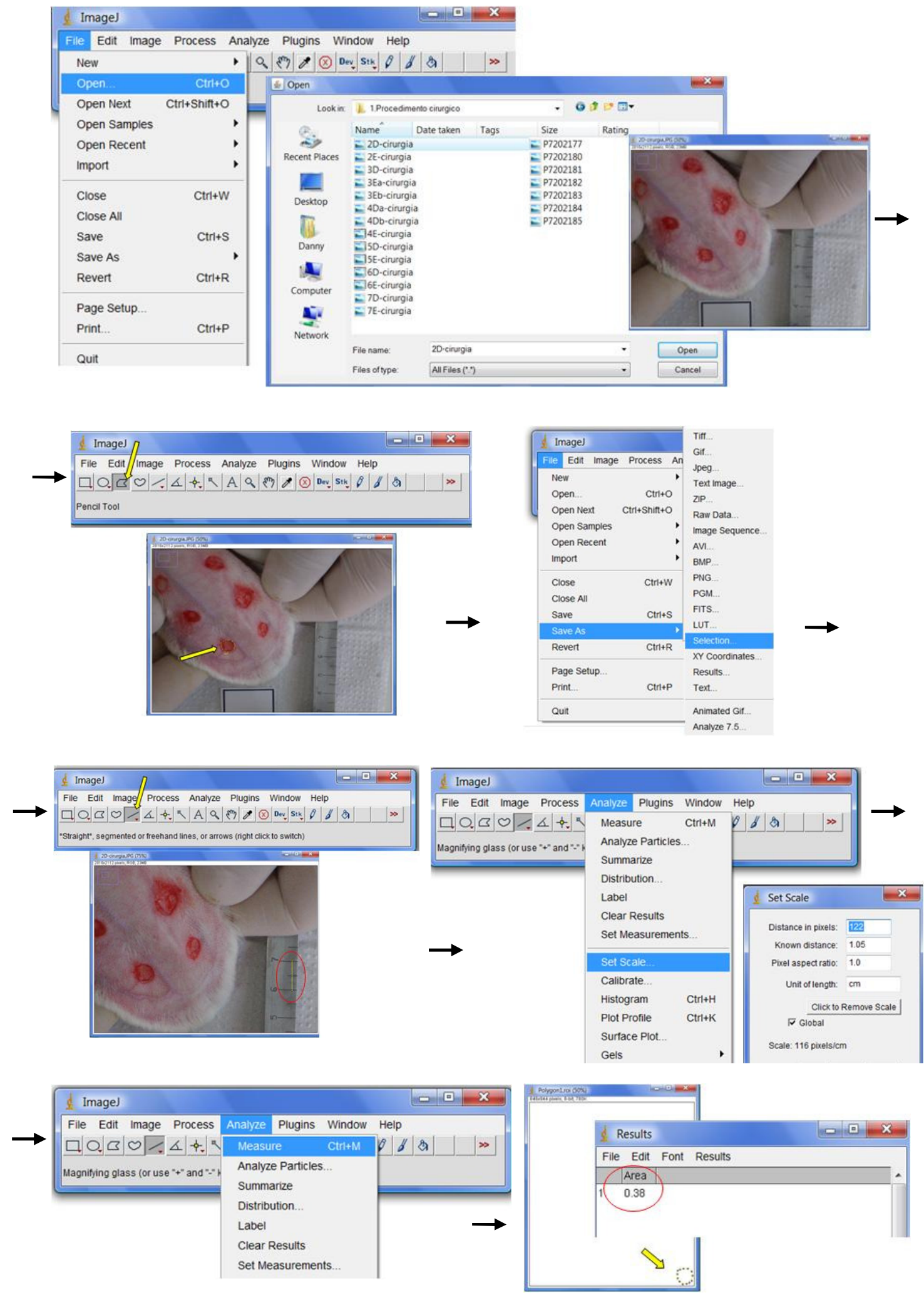

Figura 7 - Representação esquemática do procedimento de análise de imagens para o cálculo das áreas das úlceras pelo software ImageJ para posterior determinação dos valores dos ICUs. 


\subsubsection{Avaliação histopatológica}

Para a avaliação histopatológica, a coleta das biópsias foi realizada nos dias 2, 7, 14 e 21 após o procedimento cirúrgico, mediante anestesia subcutânea perilesional (Lidocaína 2\%), utilizando punch cirúrgico de $6 \mathrm{~mm}$ de diâmetro. Foi colhida uma biópsia de uma lesão por coelho para cada dia de avaliação. Para evitar possível interferência do anestésico no processo cicatricial, padronizou-se colher as biópsias nas orelhas direitas no $2^{\circ}$ e $14^{\circ}$ dias e nas orelhas esquerdas no $7^{\circ}$ e $21^{\circ}$ dias após o procedimento cirúrgico.

Os fragmentos biopsiados foram fixados em solução tamponada de formaldeído $10 \%(\mathrm{v} / \mathrm{v})(\mathrm{pH} \mathrm{7,4)}$ durante 24 horas e posteriormente processados em padrão habitual para estudo histológico. Após o processamento, os fragmentos foram incluídos em parafina a $60^{\circ} \mathrm{C}$ e os blocos foram microtomizados em cortes histológicos de 5,0 $\mu \mathrm{m}$ e então corados pela hematoxilina-eosina (HE), para avaliação da celularidade e pelo tricrômio de Gomori (TG) para avaliação da colagênese.

\subsubsection{ESTUDO 3: Avaliação do potencial cicatrizante do óleo-resina de copaíba em úlceras cutâneas em ratos}

\subsubsection{Procedimento cirúrgico}

Os animais foram anestesiados através da inalação de Isoflurano ( $50 \%$ em propilenoglicol), dentro de um recipiente de vidro hermeticamente fechado, por cerca de 2 a 3 minutos. Antes de iniciar o procedimento cirúrgico, o pêlo do dorso (regiões cervical e torácica) foi removido com máquina depilatória, realizou-se a anti-sepsia da área cirúrgica com álcool isopropílico $70 \%$ e os animais foram posicionados em mesa operatória em decúbito dorsal para a realização das lesões. Quatro úlceras excisionais circulares, com diâmetro de 8,0 $\mathrm{mm}$ cada, foram produzidas utilizando-se punch cirúrgico para biópsia de pele. Durante o procedimento cirúrgico, o plano anestésico foi monitorado através do método de toe pinch e doses subsequentes de anestésico foram administradas 
utilizando um cone nasal contendo um algodão embebido com anestésico, conforme necessário.

\subsubsection{Grupos de tratamento}

Foram utilizados 27 ratos, divididos em três grupos, sendo 9 ratos por grupo de tratamento, com o total de 36 úlceras por grupo. Cada grupo recebeu um tipo de tratamento diariamente, durante 14 dias a partir do dia do procedimento cirúrgico. Três tratamentos tópicos foram efetuados: solução fisiológica, creme base e creme a $10 \%$ de óleo-resina de copaíba. Após aplicação de cada tratamento, gaze estéril foi utilizada como curativo primário e bandagem auto-adesiva como curativo secundário, mantida com esparadrapo. As úlceras foram avaliadas nos períodos de 2, 7 e 14 dias após o procedimento cirúrgico. Para os estudos histológicos e bioquímicos, a cada dia de avaliação e para cada tratamento aplicado, procedeu-se a eutanásia de 3 ratos, e 1 biópsia de cada animal foi colhida para cada teste, ou seja, 3 biópsias para cada teste por dia de avaliação e tratamento.

\subsubsection{Seguimento clínico-experimental: Captura e Análise de imagem}

A avaliação clínico-fotográfica das lesões foi realizada conforme descrito no item 5.2.2.3, entretanto, as imagens foram capturadas após eutanásia dos animais, nos dias 2, 7 e 14 após o procedimento cirúrgico. Os ratos foram posicionados em decúbito dorsal na base do aparato, as imagens foram capturadas, transferidas para um microcomputador, analisadas pelo software Image] e os valores dos ICUs foram determinados.

\subsubsection{Avaliação histopatológica}

Para a avaliação histopatológica, a coleta das biópsias foi realizada nos dias 2, 7 e 14 após o procedimento cirúrgico. Os ratos foram sacrificados por 
overdose de anestésico (isoflurano) e as biópsias foram colhidas utilizando punch cirúrgico de $8,0 \mathrm{~mm}$ de diâmetro. Parte dos fragmentos biopsiados foi fixada em solução tamponada de formaldeído 10\% (v/v) $(\mathrm{pH} 7,4)$ durante 24 horas e posteriormente processados, conforme descrito no item 5.2.2.4.

\subsubsection{Avaliação Bioquímica: Dosagem de Hidroxiprolina}

A análise quantitativa da colagênese foi realizada através da dosagem de hidroxiprolina nas biópsias colhidas dos ratos, seguindo a metodologia proposta por Reddy e Enwemeka (1996), com algumas modificações. As biópsias foram colhidas, conforme previamente descrito, imediatamente congeladas e mantidas à temperatura de $-80^{\circ} \mathrm{C}$ até o momento do teste. As soluções utilizadas nos testes estão apresentadas no APÊNDICE A.

Para a realização das dosagens de hidroxiprolina, as biópsias foram descongeladas e incubadas em estufa com circulação de ar à temperatura de $60^{\circ} \mathrm{C}$ (Supermatec oven - Hotpack, Philadelphia, Pensilvânia - EUA) em microtubos abertos, overnight (padronizando-se cerca de 15 horas por amostra). Após a incubação, as amostras foram pesadas em balança analítica até a obtenção de peso constante e então, foram transferidas para tubos tipo Falcon (NAYAK et al., 2009; SHIVARE et al., 2010). Volumes de ácido clorídrico $(\mathrm{HCl}) 6 \mathrm{~N}$ foram adicionados, utilizando-se a proporção de $100 \mu \mathrm{L}$ de $\mathrm{HCl}$ por $1,0 \mathrm{mg}$ de tecido seco (EDWARDS e O'BRIEN, 1980). As amostras foram homogeneizadas, por 10 segundos, com o homogenizador de tecidos Polytron (Polytron Homogenizer. Kinematica AG. Suíça) e então submetidas à hidrólise ácida, que consistiu na incubação das amostras em $\mathrm{HCl}$ a $130^{\circ} \mathrm{C}$ durante 4 horas (Gravity convention oven - Precision, GCA Corporation. EUA) (REDDY et al., 2008; SHIVARE et al., 2010).

Após o período de hidrólise e com as amostras à temperatura ambiente, transferiu-se $500 \mu \mathrm{L}$ de cada amostra para um tubo de ensaio de vidro, onde verificou-se e ajustou-se o pH para 7,0, com hidróxido de sódio $(\mathrm{NaOH}) 2 \mathrm{M}$. A partir deste hidrolisado, com $\mathrm{pH}$ neutro, pipetou-se $10 \mu \mathrm{L}$ para uma microplaca de 96 poços. Foram preparadas soluções-padrão de hidroxiprolina nas concentrações de 1,$0 ; 2,0 ; 4,0 ; 6,0 ; 8,0 ; 10 ; 20 ; 40 ; 60 ; 80$ e $100 \mu \mathrm{g} / \mathrm{mL}$, usando-se o tampão Citrato-Acetato $\mathrm{pH}$ 6,5 como veículo e como branco, à partir das quais pipetou-se 
$10 \mu \mathrm{L}$ na microplaca. Adicionou-se $90 \mu \mathrm{L}$ de solução de Chloramina T 0,056M a cada poço e incubou-se a microplaca, à temperatura ambiente durante 25 minutos (REDDY et al., 2008; REDDY; ENWEMEKA, 1996; XIE et al., 2008).

Ao final da incubação, as amostras oxidadas foram então submetidas a adição de $100 \mu \mathrm{L}$ do reagente de Ehrlich para a formação do cromóforo. A microplaca foi incubada a $60^{\circ} \mathrm{C}$ durante 20 minutos (REDDY e ENWEMEKA, 1996; SHIVARE et al., 2010).

Após a incubação, as microplacas foram homogeneizadas em um homogeneizador para microplacas (Labnet Orbit P4, EUA) a 20 rpm durante 10 minutos. Quando as placas encontravam-se à temperatura ambiente, realizou-se

a leitura da absorbância a $550 \mathrm{~nm}$ [Multi-detection Microplate reader (Synergy ${ }^{\mathrm{TM}}$ $H T$, Biotek. EUA)] As leituras foram realizadas em períodos não superiores a 30 minutos após o final da incubação. O teste foi realizado em triplicata tanto para as amostras quanto para as soluções-padrão de hidroxiprolina, e a curva padrão foi realizada simultaneamente em todas as microplacas analisadas.

Os valores das absorbâncias foram plotados, determinou-se a equação da reta e comparando as absorbâncias das concentrações conhecidas da curva padrão de hidroxiprolina com as absorbâncias das amostras, determinou-se as concentrações de hidroxiprolina nas amostras, primeiramente por volume de $\mathrm{HCl}$ usado e finalmente por miligrama de tecido seco.

\subsubsection{Avaliação Bioquímica: Dosagem de Metaloproteinases}

\subsection{Preparo das amostras}

As biópsias, que estavam armazenadas à temperatura de $-80^{\circ} \mathrm{C}$, foram pesadas para a determinação do peso úmido. Em seguida, em banho de gelo, em uma placa de vidro, as amostras foram seccionadas com bisturi e colocadas em tubo de ensaio de vidro contendo tampão para homogeneização. O tampão constituiu-se de: Tris- $\mathrm{HCl} 0,05 \mathrm{M}, \mathrm{NaCl} 0,2 \mathrm{M}, \mathrm{CaCl}_{2} 5 \mathrm{mM}$ e 0,1\% de Triton X100 , com valor de $\mathrm{pH}$ igual a 7,4. O volume de tampão foi de $1,0 \mathrm{~mL}$ para cada $50 \mathrm{mg}$ de tecido. As amostras foram homogeneizadas com o auxílio do 
homogeneizador de tecidos Polytron na velocidade de $25.000 \mathrm{rpm}$ durante 20 segundos, por duas vezes. O tecido homogeneizado foi transferido para microtubo e centrifugado a $8000 \mathrm{xg}$, a $4^{\circ} \mathrm{C}$ durante 20 minutos (Centrifuge Hermle Z300K, Wehingen - Alemanha). O sobrenadante foi colhido e alíquotas de $500 \mu \mathrm{L}$ foram armazenadas a $-80^{\circ} \mathrm{C}$ até o momento do uso (INOMATA et al., 2003). O sobrenadante será a partir de agora descrito como homogenato.

\subsection{Dosagem de proteínas}

A concentração de proteínas totais para cada biópsia (homogenato) foi determinada pelo método colorimétrico de Bradford através do kit Cayman's Protein Determination (Cayman Chemical. Ann Harbor, Michigan - EUA), em microplacas de 96 poços.

Os reagentes e os padrões foram preparados e mantidos conforme recomendação do fabricante. A curva padrão foi determinada utilizando-se as concentrações de 0,$0 ; 5,6 ; 7,5 ; 10,1 ; 13,3 ; 18,0 ; 24,0 ; 32,0$ e $40,0 \mu \mathrm{g} / \mathrm{mL}$ de albumina de soro bovino (BSA) que acompanhava o kit. Cada homogenato foi diluído pelo fator 100 em água deionizada (10 $\mu \mathrm{L}$ do homogenato e $990 \mu \mathrm{L}$ de água). O volume de $100 \mu \mathrm{L}$ de cada solução padrão foi pipetado na microplaca, seguido pela adição de mesmo volume das amostras diluídas. Em seguida, pipetou-se $100 \mu \mathrm{L}$ do reagente. As microplacas foram incubadas durante 5 minutos à temperatura ambiente.

As medidas das absorbâncias foram realizadas a $595 \mathrm{~nm}$ (Multi-detection Microplate reader (Synergy ${ }^{\mathrm{TM}} \mathrm{HT}$, Biotek, EUA). O teste foi realizado em duplicata, e a curva padrão foi realizada simultaneamente em todas as microplacas analisadas.

\subsection{Zimografia em gelatina}

A partir da determinação da concentração de proteínas nos homogenatos, calculou-se o volume equivalente de cada amostra (homogenato) a conter $20 \mu \mathrm{g}$ 
de proteínas totais, a ser utilizado para a zimografia (ADHIRAJAN et al., 2009). As soluções utilizadas nos testes estão apresentadas no APÊNDICE B.

A primeira etapa para a determinação das metaloproteinases consistiu em eletroforese dos homogenatos em gel de poliacrilamida SDS-PAGE 10\%, contendo $1,0 \mathrm{mg} / \mathrm{mL}$ de gelatina como substrato enzimático. Foram utilizados géis prontos (BioRad, Cat. 161-1185, Richmond, Califórnia - EUA). Os géis foram designados de maneira que cada um contivesse amostras dos três grupos de tratamento, em todos os dias de seguimento para cada condição (úlceras nãoinfectadas, infectadas com S. aureus e infectadas com S. pyogenes) (Figura 8). Para cada grupo, 3 biópsias de 3 ratos foram colhidas por dia de avaliação e tratamento. Desta forma, foi possível fazer os géis em triplicata.

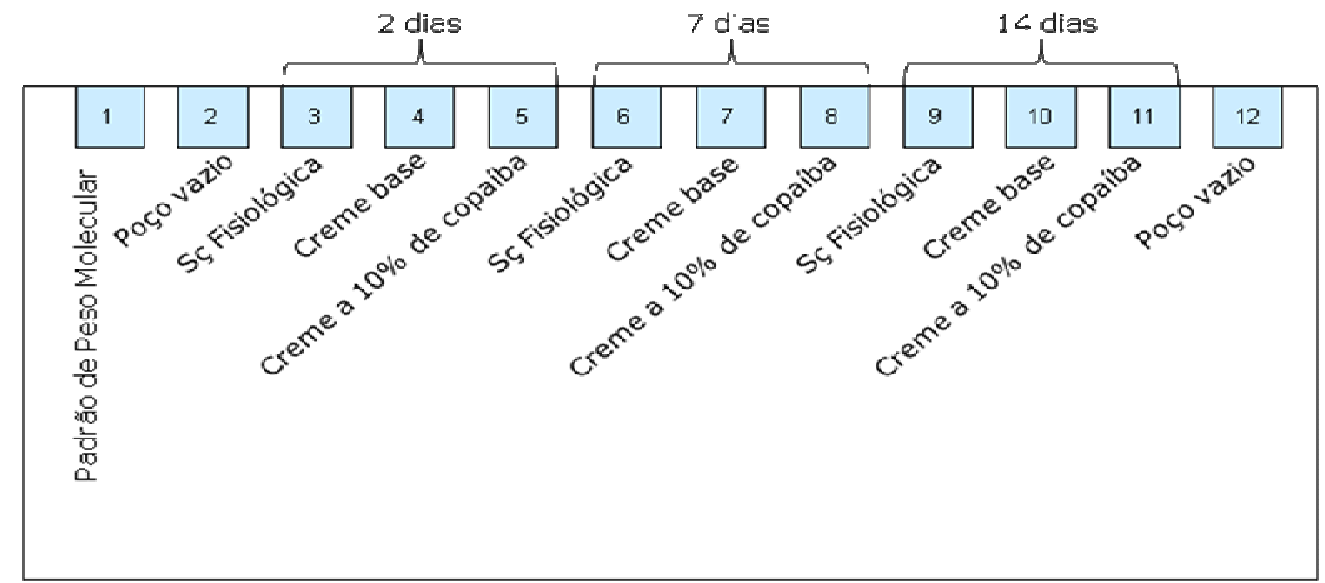

Figura 8 - Representação esquemática da disposição das amostras nos géis de zimografia.

Os géis foram posicionados em aparato para eletroforese (Mini-Protean, BioRad, Richmond, Califórnia - EUA) conforme instruções do fabricante e adicionou-se $700 \mathrm{~mL}$ do tampão de corrida. Preparou-se as amostras, diluindo uma parte de homogenato para uma parte de tampão para as amostras (ADHIJARAN et al., 2009; LADWIG et al., 2002). Em seguida, $20 \mu \mathrm{L}$ do padrão de peso molecular (Novex ${ }^{\circledR}$ Sharp Unstained Protein Standard, Invitrogen, Carlsbad, Califórnia - EUA) e os volumes correspondentes a cada amostra, contendo $20 \mu \mathrm{g}$ de proteína por poço, foram pipetados no gel. A corrente elétrica foi ajustada para $100 \mathrm{~V}$, durante 90 minutos. Este tempo pode variar e mantémse a corrente até que seja possível observar que as bandas tenham atingido a base do gel. O teste foi realizado à temperatura de $4^{\circ} \mathrm{C}$. 
Ao final do período de corrida, os géis foram retirados do aparato e do cassete que os continha, transferidos para uma caixa de acrílico para géis e lavados com o tampão de renaturação para a remoção do SDS, por três vezes de 15 minutos cada, em agitador orbital, permitindo que as enzimas se renaturem e possam degradar o substrato protéico. Em seguida, os géis foram lavados com tampão de desenvolvimento, por 5 minutos. Novo volume deste último tampão foi adicionado aos géis que foram incubados a $37^{\circ} \mathrm{C}$, durante 16 horas (DACHIR et al., 2010; LADWIG et al., 2002; TANG et al., 2009).

Ao final do período de incubação, os géis foram lavados com a solução corante e em seguida incubados, em placa de Petri, com esta solução, à temperatura ambiente, durante 1 hora, em agitador orbital. Os géis foram descorados com solução descorante até que fosse possível observar bandas claras/descoradas indicativas da atividade enzimática, em torno de 60 a 90 minutos, trocando-se a solução a cada 30 minutos (RAYMENT; UPTON; SHOOTER, 2008).

Os géis foram lavados com água deionizada três vezes por 2 minutos, sob agitação. Em seguida, adicionou-se a solução para secagem e os géis foram incubados à temperatura ambiente durante 4 minutos. Neste momento, preparou-se o molde de acrílico: colocou-se 1 folha de celofane, umedecida na solução para secagem, sobre o molde, o gel e em seguida outra folha de celofane e a segunda parte do molde. Com o auxílio de clipes pressionou-se o "sanduíche" celofane-gel-celofane e aguardou-se até que o mesmo estivesse seco (em torno de 24 horas).

Os géis secos foram removidos do molde e imagens digitais foram obtidas com o auxílio de um scanner. Padronizou-se que todas as imagens tivessem a resolução de 300 dpi e fossem salvas no formato tiff. Com a aquisição das imagens, procedeu-se à densitometria para a quantificação das bandas de digestão enzimática observadas nos géis, utilizando-se o software Image] (HU; BEETON, 2010), conforme representado na Figura 9. A identificação das metaloproteinases foi feita de acordo com os pesos moleculares do padrão adicionado a cada gel de zimografia e a atividade enzimática foi quantificada pela determinação da área dos picos, representando a intensidade das bandas de cada protease. 

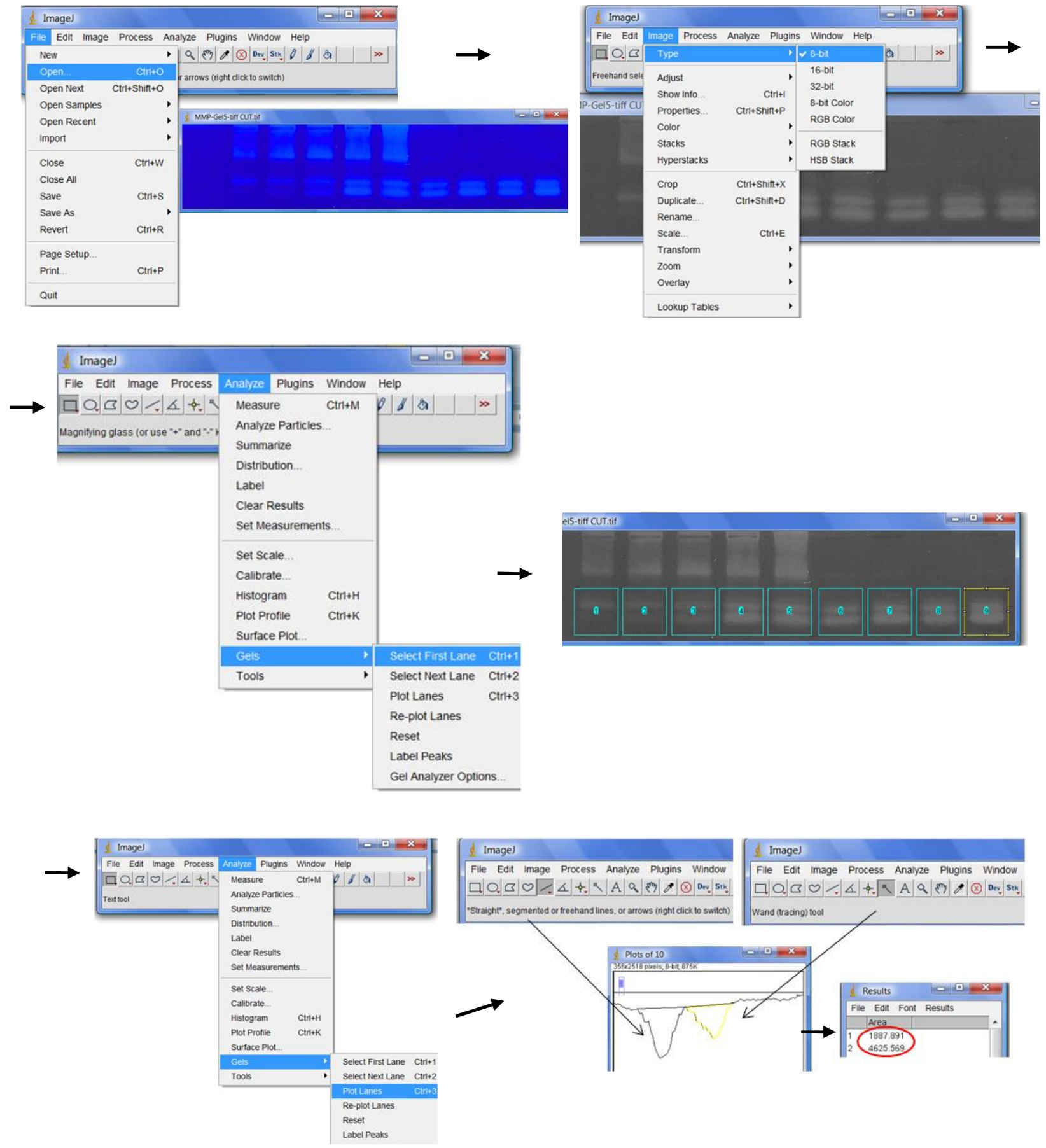

Figura 9 - Representação esquemática do procedimento de análise das bandas de digestão enzimática (densitometria) nos géis de zimografia em gelatina pelo software ImageJ. 


\subsubsection{ESTUDO 4: Efeito do óleo-resina de copaíba no modelo ex vivo de cicatrização da pele humana (culturas organotípicas de explantes de pele humana)}

\subsubsection{Obtenção e Cultura de pele}

Fragmentos de pele humana, saudáveis, descartados de cirurgias plásticas realizadas no HCRP-FMRP-USP, após o consentimento dos pacientes, foram utilizados para a cultura. Após a remoção do excesso de tecido gorduroso subcutâneo e da derme profunda, a pele foi seccionada em fragmentos com dimensões de $1,0 \mathrm{~cm}^{2}$. Em seguida, foi criada uma úlcera excisional circular com diâmetro de 4,0 mm utilizando-se punch cirúrgico para biópsia de pele em cada fragmento. Os fragmentos foram então posicionados com o lado dérmico sobre papel de filtro apoiado em grades metálicas em placas de cultura de 6 poços e a epiderme permaneceu acima da interface meio/ar. Foi adicionado o meio de cultura Dubelcco's Modified Eagle Medium (DMEM) suplementado com $10 \%$ de soro bovino fetal e $1 \%$ de solução de antibiótico (penicilina $100 \mathrm{U} / \mathrm{mL}$, estreptomicina $100 \mathrm{mg} / \mathrm{mL}$ ). O número de placas de cultura foi planejado para permitir que houvesse fragmentos a serem colhidos durante os 21 dias de avaliação para cada tratamento aplicado (Figura 10).

O tratamento consistiu da aplicação tópica diária do óleo-resina de copaíba in natura $(5,0 \mu \mathrm{L})$, cremes a $10 \%$ e $25 \%$ de óleo-resina de copaíba, creme base, e o próprio meio de cultura (DMEM), como controle, durante 21 dias. O óleo-resina puro foi aplicado com pipeta e os cremes foram aplicados com espátula estéril. As placas foram mantidas a $37^{\circ} \mathrm{C}$ em estufa com $5 \%$ de tensão de $\mathrm{CO}_{2}$. O meio de cultura foi trocado a cada três dias. Os testes foram realizados em triplicata, utilizando 21 placas, sendo 7 placas por paciente ou pele. Metodologia adaptada de JACOBS et al., 2002.

Todo o material empregado na realização das culturas, incluindo material cirúrgico, vidrarias, frascos, pipetas e ponteiras, foi devidamente esterilizado e todos os procedimentos foram executados assepticamente, dentro de capela com fluxo laminar. 


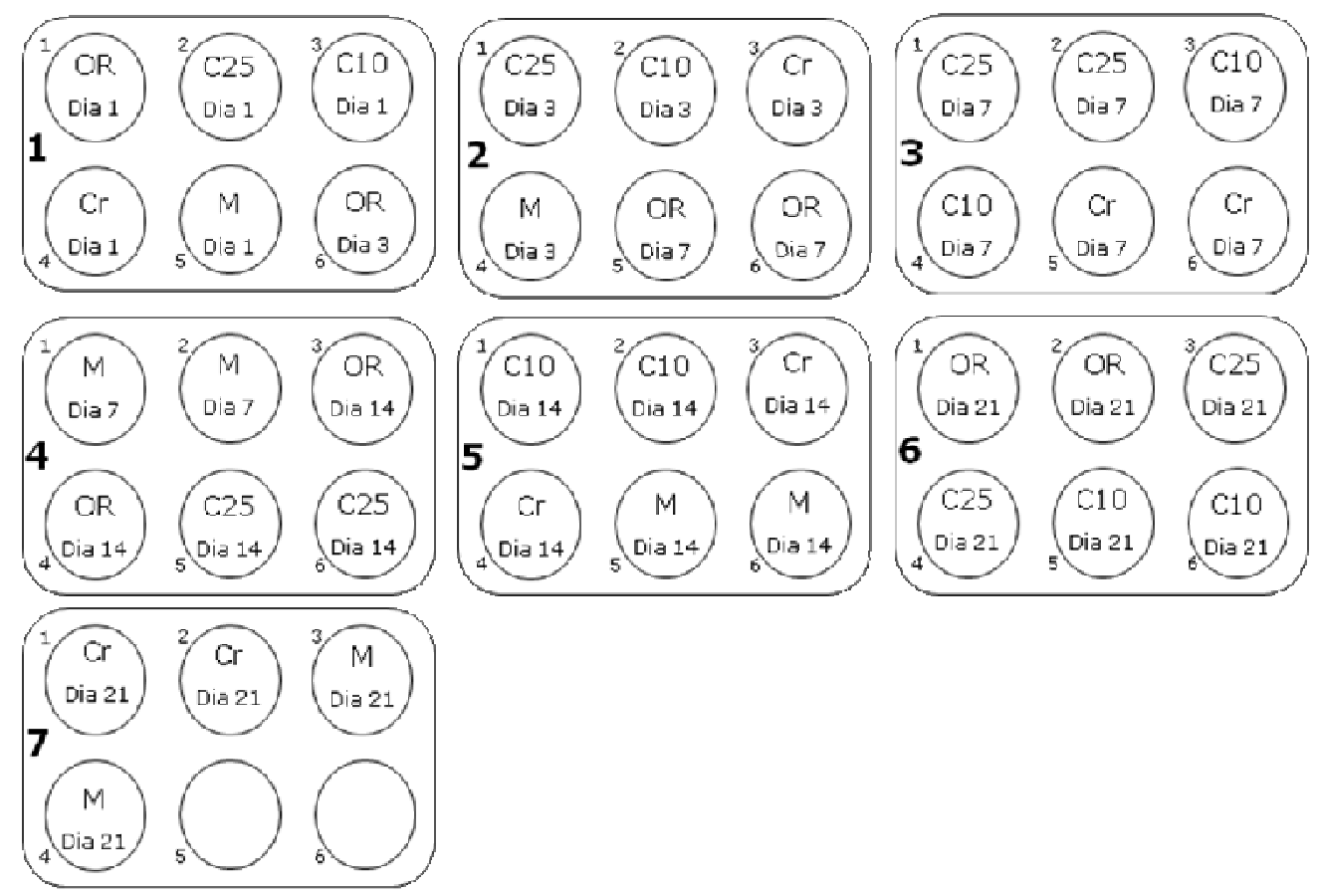

Figura 10 - Representação das placas de cultura de pele e da padronização dos tratamentos aplicados aos fragmentos: Óleo-resina in natura (OR); Cremes a 25\% (C25) e a 10\% do óleoresina de copaíba (C10); creme base (Cr); meio de cultura (DMEM) (M). Os dias descritos representam o período no qual o fragmento foi colhido da placa para avaliação.

\subsubsection{Avaliação}

Nos dias $0,1,3,7,14$ e 21, todas as placas de cultura foram fotografadas e fragmentos correspondentes a cada tratamento foram removidos das placas e fixados em solução tamponada de formaldeído $10 \%(\mathrm{v} / \mathrm{v})(\mathrm{pH} 7,4)$ durante 24 horas e posteriormente processados em padrão habitual para estudo histológico. Além da observação de alterações macroscópicas no tecido por captura de imagem, as características morfológicas dos fragmentos foram avaliadas pela coloração por HE.

\subsubsection{ESTUDO 5: Avaliação da atividade antimicrobiana in vitro do óleo- resina de copaíba.}

A atividade antimicrobiana do óleo-resina de copaíba foi avaliada frente a cepas padrão ATCC (American Type of Culture Collection) de bactérias Gram- 
positivas e Gram-negativas frequentemente encontradas na prática clínica em pacientes com úlceras cutâneas infectadas: Staphylococcus aureus (ATCC 6538), Streptococcus pyogenes (ATCC 19615), Enterococcus faecalis (ATCC 10541), Pseudomonas aeruginosa (ATCC 2327) e Escherichia coli (ATCC 10538).Os microrganismos foram gentilmente cedidos pelo professor Dr. Sérgio L. Salvador, do Laboratório de Microbiologia do Departamento de Análises Clínicas, Toxicológicas e Bromatológicas da Faculdade de Ciências Farmacêuticas de Ribeirão Preto, USP.

\subsubsection{Meios de cultura}

Diversos meios de cultura foram preparados, de acordo com as instruções dos fabricantes, em função do microrganismo avaliado e das condições de avaliação.

O meio de cultura caldo BHI (Brain Heart Infusion) (Difco) caldo foi preparado de maneira que a concentração final do mesmo estivesse em 3,7\% em água destilada. Quando usou-se o meio BHI suplementado com 1,0\% glicose, esta foi acrescentada durante a etapa de preparação do meio de cultura. Para o preparo de BHI ágar, adicionou-se 1,5\% de ágar (Ágar-ágar-Difco) durante a preparação do BHI caldo. O meio de cultura Água peptonada (Peptone water) (Difco) foi preparado a $2,5 \%$ em água destilada e o meio Caldo nutriente (Nutrient broth) (Difco) a 8,0\% em água destilada.

O meio de cultura Tioglicolato sem dextrose ou indicador (Thioglycollate Medium without dextrose or indicator) (Difco) foi preparado a 2,4\% em água destilada. O meio de cultura caldo Mueller-Hinton (MH) (Difco) foi preparado a $2,1 \%$ em água destilada, e para o preparo de $\mathrm{MH}$ ágar, acrescentou-se 1,5\% de Ágar-ágar (Difco) durante o preparo. Também preparou-se solução fisiológica na concentração de $0,9 \%$ de cloreto de sódio em água destilada.

Imediatamente após a pesagem e homogeneização dos meios de cultura e do cloreto de sódio em água destilada, todas as soluções foram autoclavadas (Autoclave vertical - Phoenix) durante 20 minutos à temperatura de $120^{\circ} \mathrm{C}$ e pressão de vapor a $1,0 \mathrm{Kgf} / \mathrm{cm}^{2}$. 
O meio BHI ágar, ainda líquido, foi vertido em placas de Petri (150 mm de diâmetro) de vidro estéreis após arrefecimento até aproximadamente $50^{\circ} \mathrm{C}$, dentro de capela com fluxo laminar. Para preparar o meio $\mathrm{MH}$ ágar inclinado, o meio ainda líquido e após arrefecimento até aproximadamente $50^{\circ} \mathrm{C}$ foi colocado em tubos de ensaio de vidro estéreis posicionados de maneira inclinada sobre um suporte.

\subsubsection{Cultivo dos microrganismos}

As bactérias foram cultivadas por um período de três dias antes da realização das curvas de crescimento bacteriano, realizada para a determinação da fase exponencial de crescimento, ou seja, período em que os microrganismos expressam ao máximo os seus caracteres fisiológicos.

As cepas de $S$. aureus, $P$. aeruginosa e E. coli estavam previamente semeadas em ágar $\mathrm{MH}$, a cepa de $E$. faecalis estava semeada em meio tioglicolato, todas à temperatura ambiente; a cepa de S.pyogenes estava congelada em glicerol e meio de cultura à temperatura de $-20^{\circ} \mathrm{C}$

Para as bactérias: S. aureus, P. aeruginosa e E.coli o seguinte protoloco foi realizado: no $1^{0}$ dia, procedeu-se a renovação da cultura, ou seja, a partir do meio de manutenção inclinado $\mathrm{MH}$ ágar, semeou-se com alça de platina em outro tubo de ensaio de vidro contendo o mesmo meio de cultura. Após 24 horas de incubação à temperatura ambiente, uma alçada de microrganismos foi semeada em 5,0 $\mathrm{mL}$ de meio $\mathrm{MH}$ caldo e a cultura foi incubada a $37^{\circ} \mathrm{C}$ (Estufa Bacteriológica Tecnal - Mod. TE-392/I) durante 24 horas. No 30 dia, o volume de $100 \mu \mathrm{L}$ desta cultura foi transferido para outro tubo contendo $10,0 \mathrm{~mL}$ de meio $\mathrm{MH}$ caldo, que foi incubado a $37^{\circ} \mathrm{C}$, durante 24 horas.

Para o S. pyogenes e E. faecalis desde o $1^{\circ}$ dia utilizou-se o meio líquido tioglicolato sem dextrose ou indicador. Partiu-se da transferência de $300 \mu \mathrm{L}$ dos meios de cultura originais para $10,0 \mathrm{~mL}$ de um novo meio tioglicolato no $1^{\circ}$ dia e incubou-se $37^{\circ} \mathrm{C}$. Após 24 horas de incubação, transferiu-se $100 \mu \mathrm{L}$ da cultura para 5,0 $\mathrm{mL}$ de um novo meio tioglicolato e procedeu-se nova incubação $\left(37^{\circ} \mathrm{C} / 24\right.$ horas). No $3^{\circ} \mathrm{dia}$, o volume de $100 \mu \mathrm{L}$ desta cultura foi transferido 
para outro tubo contendo $10,0 \mathrm{~mL}$ de meio tioglicolato que foi incubado a $37^{\circ} \mathrm{C}$, durante 24 horas.

\subsubsection{Determinação da curva de crescimento bacteriano}

Para a realização da curva de crescimento bacteriano, 24 horas após incubação nas condições e meios de cultura anteriormente descritos, que corresponde ao $4^{\circ}$ dia de cultivo, transferiu-se o volume de 5,0 mL de cada cultura bacteriana para um balão volumétrico contendo $200 \mathrm{~mL}$ (ou seja, 2,5\% $\mathrm{v} / \mathrm{v}$ ) de meio de cultura específico para cada microrganismo. No entanto, antes de adicionar a suspensão bacteriana ao meio de cultura, determinou-se a absorbância de uma alíquota de $1,0 \mathrm{~mL}$ apenas de cada meio de cultura (branco), correspondente ao tempo zero de incubação (Espectrofotômetro Spectronic $^{\circledR} 20$ Genesys $^{\circledR}$ ), assim como a absorbância de cada cultura. As culturas bacterianas foram então adicionadas aos meios de cultura e imediatamente incubadas a $37^{\circ} \mathrm{C}$, sob agitação de $100 \mathrm{rpm}$ (Incubadora Shaker Marconi- Mod. MA420). A absorbância das amostras foi determinada ao final de cada hora de incubação, retirando-se $1,0 \mathrm{~mL}$ da solução.

\subsubsection{Determinação da Concentração Inibitória Mínima (CIM)}

\subsection{Preparo das soluções estoque de óleo-resina de copaíba}

Quantidades específicas de óleo-resina de copaíba foram solubilizadas em dimetilsulfóxido (DMSO) e volumes apropriados de meio de cultura BHI foram acrescentados para a obtenção de soluções com concentrações finais de 4,0; 5,0; 10 e 15 mg/mL de óleo-resina (Quadro 1 ). 
Quadro 1 - Soluções de óleo-resina de copaíba para os testes de sensibilidade bacteriana.

\begin{tabular}{|c|c|}
\hline Solução 1 (4,0 mg/mL) (S1) & Solução $2(5,0 \mathrm{mg} / \mathrm{mL})(\mathbf{S 2})$ \\
\hline Óleo-resina .......................... 0,04 g & Óleo-resina ......................... 0,05 g \\
\hline 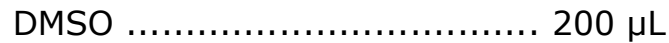 & 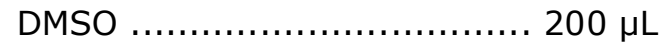 \\
\hline BHI com DMSO $(2,0 \%) \ldots$ qsp* $10 \mathrm{~mL}$ & BHI com DMSO $(2,0 \%) \ldots$ qsp* $10 \mathrm{~mL}$ \\
\hline Solução $3(10 \mathrm{mg} / \mathrm{mL})(\mathbf{S 3})$ & Solução 4 (15 mg/mL) (S4) \\
\hline Óleo-resina $\ldots \ldots \ldots \ldots \ldots \ldots \ldots \ldots \ldots \ldots \ldots \ldots \ldots \ldots, 10 \mathrm{~g}$ & Óleo-resina $\ldots \ldots \ldots \ldots \ldots \ldots \ldots \ldots \ldots \ldots \ldots \ldots \ldots, 15 \mathrm{~g}$ \\
\hline DMSO & 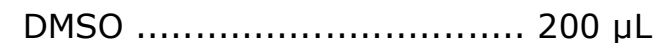 \\
\hline BHI com DMSO $(2,0 \%) \ldots$. qsp* $10 \mathrm{~mL}$ & BHI com DMSO $(2,0 \%) \ldots$. qsp* $10 \mathrm{~mL}$ \\
\hline
\end{tabular}

*qsp: quantidade suficiente para

\section{2}

Após a determinação do meio de cultura mais adequado para que cada microrganismo atingisse a fase log (crescimento exponencial), o procedimento descrito para o cultivo e para a obtenção da curva de crescimento foi repetido. $\mathrm{Na}$ metade da fase log (crescimento exponencial), colheu-se duas alíquotas de $1,0 \mathrm{~mL}$ em microtubos de polietileno. Centrifugou-se as amostras a $11500 \times \mathrm{g}$ à temperatura ambiente, durante 2 minutos (Centrífuga Eppendorf 5810-R). O sobrenadante foi descartado e adicionou-se $100 \mu \mathrm{L}$ de solução fisiológica estéril para ressuspender o pellet formado. Este inóculo foi utilizado para o preparo de uma suspensão padronizada de células bacterianas com turbidez correspondente à escala 0,5 de McFarland. Em 3,0 mL de solução fisiológica estéril, adicionou-se aos poucos o inóculo, e verificou-se a escala em um densímetro (Densimat, bioMérieux). Com a obtenção do inóculo, partiu-se para uma série de diluições decimais: pipetou-se $1,0 \mathrm{~mL}$ do inóculo $\left(10^{8}\right.$ unidades formadoras de colônia (UFC)/mL) em um tubo de ensaio contendo $9,0 \mathrm{~mL}$ de solução fisiológica e a partir deste, pipetou-se 1,0 mL em outro tubo contendo 9,0 mL de solução fisiológica (Figura 11). O procedimento foi repetido até a obtenção de 
aproximadamente $10^{5} \mathrm{UFC} / \mathrm{mL}$, que foi 0 inóculo padronizado para a determinação da concentração inibitória mínima.

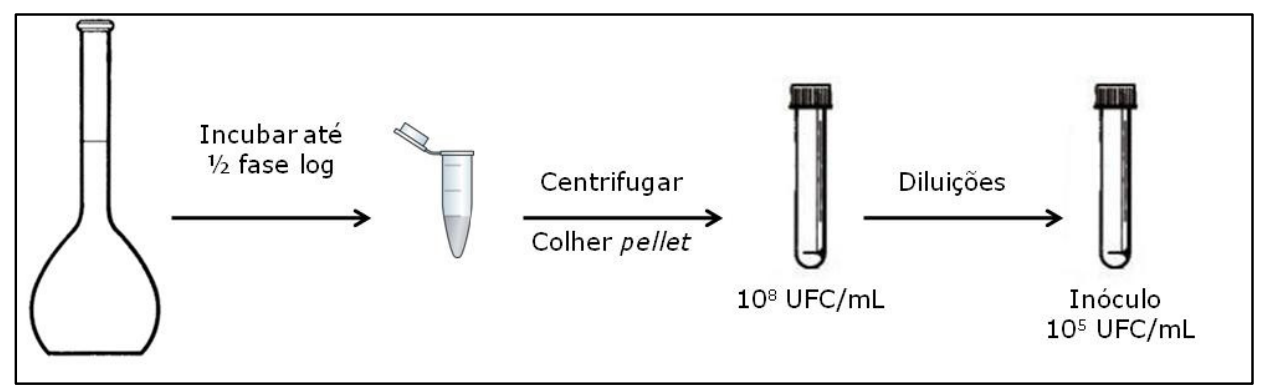

Figura 11 - Representação esquemática do procedimento para a obtenção do inóculo a ser utilizado para os testes de sensibilidade bacteriana.

\subsection{Microdiluições e subcultura dos microrganismos}

A determinação da concentração inibitória mínima (CIM) do óleo-resina de copaíba foi realizada em microplacas de cultivo com 96 poços de fundo plano e dois dos protocolos estão apresentados nos Quadros 2 e 3. Testou-se também microdiluições variando de $1,5 \mathrm{mg} / \mathrm{mL}$ a $3,2 \mu \mathrm{g} / \mathrm{mL}$ e $2,0 \mathrm{mg} / \mathrm{mL}$ a $6,25 \mu \mathrm{g} / \mathrm{mL}$. 
Quadro 2 - Protocolo de preparo da microplaca de cultivo para a determinação da concentração inibitória mínima do óleo-resina de copaíba.

\begin{tabular}{|c|c|c|c|c|c|c|c|c|c|c|c|c|}
\hline & & & & & & & & & & & & \\
\hline & 1 & 2 & 3 & 4 & 5 & 6 & 7 & 8 & 9 & 10 & 11 & 12 \\
\hline [] & $1,0 \mathrm{mg} / \mathrm{mL}$ & $0,8 \mathrm{mg} / \mathrm{mL}$ & $0,6 \mathrm{mg} / \mathrm{mL}$ & $0,4 \mathrm{mg} / \mathrm{mL}$ & $0,2 \mathrm{mg} / \mathrm{mL}$ & $0,1 \mathrm{mg} / \mathrm{mL}$ & $0,05 \mathrm{mg} / \mathrm{mL}$ & $25 \mu \mathrm{g} / \mathrm{mL}$ & $12,5 \mu \mathrm{g} / \mathrm{mL}$ & $6,25 \mu \mathrm{g} / \mathrm{mL}$ & $3,125 \mu \mathrm{g} / \mathrm{mL}$ & $1,6 \mu \mathrm{g} / \mathrm{mL}$ \\
\hline A & $\begin{array}{l}50 \mu \mathrm{L} \text { S2 } \\
200 \mu \mathrm{L} \text { inóc. }\end{array}$ & $\begin{array}{l}50 \mu \mathrm{L} \text { S1 } \\
200 \mu \mathrm{L} \text { inóc. }\end{array}$ & $\begin{array}{l}20 \mu \mathrm{L} \text { BHI } \\
30 \mu \mathrm{L} \mathrm{S} 2 \\
200 \mu \mathrm{L} \text { inóc. }\end{array}$ & $\begin{array}{l}50 \mu \mathrm{L} \mathrm{BHI} \\
50 \mu \mathrm{L} \mathrm{S1} \\
200 \mu \mathrm{L} \text { inóc. }\end{array}$ & $\begin{array}{c}50 \mu \mathrm{LBHI} \\
200 \mu \mathrm{L} \text { inóc. }\end{array}$ & $\begin{array}{c}50 \mu \mathrm{L} \text { BHI } \\
200 \mu \mathrm{L} \text { inóc. }\end{array}$ & $\begin{array}{c}50 \mu \mathrm{L} \text { BHI } \\
200 \mu \mathrm{L} \text { inóc. }\end{array}$ & $\begin{array}{c}50 \mu \mathrm{L} \text { BHI } \\
200 \mu \mathrm{L} \text { inóc. }\end{array}$ & $\begin{array}{c}50 \mu \mathrm{L} \text { BHI } \\
200 \mu \mathrm{L} \text { inóc. }\end{array}$ & $\begin{array}{c}50 \mu \mathrm{LBHI} \\
200 \mu \mathrm{L} \text { inóc. }\end{array}$ & 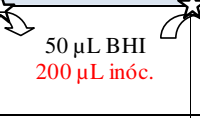 & $\begin{array}{l}50 \mu \mathrm{L} \mathrm{BHI} \\
200 \mu \mathrm{L} \text { inóc. }\end{array}$ \\
\hline B & $\begin{array}{l}50 \mu \mathrm{L} \text { S2 } \\
200 \mu \mathrm{L} \text { inóc. }\end{array}$ & $\begin{array}{l}50 \mu \mathrm{LS} 1 \\
200 \mu \mathrm{L} \text { inóc. }\end{array}$ & $\begin{array}{l}20 \mu \mathrm{L} \text { BHI } \\
30 \mu \mathrm{L} \mathrm{S} 2 \\
200 \mu \mathrm{L} \text { inóc. }\end{array}$ & $\begin{array}{l}50 \mu \mathrm{L} \text { BHI } \\
50 \mu \mathrm{L} \mathrm{S1} \\
200 \mu \mathrm{L} \text { inóc. }\end{array}$ & $\begin{array}{l}50 \mu \mathrm{L} \text { BHI } \\
200 \mu \mathrm{L} \text { inóc. }\end{array}$ & $\begin{array}{l}50 \mu \mathrm{L} \text { BHI } \\
200 \mu \mathrm{L} \text { inóc. }\end{array}$ & $\begin{array}{l}50 \mu \mathrm{L} \text { BHI } \\
200 \mu \mathrm{L} \text { inóc. }\end{array}$ & $\begin{array}{l}50 \mu \mathrm{L} \text { BHI } \\
200 \mu \mathrm{L} \text { inóc. }\end{array}$ & $\begin{array}{l}50 \mu \mathrm{L} \text { BHI } \\
200 \mu \mathrm{L} \text { inóc. }\end{array}$ & $\begin{array}{l}50 \mu \mathrm{L} \text { BHI } \\
200 \mu \mathrm{L} \text { inóc. }\end{array}$ & $\begin{array}{l}50 \mu \mathrm{L} \text { BHI } \\
200 \mu \mathrm{L} \text { inóc. }\end{array}$ & $\begin{array}{l}50 \mu \mathrm{L} \text { BHI } \\
200 \mu \mathrm{L} \text { inóc. }\end{array}$ \\
\hline $\mathrm{C}$ & $\begin{array}{l}50 \mu \mathrm{L} \text { S2 } \\
200 \mu \mathrm{L} \text { inóc. }\end{array}$ & $\begin{array}{l}50 \mu \mathrm{L} \text { S1 } \\
200 \mu \mathrm{L} \text { inóc. }\end{array}$ & $\begin{array}{l}20 \mu \mathrm{L} \text { BHI } \\
30 \mu \mathrm{L} \mathrm{S} 2 \\
200 \mu \mathrm{L} \text { inóc. }\end{array}$ & $\begin{array}{l}50 \mu \mathrm{L} \text { BHI } \\
50 \mu \mathrm{L} \mathrm{S1} \\
200 \mu \mathrm{L} \text { inóc. }\end{array}$ & $\begin{array}{l}50 \mu \mathrm{L} \text { BHI } \\
200 \mu \mathrm{L} \text { inóc. }\end{array}$ & $\begin{array}{l}50 \mu \mathrm{L} \text { BHI } \\
200 \mu \mathrm{L} \text { inóc. }\end{array}$ & $\begin{array}{l}50 \mu \mathrm{L} \text { BHI } \\
200 \mu \mathrm{L} \text { inóc. }\end{array}$ & $\begin{array}{l}50 \mu \mathrm{L} \text { BHI } \\
200 \mu \mathrm{L} \text { inóc. }\end{array}$ & $\begin{array}{l}50 \mu \mathrm{L} \text { BHI } \\
200 \mu \mathrm{L} \text { inóc. }\end{array}$ & $\begin{array}{l}50 \mu \mathrm{L} \text { BHI } \\
200 \mu \mathrm{L} \text { inóc. }\end{array}$ & $\begin{array}{l}50 \mu \mathrm{L} \text { BHI } \\
200 \mu \mathrm{L} \text { inóc. }\end{array}$ & $\begin{array}{l}50 \mu \mathrm{L} \text { BHI } \\
200 \mu \mathrm{L} \text { inóc. }\end{array}$ \\
\hline D & & & & & & & & & & & & \\
\hline $\mathbf{E}$ & & & & & & & & & & & & \\
\hline $\mathbf{F}$ & & & & & & & & & & & & \\
\hline G & $\begin{array}{l}50 \mu \mathrm{L} \text { BHI } \\
200 \mu \mathrm{L} \text { inóc. }\end{array}$ & $\begin{array}{l}50 \mu \mathrm{L} \text { BHI } \\
200 \mu \mathrm{L} \text { inóc. }\end{array}$ & $\begin{array}{l}50 \mu \mathrm{L} \text { BHI } \\
200 \mu \mathrm{L} \text { inóc. }\end{array}$ & $\begin{array}{l}50 \mu \mathrm{L} \text { BHI } \\
200 \mu \mathrm{L} \text { inóc. }\end{array}$ & $\begin{array}{l}50 \mu \mathrm{L} \text { BHI } \\
200 \mu \mathrm{L} \text { inóc. }\end{array}$ & $\begin{array}{l}50 \mu \mathrm{L} \text { BHI } \\
200 \mu \mathrm{L} \text { inóc. }\end{array}$ & $\begin{array}{l}50 \mu \mathrm{L} \text { BHI } \\
200 \mu \mathrm{L} \text { inóc. }\end{array}$ & $\begin{array}{l}50 \mu \mathrm{L} \text { BHI } \\
200 \mu \mathrm{L} \text { inóc. }\end{array}$ & $\begin{array}{l}50 \mu \mathrm{L} \text { BHI } \\
200 \mu \mathrm{L} \text { inóc. }\end{array}$ & $\begin{array}{l}50 \mu \mathrm{L} \text { BHI } \\
200 \mu \mathrm{L} \text { inóc. }\end{array}$ & $\begin{array}{l}50 \mu \mathrm{L} \text { BHI } \\
200 \mu \mathrm{L} \text { inóc. }\end{array}$ & $\begin{array}{l}50 \mu \mathrm{L} \text { BHI } \\
200 \mu \mathrm{L} \text { inóc. }\end{array}$ \\
\hline $\mathbf{H}$ & $250 \mu \mathrm{L}$ BHI & $250 \mu \mathrm{L}$ BHI & $250 \mu \mathrm{L}$ BHI & $250 \mu \mathrm{L}$ BHI & $250 \mu \mathrm{LBHI}$ & $250 \mu \mathrm{L}$ BHI & $250 \mu \mathrm{LBHI}$ & $250 \mu \mathrm{L}$ BHI & $250 \mu \mathrm{L}$ BHI & $250 \mu \mathrm{L}$ BHI & $250 \mu \mathrm{L}$ BHI & $250 \mu \mathrm{L}$ BHI \\
\hline
\end{tabular}


Quadro 3 - Protocolo de preparo da microplaca de cultivo para a determinação da concentração inibitória mínima do óleo-resina de copaíba.

\begin{tabular}{|c|c|c|c|c|c|c|c|c|c|c|c|c|}
\hline & 1 & 2 & 3 & 4 & 5 & 6 & 7 & 8 & 9 & 10 & 11 & 12 \\
\hline [] & $3,0 \mathrm{mg} / \mathrm{mL}$ & $2,8 \mathrm{mg} / \mathrm{mL}$ & $2,6 \mathrm{mg} / \mathrm{mL}$ & $2,4 \mathrm{mg} / \mathrm{mL}$ & $2,2 \mathrm{mg} / \mathrm{mL}$ & $2,0 \mathrm{mg} / \mathrm{mL}$ & $1,8 \mathrm{mg} / \mathrm{mL}$ & $1,6 \mathrm{mg} / \mathrm{mL}$ & $1,4 \mathrm{mg} / \mathrm{mL}$ & $1,2 \mathrm{mg} / \mathrm{mL}$ & $1,1 \mathrm{mg} / \mathrm{mL}$ & $1,0 \mathrm{mg} / \mathrm{mL}$ \\
\hline $\mathbf{A}$ & $\begin{array}{c}50 \mu \mathrm{L} \text { S3 } \\
200 \mu \mathrm{L} \text { inóc. }\end{array}$ & $\begin{array}{c}47 \mu \mathrm{L} \text { S3 } \\
3,0 \mu \mathrm{L} \text { BHI } \\
200 \mu \mathrm{L} \text { inóc. }\end{array}$ & $\begin{array}{c}44 \mu \mathrm{L} \text { S3 } \\
6,0 \mu \mathrm{L} \text { BHI } \\
200 \mu \mathrm{L} \text { inóc }\end{array}$ & $\begin{array}{c}40 \mu \mathrm{L} \text { S3 } \\
10 \mu \mathrm{L} \text { BHI } \\
200 \mu \mathrm{L} \text { inóc }\end{array}$ & $\begin{array}{c}37 \mu \mathrm{L} \text { S3 } \\
13 \mu \mathrm{L} \text { BHI } \\
200 \mu \mathrm{L} \text { inóc }\end{array}$ & $\begin{array}{c}34 \mu \mathrm{L} \text { S3 } \\
16 \mu \mathrm{L} \text { BHI } \\
200 \mu \mathrm{L} \text { inóc }\end{array}$ & $\begin{array}{c}30 \mu \mathrm{L} \text { S3 } \\
20 \mu \mathrm{L} \text { BHI } \\
200 \mu \mathrm{L} \text { inóc }\end{array}$ & $\begin{array}{c}27 \mu \mathrm{L} \mathrm{S3} \\
23 \mu \mathrm{L} \text { BHI } \\
200 \mu \mathrm{L} \text { inóc }\end{array}$ & $\begin{array}{c}24 \mu \mathrm{L} \text { S3 } \\
26 \mu \mathrm{L} \text { BHI } \\
200 \mu \mathrm{L} \text { inóc }\end{array}$ & $\begin{array}{c}20 \mu \mathrm{L} \text { S3 } \\
30 \mu \mathrm{L} \text { BHI } \\
200 \mu \mathrm{L} \text { inóc }\end{array}$ & $\begin{array}{c}18 \mu \mathrm{L} \text { S3 } \\
32 \mu \mathrm{L} \text { BHI } \\
200 \mu \mathrm{L} \text { inóc }\end{array}$ & $\begin{array}{c}17 \mu \mathrm{L} \mathrm{S3} \\
33 \mu \mathrm{L} \text { BHI } \\
200 \mu \mathrm{L} \text { inóc }\end{array}$ \\
\hline B & $\begin{array}{c}50 \mu \mathrm{L} \text { S3 } \\
200 \mu \mathrm{L} \text { inóc. }\end{array}$ & $\begin{array}{c}47 \mu \mathrm{L} \text { S3 } \\
3,0 \mu \mathrm{L} \text { BHI } \\
200 \mu \mathrm{L} \text { inóc. }\end{array}$ & $\begin{array}{c}44 \mu \mathrm{L} \text { S3 } \\
6,0 \mu \mathrm{L} \text { BHI } \\
200 \mu \mathrm{L} \text { inóc }\end{array}$ & $\begin{array}{c}40 \mu \mathrm{L} \mathrm{S3} \\
10 \mu \mathrm{L} \text { BHI } \\
200 \mu \mathrm{L} \text { inóc }\end{array}$ & $\begin{array}{c}37 \mu \mathrm{L} \text { S3 } \\
13 \mu \mathrm{L} \text { BHI } \\
200 \mu \mathrm{L} \text { inóc }\end{array}$ & $\begin{array}{c}34 \mu \mathrm{L} \text { S3 } \\
16 \mu \mathrm{L} \text { BHI } \\
200 \mu \mathrm{L} \text { inóc }\end{array}$ & $\begin{array}{c}30 \mu \mathrm{L} \text { S3 } \\
20 \mu \mathrm{L} \text { BHI } \\
200 \mu \mathrm{L} \text { inóc }\end{array}$ & $\begin{array}{c}27 \mu \mathrm{L} \text { S3 } \\
23 \mu \mathrm{L} \text { BHI } \\
200 \mu \mathrm{L} \text { inóc }\end{array}$ & $\begin{array}{c}24 \mu \mathrm{L} \text { S3 } \\
26 \mu \mathrm{L} \text { BHI } \\
200 \mu \mathrm{L} \text { inóc }\end{array}$ & $\begin{array}{c}20 \mu \mathrm{L} \mathrm{S3} \\
30 \mu \mathrm{L} \text { BHI } \\
200 \mu \mathrm{L} \text { inóc }\end{array}$ & $\begin{array}{c}18 \mu \mathrm{L} \mathrm{S} 3 \\
32 \mu \mathrm{L} \text { BHI } \\
200 \mu \mathrm{L} \text { inóc }\end{array}$ & $\begin{array}{c}17 \mu \mathrm{L} \text { S3 } \\
33 \mu \mathrm{L} \text { BHI } \\
200 \mu \mathrm{L} \text { inóc }\end{array}$ \\
\hline C & $\begin{array}{c}50 \mu \mathrm{L} \text { S3 } \\
200 \mu \mathrm{L} \text { inóc. }\end{array}$ & $\begin{array}{c}47 \mu \mathrm{L} \mathrm{S3} \\
3,0 \mu \mathrm{L} \text { BHI } \\
200 \mu \mathrm{L} \text { inóc. }\end{array}$ & $\begin{array}{c}44 \mu \mathrm{L} \text { S3 } \\
6,0 \mu \mathrm{L} \text { BHI } \\
200 \mu \mathrm{L} \text { inóc }\end{array}$ & $\begin{array}{c}40 \mu \mathrm{L} \mathrm{S3} \\
10 \mu \mathrm{L} \text { BHI } \\
200 \mu \mathrm{L} \text { inóc }\end{array}$ & $\begin{array}{c}37 \mu \mathrm{L} \mathrm{S3} \\
13 \mu \mathrm{L} \text { BHI } \\
200 \mu \mathrm{L} \text { inóc }\end{array}$ & $\begin{array}{c}34 \mu \mathrm{L} \text { S3 } \\
16 \mu \mathrm{L} \text { BHI } \\
200 \mu \mathrm{L} \text { inóc }\end{array}$ & $\begin{array}{c}30 \mu \mathrm{L} \mathrm{S} 3 \\
20 \mu \mathrm{L} \text { BHI } \\
200 \mu \mathrm{L} \text { inóc }\end{array}$ & $\begin{array}{c}27 \mu \mathrm{L} \text { S3 } \\
23 \mu \mathrm{L} \text { BHI } \\
200 \mu \mathrm{L} \text { inóc }\end{array}$ & $\begin{array}{c}24 \mu \mathrm{L} \text { S3 } \\
26 \mu \mathrm{L} \text { BHI } \\
200 \mu \mathrm{L} \text { inóc }\end{array}$ & $\begin{array}{c}20 \mu \mathrm{L} \mathrm{S} 3 \\
30 \mu \mathrm{L} \text { BHI } \\
200 \mu \mathrm{L} \text { inóc }\end{array}$ & $\begin{array}{c}18 \mu \mathrm{L} \mathrm{S3} \\
32 \mu \mathrm{L} \text { BHI } \\
200 \mu \mathrm{L} \text { inóc }\end{array}$ & $\begin{array}{c}17 \mu \mathrm{L} \text { S3 } \\
33 \mu \mathrm{L} \text { BHI } \\
200 \mu \mathrm{L} \text { inóc }\end{array}$ \\
\hline D & & & & & & & & & & & & \\
\hline $\mathbf{E}$ & & & & & & & & & & & & \\
\hline $\mathbf{F}$ & & & & & & & & & & & & \\
\hline G & $\begin{array}{c}50 \mu \mathrm{L} \text { BHI } \\
200 \mu \mathrm{L} \text { inóc. }\end{array}$ & $\begin{array}{c}50 \mu \mathrm{L} \text { BHI } \\
200 \mu \mathrm{L} \text { inóc. }\end{array}$ & $\begin{array}{c}50 \mu \mathrm{L} \text { BHI } \\
200 \mu \mathrm{L} \text { inóc. }\end{array}$ & $\begin{array}{c}50 \mu \mathrm{L} \text { BHI } \\
200 \mu \mathrm{L} \text { inóc. }\end{array}$ & $\begin{array}{c}50 \mu \mathrm{L} \text { BHI } \\
200 \mu \mathrm{L} \text { inóc. }\end{array}$ & $\begin{array}{c}50 \mu \mathrm{L} \text { BHI } \\
200 \mu \mathrm{L} \text { inóc. }\end{array}$ & $\begin{array}{c}50 \mu \mathrm{L} \text { BHI } \\
200 \mu \mathrm{L} \text { inóc. }\end{array}$ & $\begin{array}{c}50 \mu \mathrm{L} \text { BHI } \\
200 \mu \mathrm{L} \text { inóc. }\end{array}$ & $\begin{array}{c}50 \mu \mathrm{L} \text { BHI } \\
200 \mu \mathrm{L} \text { inóc. }\end{array}$ & $\begin{array}{c}50 \mu \mathrm{L} \text { BHI } \\
200 \mu \mathrm{L} \text { inóc. }\end{array}$ & $\begin{array}{c}50 \mu \mathrm{L} \text { BHI } \\
200 \mu \mathrm{L} \text { inóc. }\end{array}$ & $\begin{array}{c}50 \mu \mathrm{L} \text { BHI } \\
200 \mu \mathrm{L} \text { inóc. }\end{array}$ \\
\hline $\mathbf{H}$ & $250 \mu \mathrm{L} \mathrm{BHI}$ & $250 \mu \mathrm{L} \mathrm{BHI}$ & $250 \mu \mathrm{L}$ BHI & $250 \mu \mathrm{L}$ BHI & $250 \mu \mathrm{L}$ BHI & $250 \mu \mathrm{L} \mathrm{BHI}$ & $250 \mu \mathrm{L} \mathrm{BHI}$ & $250 \mu \mathrm{L}$ BHI & $250 \mu \mathrm{L}$ BHI & $250 \mu \mathrm{L}$ BHI & $250 \mu \mathrm{L} \mathrm{BHI}$ & $250 \mu \mathrm{L}$ BHI \\
\hline
\end{tabular}


De acordo com o Quadro 2, primeiro pipetou-se o volume meio BHI contendo 2,0\% DMSO em todas as cavidades correspondentes: fileiras A-C colunas 3-12; fileiras $\mathrm{G}$ e H, colunas 1-12. Em seguida, adicionou-se as soluções do óleo-resina de copaíba e efetuou-se as diluições nas fileiras A-C colunas 4-12, de maneira a obter concentrações de $1,0 \mathrm{mg} / \mathrm{mL}$ a $1,6 \mu \mathrm{g} / \mathrm{mL}$ de óleo-resina de copaíba. Finalmente, pipetou-se o inóculo padronizado $\left(10^{5} \mathrm{UFC} / \mathrm{mL}\right)$. As fileiras A-C correspondem à avaliação, em triplicata, da concentração inibitória mínima do óleo-resina. A fileira $G$, contendo apenas o inóculo e o meio BHI com 2,0\% de DMSO corresponde ao controle positivo e a fileira $\mathrm{H}$, é o controle de esterilidade do meio de cultura. O volume final em cada cavidade foi de $250 \mu \mathrm{L}$ (VALDEVITE, 2007).

Em virtude da diferença de sensibilidade entre os microrganismos, outro protocolo também foi realizado, como apresentado no Quadro 3. Primeiramente pipetou-se o volume de meio BHI contendo 2,0\% de DMSO em todas as cavidades correspondentes: fileiras A-C, colunas 2-12 e fileiras $\mathrm{G}$ e $\mathrm{H}$, colunas 112. Em seguida, adicionou-se as soluções estoque do óleo-resina de copaíba nas fileiras A-C colunas 2-12, de maneira a obter concentrações de 3,0 mg/mL a 1,0 $\mathrm{mg} / \mathrm{mL}$ de óleo-resina de copaíba. Finalmente, pipetou-se o inóculo padronizado na densidade de $10^{5} \mathrm{UFC} / \mathrm{mL}$. O volume final em cada cavidade foi de $250 \mu \mathrm{L}$.

Após o preparo das placas, as mesmas foram envoltas em papel alumínio, incubadas à temperatura de $37^{\circ} \mathrm{C}$, sob agitação de $40 \mathrm{rpm}$, durante 15 horas (Incubadora Shaker Marconi- Mod. MA420). Após este período, adicionouse a cada cavidade $50 \mu \mathrm{L}$ de uma solução de azul de nitrotetrazólio (Nitrotetrazolium blue chloride - Sigma) 0,125\% (p/v), para se obter uma concentração final de 0,025\% em cada cavidade.

Após a adição do indicador, as microplacas foram incubadas novamente a $37^{\circ} \mathrm{C}$, sob agitação de $40 \mathrm{rpm}$, durante 30 minutos e adicionais 90 minutos em temperatura ambiente, totalizando o tempo de 2 horas de incubação. 0 crescimento bacteriano foi indicado pela coloração azul do derivado de formazan produzido pela metabolização bacteriana do sal de tetrazólio. A menor concentração do óleo-resina onde não mais observou-se crescimento bacteriano visível (ausência de coloração) foi estabelecida como a concentração inibitória mínima. 


\subsubsection{Determinação da Concentração Bactericida Mínima (CBM)}

A concentração bactericida mínima foi estabelecida como a menor concentração do óleo-resina de copaíba que impossibilitou o crescimento bacteriano sobre o ágar. Para tal finalidade, uma alíquota de $250 \mu \mathrm{L}$ a partir de cada cavidade da microplaca onde não observou-se crescimento bacteriano foi semeada em placa de Petri de vidro estéril contendo o meio de cultura BHI ágar. Para a determinação da CBM para o microrganismo S. pyogenes, as placas foram incubadas a $37^{\circ} \mathrm{C}$ durante 24 horas em atmosfera de microaerofilia (chama de vela). Para os demais microrganismos avaliados, a incubação foi realizada em aerobiose.

Todo o material empregado nos ensaios microbiológicos, incluindo vidrarias, frascos de centrífuga, pipetas e ponteiras, foi devidamente esterilizado e todos os procedimentos foram executados assepticamente.

\subsubsection{ESTUDO 6: Avaliação da atividade antimicrobiana in vivo do óleo- resina de copaíba em úlceras cutâneas infectadas em ratos}

A atividade antimicrobiana in vivo do óleo-resina de copaíba foi avaliada frente a cepas padrão ATCC: S. aureus (ATCC 6538) e S. pyogenes (ATCC 19615), adquiridas da empresa American Type of Culture Collection (Manassas, Virgínia - EUA).

\subsubsection{Meios de cultura}

Os seguintes meios de cultura foram preparados, de acordo com as instruções dos fabricantes: BHI (Becton, Dickinson and Company - EUA), na concentração de 3,7\%; Tioglicolato sem dextrose ou indicador (Becton, Dickinson and Company - EUA), 2,4\%; Tioglicolato sem dextrose ou indicador 2,4\% com $10 \%$ de glicerina (Fisher Chemical - EUA); Tryptic Soy Agar (TSA - MP 
Biomedicals North America - EUA) 4,0\%; TSA 4,0\% com 5,0\% de sangue desfibrinado de carneiro; Tryptic Soy Broth (TSB - MP Biomedicals North America - EUA) 3,0\%; TSB 3,0\% com 10\% de glicerina e Mueller-Hinton (Oxoid - EUA) 2,1\% com 1,5\% de Ágar-ágar (Fisher BioReagents - EUA). Imediatamente após a pesagem dos reagentes e homogeneização em água destilada, todos os meios de cultura foram autoclavados à temperatura de $121^{\circ} \mathrm{C}$ e pressão de vapor a 1,0 $\mathrm{Kgf} / \mathrm{cm}^{2}$, durante 20 minutos (Consolidated ${ }^{\circledR}$ Autoclave. Midwest Biomedical \& Scientific Services, Inc., Madison, Wisconsin - EUA).

\subsubsection{Cultivo dos microrganismos}

Os microrganismos, obtidos na forma liofilizada, foram primeiramente reidratados em meio de cultura meio BHI (S. aureus) e Tioglicolato sem dextrose ou indicador (S. pyogenes).

A partir do meio BHI contendo o microrganismo $S$. aureus, alíquotas foram assepticamente inoculadas em diferentes meios de cultura: BHI, TSB, MHa (ágar inclinado em tubos), TSA (placa de Petri), TSA (ágar inclinado em tubos) e TSA suplementado com $5 \%$ de sangue desfibrinado de carneiro. Os meios foram incubados a $37^{\circ} \mathrm{C}$ durante 24 horas, em aerobiose (Mechanical convection 30M precision incubator. EUA).

A partir do meio Tioglicolato sem dextrose ou indicador contendo o microrganismo S. pyogenes, alíquotas foram assepticamente inoculadas em diferentes meios de cultura: BHI, Tioglicolato sem dextrose ou indicador e TSA suplementado com $5 \%$ de sangue desfibrinado de carneiro. Os meios foram incubados a $37^{\circ} \mathrm{C}$ durante 24 horas, em atmosfera de $5 \%$ de $\mathrm{CO}_{2}$ (Thermo Scientific Napco Series 8000 DH, CO 2 Incubator, Thermo Scientific. EUA).

Após observação da viabilidade e caracterização das colônias, os meios de cultura líquidos foram centrifugados a $1500 \mathrm{rpm}$ durante 15 minutos e os pellets foram ressuspensos nos meios de congelamento TSB com $10 \%$ de glicerina (S. aureus) e Tioglicolato sem dextrose ou indicador com $10 \%$ de glicerina (S. pyogenes). As alíquotas foram armazenadas à temperatura de $-20^{\circ} \mathrm{C}$ até o momento do uso. 


\subsubsection{Indução experimental de infecção}

Partindo-se das alíquotas congeladas, o microrganismo $S$. aureus foi cultivado em meio de cultura $\mathrm{BHI}$ a $37^{\circ} \mathrm{C}$, em aerobiose, durante 24 horas. $\mathrm{O}$ microrganismo S. pyogenes foi cultivado em meio de cultura Tioglicolato sem dextrose ou indicador a $37^{\circ} \mathrm{C}$, em atmosfera de $5 \%$ de $\mathrm{CO}_{2}$, durante 24 horas.

As culturas foram centrifugadas a $7740 \mathrm{rpm}(11500 \times \mathrm{g})$, a $4^{\circ} \mathrm{C}$, durante 2 minutos (Sorvall RC-5C Centrifuge. EUA), o sobrenadante foi descartado e o pellet foi ressuspenso em $1,0 \mathrm{~mL}$ de solução fisiológica $(0,9 \%)$ estéril em diversos volumes. Após homogeneização em vortex, o número de colônias foi determinado por espectrofotometria (Shimadzu Spectrophotometer. UV-2501PC; UV-VIS Recording Spectrophotometer, Kyoto, Japão). As absorbâncias a $625 \mathrm{~nm}$ foram comparadas com o padrão de turbidez 0,5 da escala de McFarland (Becton, Dickinson and Company - EUA), o qual tem absorbância que varia entre 0,08 a 0,10 (a $625 \mathrm{~nm}$ ) e representa a contagem de aproximadamente $10^{8}$ UFC/mL (BERG et al., 2006).

Várias diluições foram feitas à partir dos pellets até que se estabelecesse a concentração com a mesma absobância do padrão de turbidez utilizado. Foram preparadas soluções contendo aproximadamente $10^{8} \mathrm{UFC} / \mathrm{mL}$, as quais foram utlizadas para a inoculação nas úlceras em um período não superior a 2 horas.

Após a indução das úlceras, conforme descrito no item 2.3.1, o volume de $20,0 \mu \mathrm{L}$ de suspensão bacteriana foi inoculado em cada úlcera utilizando uma pipeta estéril. O procedimento foi realizado assepticamente dentro de uma capela de fluxo laminar. Imediatamente após a inoculação dos microrganismos, as úlceras foram cobertas com filme de poliuretano (Tegaderm ${ }^{\circledR}$, 3M HealthCare, Saint Paul, Minnesota - EUA) utilizado como curativo primário para assegurar um ambiente fechado durante as primeiras 24 horas. Sob o curativo primário foi utilizado gaze estéril como curativo secundário e uma bandagem auto-adesiva, mantida com esparadrapo, como curativo terciário. A partir do $2^{\circ}$ dia, utilizou-se gaze estéril como curativo primário e a bandagem auto-adesiva, mantida com esparadrapo, como curativo secundário. 


\subsubsection{Grupos de tratamento}

Foram utilizados 57 ratos, os quais foram divididos em 2 grupos principais: grupo com úlceras infectadas com $S$. aureus (27 ratos) e grupo com úlceras infectadas com S. pyogenes (27 ratos). Cada grupo foi subdivido em 3 grupos conforme os tratamentos: solução fisiológica, creme base e creme a 10\% de óleo-resina de copaíba, sendo 3 animais utilizados em cada dia de avaliação/tratamento, nos dias 2, 7 e 14 após o procedimento cirúrgico (Figura 12).

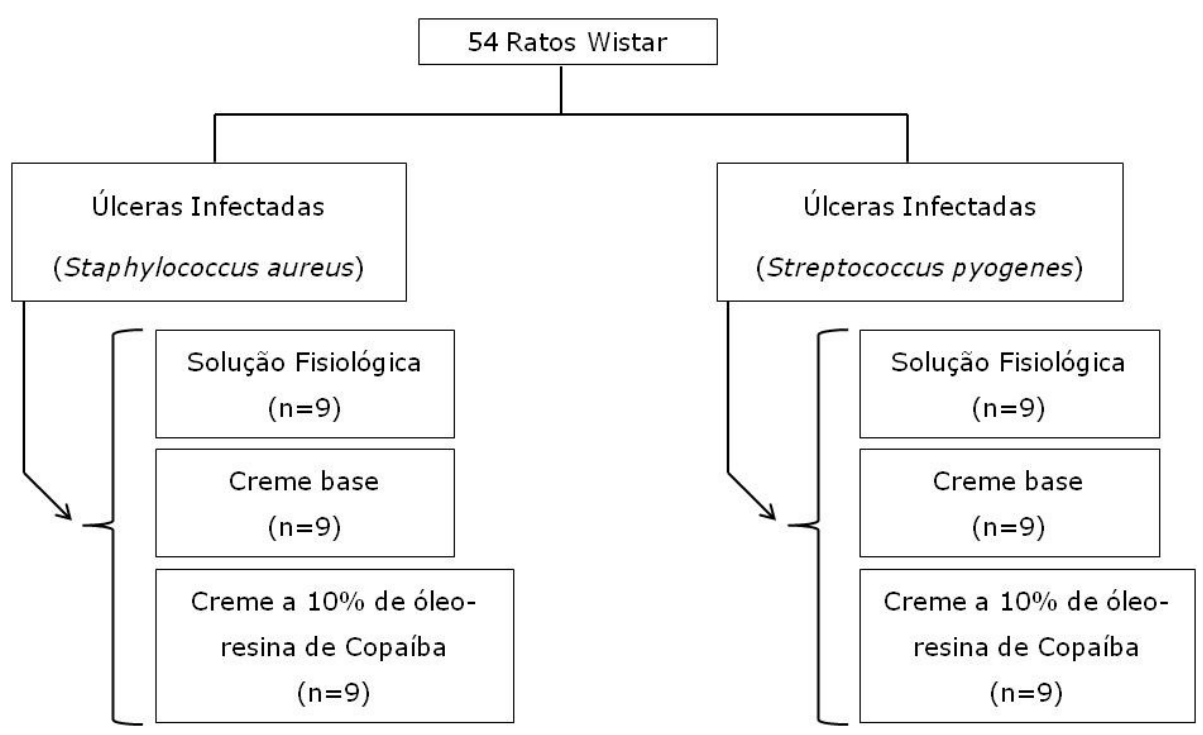

Figura 12 - Fluxograma dos grupos de tratamento para a avaliação da atividade antimicrobiana in vivo do óleo-resina de copaíba (Estudo 6), assim como para a avaliação do seu potencial cicatrizante (Estudo 7).

\subsubsection{Avaliação da atividade antimicrobiana}

Os perfis microbiológicos das úlceras (exsudato e tecido profundo) foram determinados. Primeiramente avaliou-se a presença dos microrganismos no leito das úlceras, 24 horas após a inoculação, através da coleta do exsudato com swab. Posteriormente, durante todo o período de tratamento, realizou-se o seguimento do perfil microbiológico para a avaliação dos tratamentos aplicados 
às úlceras infectadas, a partir de swabs e biópsias, nos dias 2, 7 e 14 após o procedimento cirúrgico (Figura 13).

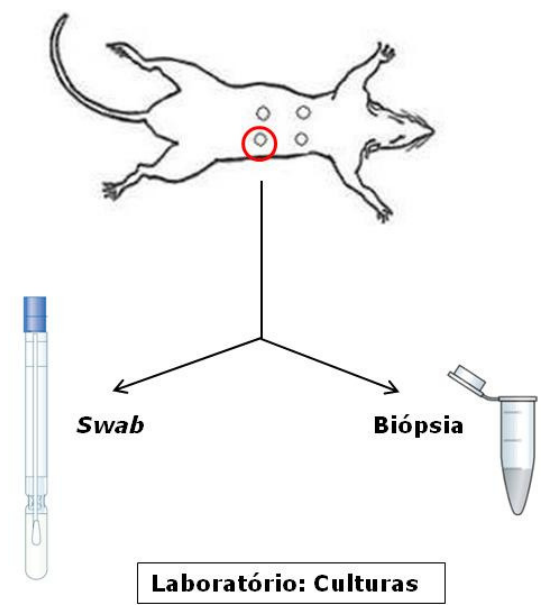

Figura 13 - Representação esquemática da obtenção de amostra para a cultura microbiológica a partir das úlceras.

\subsection{Avaliação inicial do perfil microbiológico das úlceras}

Vinte e quatro horas após a inoculação das suspensões bacterianas as úlceras foram avaliadas quanto à presença de sinais clínicos de infecção local como edema, eritema, purulência e excesso de exsudato.

Colheu-se o exsudato do centro de cada úlcera cirúrgica através da rotação de swab de rayon estéril (Fisherfinest bacteriology culture collection and transport system, Fisher HealthCare, Ontario - Canadá) por 3 vezes no sentido horário. Imediatamente após a coleta, cada swab foi colocado de volta ao meio de transporte (Amies) que o acompanhava (SULLIVAN et al., 2004). O meio Amies é um gel de cor clara a levemente opalescente usado para o transporte de espécimes microbiológicos por manter a viabilidade dos microrganismos, porém sem permitir a sua multiplicação. É composto por cloreto de sódio, cloreto de potássio, cloreto de cálcio, cloreto de magnésio, fosfato monopotássico, fosfato dissódico, tioglicolato de sódio e ágar, com pH final de 7,3.

Quando as úlceras encontravam-se secas, como no 70 e $14^{\circ}$ dias, os swabs foram ligeiramente umedecidos em solução fisiológica estéril imediatamente antes da coleta (UPPAL et al., 2007). 
As amostras foram levadas ao laboratório dentro de um período máximo de 2 horas para o processamento e realização das culturas. Cada swab foi colocado em um tubo cônico contendo $1,0 \mathrm{~mL}$ de solução fisiológica estéril e homogeneizado (vortex) durante 1 minuto. A seguir, foram realizadas quatro diluições decimais: $1: 10 ; 1: 100 ; 1: 1000 ; 1: 10.000$ com solução fisiológica estéril. A partir de cada diluição, assim como a partir da solução inicial do swab em solução fisiológica, o volume de $100 \mu \mathrm{L}$ foi inoculado em placas de Petri contendo o meio TSA suplementado com $5 \%$ de sangue desfibrinado de carneiro $\left(\right.$ Remel $^{\circledR}$, Lenexa, Kansas - EUA). As placas foram incubadas a $37^{\circ} \mathrm{C}$ em aerobiose (para amostras obtidas de úlceras infectadas com $S$. aureus) e em atmosfera de $5 \%$ de $\mathrm{CO}_{2}$ (para amostras obtidas de úlceras infectadas com S. pyogenes), durante 24 horas.

A densidade bacteriana, ou contagem de unidades formadoras de colônias (UFCs) por mililitro (UFC/mL) foi determinada pela multiplicação do número de colônias hemolíticas contadas em uma placa ( $n$ ) pela diluição (D) onde a contagem foi possível, pelo volume plaqueado (o número 10 foi usado para $100 \mu \mathrm{L}$ ) segundo a fórmula:

\section{$\mathrm{UFC} / \mathrm{mL}=\mathbf{n} \times \mathrm{D} \times \mathbf{1 0}$}

\subsection{Seguimento do perfil microbiológico das úlceras}

Nos dias 2, 7 e 14 após indução cirúrgica das úlceras e inoculação das bactérias, procedeu-se a eutanásia dos ratos por overdose de anestésico (isoflurano) e imediatamente colheu-se swabs para a avaliação antimicrobiana como anteriormente descrito (item 5.2.6.5.1)

Biópsias, das mesmas úlceras onde se colheu swabs, foram obtidas utilizando-se punch cirúrgico para biópsia de pele $(8,0 \mathrm{~mm})$. Cada biópsia foi colhida em um microtubo cônico pré-pesado contendo $1,0 \mathrm{~mL}$ de solução fisiológica estéril. Os tubos foram mantidos em banho de gelo durante o procedimento de coleta e transporte. As amostras foram levadas para o 
laboratório dentro de um período máximo de 2 horas entre coleta e processamento, para a realização das culturas.

Os microtubos contendo as biópsias foram pesados novamente para determinar o peso do tecido biopsiado (em gramas). Cada biópsia foi assepticamente seccionada com bisturi estéril e homogeneizada (vortex) durante 2 minutos para a remoção dos microrganismos aderentes ao tecido.

A seguir, foram realizadas quatro diluições decimais: 1:10; 1:100; $1: 1000 ; 1: 10.000$ com solução fisiológica estéril. A partir de cada diluição, e a partir do tubo sem diluição, o volume de $100 \mu \mathrm{L}$ foi inoculado em placas de Petri contendo o meio TSA com $5 \%$ de sangue desfibrinado de carneiro. As placas foram incubadas a $37^{\circ} \mathrm{C}$ em aerobiose (para amostras obtidas de úlceras infectadas com S. aureus) e em atmosfera de $5 \%$ de $\mathrm{CO}_{2}$ (para amostras obtidas de úlceras infectadas com S. pyogenes), durante 24 horas.

A densidade bacteriana, ou contagem de unidades formadoras de colônias por grama de tecido (UFC/g) foi determinada pela multiplicação do número de colônias hemolíticas contadas em uma placa ( $n$ ) pela diluição (D) onde a contagem foi possível, pelo volume de solução fisiológica necessário para homogeneização da amostra, pelo volume plaqueado (o número 10 foi usado para $100 \mu \mathrm{L}$ ) dividido pelo peso da amostra em gramas (BUCHANAN et al., 1986; SULLIVAN et al., 2004), segundo a fórmula:

\section{UFC $/ \mathrm{g}$ tecido $=\mathbf{n} \times \mathrm{D} \times \mathrm{V} \times 10$ peso da amostra (g)}

Durante todo o seguimento, ou seja, durante 14 dias, a presença de sinais clínicos de infecção nas úlceras foi cuidadosamente observada. Todo o material empregado nos ensaios microbiológicos, incluindo vidrarias, frascos de centrífuga, pipetas e ponteiras, foi devidamente esterilizado e todos os procedimentos foram executados assepticamente em capela com fluxo laminar. 


\subsubsection{ESTUDO 7: Avaliação do potencial cicatrizante do óleo-resina de copaíba em úlceras cutâneas infectadas em ratos}

Após a indução cirúrgica das úlceras em ratos, conforme descrito no item 5.2.3.1, e indução experimental de infecção (item 5.2.6.3), realizou-se a avaliação do potencial cicatrizante do óleo-resina de copaíba de acordo com os itens 5.2.3.3 a 5.2.3.6, ou seja: seguimento clínico-experimental, avaliação histopatológica e avaliações bioquímicas (dosagem de hidroxiprolina e de metaloproteinases). Os grupos de tratamento estão descritos no item 5.2.6.4.

\subsubsection{Análise Estatística}

Os gráficos foram feitos utilizando-se o software GraphPad Prism 3.0. Os valores de absorbância, contagem de células por minuto e porcentagem relativa (estudos de citotoxicidade), ICUs, conteúdo de hidroxiprolina, atividade enzimática das metaloproteinases e contagem bacteriana (UFC/mL e UFC/g de tecido) foram expressos como a média \pm desvio-padrão. Os resultados foram analisados, utilizando o mesmo software, pelo teste ANOVA, seguido do pósteste de Bonferroni para comparações múltiplas. Valores de $p<0,05$ mostraram evidências estatísticas de que houve diferença entre os dados em questão sob intervalo de confiança de $95 \%$. 
"É melhor tentar, ainda em vão, que sentar-se fazendo nada até o final. $\mathcal{E}$ u prefiro na chuva caminhar, que em dias tristes me esconder. Prefiro ser feliz, embora louco, que em conformidade viver". 


\section{RESULTADOS}

\subsection{ESTUDO 1: Avaliação da citotoxicidade do óleo-resina de copaíba em cultura de fibroblastos NIH-3T3}

\subsubsection{Avaliação da viabilidade celular}

A viabilidade celular dos fibroblastos foi aferida pelo método colorimétrico MTT, que é baseado na capacidade das células viáveis de reduzirem o sal de tetrazólio em cristais de formazan. A coloração púrpura foi aferida por espectrofotometria e a absorbância do grupo controle foi relacionada a $100 \%$ de células viáveis.

A viabilidade diminuiu com o aumento da concentração do óleo-resina de copaíba. Considerando-se as concentrações avaliadas do óleo-resina nas culturas (1 a $1000 \mu \mathrm{g} / \mathrm{mL}$ ), até a concentração de $100 \mu \mathrm{g} / \mathrm{mL}$ em torno de 90 a $100 \%$ das células permaneceram viáveis. Houve redução da viabilidade celular nas concentrações de 500 e $1000 \mu \mathrm{g} / \mathrm{mL}$ de óleo-resina, com 70\% e 73\% de células viáveis, respectivamente. Estes resultados estão expressos como porcentagem relativa de cada tratamento (soluções de óleo-resina) comparado ao grupo controle (meio de cultura), de acordo com a Figura 14. As culturas celulares que receberam 500 e $1000 \mu \mathrm{g} / \mathrm{mL}$ apresentaram diferença estatisticamente significante comparadas ao controle (meio de cultura), com valores de $p<0,001$. 


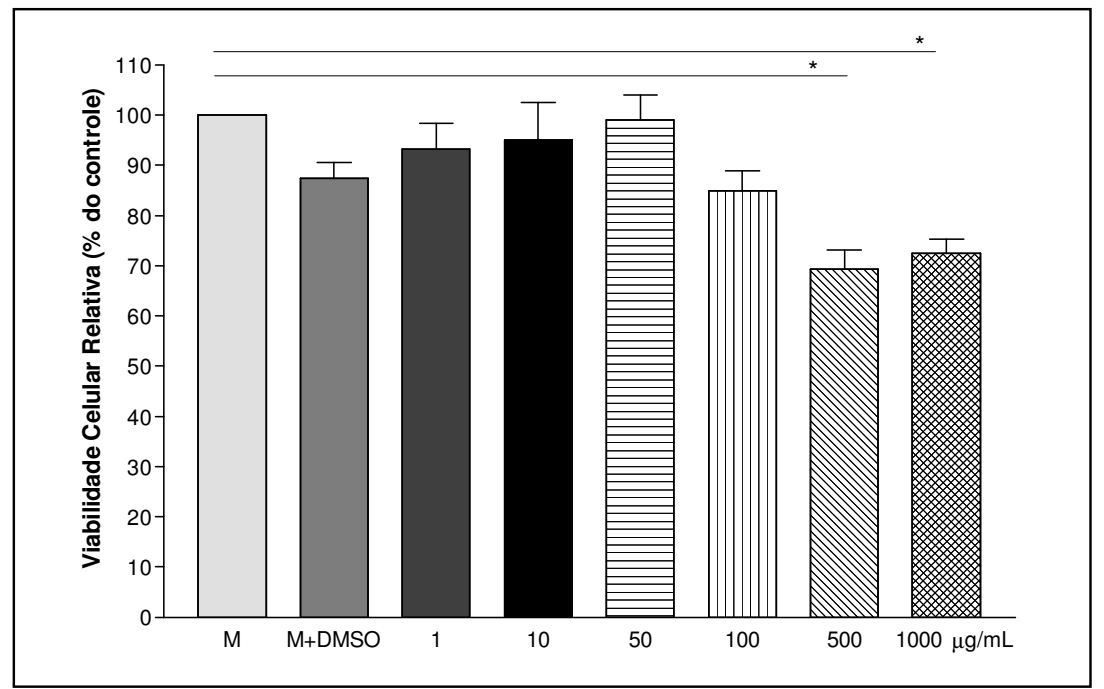

Figura 14 - Percentual de células viáveis em relação à cultura controle, distribuído conforme os tratamentos das culturas: Meio de cultura (M); Meio de cultura contendo DMSO (M+DMSO); Concentrações do óleo-resina de copaíba 1,0; 10; 50; 100; 500 e $1000 \mu \mathrm{g} / \mathrm{mL}$. Os resultados representam as médias \pm desvio-padrão em triplicata. *Diferença estatisticamente significante $(p<0,001)$ em relação ao controle $(M)$.

Quando os valores de absorbância das culturas em função da concentração de óleo-resina aplicada foram plotados (Figura 15) observou-se a diminuição da densidade óptica para as células tratadas com altas concentrações de óleo-resina de copaíba. Houve diferença estatisticamente significante para as concentrações de 500 e $1000 \mu \mathrm{g} / \mathrm{mL}$ comparadas a todos os outros grupos, com valores de $p<0,001$.

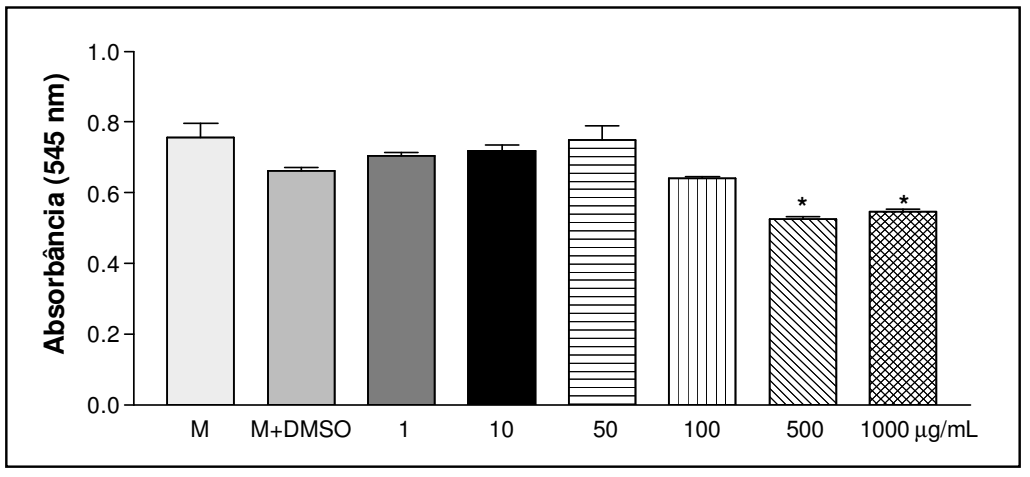

Figura 15 - Resultado do teste MTT conforme absorbância das culturas, distribuído conforme os tratamentos das culturas: Meio de cultura (M); Meio de cultura contendo DMSO (M+DMSO); Concentrações do óleo-resina de copaíba 1,0; 10; 50; 100; 500 e $1000 \mu \mathrm{g} / \mathrm{mL}$. Os resultados representam as médias \pm desvio-padrão em triplicata. *Diferença estatisticamente significante $(p<0,001)$ em relação a todos os outros grupos. 


\subsubsection{Avaliação da proliferação celular}

A proliferação celular, aferida pela incorporação da $\mathrm{H}^{3}$-Timidina, também apresentou um perfil dose-dependente, observando-se declínio na proliferação celular nas concentrações de 500 e $1000 \mu \mathrm{g} / \mathrm{mL}$, uma vez que em torno de 40\% das células encontravam-se mitoticamente competentes. Os resultados estão expressos como porcentagem relativa de cada tratamento (soluções de óleoresina) comparado ao grupo controle (meio de cultura) na Figura 16. As culturas que receberam 500 e $1000 \mu \mathrm{g} / \mathrm{mL}$ apresentaram diferença estatisticamente significante comparadas ao controle (meio de cultura), com valores de $p<0,01$.

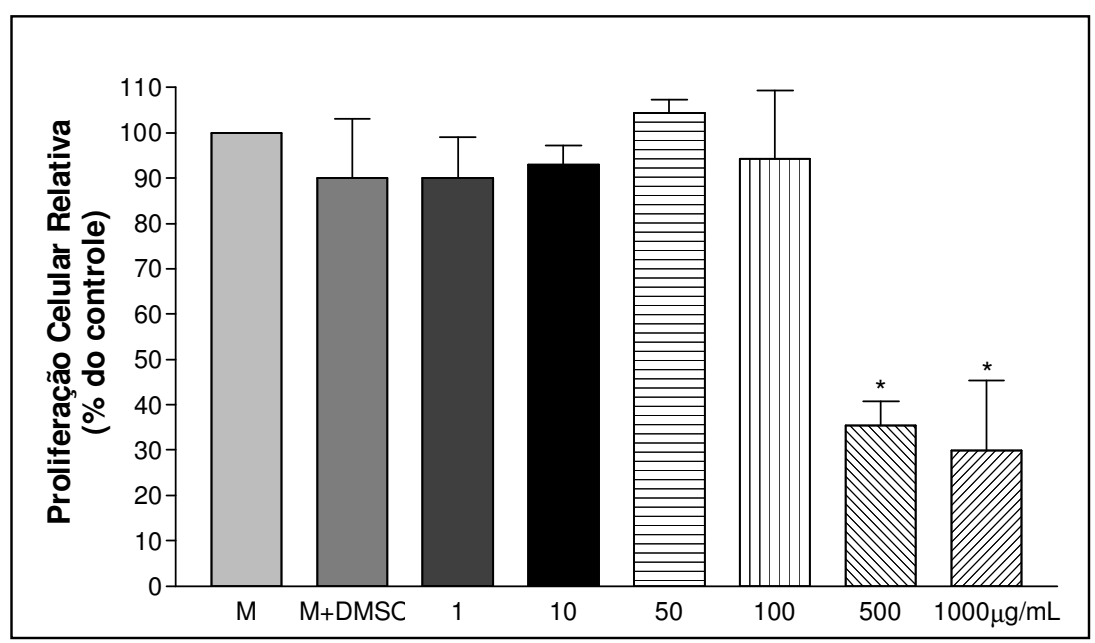

Figura 16 - Percentual de proliferação celular pela incorporação do $\mathrm{H}^{3}$-Timidina relativa a cultura controle conforme os tratamentos das culturas: Meio de cultura (M); Meio de cultura contendo DMSO (M+DMSO); Concentrações do óleo-resina de copaíba 1,0; 10; 50; 100; 500 e $1000 \mu \mathrm{L} / \mathrm{mL}$. Os resultados representam as médias \pm desvio-padrão em triplicata. *Diferença estatisticamente significante $(p<0,01)$ em relação ao controle $(M)$.

Quando os valores da contagem de células por minuto foram plotados em função da concentração de óleo-resina aplicada (Figura 17) observou-se a diminuição da proliferação celular das culturas tratadas com altas concentrações de óleo-resina. Houve diferença estatisticamente significante para as concentrações de 500 e $1000 \mu \mathrm{g} / \mathrm{mL}$ comparadas a todos os outros grupos, com valores de $p<0,01$ comparados com meio de cultura e 50, e valores de $p<0,05$ 
quando comparado com meio+DMSO, 1, 10 e $100 \mu \mathrm{g} / \mathrm{mL}$ (esta concentração comparada a $1000 \mu \mathrm{g} / \mathrm{mL}$ teve valor de $\mathrm{p}<0,01$ ).

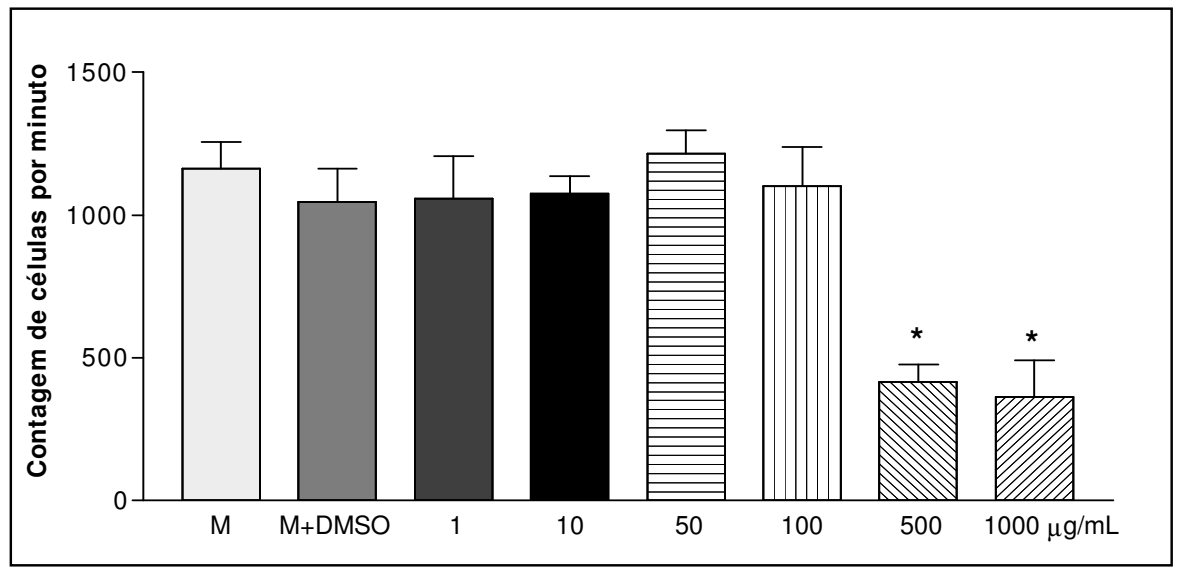

Figura 17 - Contagem de células incorporadas $\left(H^{3}\right.$-Timidina) por minuto distribuídas conforme os tratamentos das culturas: Meio de cultura (M); Meio de cultura contendo DMSO (M+DMSO); Concentrações do óleo-resina de copaíba 1,0; 10; 50; 100; 500 e $1000 \mu \mathrm{g} / \mathrm{mL}$. Os resultados representam as médias \pm desvio-padrão em triplicata. *Diferença estatisticamente significante em relação a todos os outros grupos.

\subsection{ESTUDO 2: Avaliação do potencial cicatrizante do óleo-resina de copaíba em úlceras cutâneas no modelo de orelha de coelho}

\subsubsection{Seguimento clínico-experimental}

Imagens fotográficas de todas as úlceras foram capturadas para a documentação do seguimento clínico-experimental, assim como para a avaliação computacional das áreas ulceradas para o cálculo dos valores dos ICUs.

A Figura 18 representa o seguimento clínico-fotográfico das úlceras na superfície dorsal da orelha de coelhos. As fotos apresentadas na figura são representativas de uma orelha de cada animal, ou seja, de cada tratamento e estão dispostas de acordo com o tempo de seguimento nos dias 0, 2, 7, 14 e 21. Foram utilizados 2 coelhos por tratamento.

No $2^{\circ}$ dia após o procedimento cirúrgico, as úlceras tratadas com solução fisiológica (Figura 18b), creme base (Figura 18g) e cremes a 10 (Figura 18I) e $25 \%$ (Figura 18q) de óleo-resina de copaíba, apresentavam fundos cobertos 
por fibrina condizentes clinicamente com a fase inflamatória do processo normal de cicatrização. Nos animais tratados com óleo-resina puro (Figura 18v), as úlceras apresentaram-se maiores evidenciando o potencial inflamatório do óleo puro e consequente agressão tecidual.

No 70 dia, as úlceras tratadas com solução fisiológica (Figura 18c), creme base (Figura 18h) e cremes a 10 (Figura 18m) e 25\% (Figura 18r) de óleo-resina apresentavam crostas, enquanto nas úlceras tratadas com óleoresina puro (Figura 18w) notou-se aumento de inflamação e toda a superfície dorsal das orelhas encontrava-se coberta por crostas e escamação.

No $14^{\circ}$ dia, a maioria das úlceras tratadas com solução fisiológica (Figura 18d), creme base (Figura 18i) e creme a $10 \%$ de óleo-resina (Figura 18n) estavam reepitelizadas, sendo que aquelas tratadas com creme a $10 \%$ de óleo-resina apresentavam melhor resultado clínico. Nas úlceras tratadas com creme a $25 \%$ de óleo-resina (Figura 18s) e óleo-resina puro (Figura 18x), ainda observa-se a presença de crostas e lesões não-reepitelizadas. Ao final do seguimento (21 dias) todas as úlceras estavam reepitelizadas, exceto algumas lesões tratadas com o óleo-resina puro (Figura $\mathbf{1 8 e}, \mathbf{j}, \mathbf{0}, \mathbf{t}, \mathbf{y}$ ). 


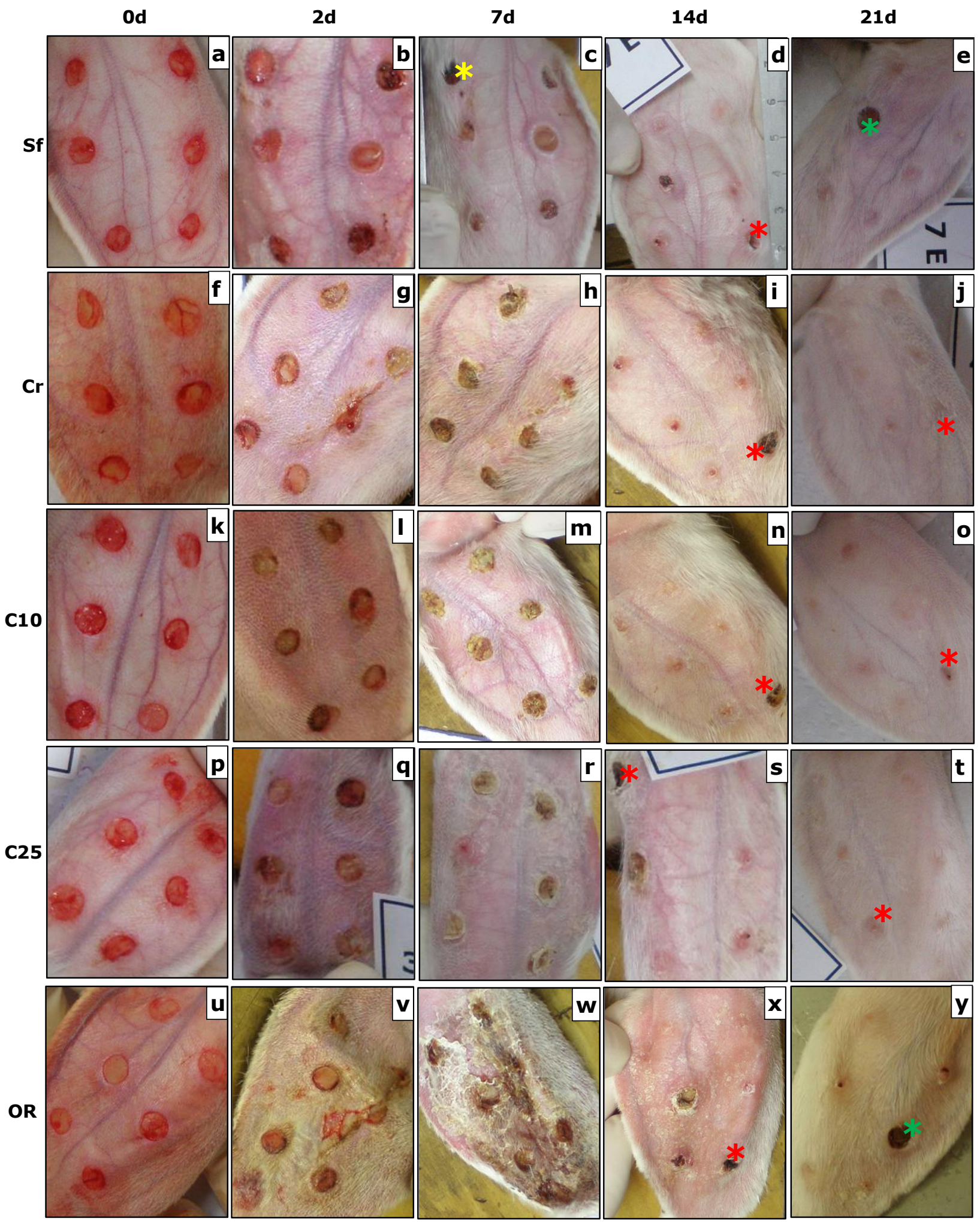

Figura 18 - Seguimento clínico das úlceras nos dias 0, 2, 7, 14 e 21 respectivamente, conforme os tratamentos: Solução fisiológica (Sf) (a-e); Creme base (Cr) (f-j); Cremes a 10\% (C10) (k-o) e a $25 \%$ de óleo-resina (C25) (p-t); Óleo-resina puro (OR) (u-y). * representa os locais onde biópsias foram colhidas durante o seguimento e as cores indicam o dia em que as mesmas foram colhidas: amarelo (2 dias), vermelho (7 dias) e verde (14 dias). 


\subsection{2 Índice de Cicatrização das Úlceras (ICU)}

Após a análise clínico-experimental das úlceras, as áreas foram avaliadas para a determinação dos índices de cicatrização. No 20 dia após o procedimento cirúrgico, os valores de ICU para os grupos tratados com cremes a $10 \%$ e $25 \%$ de óleo-resina de copaíba foram superiores quando comparados aos outros grupos, com diferença estatisticamente significante quando comparados aos grupos tratados com creme base $(p<0,05 ; p<0,01$, respectivamente) $(n=24)$ (Figura 19). Algumas úlceras tiveram suas áreas aumentadas, visto que apresentaram valores de ICU inferiores a zero.

No 70 dia, não houve diferença nos ICUs $(n=22)$ entre os tratamentos aplicados. No $14^{\circ} \mathrm{dia}$, a maioria das úlceras estava reepitelizada, principalmente do grupo tratado com $10 \%$ de copaíba, diferente dos outros grupos $(n=20)$. No $21^{\circ}$ dia, as úlceras estavam reepitelizadas, com valores de ICU iguais a 1 , exceto algumas tratadas com óleo-resina puro (valores de ICU entre 0,94 e 0,96) $(n=18)$.

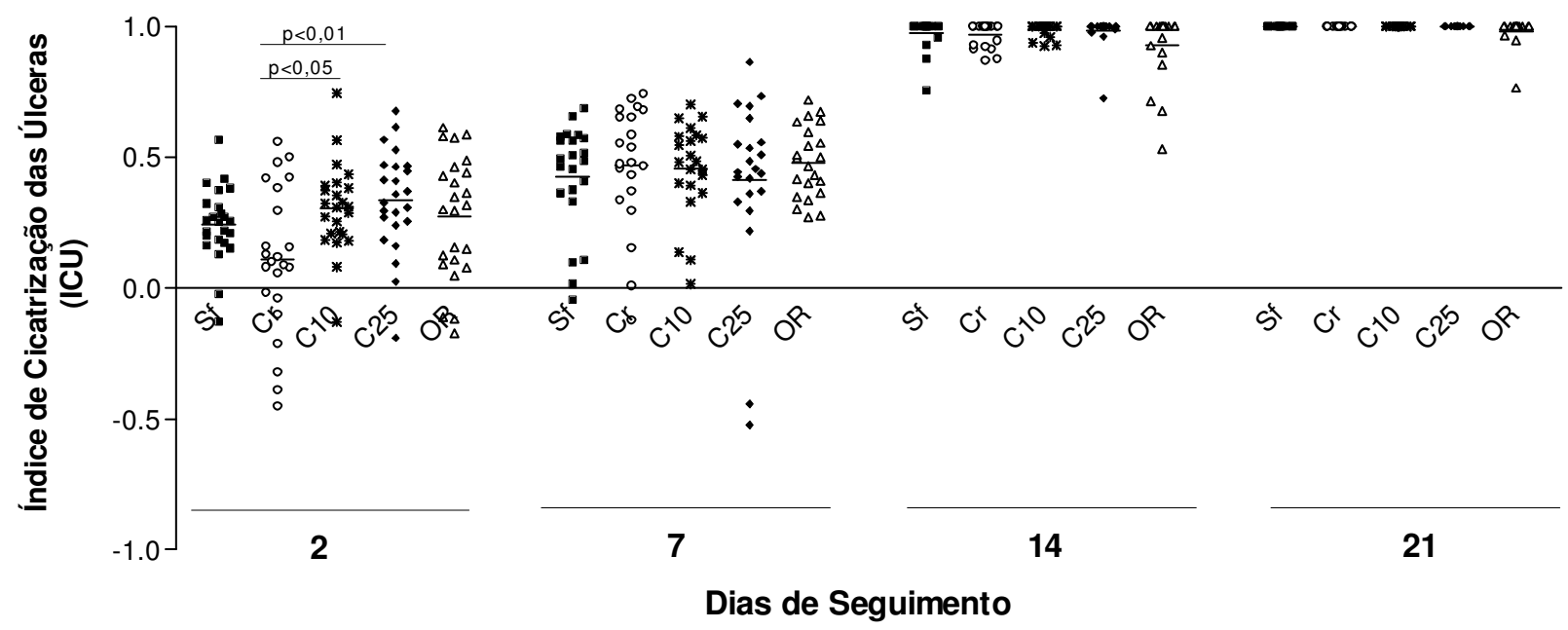

Figura 19 - Evolução dos índices de cicatrização das úlceras (ICUs) nos tempos de avaliação de 2, 7, 14 e 21 dias, conforme os tratamentos: Solução fisiológica (Sf), Creme base (Cr), Cremes a $10 \%$ (C10) e a 25\% (C25) de óleo-resina de copaíba, e óleo-resina puro (OR). Os valores representam a média \pm desvio-padrão. Diferenças estatisticamente significantes $C 10 \times C r(p<0,05)$ e $\mathrm{C} 25 \mathrm{xCr}(\mathrm{p}<0,01)$, no dia 2. 


\subsubsection{Avaliação histopatológica}

A análise qualitativa da celularidade e do infiltrado inflamatório foi realizada pela coloração das lâminas por hematoxilina-eosina (Figura 20). No 20 dia após o procedimento cirúrgico, observou-se infiltrado inflamatório mais intenso (predominantemente neutrofílico) nas lâminas correspondentes às úlceras tratadas com o óleo-resina puro, quando comparadas aos demais tratamentos (Figura 20a, e, i, $\mathbf{m}, \mathbf{q}$ ). No entanto, as úlceras tratadas com creme base, creme a $10 \%$ e $25 \%$ de óleo-resina também apresentaram infiltrado inflamatório importante.

No 70 dia, as lâminas correspondentes às úlceras tratadas com solução fisiológica (Figura 20b), creme base (Figura 20f) e cremes a 10\% (Figura 20j) e a 25\% (Figura 20n) de óleo-resina apresentaram evidência de atividade fibroblástica enquanto no grupo tratado com óleo-resina puro (Figura 20r) ainda observa-se a presença de inflamação.

No $14^{\circ}$ dia, as lâminas correspondentes às úlceras tratadas com solução fisiológica (Figura 20c), creme a 25\% de óleo-resina (Figura 200) e óleoresina puro (Figura 20s) mostraram mais fibroblastos quando comparadas aos grupos creme base (Figura $\mathbf{2 0 g}$ ) e creme a $10 \%$ de óleo-resina (Figura 20k).

No $21^{\circ}$ dia, as lâminas correspondentes às úlceras tratadas com óleoresina puro (Figura 20t) apresentaram número maior de fibroblastos quando comparadas aos outro grupos de tratamento (Figura $\mathbf{2 0 d}, \mathbf{h}, \mathbf{I}, \mathbf{p}, \mathbf{t}$ ), entretanto os mesmos se apresentaram mais desorganizados.

A análise qualitativa da colagênese também foi realizada. Utilizou-se coloração com o tricrômio de Gomori, visto que as fibras de colágeno coram-se de azul/verde, o que facilita a sua visualização (Figura 21). Em todos os grupos avaliados, a intensidade de cor aumentou gradualmente durante o seguimento, indicando, qualitativamente, aumento da colagênese. Entretanto, quando se comparou as lâminas correspondentes às úlceras tratadas com o óleo-resina puro, no $21^{\circ}$ dia, notou-se menor intensidade de coloração (azul/verde), indicativa de menor quantidade de colágeno nestas úlceras. 


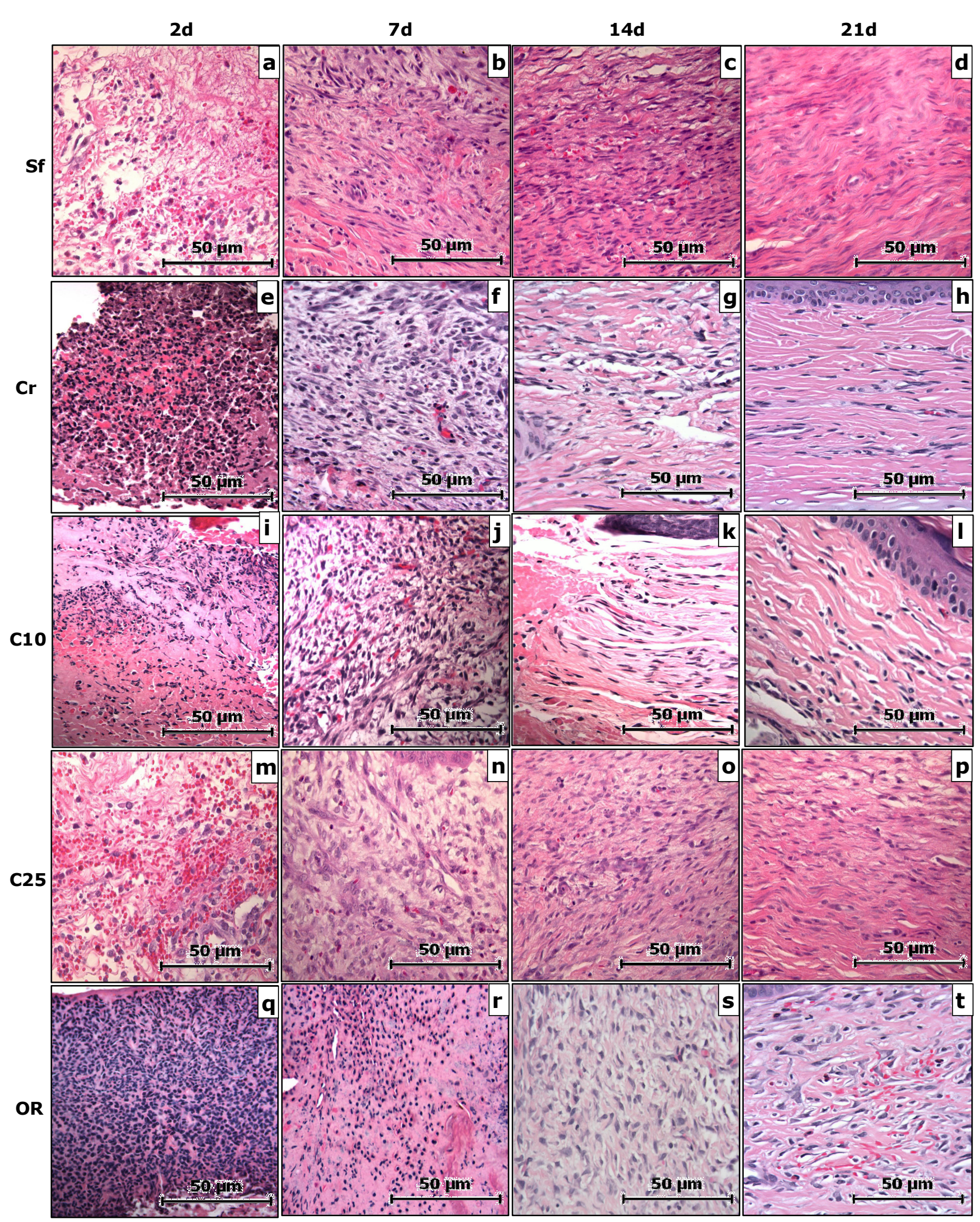

Figura 20- Avaliação histopatológica das úlceras nos dias 2, 7, 14 e 21 respectivamente, conforme os tratamentos: Solução fisiológica (Sf) (a-d); Creme base (Cr) (e-h); Cremes a 10\% (C10) (i-I) e a 25\% de óleo-resina de copaíba (C25) (m-p); Óleo-resina puro (OR) (q-t). Coloração hematoxilina-eosina. Aumento de 400x. 


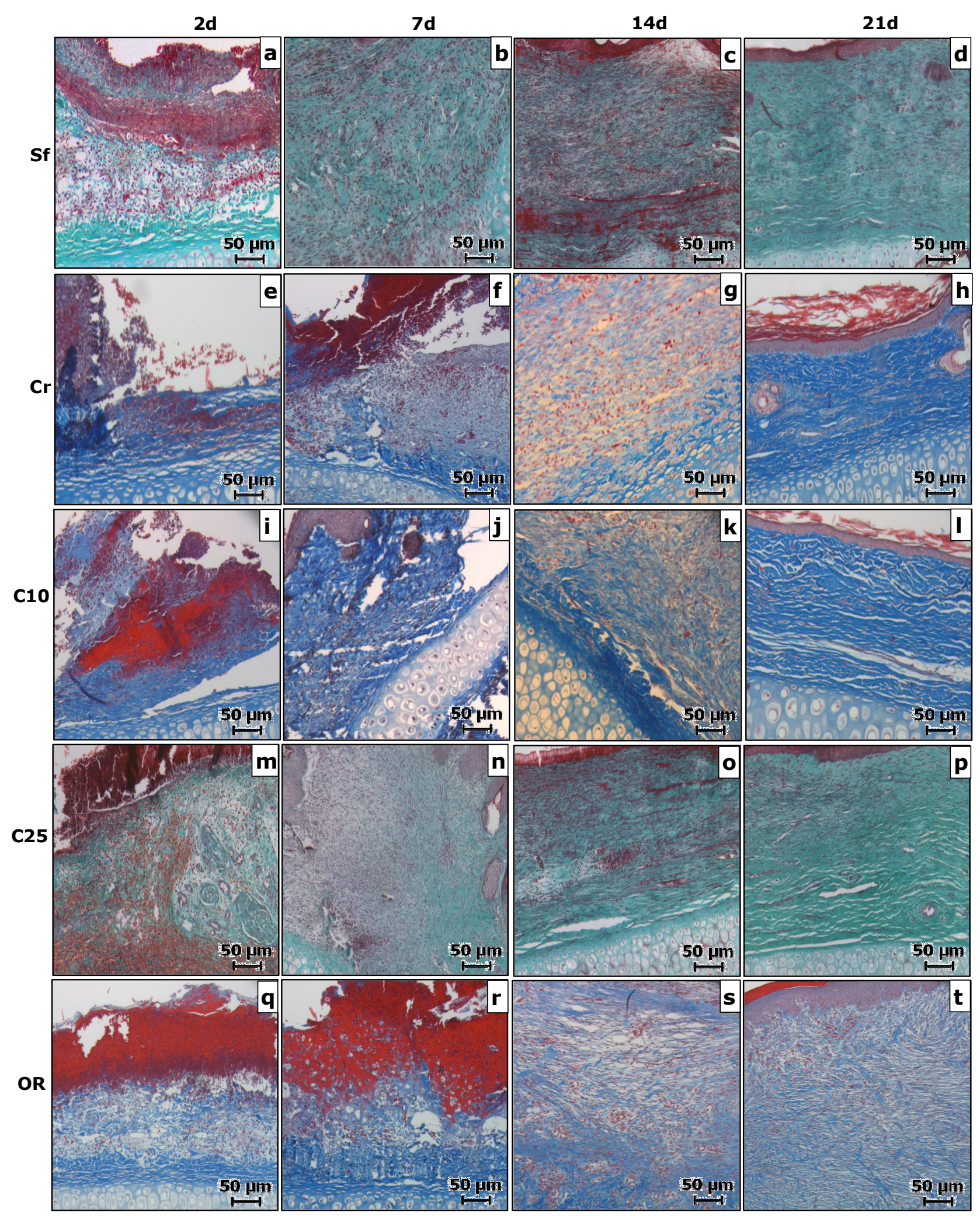

Figura 21- Avaliação histopatológica das úlceras nos dias 2, 7, 14 e 21 respectivamente, conforme os tratamentos: Solução fisiológica (Sf) (a-d); Creme base (Cr) (e-h); Cremes a 10\% (C10) (i-I) e a 25\% de óleo-resina de copaíba (C25) (m-p); Óleo-resina puro (OR) (q-t). Coloração tricrômio de Gomori. Aumento de 100x. 


\subsection{ESTUDO 3: Avaliação do potencial cicatrizante do óleo-resina de copaíba em úlceras cutâneas em ratos}

\subsubsection{Seguimento clínico-experimental}

A Figura 22 representa o seguimento clínico-fotográfico das úlceras, com fotos representativas das úlceras de um animal por tratamento e por dia de seguimento. As imagens estão dispostas de acordo com o tempo de seguimento nos tempos de 0, 2, 7 e 14 dias. O dia zero representa as úlceras na região dorsal de rato imediatamente após o procedimento cirúrgico, ou seja, sem aplicação de qualquer tratamento.

No $2^{\circ}$ dia após o procedimento cirúrgico, as úlceras tratadas com creme base (Figura 22f) e creme a 10\% de óleo-resina (Figura 22j) apresentavam-se mais úmidas e algumas úlceras tiveram aumento de área, comparadas às úlceras tratadas com solução fisiológica (Figura 22b).

No 70 dia, as úlceras tratadas com solução fisiológica (Figura 22c) apresentavam crostas firmemente aderidas. As úlceras tratadas com creme base (Figura 22g) ainda exibiam certo grau de inflamação e as úlceras tratadas com creme a $10 \%$ de óleo-resina apresentavam bom perfil de cicatrização, com diminuição importante das áreas ulceradas (Figura 22k).

No $14^{\circ}$ dia, as úlceras tratadas com solução fisiológica (Figura 22d) e creme a $10 \%$ de óleo-resina (Figura 22I) estavam reepitelizadas, embora a qualidade do tecido cicatricial nas úlceras tratadas com copaíba parecia estar superior ao tecido do grupo solução fisiológica. Nas úlceras tratadas com creme base (Figura 22h), a maioria das úlceras estava reepitelizada, porém algumas ainda mantinham crostas firmemente aderidas. 


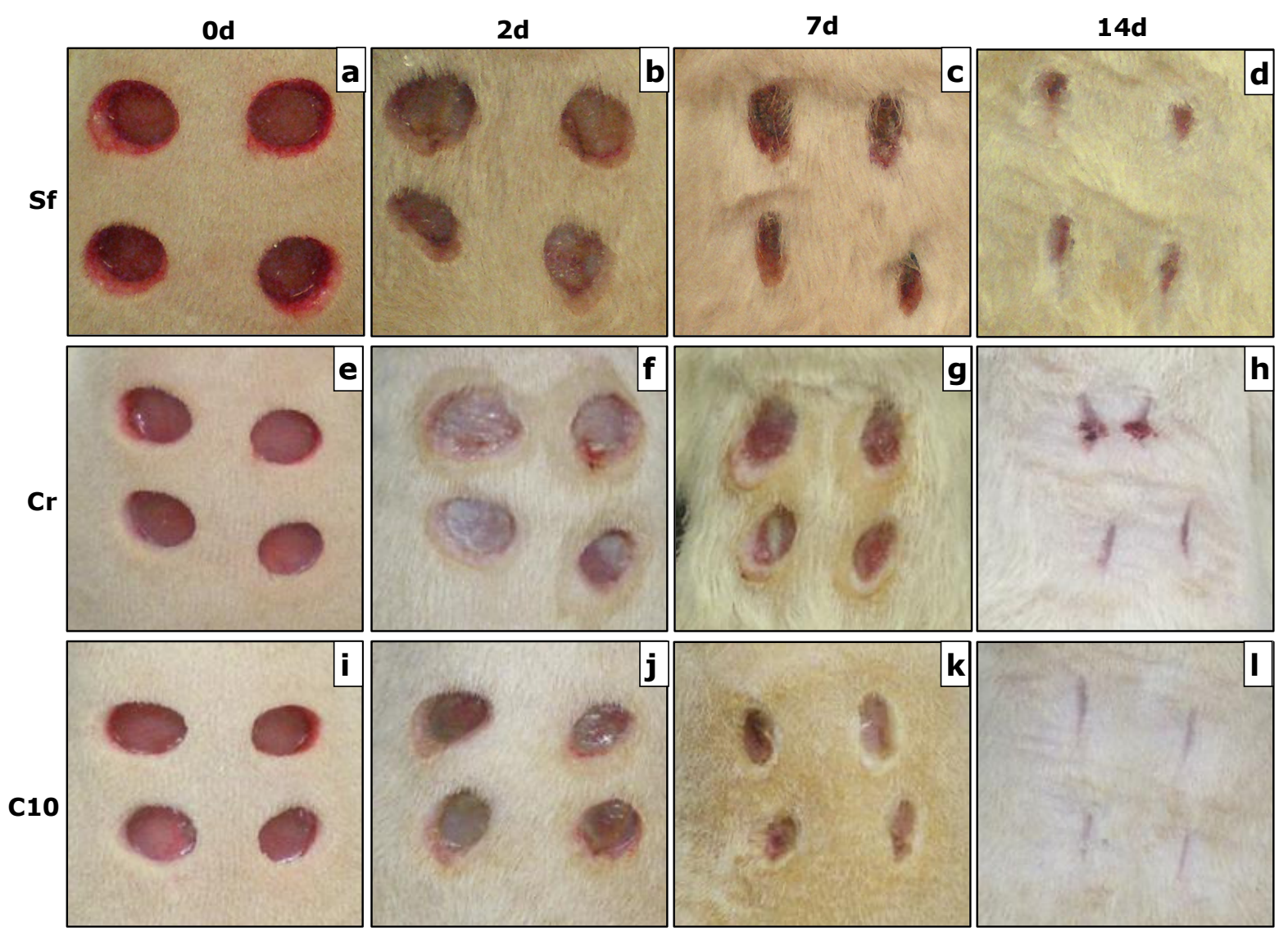

Figura 22 - Seguimento clínico das úlceras nos dias 0, 2, 7 e 14 respectivamente, conforme os tratamentos: Solução fisiológica (Sf) (a-d); Creme base (Cr) (e-h); Creme a $10 \%$ de óleo-resina (C10) (i-I)

\subsection{2 Índice de Cicatrização das Úlceras (ICU)}

No $2^{\circ}$ dia após o procedimento cirúrgico, os valores de ICU para os grupos tratados com cremes base e a $10 \%$ de óleo-resina foram inferiores quando comparados ao grupo tratado com solução fisiológica, com diferença estatisticamente significante para ambos os grupos $(p<0,05)$ (Figura 23).

No 70 dia, os valores de ICU para as úlceras tratadas com solução fisiológica e creme a $10 \%$ de óleo-resina foram superiores ao grupo tratado com creme base, com diferença estatisticamente significante entre o grupo solução fisiológica e creme base $(p<0,05)$. Os ICUs para as úlceras tratadas com creme a $10 \%$ de óleo-resina demonstraram uma tendência ligeiramente superior aos demais grupos, porém sem diferença estatística. 
No 140 dia, a maioria das úlceras estava reepitelizada, com exceção de algumas úlceras tratadas com creme base (valores de ICU entre 0,94 e 0,99).

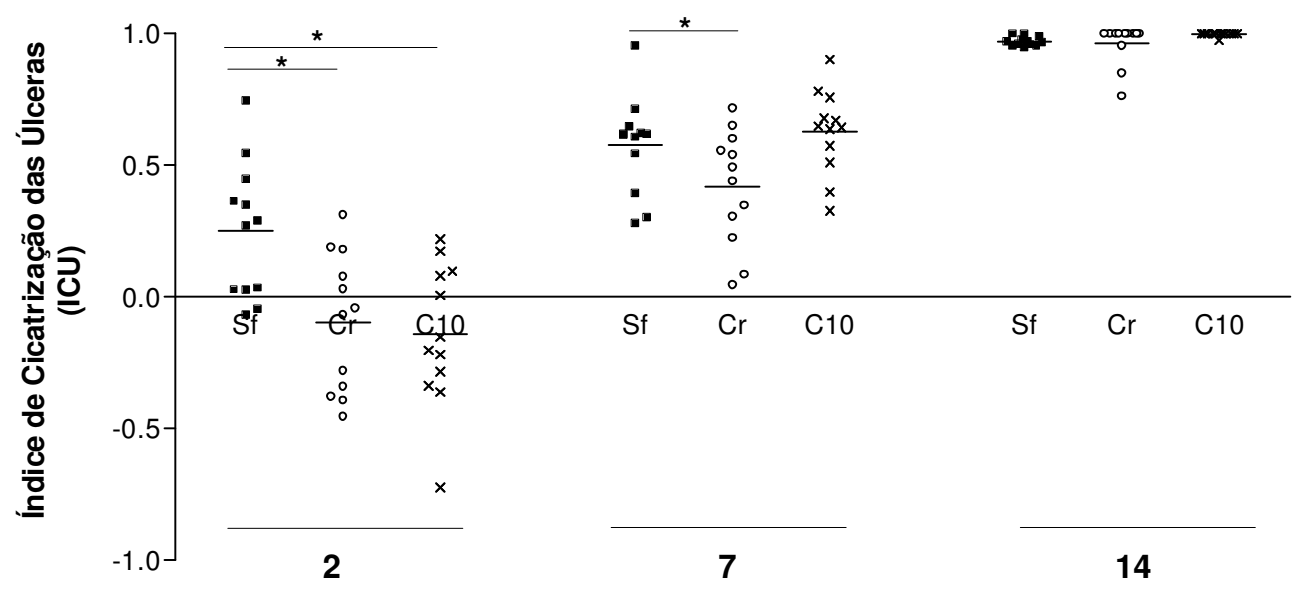

Dias de Seguimento

Figura 23 - Evolução dos índices de cicatrização das úlceras (ICUs) nos tempos de avaliação de 2, 7 e 14 dias, conforme os tratamentos: Solução fisiológica (Sf), Creme base $(\mathrm{Cr})$, Creme a $10 \%$ de óleo-resina de copaíba (C10). Os valores representam a média \pm desvio-padrão $(n=12)$. *Diferença estatisticamente significante $(p<0,05)$.

\subsubsection{Avaliação Histopatológica}

A análise qualitativa da celularidade e do infiltrado inflamatório foi realizada pela coloração das lâminas por hematoxilina-eosina. No $2^{\circ}$ dia após o procedimento cirúrgico, observou-se infiltrado inflamatório importante em todos os grupos (Figura 24a, d, g).

No 70 dia, lâminas correspondentes a todos os grupos apresentaram evidência de atividade fibroblástica, e aquelas correspondentes às úlceras tratadas com solução fisiológica (Figura 24b) e creme a 10\% de óleo-resina (Figura 24h) ainda apresentavam certo grau de inflamação.

No $14^{\circ}$ dia, as lâminas correspondentes às úlceras tratadas com creme a 10\% de óleo-resina de copaíba (Figura 24i) apresentaram menos fibroblastos que aquelas correspondentes às úlceras tratadas com solução fisiológica (Figura 24c) e creme base (Figura 24f). 
A análise qualitativa da colagênese também foi realizada pela coloração das lâminas com o tricrômio de Gomori (Figura 25). Em todos os grupos avaliados, a intensidade de cor na área da úlcera/tecido cicatricial aumentou gradualmente durante o seguimento indicando, qualitativamente, aumento da colagênese. Quando comparou-se as lâminas no $14^{\circ}$ dia, a intensidade de coloração parecia estar discretamente aumentada nas lâminas correspondentes às úlceras tratadas com creme base (Figura 25f) e creme a 10\% de óleo-resina (Figura 25i) comparada ao grupo solução fisiológica (Figura 25c).
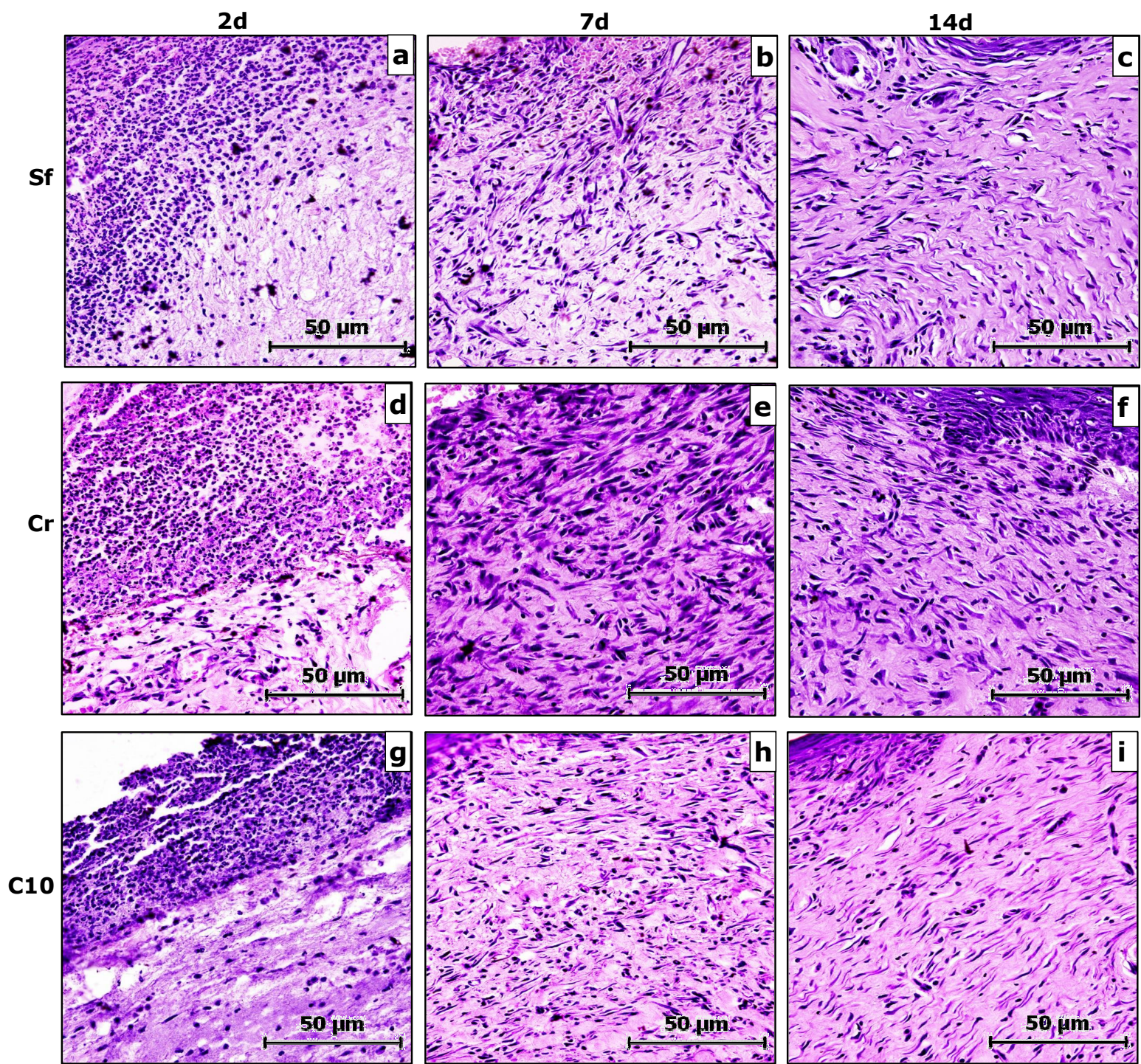

Figura 24 - Avaliação histopatológica das úlceras nos dias 2, 7 e 14 respectivamente, conforme os tratamentos: Solução fisiológica (Sf) (a-c); Creme base (Cr) (d-f); Creme a $10 \%$ de óleo-resina de copaíba (C10) (g-i). Coloração hematoxilina-eosina. Aumento de $400 x$. 

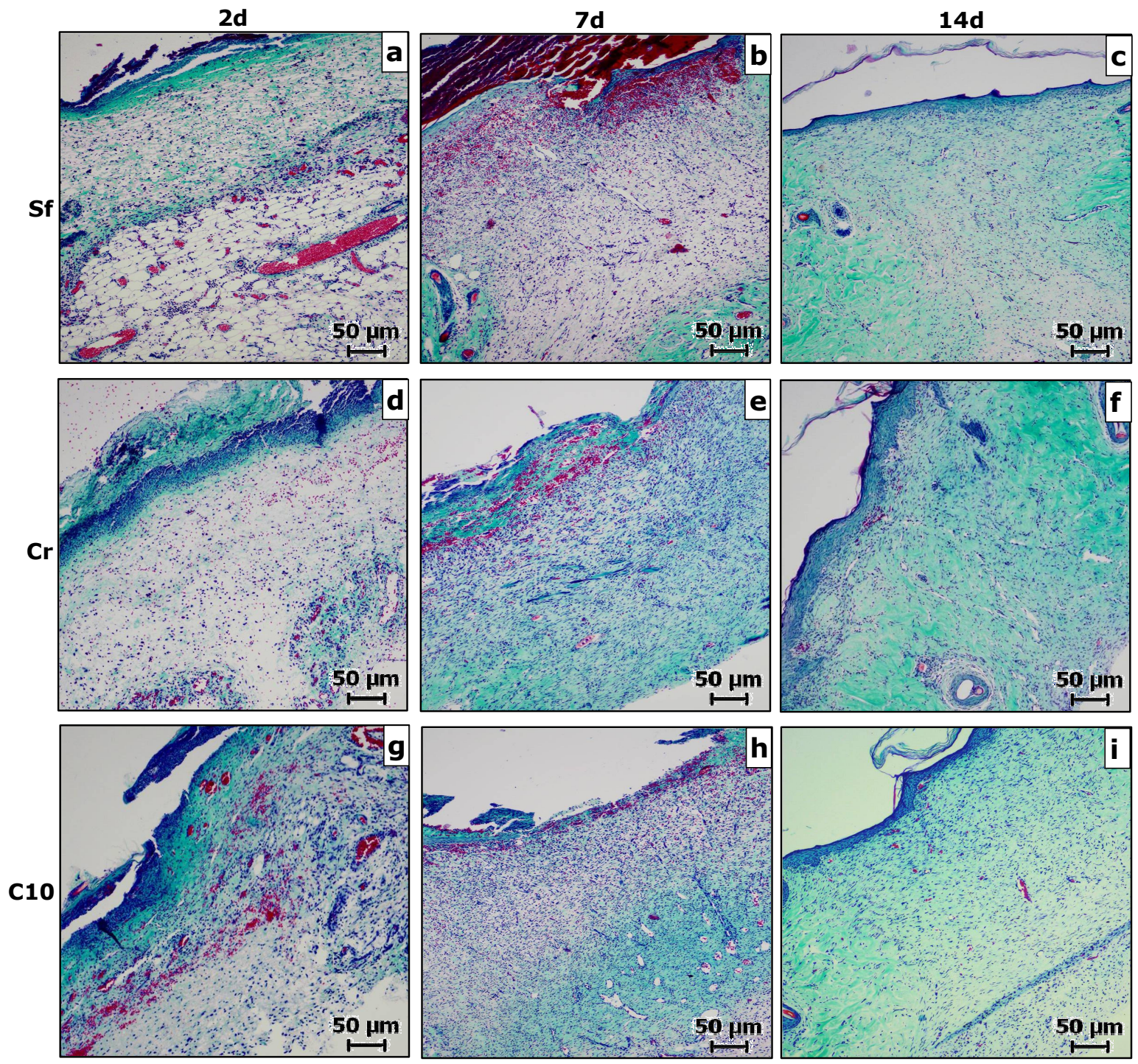

Figura 25 - Avaliação histopatológica das úlceras nos dias 2, 7 e 14 respectivamente, conforme os tratamentos: Solução fisiológica (Sf) (a-c); Creme base (Cr) (d-f); Creme a $10 \%$ de óleo-resina de copaíba (C10) ( $\mathbf{g}-\mathbf{i})$. Coloração tricrômio de Gomori. Aumento de $100 x$.

\subsubsection{Avaliação Bioquímica: Dosagem de Hidroxiprolina}

Após obter-se o peso seco de cada biópsia as mesmas foram processadas para a análise quantitativa da colagênese através da dosagem de hidroxiprolina. Ao final do experimento, realizou-se a leitura de absorbância das microplacas de 96 poços. A partir dos valores de absorbância a $550 \mathrm{~nm}$ das amostras correspondentes à curva padrão, procedeu-se à construção da equação da reta e 
então aos cálculos das concentrações desconhecidas de hidroxiprolina em microgramas por miligrama de tecido seco.

A Figura 26 representa a imagem digitalizada de uma microplaca utilizada na dosagem de hidroxiprolina. Desenvolvimento da coloração avermelhada representando a formação do cromóforo (indicativo da presença de hidroxiprolina) após a reação das amostras e das soluções padrão com o reagente de Ehrlich (KOKANE et al., 2009).

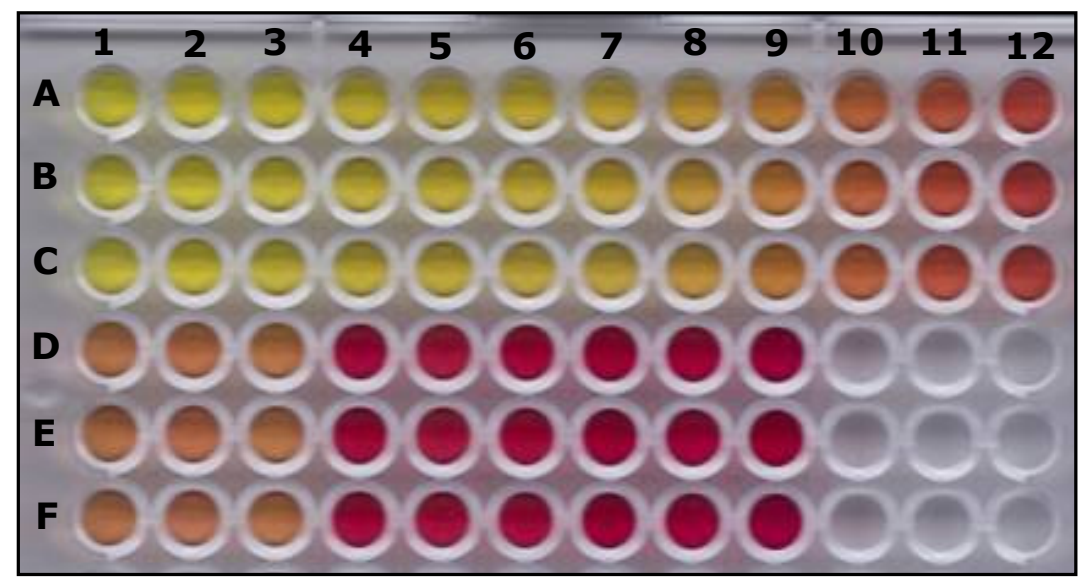

Figura 26 - Imagem digitalizada de uma microplaca utilizada para a dosagem de hidroxiprolina. As colunas 1 a 12 e fileiras $A$ a $C$ representam a curva padrão de hidroxiprolina, nas concentrações: 1,$0 ; 2,0 ; 4,0 ; 6,0 ; 8,0 ; 10 ; 20 ; 40 ; 60 ; 80$ e 100 $\mu \mathrm{g} / \mathrm{mL}$, em triplicata. As fileiras $D$ a $F$, representam triplicatas de biópsias colhidas de um único grupo de tratamento, no $2^{\circ}$ dia (colunas 1 a 3), 70 dia (colunas 4 a 6 ) e $14^{\circ}$ dia (colunas 7 a 9 ) após procedimento cirúrgico.

Houve aumento progressivo da concentração de hidroxiprolina durante o tempo de seguimento das úlceras em todos os grupos de tratamento (Figura 27). Diferenças estatisticamente significantes foram observadas do 20 para 0 $14^{\circ}$ dia de seguimento em todos os grupos $(p<0,001)$; do $2^{\circ}$ para 070 dia nas úlceras tratadas com creme a $10 \%$ de óleo-resina de copaíba $(p<0,001)$; do 70 para o $14^{\circ}$ dia nas úlceras tratadas com solução fisiológica $(p<0,01)$, creme base $(p<0,05)$ e creme a $10 \%$ de óleo-resina $(p<0,01)$.

Quando se comparou os tratamentos por dia de seguimento, o tratamento com creme a $10 \%$ de óleo-resina apresentou um possível efeito positivo na colagênese (maior concentração de hidroxiprolina) comparado aos tratamentos controles no $7^{\circ}$ e $14^{\circ}$ dias, com diferença estatisticamente significante $\left[\mathrm{C} 10 \times \mathrm{Cr}\right.$ no $14^{\circ}$ dia de seguimento $\left.(p<0,05)\right]$. 


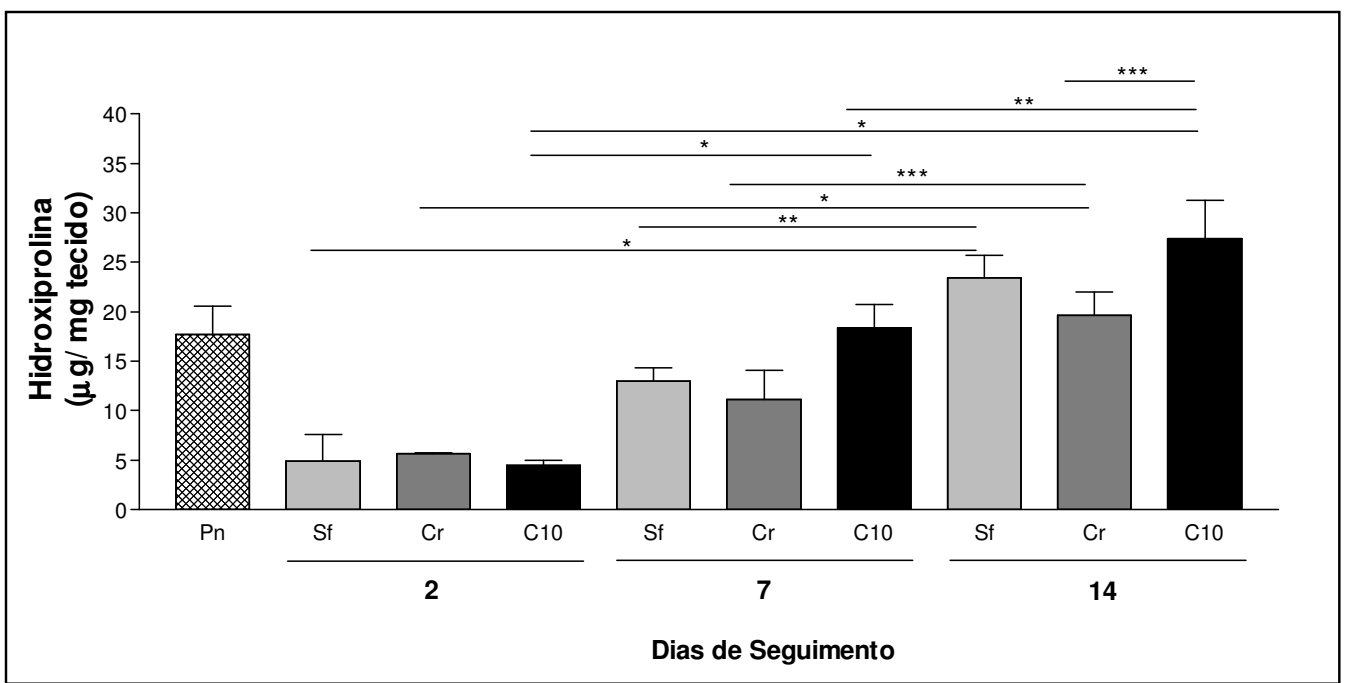

Figura 27 - Concentração de hidroxiprolina durante o seguimento das úlceras nos dias 2, 7 e 14, conforme os tratamentos: Solução fisiológica (Sf), Creme base ( $\mathrm{Cr}$ ) e Creme a $10 \%$ de óleo-resina de copaíba (C10). Incluíu-se a análise da concentração de hidroxiprolina em pele normal de ratos, representado no gráfico pela sigla $\mathrm{Pn}$. Os valores representam a média \pm desvio-padrão da análise em triplicata $(n=3)$. Diferenças estatisticamente significantes: $(*) p<0,001 ;(* *) p<0,01$ e $(* * *) p<0,05$

\subsubsection{Avaliação Bioquímica: Dosagem de Metaloproteinases}

Após a determinação da concentração de proteínas totais nas biópsias e da realização da zimografia em gelatina, as metaloproteinases presentes nas amostras foram identificadas por comparação ao padrão de peso molecular e a atividade enzimática foi visualizada a partir dos géis de zimografia (zimogramas), sendo que as bandas claras em um fundo azul representam as áreas de proteólise no substrato de proteína (gelatina).

A Figura 28 representa a imagem digitalizada de um dos géis após a zimografia, demonstrando a presença da atividade proteolítica nas amostras. Comparadas ao padrão de peso molecular, as bandas de atividade proteolítica exibiram pesos moleculares de aproximadamente $66 \mathrm{kDa}, 72 \mathrm{kDa}$ e 92 kDa, sugerindo, respectivamente, a presença das metaloproteinases 2 (ativa; pró ou inativa) e 9 , representadas pelas bandas claras. 


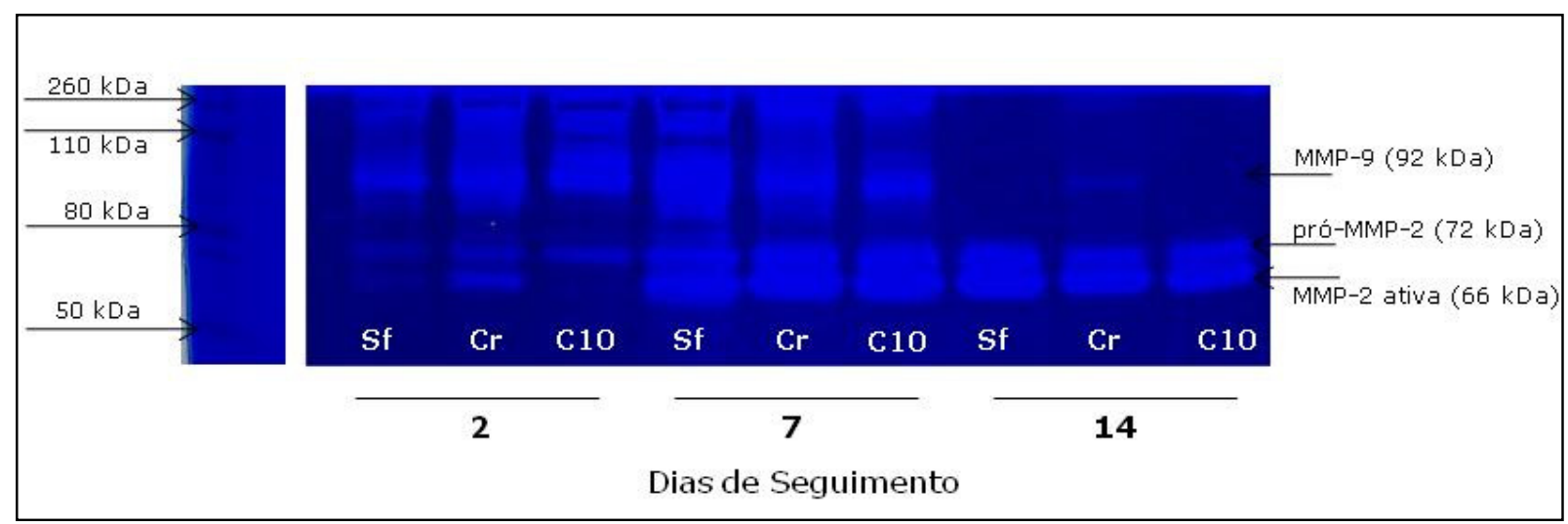

Figura 28. Imagem digitalizada do gel de zimografia (zimograma) representando a atividade proteolítica das MMPs durante o seguimento das úlceras nos dias 2, 7 e 14, conforme os tratamentos: Solução fisiológica (Sf), Creme base (Cr) e Creme a 10\% de óleo-resina de copaíba (C10). As bandas coradas em azul escuro representam o padrão de peso molecular

Apesar das diferenças na intensidade das bandas de atividade proteolítica serem visualizadas no gel, estas foram quantificadas por densitometria, por meio da leitura da intensidade média das bandas (em pixels) com o auxílio do software ImageJ, a partir das imagens digitalizadas dos zimogramas. Para a quantificação das bandas os géis foram feitos em triplicata e amostras correspondentes a todos os tratamentos durante todo o período de seguimento foram colocadas em cada gel.

Houve aumento progressivo da atividade da MMP-2 ativa durante o período de seguimento para as úlceras tratadas com solução fisiológica e creme a $10 \%$ de óleo-resina de copaíba, enquanto para aquelas tratadas com creme base houve aumento de atividade enzimática do $2^{\circ}$ para o 70 dia e diminuição do 70 para o 140 dia de seguimento (Figura 29a). Diferenças estatisticamente significantes foram observadas do $2^{\circ}$ para o 140 dia nas úlceras tratadas com solução fisiológica $(p<0,05)$ e creme a $10 \%$ de óleo-resina $(p<0,01)$; do 20 para o 70 dia nas úlceras tratadas com creme base $(p<0,05)$ e creme a $10 \%$ de óleoresina $(p<0,01)$.

A atividade da pró-MMP-2 manteve-se praticamente inalterada durante o período de seguimento nas úlceras tratadas com solução fisiológica (Figura 29b). Nas úlceras tratadas com creme base houve aumento de atividade do 20 para o 70 dia de seguimento e diminuição do 70 para o 140 dia. Nas úlceras tratadas com creme a $10 \%$ de óleo-resina a atividade proteolítica da pró-MMP-2 aumentou progressivamente durante o seguimento e no 140 dia, a atividade 
enzimática neste grupo foi superior à atividade observada nos grupos controles. Porém, sem diferenças estatisticamente significantes.

Houve diminuição progressiva da atividade da MMP-9 durante o período de seguimento para todos os grupos (Figura 29c). Diferenças estatisticamente significantes foram observadas do $2^{\circ}$ para o $14^{\circ}$ dia nas úlceras tratadas com solução fisiológica $(p<0,001)$, creme base $(p<0,01)$ e creme a $10 \%$ de óleoresina $(p<0,05)$; do 20 para o 70 dia nas úlceras tratadas com creme base $(p<0,05)$ e creme a $10 \%$ de óleo-resina $(p<0,05)$. No $14^{\circ}$ dia nenhuma atividade proteolítica da MMP-9 foi encontrada nas úlceras tratadas com creme a $10 \%$ de óleo-resina. 


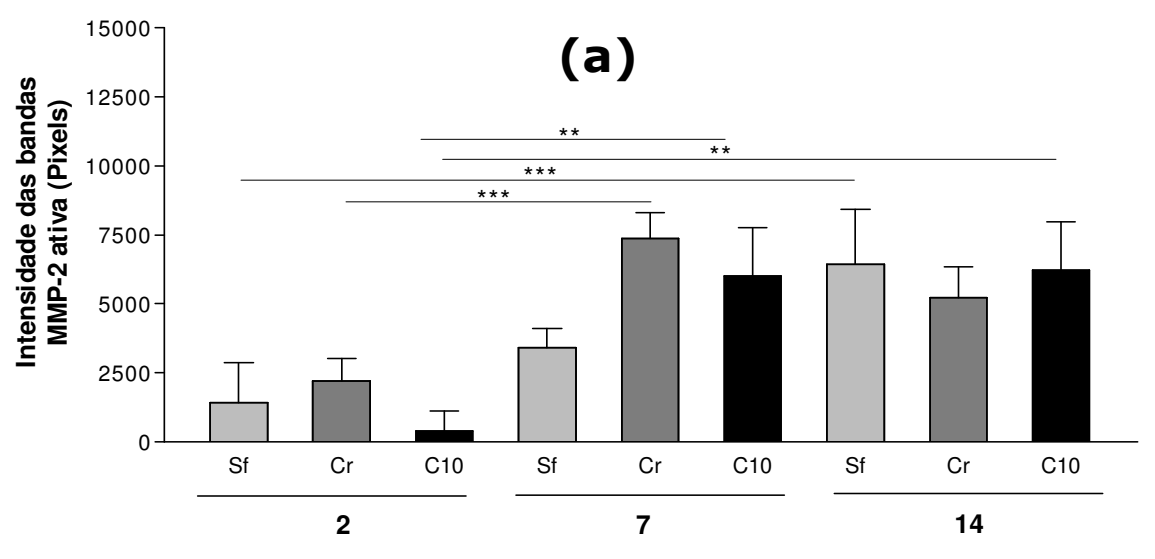

Dias de Seguimento

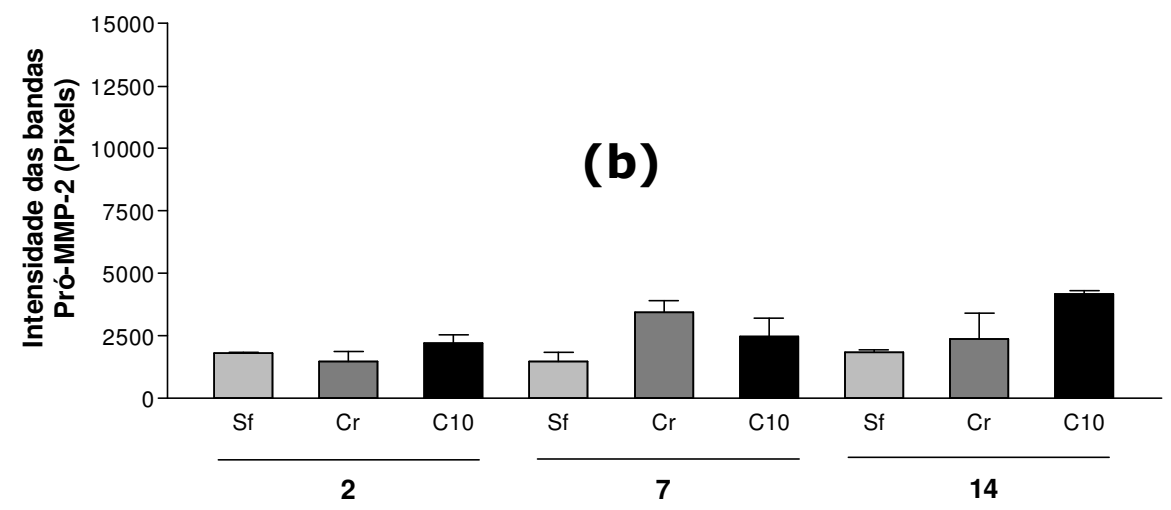

Dias de Seguimento

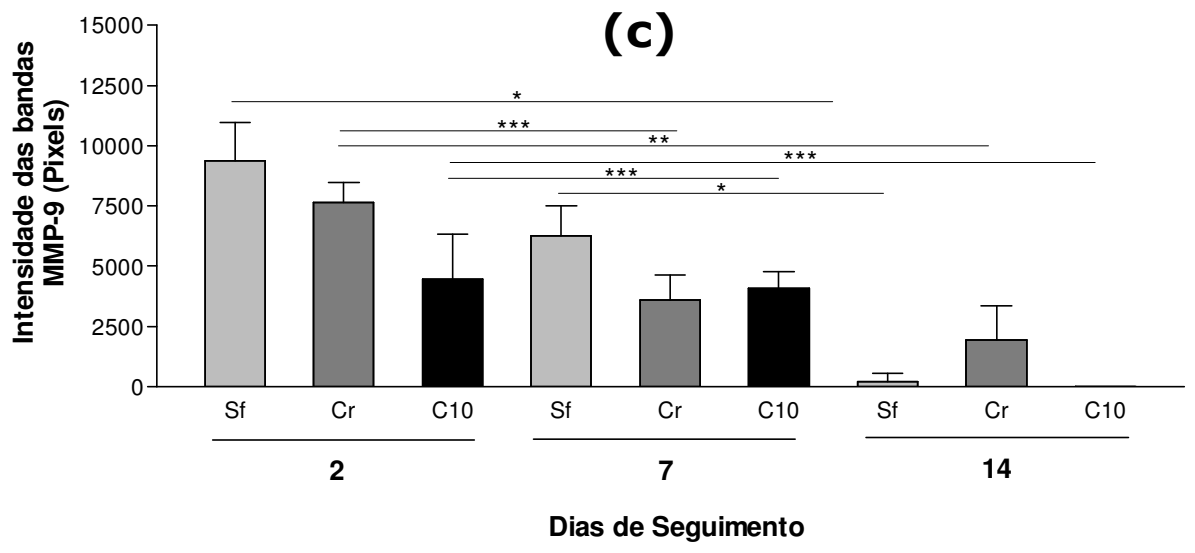

Figura 29 - Atividade das metaloproteinases 2 (a, b) e 9 (c) durante o seguimento das úlceras nos dias 2, 7 e 14, conforme os tratamentos: Solução fisiológica (Sf), Creme base $(\mathrm{Cr})$ e Creme a $10 \%$ de óleo-resina de copaíba (C10). Os valores representam a média \pm desvio-padrão da medida da intensidade das bandas, em triplicata, a partir dos zimogramas $(n=3)$. Diferenças estatisticamente significantes: $\left(^{*}\right) p<0,001,\left(^{* *}\right) p<0,01$ e $(* * *) p<0,05$. 


\subsection{ESTUDO 4: Efeito do óleo-resina de copaíba no modelo ex vivo de cicatrização da pele humana (culturas organotípicas de explantes de pele humana)}

Foram realizadas culturas a partir de fragmentos de pele de três pacientes diferentes, e todos os tratamentos avaliados foram aplicados em cada pele proveniente de cada paciente, constituindo o estudo em triplicata. Primeiramente foi observado que é possível manter a pele em cultura por até 21 dias. Nas Figuras 30 (a-e), observa-se alteração na cor do meio de cultura, que é indicativo de viabilidade/proliferação celular. Nos fragmentos que receberam apenas o meio de cultura parece ter havido diminuição da hidratação natural da pele (Figuras 30a), uma vez que os fragmentos apresentavam-se ressecados, especialmente ao final do período de avaliação. Nos fragmentos que receberam o creme base (Figura 30b) e creme a 10\% de óleo-resina de copaíba (Figura 30c), alterações macroscópicas na pele não foram observadas. Nos fragmentos que receberam creme a $25 \%$ de óleo-resina, houve um escurecimento dos fragmentos a partir do 70 dia (Figura 30d). Nos fragmentos que receberam 0 óleo-resina in natura, houve escurecimento da pele a partir do $3^{\circ}$ dia (Figura 30e). 


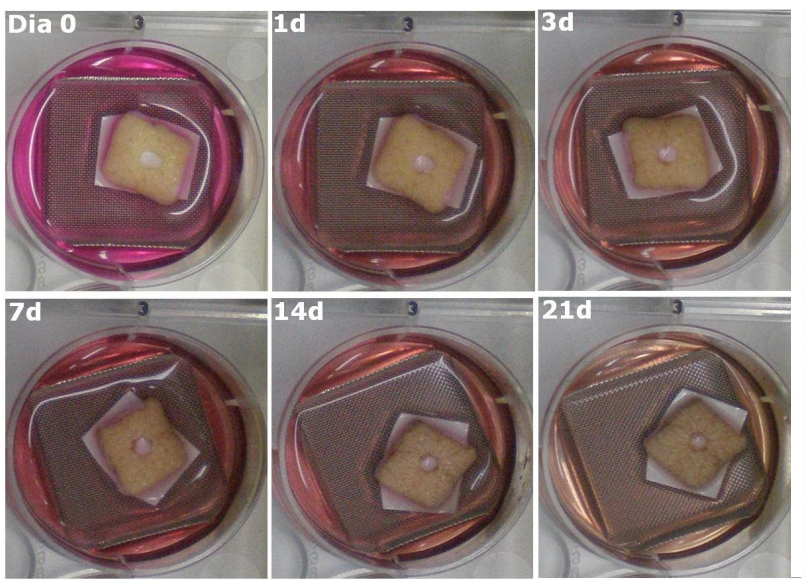

(a)

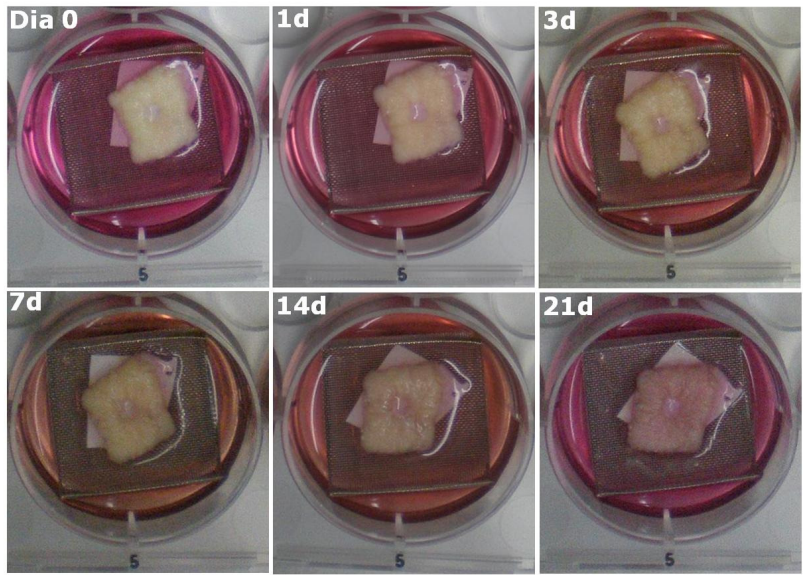

(c)

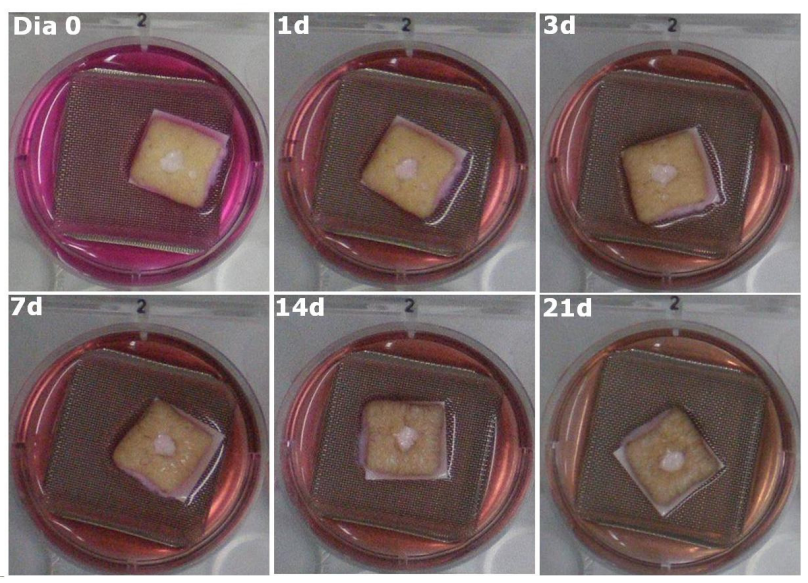

(b)

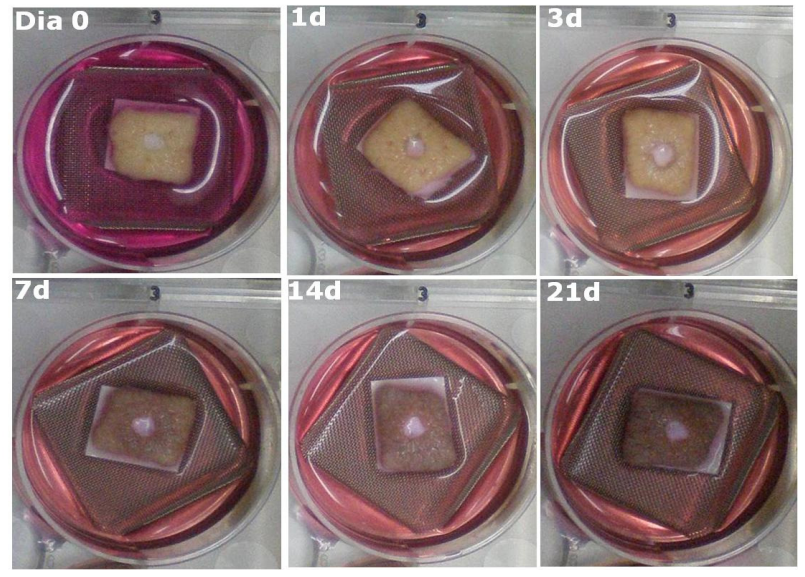

(d)

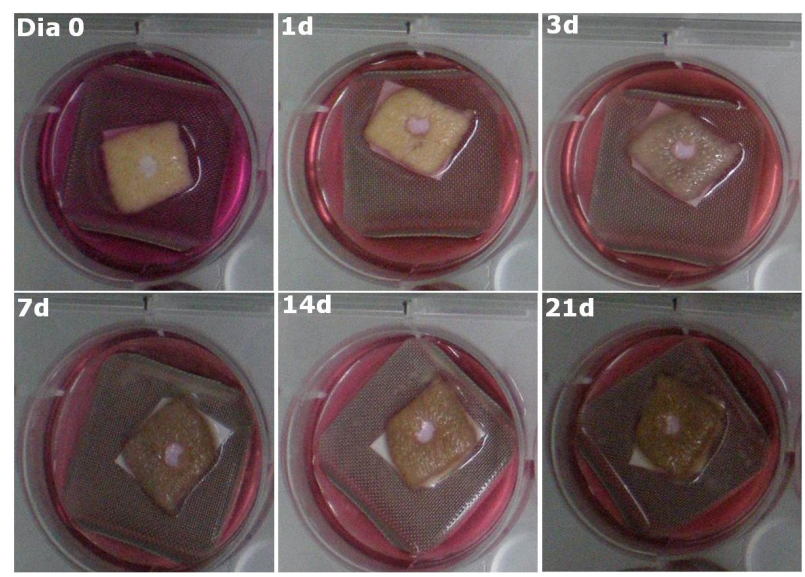

(e)

Figura 30 - Representação fotográfica dos fragmentos de pele humana em cultura nos dias $0,1,3,7,14$ e 21, conforme os tratamentos: Meio de cultura DMEM (a); Creme base (b); Cremes a $10 \%$ (c) e a $25 \%$ (d) de óleo-resina de copaíba; Óleo-resina puro (e). 
A avaliação histológica dos fragmentos foi realizada pela coloração das lâminas por hematoxilina-eosina. Não houve diferenças entre os grupos tratados. Entretanto, para os fragmentos que não receberam tratamento, ou seja, aqueles fragmentos que apenas foram mantidos no meio de cultura, importantes modificações durante o tempo de seguimento foram observadas (Figura 31a-f). Vinte e quatro horas após o início da cultura dos fragmentos (Figura 31b) havia maior distensibilidade da úlcera em relação ao início do experimento (Figura 31a). No $3^{\circ}$ dia de cultura, havia maior contratilidade da úlcera em relação ao $1^{\circ}$ dia (Figura 31c). No 70 dia foi possível evidenciar o revestimento da área ulcerada com um novo epitélio (Figura 31d). No $14^{\circ}$ dia, o novo epitélio apresentava-se revestido por uma camada córnea paraceratótica (Figura 31e) e no final do seguimento das culturas (21 dias) observou-se a reepitelização completa do local ulcerado (Figura 31e). 



Figura 31 - Avaliação histopatológica dos fragmentos de pele humana mantidos no meio de cultura (DMEM) nos tempos: 0 (a), 1 (b), 3 (c), 7 (d), 14 (e) e 21 dias (f). Coloração hematoxilina-eosina. Aumento de 100x. Setas contínuas (início da ulceração), setas tracejadas (revestimento de um novo epitélio), camada córnea $\left(^{*}\right)$, novo epitélio (\#). 


\subsection{ESTUDO 5: Avaliação da atividade antimicrobiana in vitro do óleo- resina de copaíba.}

\subsubsection{Padronização do cultivo e curva de crescimento bacteriano}

Diferentes meios de culturas foram avaliados para os microrganismos estudados. Na Tabela 2 encontram-se os meios testados para cada microrganismo, o que correspondeu à primeira etapa da avaliação, ou seja, determinar o meio mais adequado para a determinação da fase exponencial durante o crescimento de cada microrganismo. Esta determinação é importante uma vez evidencia-se o crescimento exponencial dos microrganismos e a metade da fase log desta curva representa o período de tempo quando os microrganismos expressam ao máximo seus caracteres fisiológicos (TORTORA; FUNKE; CASE, 2005).

Diante destes resultados, os meios em destaque na tabela 2 foram selecionados para a incubação prévia à determinação da Concentração Inibitória Mínima e da Concentração Bactericida Mínima do óleo-resina de copaíba.

Desta forma, o tempo de cultivo foi estabelecido, dentro das condições experimentais padronizadas, no ponto médio, ou seja, na metade da fase log da curva de crescimento exponencial da cultura, que relaciona a absorbância do meio de cultura em $660 \mathrm{~nm}$, em função do tempo de incubação a $37^{\circ} \mathrm{C}$ (Figuras 32 e 33 ). 
Tabela 2 - Microrganismos, meios de cultura avaliados e resultados observados.

\begin{tabular}{|c|c|c|}
\hline Microrganismo & $\begin{array}{l}\text { Meio de } \\
\text { cultura }\end{array}$ & Resultado \\
\hline \multirow{3}{*}{ S. aureus } & $\mathrm{MHb}$ & Não apresentou crescimento exponencial \\
\hline & $\mathrm{BHI}$ & Curva satisfatória. Metade da fase $\log =5$ horas \\
\hline & TSB & Curva satisfatória. Metade da fase log $=5$ horas \\
\hline \multirow{2}{*}{ S. pyogenes } & $\mathrm{BHI}$ & Curva satisfatória. Metade da fase log $=4$ horas \\
\hline & TSB & Curva satisfatória. Metade da fase $\log =4$ horas \\
\hline \multirow{2}{*}{ E. faecalis } & BHI+Glicose & Curva satisfatória. Metade da fase log = 3 horas \\
\hline & $B H I$ & Curva satisfatória. Metade da fase log $=3$ horas \\
\hline \multirow{3}{*}{ E. coli } & $\mathrm{MHb}$ & Não apresentou crescimento exponencial \\
\hline & $\mathrm{BHI}$ & Curva satisfatória. Metade da fase log = 3 horas \\
\hline & TSB & Curva satisfatória. Metade da fase log $=3$ horas \\
\hline \multirow{5}{*}{ P. aeruginosa } & $\mathrm{MHb}$ & Não apresentou crescimento exponencial \\
\hline & $\mathrm{BHI}$ & Não apresentou crescimento exponencial \\
\hline & TSB & Não apresentou crescimento exponencial \\
\hline & Água Peptonada & Não apresentou crescimento exponencial \\
\hline & Caldo Nutriente & $\begin{array}{l}\text { Curva c/ tendência exponencial (Metade da fase } \\
\qquad \log =5 \text { horas) }\end{array}$ \\
\hline
\end{tabular}

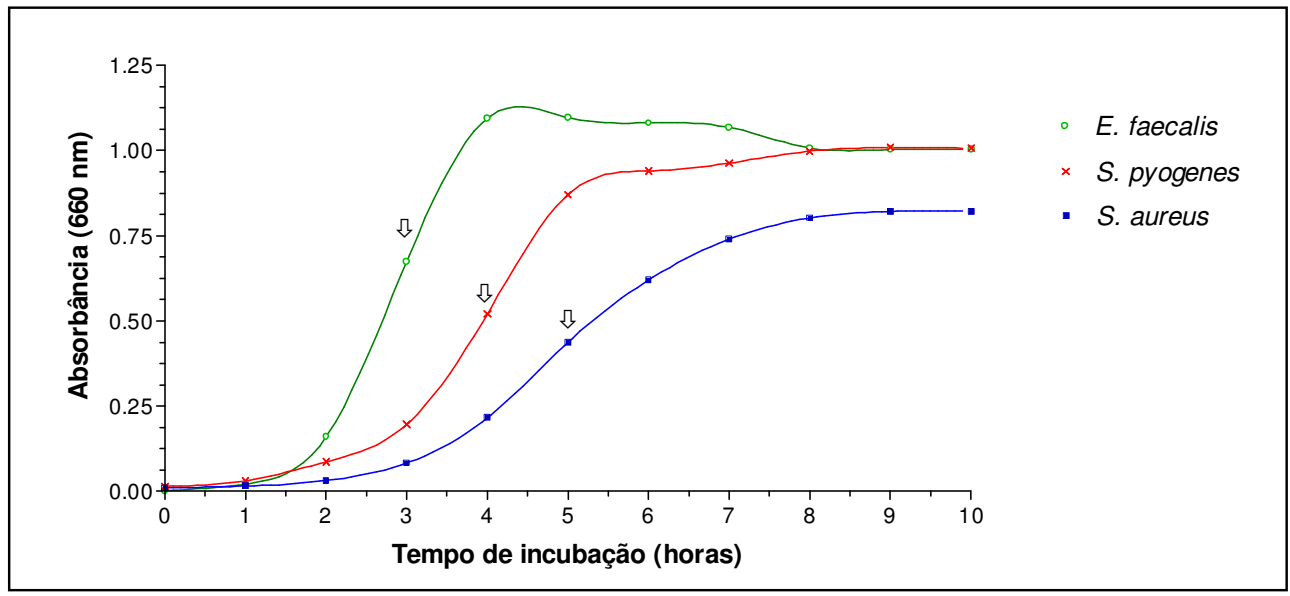

Figura 32 - Curvas de crescimento para os microrganismos Gram-Positivos E. faecalis, S. pyogenes, S. aureus, em meio de cultura BHI. As setas representam a metade da fase logarítmica de crescimento (3, 4 e 5 horas de incubação, respectivamente). 


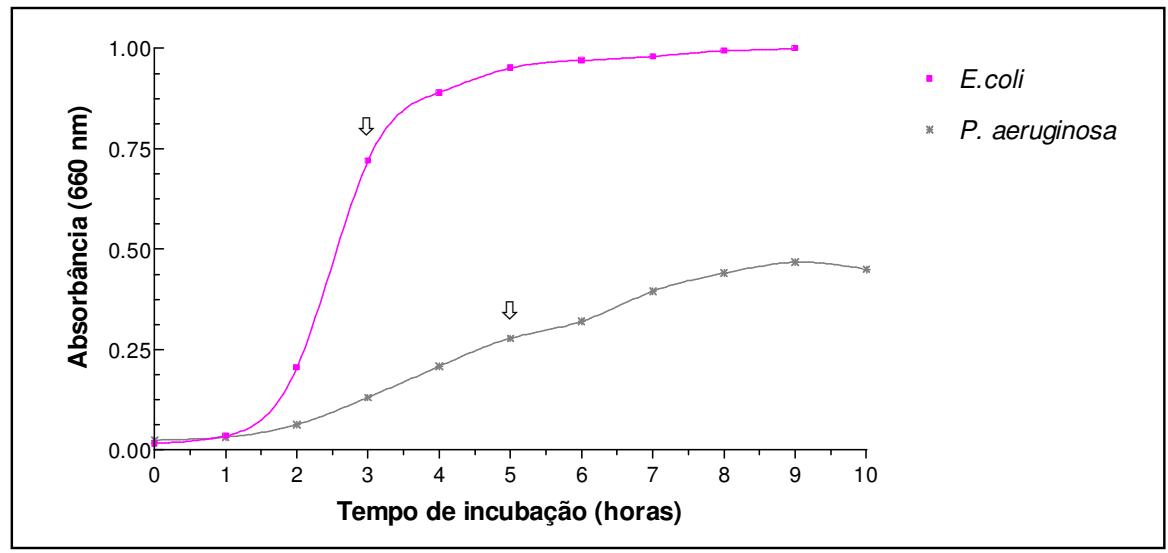

Figura 33 - Curvas de crescimento para os microrganismos Gram-Negativos: E. coli, em meio de cultura BHI; $P$. aeruginosa, em meio de cultura Caldo Nutriente. As setas representam a metade da fase logarítmica de crescimento (3 e 5 horas de incubação, respectivamente).

\subsubsection{Determinação da Concentração Inibitória Mínima (CIM)}

Primeiramente prepararam-se as soluções do óleo-resina de copaíba, observando-se a homogeneidade das mesmas logo após sua obtenção e após repouso dos frascos. As soluções mantiveram-se homogêneas, ou seja, não se verificaram partículas oleosas imiscíveis, indicando que as soluções estavam adequadas para o teste.

A determinação da CIM do óleo-resina de copaíba sobre o crescimento dos microrganismos foi realizada em microplacas de cultivo com 96 poços em virtude de sua sensibilidade, simplicidade de execução e rapidez, uma vez que várias concentrações do produto podem testadas em um único ensaio (LIBANORE, 2008; GABRIELSON; HART; JARELOV, 2002).

A CIM do óleo-resina da copaíba verificada para a bactéria $S$. aureus foi igual a $200 \mu \mathrm{g} / \mathrm{mL}$ (Figura 34; Quadro 4), ou seja, esta foi menor concentração do óleo-resina onde não mais se observou crescimento bacteriano visível (ausência de coloração). O crescimento bacteriano foi indicado pela coloração azul produzido pela metabolização bacteriana do sal de tetrazólio e a morte bacteriana indicada pela ausência de coloração. As concentrações do óleo-resina variaram entre $1,5 \mathrm{mg} / \mathrm{mL}$ a $3,12 \mu \mathrm{g} / \mathrm{mL}(\mathrm{v} / \mathrm{v})$ e a partir de $100 \mu \mathrm{g} / \mathrm{mL}$ o microrganismo S. aureus não apresentou sensibilidade ao óleo-resina de copaíba, observado pela presença da coloração azul. 


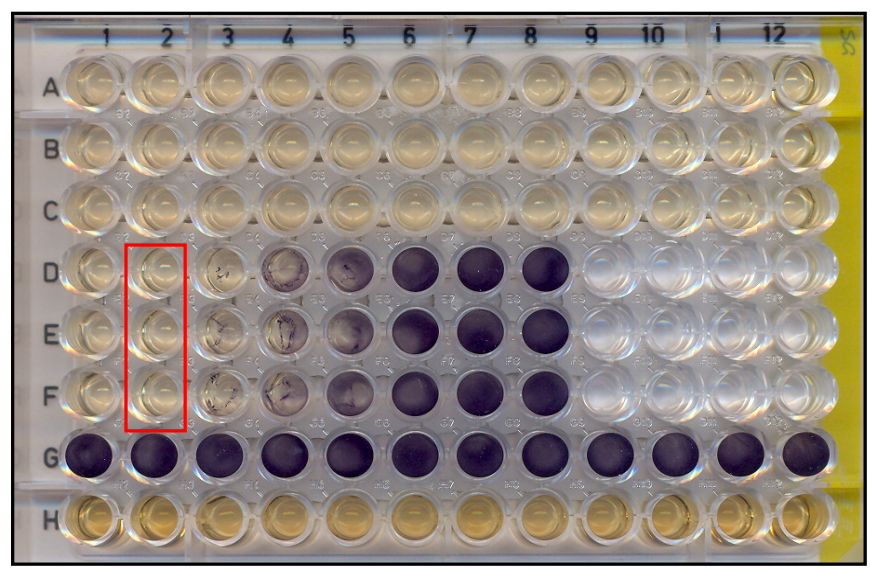

Figura 34 - Imagem digitalizada da microplaca de cultura para a determinação da CIM para o microrganismo S. aureus. Valor da CIM igual a $200 \mu \mathrm{g} / \mathrm{mL}$.

Quadro 4 - Representação do protocolo experimental para a determinação da CIM, referente à figura 34.

\begin{tabular}{|c|c|c|c|c|c|c|c|c|c|c|c|c|}
\hline & 1 & 2 & 3 & 4 & 5 & 6 & 7 & 8 & 9 & 10 & 11 & 12 \\
\hline A & $1,5 \mathrm{mg} / \mathrm{mL}$ & $1,4 \mathrm{mg} / \mathrm{mL}$ & $1,3 \mathrm{mg} / \mathrm{mL}$ & $1,2 \mathrm{mg} / \mathrm{mL}$ & $1,1 \mathrm{mg} / \mathrm{mL}$ & $1,0 \mathrm{mg} / \mathrm{mL}$ & $900 \mu \mathrm{g} / \mathrm{mL}$ & $800 \mu \mathrm{g} / \mathrm{mL}$ & $700 \mu \mathrm{g} / \mathrm{mL}$ & $600 \mu \mathrm{g} / \mathrm{mL}$ & $500 \mu \mathrm{g} / \mathrm{mL}$ & $400 \mu \mathrm{g} / \mathrm{mL}$ \\
\hline B & $1,5 \mathrm{mg} / \mathrm{mL}$ & $1,4 \mathrm{mg} / \mathrm{mL}$ & $1,3 \mathrm{mg} / \mathrm{mL}$ & $1,2 \mathrm{mg} / \mathrm{mL}$ & $1,1 \mathrm{mg} / \mathrm{mL}$ & $1,0 \mathrm{mg} / \mathrm{mL}$ & $900 \mu \mathrm{g} / \mathrm{mL}$ & $800 \mu \mathrm{g} / \mathrm{mL}$ & $700 \mu \mathrm{g} / \mathrm{mL}$ & $600 \mu \mathrm{g} / \mathrm{mL}$ & $500 \mu \mathrm{g} / \mathrm{mL}$ & $400 \mu \mathrm{g} / \mathrm{mL}$ \\
\hline C & $1,5 \mathrm{mg} / \mathrm{mL}$ & $1,4 \mathrm{mg} / \mathrm{mL}$ & $1,3 \mathrm{mg} / \mathrm{mL}$ & $1,2 \mathrm{mg} / \mathrm{mL}$ & $1,1 \mathrm{mg} / \mathrm{mL}$ & $1,0 \mathrm{mg} / \mathrm{mL}$ & $900 \mu \mathrm{g} / \mathrm{mL}$ & $800 \mu \mathrm{g} / \mathrm{mL}$ & $700 \mu \mathrm{g} / \mathrm{mL}$ & $600 \mu \mathrm{g} / \mathrm{mL}$ & $500 \mu \mathrm{g} / \mathrm{mL}$ & $400 \mu \mathrm{g} / \mathrm{mL}$ \\
\hline $\mathbf{E}$ & $300 \mu \mathrm{g} / \mathrm{mL}$ & $200 \mu \mathrm{g} / \mathrm{mL}$ & $100 \mu \mathrm{g} / \mathrm{mL}$ & $50 \mu \mathrm{g} / \mathrm{mL}$ & $25 \mu \mathrm{g} / \mathrm{mL}$ & $\begin{array}{c}12,5 \\
\mu \mathrm{g} / \mathrm{mL}\end{array}$ & $\begin{array}{c}6,25 \\
\mu \mathrm{g} / \mathrm{mL}\end{array}$ & $\begin{array}{c}3,12 \\
\mu \mathrm{g} / \mathrm{mL}\end{array}$ & & & & \\
\hline $\mathbf{F}$ & $300 \mu \mathrm{g} / \mathrm{mL}$ & $200 \mu \mathrm{g} / \mathrm{mL}$ & $100 \mu \mathrm{g} / \mathrm{mL}$ & $50 \mu \mathrm{g} / \mathrm{mL}$ & $25 \mu \mathrm{g} / \mathrm{mL}$ & $\begin{array}{c}12,5 \\
\mu \mathrm{g} / \mathrm{mL}\end{array}$ & $\begin{array}{c}6,25 \\
\mu \mathrm{g} / \mathrm{mL}\end{array}$ & $\begin{array}{c}3,12 \\
\mu \mathrm{g} / \mathrm{mL}\end{array}$ & & & & \\
\hline G & $\begin{array}{l}\text { Controle } \\
\text { positivo }\end{array}$ & $\begin{array}{l}\text { Controle } \\
\text { positivo }\end{array}$ & $\begin{array}{l}\text { Controle } \\
\text { positivo }\end{array}$ & $\begin{array}{l}\text { Controle } \\
\text { positivo }\end{array}$ & $\begin{array}{l}\text { Controle } \\
\text { positivo }\end{array}$ & $\begin{array}{l}\text { Controle } \\
\text { positivo }\end{array}$ & $\begin{array}{l}\text { Controle } \\
\text { positivo }\end{array}$ & $\begin{array}{l}\text { Controle } \\
\text { positivo }\end{array}$ & $\begin{array}{l}\text { Controle } \\
\text { positivo }\end{array}$ & $\begin{array}{l}\text { Controle } \\
\text { positivo }\end{array}$ & $\begin{array}{l}\text { Controle } \\
\text { positivo }\end{array}$ & $\begin{array}{l}\text { Controle } \\
\text { positivo }\end{array}$ \\
\hline H & $\begin{array}{l}\text { Controle } \\
\text { esterilidade }\end{array}$ & $\begin{array}{c}\text { Controle } \\
\text { esterilidade }\end{array}$ & $\begin{array}{l}\text { Controle } \\
\text { esterilidade }\end{array}$ & $\begin{array}{l}\text { Controle } \\
\text { esterilidade }\end{array}$ & $\begin{array}{c}\text { Controle } \\
\text { esterilidade }\end{array}$ & $\begin{array}{l}\text { Controle } \\
\text { esterilidade }\end{array}$ & $\begin{array}{c}\text { Controle } \\
\text { esterilidade }\end{array}$ & $\begin{array}{c}\text { Controle } \\
\text { esterilidade }\end{array}$ & $\begin{array}{c}\text { Controle } \\
\text { esterilidade }\end{array}$ & $\begin{array}{l}\text { Controle } \\
\text { esterilidade }\end{array}$ & $\begin{array}{l}\text { Controle } \\
\text { esterilidade }\end{array}$ & $\begin{array}{c}\text { Controle } \\
\text { esterilidade }\end{array}$ \\
\hline
\end{tabular}

A CIM do óleo-resina de copaíba verificada para a bactéria $S$. pyogenes foi igual a $400 \mu \mathrm{g} / \mathrm{mL}$ (Figura 35; Quadro 5). As concentrações do óleo-resina variaram entre $1,0 \mathrm{mg} / \mathrm{mL}$ a $1,6 \mu \mathrm{g} / \mathrm{mL}(\mathrm{v} / \mathrm{v})$ e a partir de $200 \mu \mathrm{g} / \mathrm{mL}$ o microrganismo S. pyogenes não apresentou sensibilidade ao óleo-resina. 


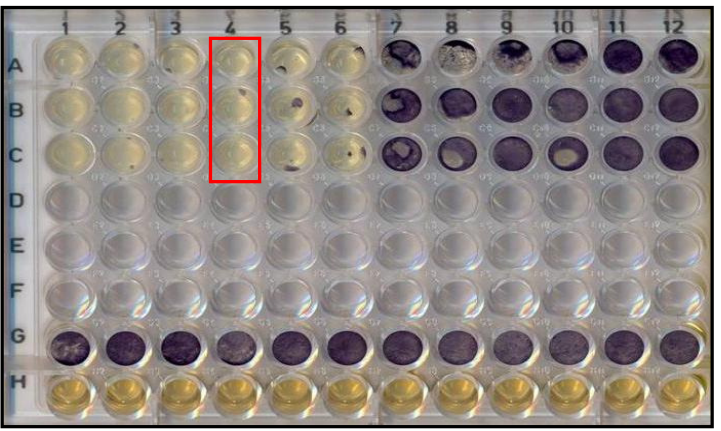

Figura 35 - Imagem digitalizada da microplaca de cultura para a determinação da CIM para o microrganismo S. pyogenes. Valor da CIM igual a $400 \mu \mathrm{g} / \mathrm{mL}$.

Quadro 5 -. Representação do protocolo experimental para a determinação da CIM, referente à figura 35.

\begin{tabular}{|c|c|c|c|c|c|c|c|c|c|c|c|c|}
\hline & 1 & 2 & 3 & 4 & 5 & 6 & 7 & 8 & 9 & 10 & 11 & 12 \\
\hline A & $1 \mathrm{mg} / \mathrm{mL}$ & $0,8 \mathrm{mg} / \mathrm{mL}$ & $0,6 \mathrm{mg} / \mathrm{mL}$ & $0,4 \mathrm{mg} / \mathrm{mL}$ & $200 \mu \mathrm{g} / \mathrm{mL}$ & $100 \mu \mathrm{g} / \mathrm{mL}$ & $50 \mu \mathrm{g} / \mathrm{mL}$ & $25 \mu \mathrm{g} / \mathrm{mL}$ & $\begin{array}{c}12,5 \\
\mu \mathrm{g} / \mathrm{mL}\end{array}$ & $\begin{array}{c}6,25 \\
\mu \mathrm{g} / \mathrm{mL}\end{array}$ & $\begin{array}{c}3,12 \\
\mu \mathrm{g} / \mathrm{mL}\end{array}$ & $1,6 \mu \mathrm{g} / \mathrm{mL}$ \\
\hline B & $1 \mathrm{mg} / \mathrm{mL}$ & $0,8 \mathrm{mg} / \mathrm{mL}$ & $0,6 \mathrm{mg} / \mathrm{mL}$ & $0,4 \mathrm{mg} / \mathrm{mL}$ & $200 \mu \mathrm{g} / \mathrm{mL}$ & $100 \mu \mathrm{g} / \mathrm{mL}$ & $50 \mu \mathrm{g} / \mathrm{mL}$ & $25 \mu \mathrm{g} / \mathrm{mL}$ & $\begin{array}{c}12,5 \\
\mu \mathrm{g} / \mathrm{mL}\end{array}$ & $\begin{array}{c}6,25 \\
\mu \mathrm{g} / \mathrm{mL}\end{array}$ & $\begin{array}{c}3,12 \\
\mu \mathrm{g} / \mathrm{mL}\end{array}$ & $1,6 \mu \mathrm{g} / \mathrm{mL}$ \\
\hline c & $1 \mathrm{mg} / \mathrm{mL}$ & $0,8 \mathrm{mg} / \mathrm{mL}$ & $0,6 \mathrm{mg} / \mathrm{mL}$ & $0,4 \mathrm{mg} / \mathrm{mL}$ & $200 \mu \mathrm{g} / \mathrm{mL}$ & $100 \mu \mathrm{g} / \mathrm{mL}$ & $50 \mu \mathrm{g} / \mathrm{mL}$ & $25 \mu \mathrm{g} / \mathrm{mL}$ & $\begin{array}{c}12,5 \\
\mu \mathrm{g} / \mathrm{mL}\end{array}$ & $\begin{array}{c}6,25 \\
\mu \mathrm{g} / \mathrm{mL}\end{array}$ & $\begin{array}{c}3,12 \\
\mu \mathrm{g} / \mathrm{mL}\end{array}$ & $1,6 \mu \mathrm{g} / \mathrm{mL}$ \\
\hline D & & & & & & & & & & & & \\
\hline E & & & & & & & & & & & & \\
\hline $\mathbf{F}$ & & & & & & & & & & & & \\
\hline G & $\begin{array}{c}\text { Controle } \\
\text { positivo }\end{array}$ & $\begin{array}{c}\text { Controle } \\
\text { positivo }\end{array}$ & $\begin{array}{l}\text { Controle } \\
\text { positive }\end{array}$ & $\begin{array}{l}\text { Controle } \\
\text { positivo }\end{array}$ & $\begin{array}{l}\text { Controle } \\
\text { positivo }\end{array}$ & $\begin{array}{l}\text { Controle } \\
\text { positivo }\end{array}$ & $\begin{array}{l}\text { Controle } \\
\text { positivo }\end{array}$ & $\begin{array}{c}\text { Controle } \\
\text { positivo }\end{array}$ & $\begin{array}{l}\text { Controle } \\
\text { positivo }\end{array}$ & $\begin{array}{l}\text { Controle } \\
\text { positivo }\end{array}$ & $\begin{array}{l}\text { Controle } \\
\text { positivo }\end{array}$ & $\begin{array}{c}\text { Controle } \\
\text { positivo }\end{array}$ \\
\hline H & $\begin{array}{l}\text { Controle } \\
\text { esterilidade }\end{array}$ & $\begin{array}{c}\text { Controle } \\
\text { esterilidade }\end{array}$ & $\begin{array}{l}\text { Controle } \\
\text { esterilidade }\end{array}$ & $\begin{array}{c}\text { Controle } \\
\text { esterilidade }\end{array}$ & $\begin{array}{l}\text { Controle } \\
\text { esterilidade }\end{array}$ & $\begin{array}{l}\text { Controle } \\
\text { esterilidade }\end{array}$ & $\begin{array}{l}\text { Controle } \\
\text { esterilidade }\end{array}$ & $\begin{array}{c}\text { Controle } \\
\text { esterilidade }\end{array}$ & $\begin{array}{l}\text { Controle } \\
\text { esterilidade }\end{array}$ & $\begin{array}{c}\text { Controle } \\
\text { esterilidade }\end{array}$ & $\begin{array}{l}\text { Controle } \\
\text { esterilidade }\end{array}$ & $\begin{array}{c}\text { Controle } \\
\text { esterilidade }\end{array}$ \\
\hline
\end{tabular}

A CIM do óleo-resina da copaíba verificada para a bactéria $E$. faecalis foi igual a $1100 \mu \mathrm{g} / \mathrm{mL}$ (Figura 36; Quadro 6). As concentrações do óleo-resina variaram entre $2,0 \mathrm{mg} / \mathrm{mL}$ a $6,25 \mu \mathrm{g} / \mathrm{mL}(\mathrm{v} / \mathrm{v})$ e a partir de $1000 \mathrm{\mu g} / \mathrm{mL}$ o microrganismo $E$. faecalis não apresentou sensibilidade ao óleo-resina.

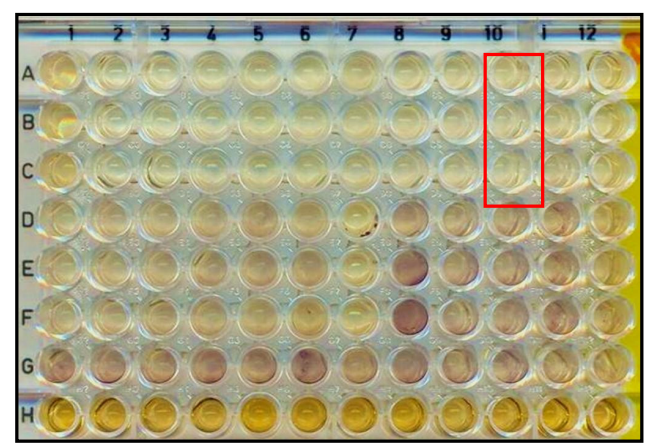

Figura 36 - Imagem digitalizada da microplaca de cultura para a determinação da CIM para o microrganismo E. faecalis. Valor da CIM igual a $1,1 \mathrm{mg} / \mathrm{mL}$. 
Quadro 6 - Representação do protocolo experimental para a determinação da CIM, referente à figura 36.

\begin{tabular}{|c|c|c|c|c|c|c|c|c|c|c|c|c|}
\hline & 1 & 2 & 3 & 4 & 5 & 6 & 7 & 8 & 9 & 10 & 11 & 12 \\
\hline A & $2,0 \mathrm{mg} / \mathrm{mL}$ & $1,9 \mathrm{mg} / \mathrm{mL}$ & $1,8 \mathrm{mg} / \mathrm{mL}$ & $1,7 \mathrm{mg} / \mathrm{mL}$ & $1,6 \mathrm{mg} / \mathrm{mL}$ & $1,5 \mathrm{mg} / \mathrm{mL}$ & $1,4 \mathrm{mg} / \mathrm{mL}$ & $1,3 \mathrm{mg} / \mathrm{mL}$ & $1,2 \mathrm{mg} / \mathrm{mL}$ & $1,1 \mathrm{mg} / \mathrm{mL}$ & $1,0 \mathrm{mg} / \mathrm{mL}$ & $900 \mu \mathrm{g} / \mathrm{mL}$ \\
\hline B & $2,0 \mathrm{mg} / \mathrm{mL}$ & $1,9 \mathrm{mg} / \mathrm{mL}$ & $1,8 \mathrm{mg} / \mathrm{mL}$ & $1,7 \mathrm{mg} / \mathrm{mL}$ & $1,6 \mathrm{mg} / \mathrm{mL}$ & $1,5 \mathrm{mg} / \mathrm{mL}$ & $1,4 \mathrm{mg} / \mathrm{mL}$ & $1,3 \mathrm{mg} / \mathrm{mL}$ & $1,2 \mathrm{mg} / \mathrm{mL}$ & $1,1 \mathrm{mg} / \mathrm{mL}$ & $1,0 \mathrm{mg} / \mathrm{mL}$ & $900 \mu \mathrm{g} / \mathrm{mL}$ \\
\hline C & $2,0 \mathrm{mg} / \mathrm{mL}$ & $1,9 \mathrm{mg} / \mathrm{mL}$ & $1,8 \mathrm{mg} / \mathrm{mL}$ & $1,7 \mathrm{mg} / \mathrm{mL}$ & $1,6 \mathrm{mg} / \mathrm{mL}$ & $1,5 \mathrm{mg} / \mathrm{mL}$ & $1,4 \mathrm{mg} / \mathrm{mL}$ & $1,3 \mathrm{mg} / \mathrm{mL}$ & $1,2 \mathrm{mg} / \mathrm{mL}$ & $1,1 \mathrm{mg} / \mathrm{mL}$ & $1,0 \mathrm{mg} / \mathrm{mL}$ & $900 \mu \mathrm{g} / \mathrm{mL}$ \\
\hline D & $800 \mu \mathrm{g} / \mathrm{mL}$ & $700 \mu \mathrm{g} / \mathrm{mL}$ & $600 \mu \mathrm{g} / \mathrm{mL}$ & $500 \mu \mathrm{g} / \mathrm{mL}$ & $400 \mu \mathrm{g} / \mathrm{mL}$ & $300 \mu \mathrm{g} / \mathrm{mL}$ & $200 \mu \mathrm{g} / \mathrm{mL}$ & $100 \mu \mathrm{g} / \mathrm{mL}$ & $50 \mu \mathrm{g} / \mathrm{mL}$ & $25 \mu \mathrm{g} / \mathrm{mL}$ & $12,5 \mu \mathrm{g} / \mathrm{mL}$ & $\begin{array}{c}6,25 \\
\mu \mathrm{g} / \mathrm{mL}\end{array}$ \\
\hline E & $800 \mu \mathrm{g} / \mathrm{mL}$ & $700 \mu \mathrm{g} / \mathrm{mL}$ & $600 \mu \mathrm{g} / \mathrm{mL}$ & $500 \mu \mathrm{g} / \mathrm{mL}$ & $400 \mu \mathrm{g} / \mathrm{mL}$ & $300 \mu \mathrm{g} / \mathrm{mL}$ & $200 \mu \mathrm{g} / \mathrm{mL}$ & $100 \mu \mathrm{g} / \mathrm{mL}$ & $50 \mu \mathrm{g} / \mathrm{mL}$ & $25 \mu \mathrm{g} / \mathrm{mL}$ & $12,5 \mu \mathrm{g} / \mathrm{mL}$ & $\begin{array}{c}6,25 \\
\mu \mathrm{g} / \mathrm{mL}\end{array}$ \\
\hline $\mathbf{F}$ & $800 \mu \mathrm{g} / \mathrm{mL}$ & $700 \mu \mathrm{g} / \mathrm{mL}$ & $600 \mu \mathrm{g} / \mathrm{mL}$ & $500 \mu \mathrm{g} / \mathrm{mL}$ & $400 \mu \mathrm{g} / \mathrm{mL}$ & $300 \mu \mathrm{g} / \mathrm{mL}$ & $200 \mu \mathrm{g} / \mathrm{mL}$ & $100 \mu \mathrm{g} / \mathrm{mL}$ & $50 \mu \mathrm{g} / \mathrm{mL}$ & $25 \mu \mathrm{g} / \mathrm{mL}$ & $12,5 \mu \mathrm{g} / \mathrm{mL}$ & $\begin{array}{c}6,25 \\
\mu \mathrm{g} / \mathrm{mL}\end{array}$ \\
\hline G & $\begin{array}{l}\text { Controle } \\
\text { positivo }\end{array}$ & $\begin{array}{l}\text { Controle } \\
\text { positivo }\end{array}$ & $\begin{array}{l}\text { Controle } \\
\text { positivo }\end{array}$ & $\begin{array}{l}\text { Controle } \\
\text { positivo }\end{array}$ & $\begin{array}{l}\text { Controle } \\
\text { positivo }\end{array}$ & $\begin{array}{l}\text { Controle } \\
\text { positivo }\end{array}$ & $\begin{array}{l}\text { Controle } \\
\text { positivo }\end{array}$ & $\begin{array}{l}\text { Controle } \\
\text { positivo }\end{array}$ & $\begin{array}{l}\text { Controle } \\
\text { positivo }\end{array}$ & $\begin{array}{l}\text { Controle } \\
\text { positivo }\end{array}$ & $\begin{array}{l}\text { Controle } \\
\text { positivo }\end{array}$ & $\begin{array}{l}\text { Controle } \\
\text { positivo }\end{array}$ \\
\hline H & $\begin{array}{c}\text { Controle } \\
\text { esterilidade }\end{array}$ & $\begin{array}{c}\text { Controle } \\
\text { esterilidade }\end{array}$ & $\begin{array}{l}\text { Controle } \\
\text { esterilidade }\end{array}$ & $\begin{array}{c}\text { Controle } \\
\text { esterilidade }\end{array}$ & $\begin{array}{c}\text { Controle } \\
\text { esterilidade }\end{array}$ & $\begin{array}{c}\text { Controle } \\
\text { esterilidade }\end{array}$ & $\begin{array}{l}\text { Controle } \\
\text { esterilidade }\end{array}$ & $\begin{array}{l}\text { Controle } \\
\text { esterilidade }\end{array}$ & $\begin{array}{c}\text { Controle } \\
\text { esterilidade }\end{array}$ & $\begin{array}{c}\text { Controle } \\
\text { esterilidade }\end{array}$ & $\begin{array}{c}\text { Controle } \\
\text { esterilidade }\end{array}$ & $\begin{array}{c}\text { Controle } \\
\text { esterilidade }\end{array}$ \\
\hline
\end{tabular}

Para os microrganismos E. coli e $P$. aeruginosa, quatro protocolos com concentrações diferentes de óleo-resina foram testados, entretanto, estes microrganismos foram resistentes. A Figura $\mathbf{3 7}$ representa o perfil de crescimento e resistência (ausência de sensibilidade ao óleo-resina) para estes microrganismos, que foi exatamente igual em todos os protocolos avaliados.

(a)
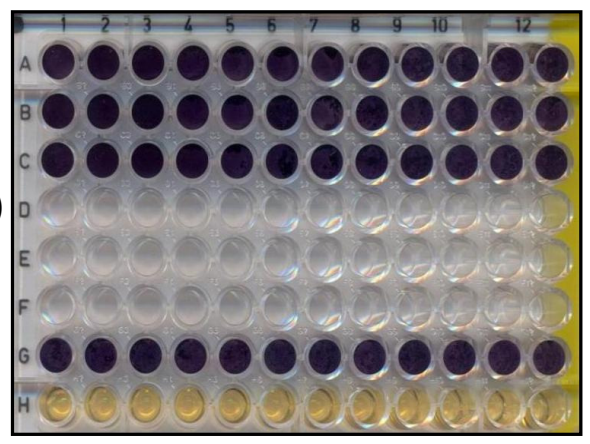

(b)
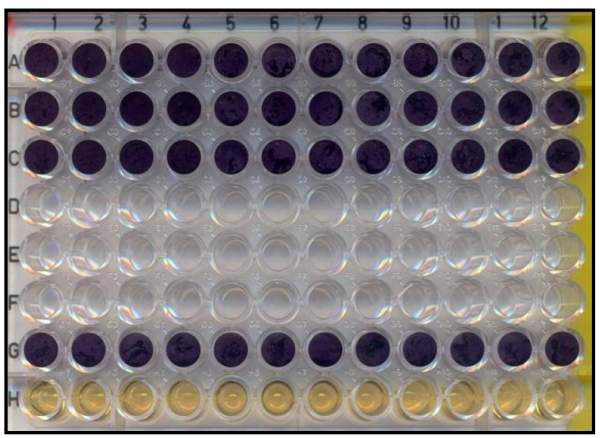

Figura 37 - Imagens digitalizadas das microplacas para a determinação da CIM para os microrganismos $E$. coli (a) e $P$. aeruginosa (b).

\subsubsection{Determinação da Concentração Bactericida Mínima (CBM)}

A determinação da CBM foi realizada apenas para os microrganismos que foram sensíveis ao óleo-resina de copaíba após a determinação da CIM.

Uma alíquota de $250 \mu \mathrm{L}$ da cultura de $S$. aureus da coluna 12 , fileiras A a C e das colunas 1 e 2 , fileiras $D$ a $F$ da microplaca onde não se observou 
crescimento foi semeada em placa de Petri contendo ágar $\mathrm{MH}$. Após incubação a $37^{\circ} \mathrm{C}$ durante 48 horas, não se observou crescimento bacteriano nas três concentrações do óleo-resina avaliadas. Desta forma, sob as condições estudadas, a concentração que inibiu o crescimento bacteriano (CIM) também foi a concentração bactericida mínima para o $S$. aureus (Figura 38). Pode-se sugerir que $200 \mu \mathrm{g} / \mathrm{mL}$ do óleo-resina apresentou atividades bacteriostática e bactericida para o S. aureus.
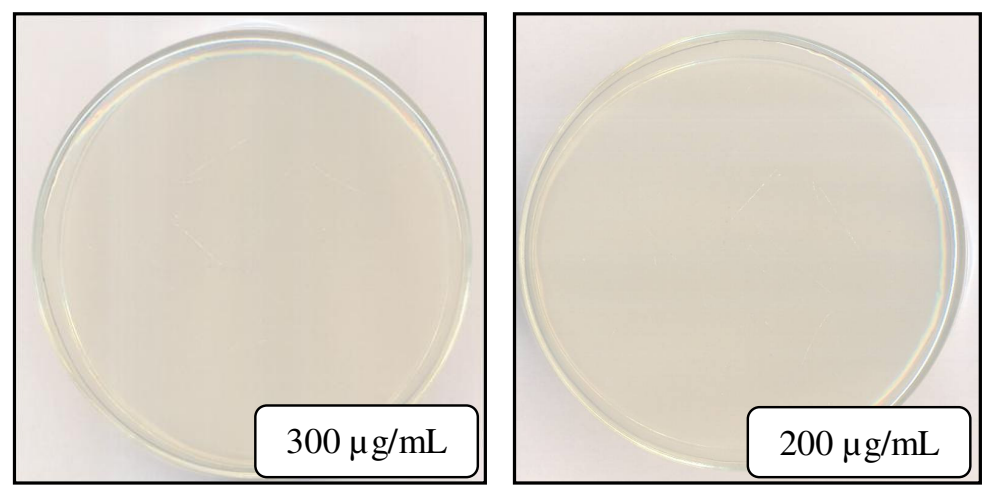

Figura 38 - Imagens digitalizadas das placas de cultura de $S$. aureus para a determinação da CBM. Valor da CBM igual a $200 \mu \mathrm{g} / \mathrm{mL}$.

Uma alíquota de $250 \mu \mathrm{L}$ da cultura de $S$. pyogenes das colunas 1 a 4, fileiras A a C da microplaca onde não observou-se crescimento foi semeada em placa de Petri contendo ágar BHI. Após incubação, se observou: crescimento de 1 colônia nas três placas correspondentes à coluna 1 , fileiras $A$ a $C$, que correspondem à concentração de $1,0 \mathrm{mg} / \mathrm{mL}$ do óleo-resina; crescimento de 1 colônia nas três placas correspondentes à coluna 2, fileiras A a C, que correspondem a $800 \mu \mathrm{g} / \mathrm{mL}$; crescimento de 2 colônias nas três placas correspondentes à coluna 3, fileiras A a C, que correspondem a $600 \mu \mathrm{g} / \mathrm{mL}$. Não houve crescimento bacteriano nas placas correspondentes aos poços da coluna 4 , fileiras A a C, que correspondem a $400 \mu \mathrm{g} / \mathrm{mL}$ do óleo-resina, sugerindo que esta concentração seja bactericida para este microrganismo. Desta forma, o óleoresina de copaíba, sob as condições estudadas, na concentração de $400 \mu \mathrm{g} / \mathrm{mL}$ foi bacteriostático e bactericida para o microrganismo S. pyogenes (Figura 39). 

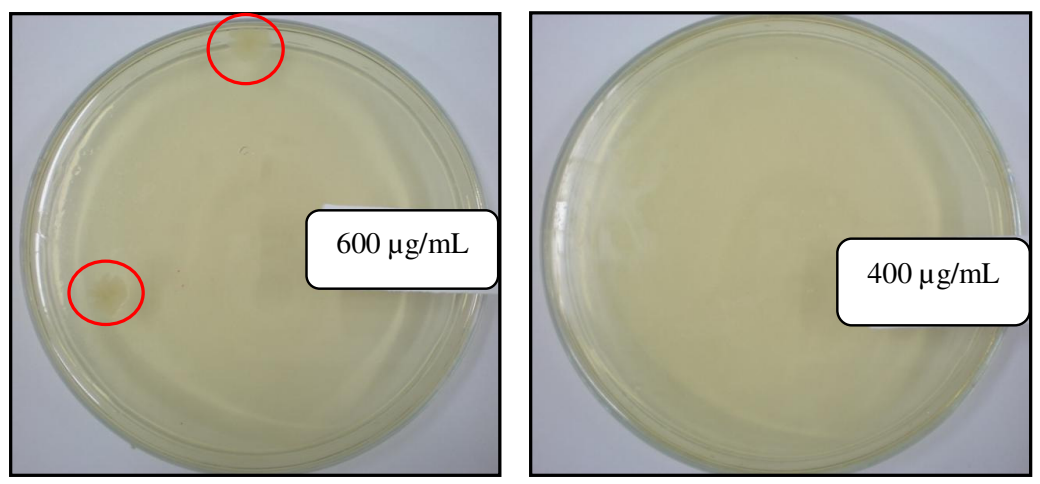

Figura 39 - Imagens digitalizadas das placas de cultura de $S$. pyogenes para a determinação da CBM. Valor da CBM igual a $400 \mu \mathrm{g} / \mathrm{mL}$.

Uma alíquota de $250 \mu \mathrm{L}$ da cultura de E. faecalis das colunas 8 a 10, fileiras A a C da microplaca onde não se observou crescimento foi semeada, em placa de Petri contendo ágar BHI. Após incubação, nas placas correspondentes aos poços da coluna 8, fileiras A a C, que correspondem à concentração de 1,3 $\mathrm{mg} / \mathrm{mL}$ do óleo-resina, se observou crescimento de 2 colônias nas três placas; nas placas correspondentes aos poços da coluna 9, fileiras A a C, que correspondem à concentração de $1,2 \mathrm{mg} / \mathrm{mL}$ do óleo-resina, não se observou crescimento nas três placas; nas placas correspondentes aos poços da coluna 10, fileiras $\mathrm{A}$ a $\mathrm{C}$, que correspondem à concentração de $1,1 \mathrm{mg} / \mathrm{mL}$ do óleo-resina, observou-se crescimento de 1 colônia em cada uma das três placas. Desta forma, sob as condições estudas, na concentração inibitória mínima de 1,1 $\mathrm{mg} / \mathrm{mL}$, o óleo-resina apresenta efeito bacteriostático para $E$. faecalis e, na concentração de $1,2 \mathrm{mg} / \mathrm{mL}$, bactericida, uma vez que não se observou crescimento bacteriano nesta concentração (Figura 40).
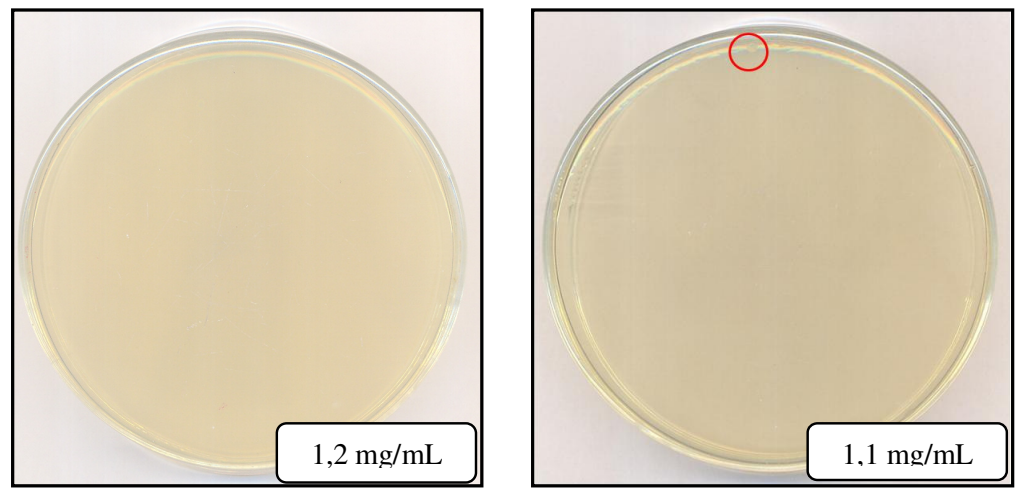

Figura 40 - Imagens digitalizadas das placas de cultura de E. faecalis para a determinação da CBM. Valor da CBM igual a $1,2 \mathrm{mg} / \mathrm{mL}$. 


\subsection{ESTUDO 6: Avaliação da atividade antimicrobiana in vivo do óleo- resina de copaíba em úlceras cutâneas infectadas em ratos}

Previamente ao preparo das suspensões bacterianas para a inoculação nas úlceras, avaliou-se a viabilidade das cepas adquiridas. Após a realização das culturas, houve crescimento de ambos os microrganismos em todos os meios de cultura estudados. O padrão das colônias estava de acordo com as especificações fornecidas pela empresa ATCC. Para as culturas de S. aureus, observou-se colônias pequenas e amareladas nos meios de cultura TSA e MHa; turvamento no meios BHI e TSB e beta-hemólise nas placas com o meio de cultura TSA suplementado com 5\% de sangue desfibrinado de carneiro (Figura 41 ).
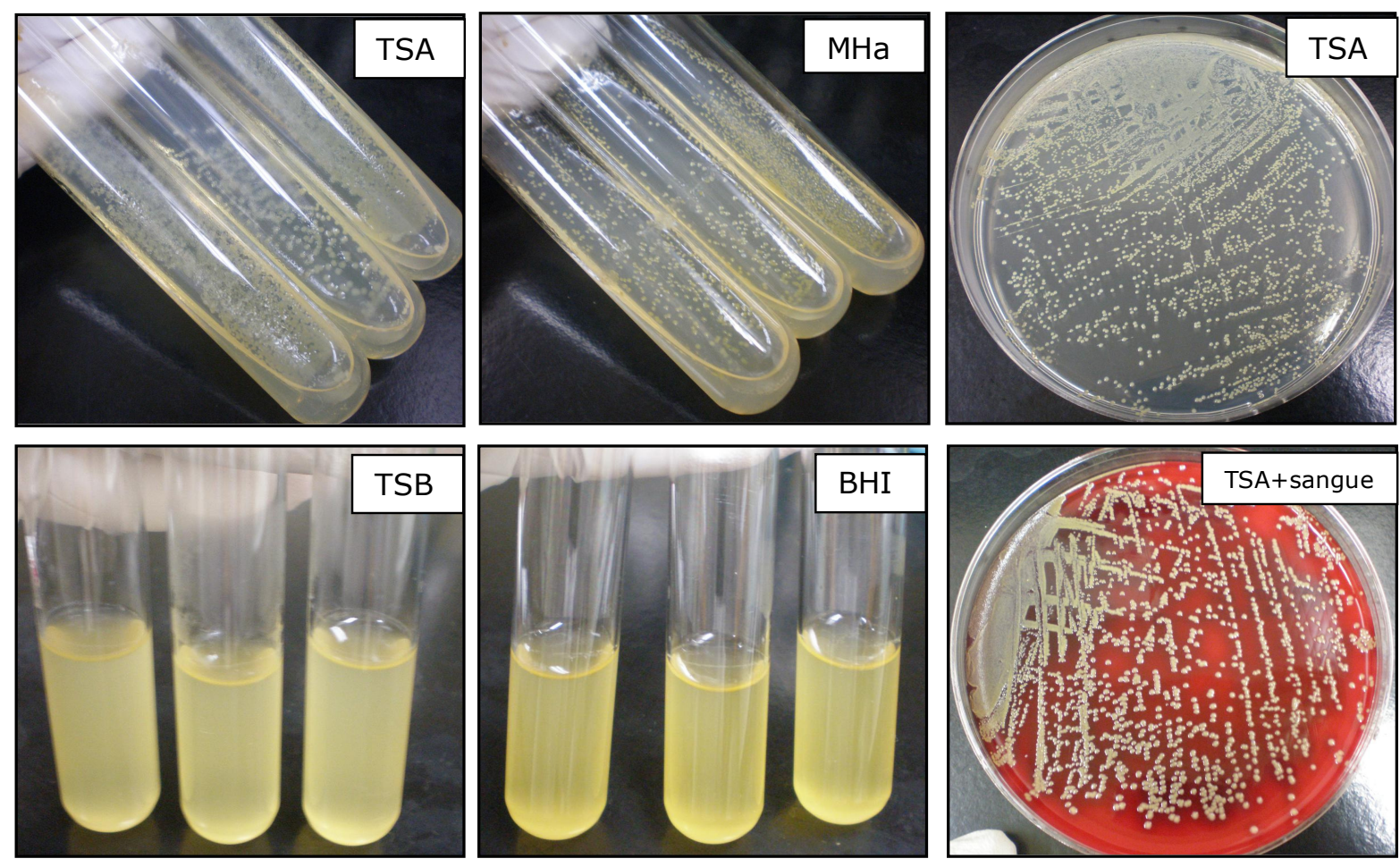

Figura 41 - Representação fotográfica do crescimento e viabilidade do microrganismo S. aureus em diferentes meios de cultura.

Para as culturas de $S$. pyogenes, observou-se o padrão característico de turvação de anaeróbios nos meios de cultura BHI e Tioglicolato sem dextrose ou indicador e colônias circulares que podem ser pequenas ou grandes, cintilantes e 
beta-hemolíticas nas placas com o meio de cultura TSA suplementado com $5 \%$ de sangue desfibrinado de carneiro (Figura 42).
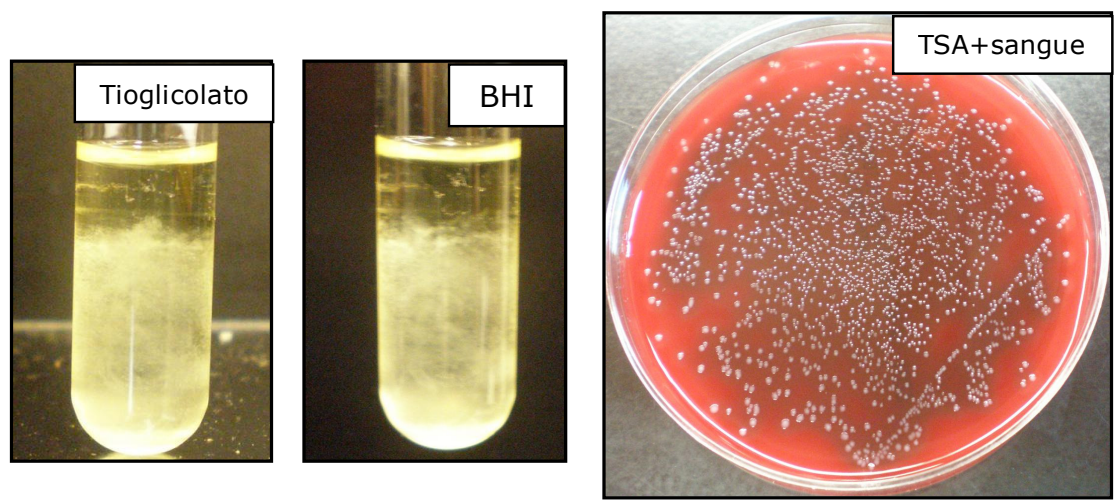

Figura 42 - Representação fotográfica do crescimento e viabilidade do microrganismo $S$. pyogenes em diferentes meios de cultura.

\subsubsection{Avaliação inicial do perfil microbiológico das úlceras}

Para confirmar a presença dos microrganismos inoculados nas úlceras, foram colhidos swabs 24 horas após a inoculação e as culturas microbiológicas foram realizadas a partir do material colhido. Após o processamento das amostras, as mesmas foram diluídas em solução fisiológica estéril nas proporções 1:10, 1:100, 1:1000 e 1:10.000. As diluições, assim como o próprio swab e a solução inicial do mesmo foram inoculadas em placas de cultura contendo o meio TSA suplementado com 5\% de sangue desfibrinado de carneiro.

Todas as amostras avaliadas mostraram crescimento bacteriano. Para a representação fotográfica das placas de cultura, utilizou-se imagens de 1 rato por grupo e a diluição da amostra de 1:10. A diluição das amostras em 1:10 foi utilizada para que as imagens das amostras estivessem na mesma condição, entretanto, para a contagem da densidade bacteriana, ou unidades formadoras de colônia (UFC/mL), todas as diluições, onde era possível observar colônias isoladas, foram utilizadas para obter a média de UFC para cada amostra/animal. A Figura 43 representa colônias com as características dos microrganismos inoculados [S. aureus (a-c); S. pyogenes (d-f)]. As Figuras 43a e 43d representam culturas dos swabs colhidos das úlceras tratadas com solução 
fisiológica; 43b e 43e com creme base e 43c e $43 f$ com creme a 10\% de óleoresina de copaíba.
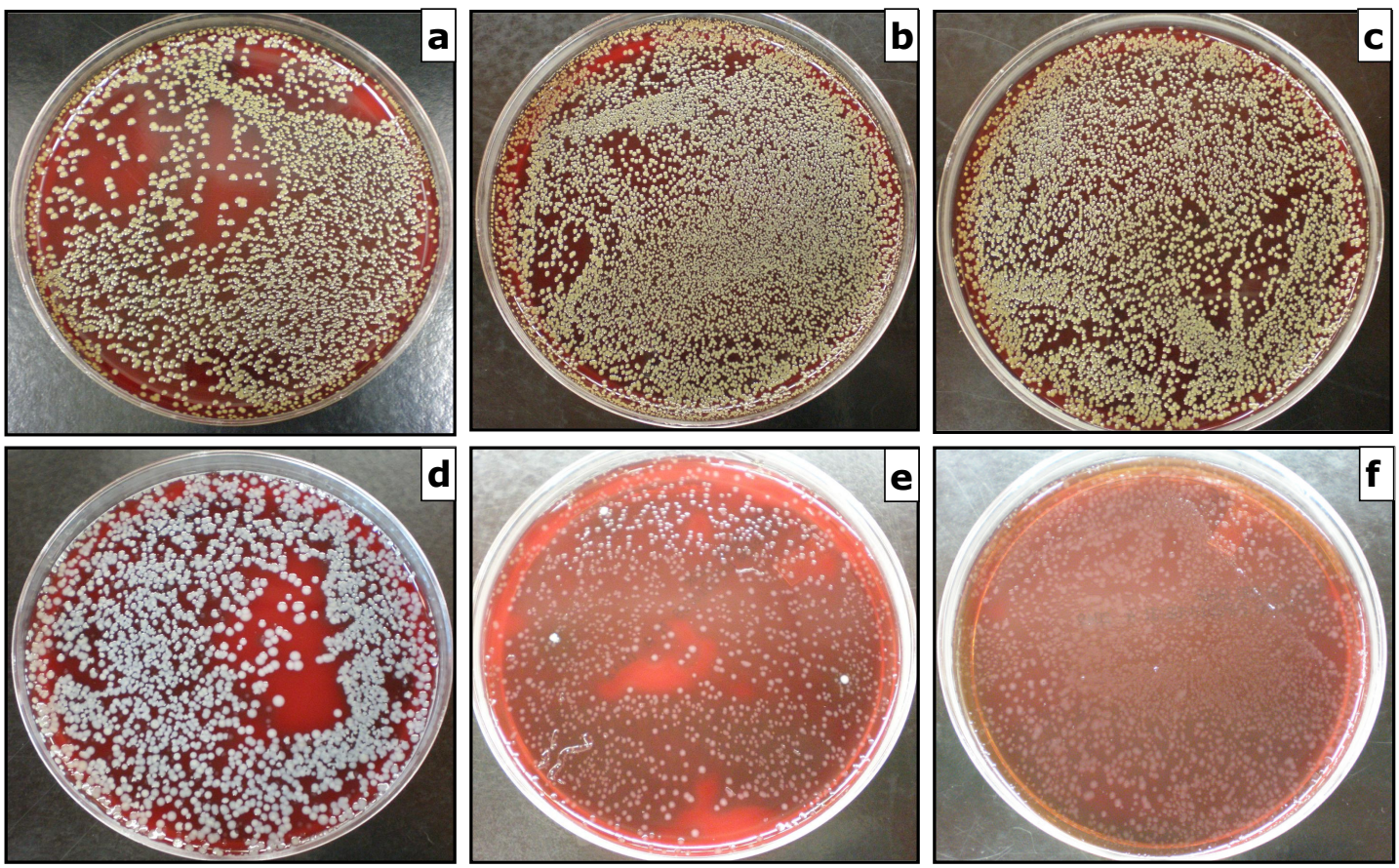

Figura 43 - Representação fotográfica das culturas realizadas a partir de swabs colhidos 24 horas após inoculação bacteriana nas úlceras com $S$. aureus (a-c) e S. pyogenes (df). Diluição das amostras 1:10. Tratamentos aplicados: Solução fisiológica (a, d), Creme base (b, e) e Creme a $10 \%$ de óleo-resina de copaíba $(\mathbf{c}, \mathbf{f})$.

Após incubação, contou-se o número de colônias nas placas onde foi possível observá-las isoladamente. Foram colhidos swabs de três ratos por grupo. Após a leitura das placas, calculou-se o número de microrganismos por placa e posteriormente a média para cada grupo. Níveis considerados indicativos de infecção $\left(10^{5} \mathrm{UFC} / \mathrm{mL}\right.$ ) foram encontrados para todos os grupos de avaliação, conforme demonstrado na Figura 44. Este mesmo procedimento foi realizado durante todo o período de seguimento microbiológico das úlceras, tanto para as culturas realizadas a partir de swabs quanto para aquelas a partir das biópsias. 


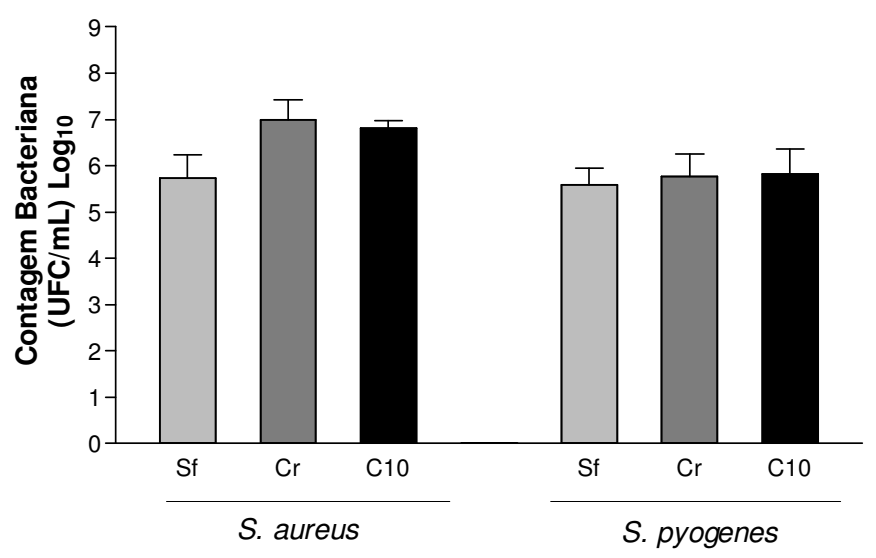

Figura 44 - Contagem bacteriana a partir dos exsudatos colhidos 24 horas após a inoculação bacteriana ( $S$. aureus e $S$. pyogenes) nas úlceras tratadas com Solução fisiológica (Sf), Creme base ( $\mathrm{Cr}$ ) e Creme a $10 \%$ de óleo-resina de copaíba (C10). Os resultados representam a média (escala logarítmica de 10) \pm Desvio-padrão $(n=3)$.

Durante a contagem das UFCs, foi possível observar, contra a luz, a presença de beta-hemólise (Figura 45) em todas as placas (TSA suplementado com $5 \%$ de sangue de carneiro) das culturas das úlceras infectadas tanto com $S$. aureus quanto com S. pyogenes.
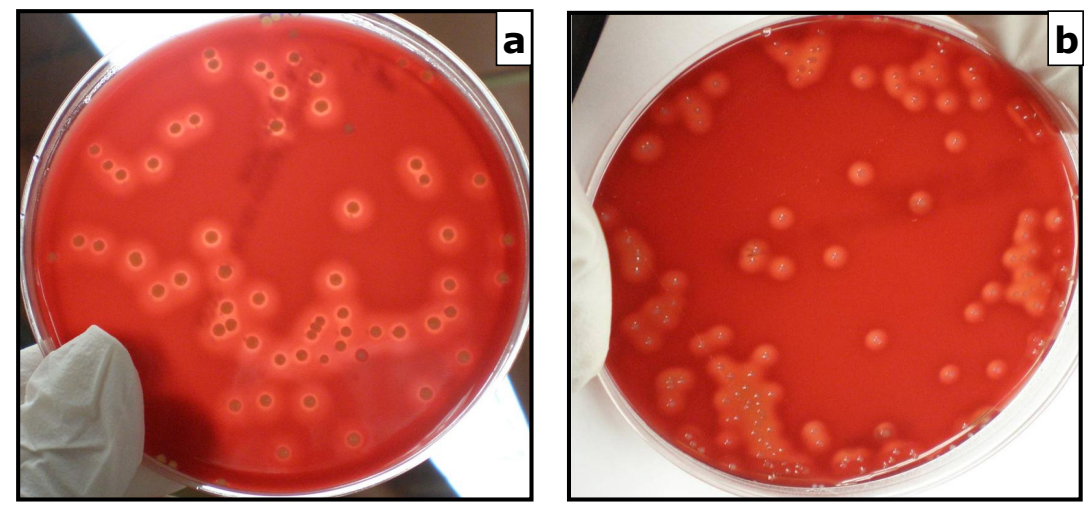

Figura 45 - Representação fotográfica do padrão de beta-hemólise observado nas culturas realizadas a partir de swabs e biópsias das úlceras. S. aureus (a) e S. pyogenes (b). 


\subsubsection{Atividade antimicrobiana in vivo do óleo-resina de copaíba em úlceras cutâneas infectadas com Staphylococcus aureus}

\subsubsection{Seguimento do perfil microbiológico das úlceras pela contagem bacteriana a partir do exsudato (swabs)}

A contagem bacteriana nas culturas realizadas a partir dos exsudatos colhidos das úlceras diminuiu ao final do seguimento (14 dias), exceto para as úlceras tratadas com solução fisiológica, com a contagem ao final semelhante ao início (Figura 46). Para as úlceras tratadas com creme base e creme a $10 \%$ de óleo-resina de copaíba a diminuição do número de colônias foi superior ao grupo solução fisiológica. Embora sem diferença estatisticamente significante, a diminuição da carga bacteriana na superfície de úlceras tratadas com creme a 10\% de óleo-resina pareceu ser clinicamente importante.

A aplicação tópica de creme a $10 \%$ de óleo-resina de copaíba nas úlceras infectadas com $S$. aureus diminuiu o nível total da contagem bacteriana (UFC/mL)

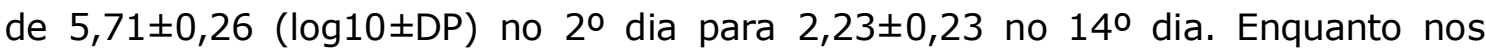
outros grupos foi de $4,52 \pm 0.94$ no 20 dia para $4,70 \pm 0.37$ no 140 dia (solução fisiológica) e $5,79 \pm 0.85$ no $2^{\circ}$ dia para $2,57 \pm 1.05$ no 140 dia (creme base).

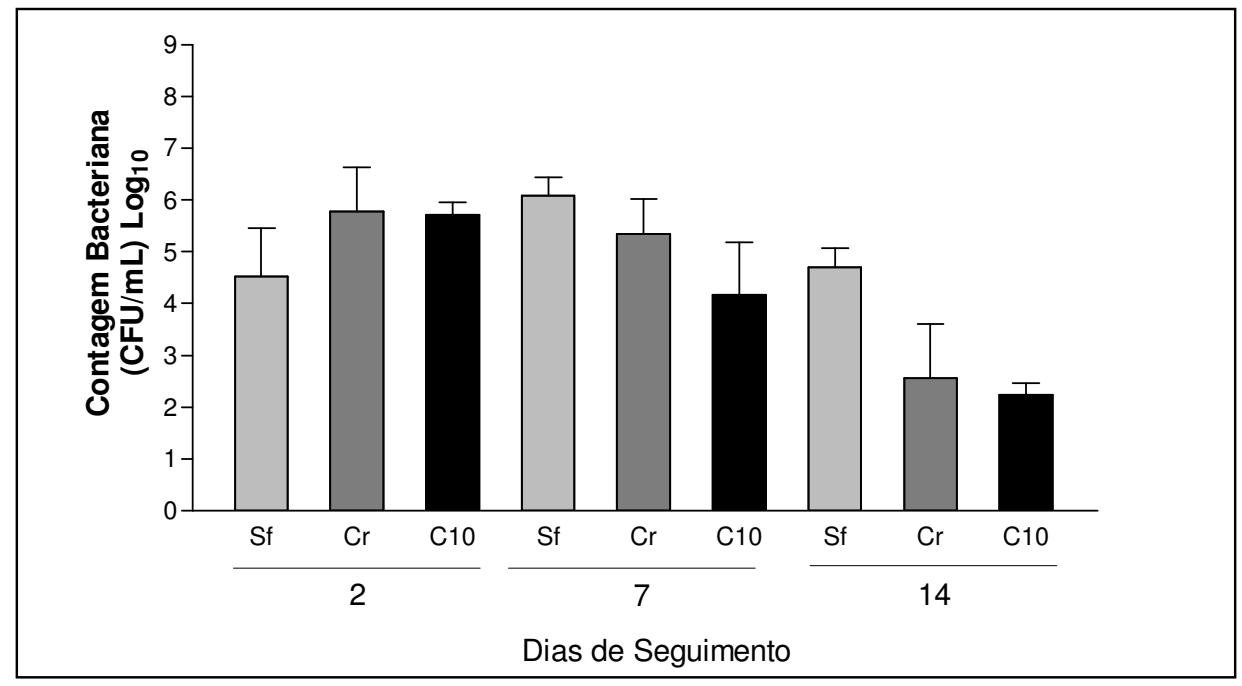

Figura 46 - Contagem bacteriana em culturas realizadas a partir dos exsudatos colhidos durante o seguimento das úlceras infectadas com S. aureus nos dias 2, 7 e 14, conforme os tratamentos: Solução fisiológica (Sf), Creme base (Cr) e Creme a 10\% de óleo-resina de copaíba (C10). Os resultados representam a média (escala logarítmica de 10) \pm Desvio-padrão $(n=3)$. 


\subsubsection{Seguimento do perfil microbiológico das úlceras pela contagem bacteriana a partir do tecido ulcerado (biópsias)}

A contagem bacteriana nas culturas realizadas a partir das biópsias colhidas das úlceras diminuiu em todos os grupos de avaliação ao final do seguimento (Figura 47). A contagem bacteriana nas úlceras tratadas com creme a $10 \%$ de óleo-resina foi menor quando comparada à dos grupos tratados com solução fisiológica e creme base durante todo o seguimento, principalmente no 70 e $14^{\circ}$ dias. No $14^{\circ}$ dia, a contagem bacteriana nas úlceras tratadas solução fisiológica foi superior aos grupos creme base e creme a 10\% de óleo-resina.

A aplicação tópica de creme a $10 \%$ de óleo-resina de copaíba em úlceras infectadas com $S$. aureus diminuiu o nível total da contagem bacteriana (UFC/g tecido) de $7,08 \pm 0,50(\log 10 \pm S D)$ no 20 dia para $5,57 \pm 0,31$ no 140 dia. Enquanto a contagem bacteriana obtida a partir dos grupos controles foi de

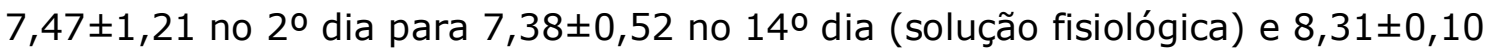
no $2^{\circ}$ dia para $6,88 \pm 0,71$ no $14^{\circ}$ dia (creme base).

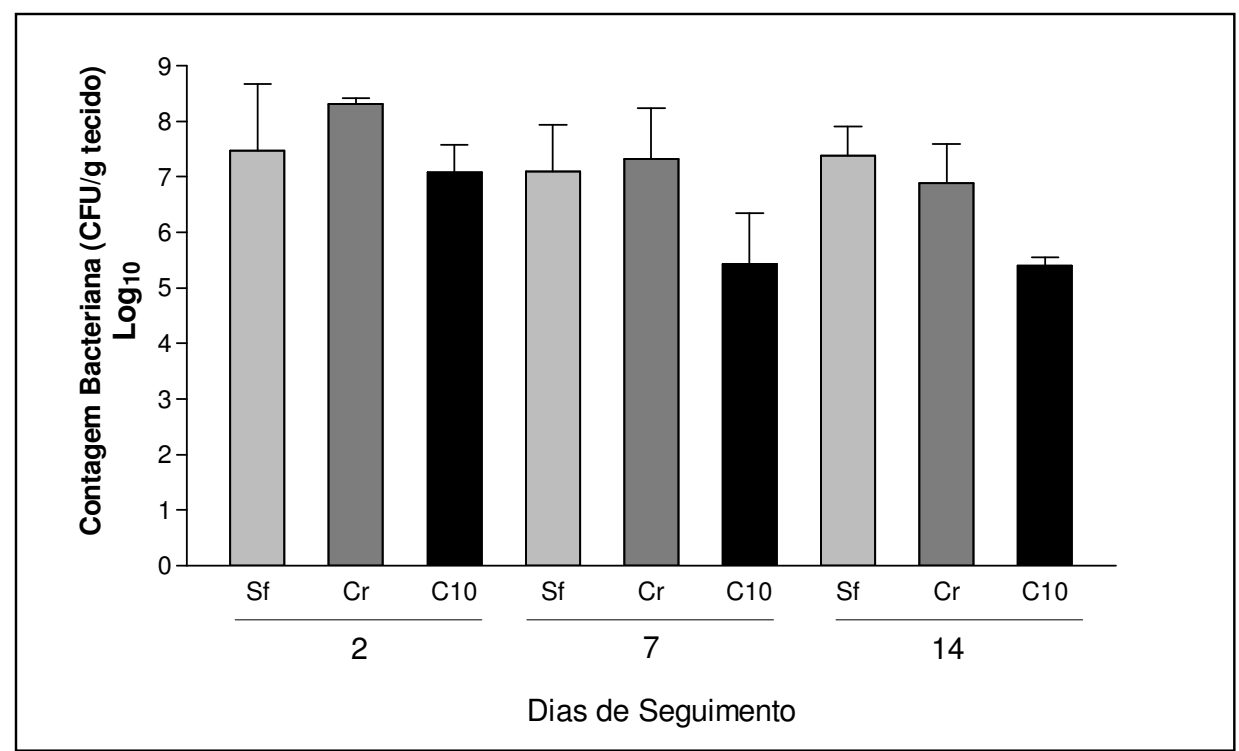

Figura 47 - Contagem bacteriana em culturas realizadas a partir das biópsias colhidas durante o seguimento das úlceras infectadas com $S$. aureus nos dias 2, 7 e 14, conforme os tratamentos: Solução fisiológica (Sf), Creme base controle (Cr) e Creme a 10\% de óleo-resina de copaíba (C10). Os resultados representam a média (escala logarítmica de 10) \pm Desvio-padrão $(n=3)$. (*) Diferenças estatisticamente significantes $(p<0,05)$ 
A Figura 48 representa a característica das colônias e o perfil microbiológico durante o seguimento, ilustrando os resultados da contagem bacteriana apresentados na Figura 47. Para a contagem foram utilizados 3 ratos por dia de avaliação e tratamento e várias diluições, conforme descrito anteriormente, onde foi possível fazer a contagem das colônias. Para a representação fotográfica das placas de cultura, utilizou-se imagens de 1 rato por grupo e a diluição da amostra de 1:100.
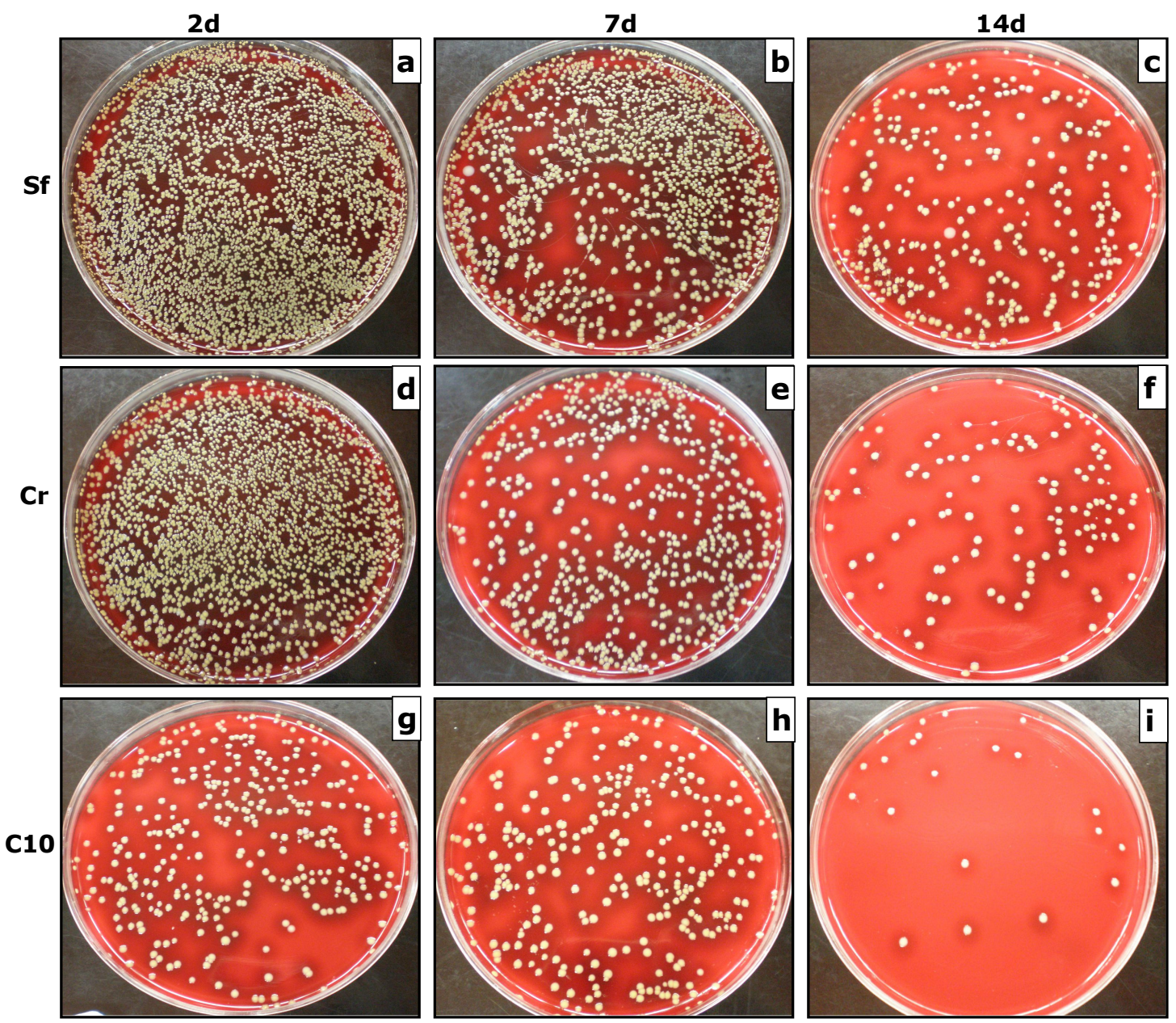

Figura 48 - Seguimento do perfil microbiológico das úlceras. Representação fotográfica das placas de cultura a partir das biópsias colhidas de úlceras infectadas com S. aureus, representando a diluição 1:100 de uma úlcera/rato por dia de avaliação, nos dias 2, 7 e 14, conforme os tratamentos: Solução fisiológica (Sf) (a-c); Creme base (Cr) (d-f); Creme a 10\% de óleo-resina de copaíba (C10) (g-i). 


\subsubsection{Atividade antimicrobiana in vivo do óleo-resina de copaíba em úlceras cutâneas infectadas com Streptococcus pyogenes}

\subsubsection{Seguimento do perfil microbiológico das úlceras pela contagem bacteriana a partir do exsudato (swabs)}

A contagem bacteriana nas culturas realizadas a partir dos exsudatos colhidos das úlceras diminuiu em todos os grupos de avaliação ao final do seguimento (14 dias) (Figura 49). A aplicação tópica do creme a 10\% de óleoresina de copaíba nas úlceras infectadas com $S$. pyogenes diminuiu o nível total

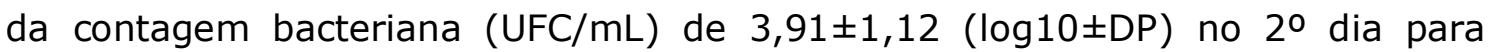
$1,89 \pm 0,16$ no 140 dia. Enquanto nos outros grupos foi de $4,42 \pm 1,20$ no 20 dia

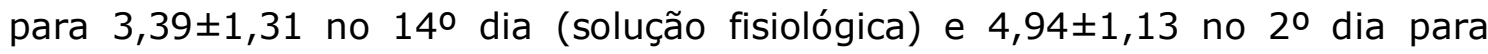
$2,00 \pm 0,0$ no $14^{\circ}$ dia (creme base).

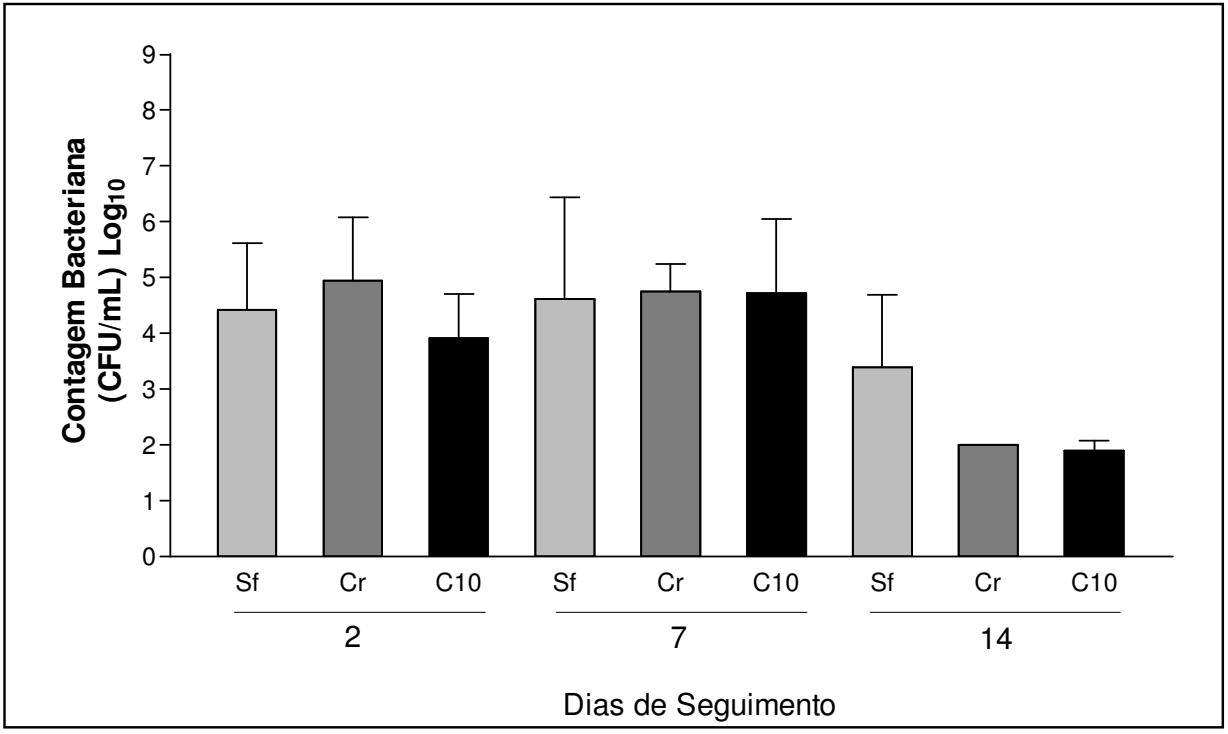

Figura 49 - Contagem bacteriana em culturas realizadas a partir dos exsudatos colhidos durante o seguimento das úlceras infectadas com S. pyogenes nos dias 2, 7 e 14, conforme os tratamentos: Solução fisiológica (Sf), Creme base $(\mathrm{Cr})$ e Creme a $10 \%$ de óleo-resina de copaíba (C10). Os resultados representam a média (escala logarítmica de 10) \pm Desvio-padrão $(n=3)$. 


\subsubsection{Seguimento do perfil microbiológico das úlceras pela contagem bacteriana a partir do tecido ulcerado (biópsias)}

A contagem bacteriana nas culturas realizadas a partir das biópsias colhidas das úlceras diminuiu ao final do seguimento, exceto nas culturas realizadas a partir das úlceras tratadas com creme base (Figura 50). A contagem bacteriana nas úlceras tratadas com creme a $10 \%$ de óleo-resina foi menor quando comparada à contagem para o grupo tratado com solução fisiológica e creme base no $2^{\circ}$ e $14^{\circ}$ dias de seguimento, embora não tenha sido estatisticamente significante pareceu ser clinicamente importante. Quando se comparou o tratamento com creme a $10 \%$ de óleo-resina entre os dias, houve diminuição significativa do número de UFC/g de tecido entre os dias 7 e $14(p<0,05)$.

A aplicação tópica de creme a 10\% de copaíba em úlceras infectadas por S. pyogenes diminuiu o nível total da contagem bacteriana (UFC/g tecido) de $5,53 \pm 1,64(\log 10 \pm D P)$ no $2^{\circ}$ dia para $3,79 \pm 0,15$ no 140 dia. Enquanto a contagem bacteriana obtida a partir dos grupos controles foi de $6,88 \pm 0,85$ no 20

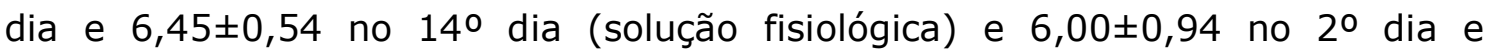
$6,45 \pm 1,93$ no $14^{\circ}$ dia (creme base).

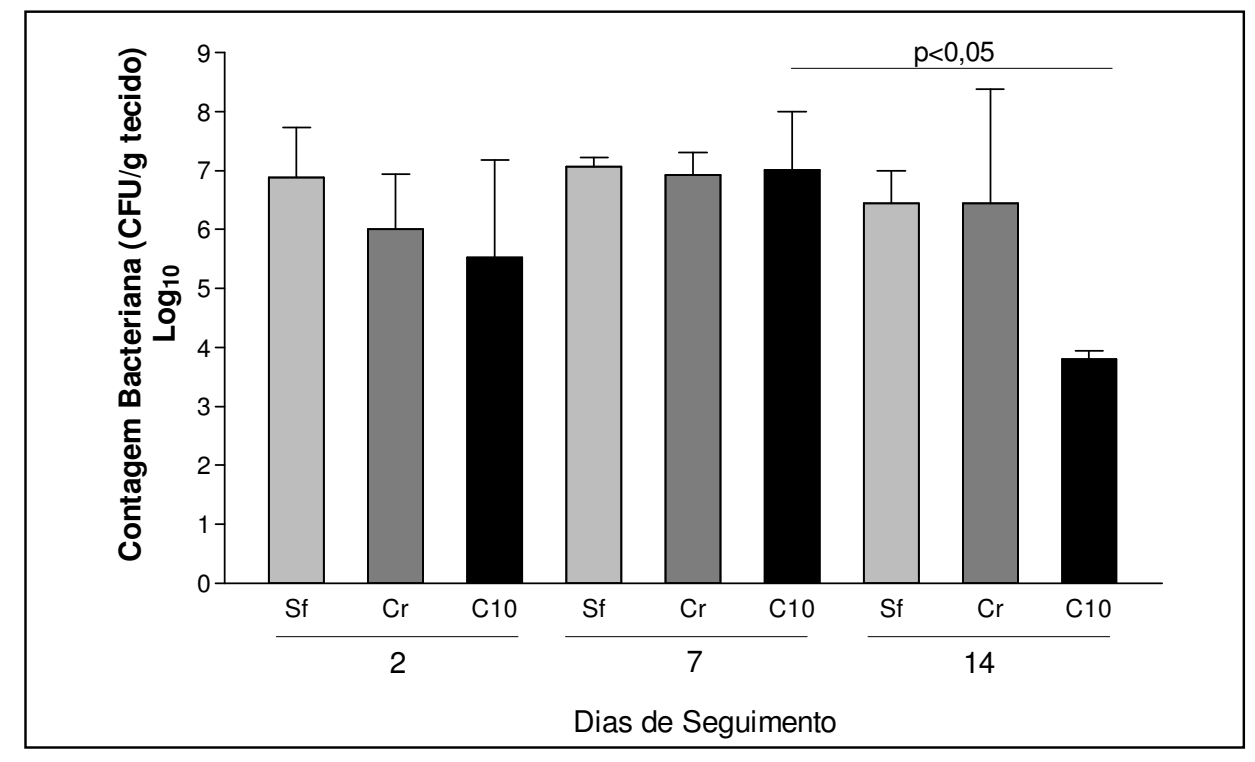

Figura 50 - Contagem bacteriana em culturas realizadas a partir das biópsias colhidas durante o seguimento das úlceras infectadas com S. pyogenes nos dias 2, 7 e 14, conforme os tratamentos: Solução fisiológica (Sf), Creme base (Cr) e Creme a $10 \%$ de óleo-resina de copaíba (C10). Os resultados representam a média (escala logarítmica de 10) \pm Desvio-padrão $(n=3)$. 
A Figura $\mathbf{5 1}$ representa a característica das colônias e o perfil microbiológico durante o seguimento, ilustrando os resultados da contagem bacteriana apresentados na Figura 50. Para a contagem foram utilizados 3 ratos por dia de avaliação e tratamento e várias diluições, conforme descrito anteriormente, onde foi possível fazer a contagem das colônias. Para a representação fotográfica das placas de cultura, utilizou-se imagens de 1 rato por grupo e a diluição da amostra de 1:100.
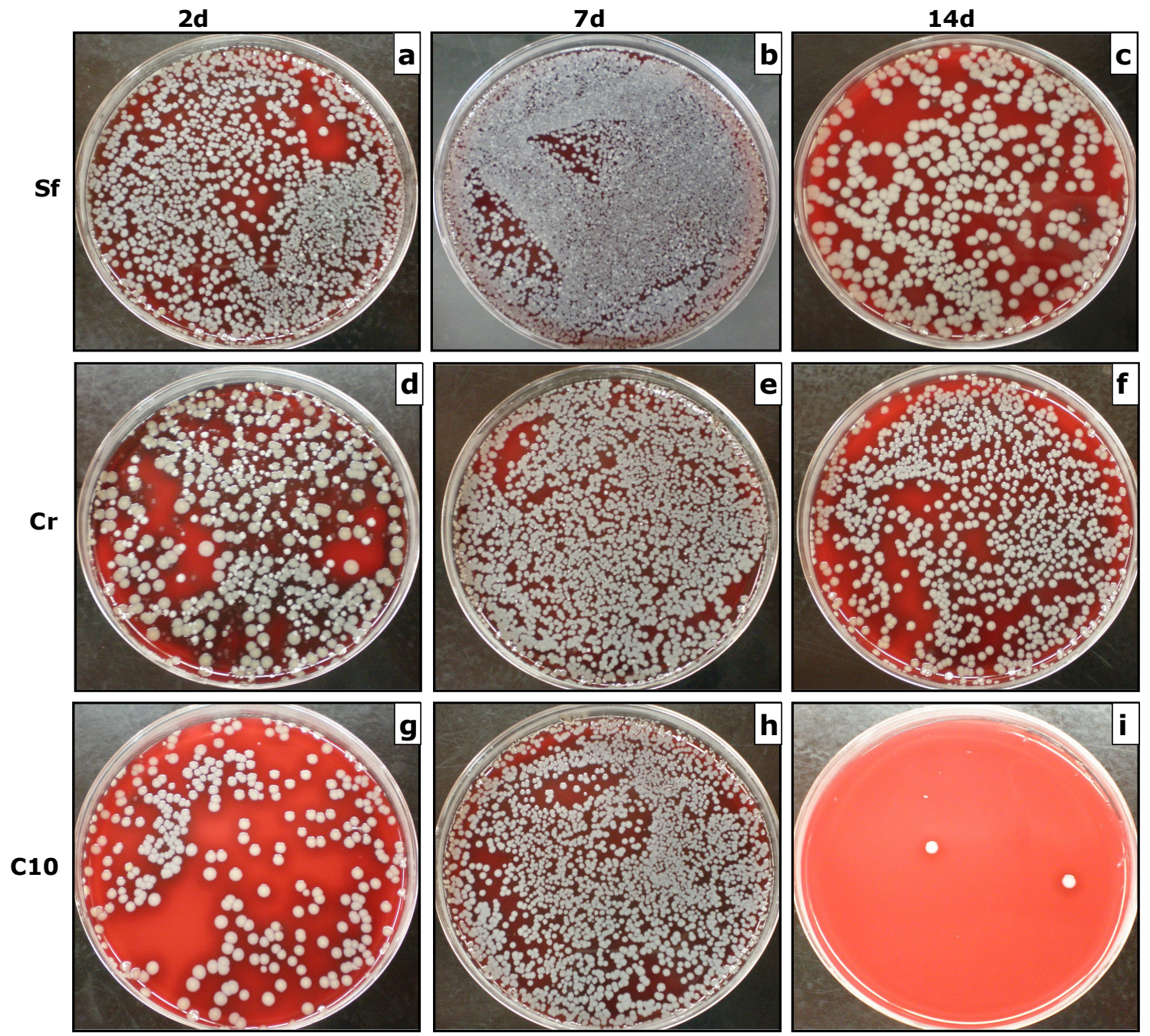

Figura 51 - Seguimento do perfil microbiológico das úlceras. Representação fotográfica das placas de cultura a partir das biópsias colhidas de úlceras infectadas com S. pyogenes, representando a diluição 1:100 de uma úlcera/rato por dia de avaliação, nos dias 2, 7 e 14, conforme os tratamentos: Solução fisiológica (Sf) (a-c); Creme base (Cr) (d-f); Creme a 10\% de óleo-resina de copaíba (C10) (g-i). 


\subsection{ESTUDO 7: Avaliação do potencial cicatrizante do óleo-resina de copaíba em úlceras cutâneas infectadas}

\subsection{1 Úlceras infectadas com $S$. aureus}

\subsubsection{Seguimento clínico-experimental}

A Figura 52 representa o seguimento clínico-fotográfico das úlceras infectadas com S. aureus, com fotos representativas das úlceras de um animal por tratamento e por dia de seguimento. As imagens estão dispostas de acordo com o seguimento nos tempos de 0, 2, 7 e 14 dias. O dia zero representa as úlceras na região dorsal de rato imediatamente após o procedimento cirúrgico, ou seja, sem a inoculação da suspensão bacteriana ou aplicação de qualquer tratamento.

No 20 dia após o procedimento cirúrgico e inoculação da suspensão bacteriana, todas as úlceras apresentavam evidência clínica de infecção local, como exsudato purulento [principalmente as úlceras tratadas com creme base (Figura 52f) e creme a $10 \%$ de óleo-resina de copaíba (Figura 52j] eritema (principalmente as úlceras do grupo solução fisiológica (Figura 52b). A presença de pus foi observada no período de 1 a 4 dias após o procedimento cirúrgico em todos os grupos. As úlceras tratadas com creme base e creme a $10 \%$ de óleoresina encontravam-se mais úmidas que as demais, principalmente durante os 3 primeiros dias de seguimento.

No 70 dia, ainda se evidenciava a presença de eritema, principalmente nas úlceras tratadas com solução fisiológica (Figura 52c) e creme base (Figura $\mathbf{5 2 g}$ ). As áreas ulceradas estavam menores, principalmente no grupo creme a 10\% de óleo-resina (Figura 52j).

No $14^{\circ}$ dia, a maioria das úlceras estava reepitelizada, embora a qualidade do tecido cicatricial nas úlceras tratadas com creme a 10\% de óleoresina de copaíba parecia apresentar uma tendência superior aos demais grupos (Figuras 52d, h, I).

Durante todo o seguimento não foi observado qualquer sinal de infecção sistêmica, visto que os animais mantiveram-se ativos e alimentando-se normalmente. 


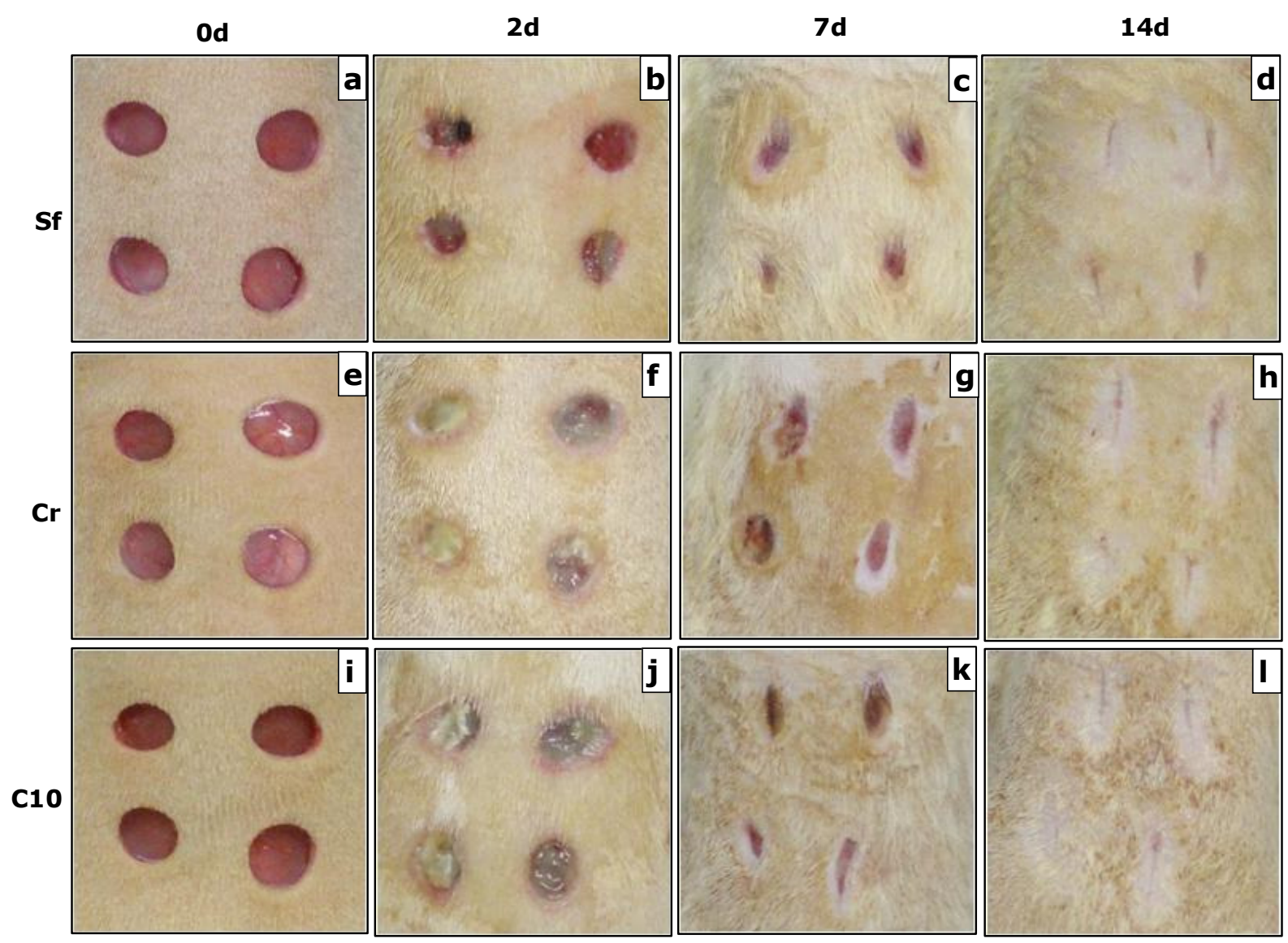

Figura 52 - Seguimento clínico das úlceras infectadas com $S$. aureus nos dias 0, 2, 7 e 14 respectivamente, conforme os tratamentos: Solução fisiológica (Sf) (a-d); Creme base (Cr) (e-h); Creme a 10\% de óleo-resina de copaíba (C10) (i-I).

\subsubsection{2 Índice de Cicatrização das Úlceras (ICU)}

No $2^{\circ}$ dia após o procedimento cirúrgico, os valores de ICU para os grupos tratados com creme base foram inferiores quando comparados aos valores de ICU dos grupos tratados com solução fisiológica $(p<0,05)$ e creme a 10\% de óleo-resina de copaíba (Figura 53).

No 70 dia, os valores de ICU para as úlceras tratadas com creme a $10 \%$ de óleo-resina foram superiores aos demais grupos $(p<0,05)$.

No $14^{\circ}$ dia, a maioria das úlceras estava reepitelizada, com exceção de algumas úlceras tratadas com solução fisiológica (valores de $\mathrm{ICU}=0,90$ ). 


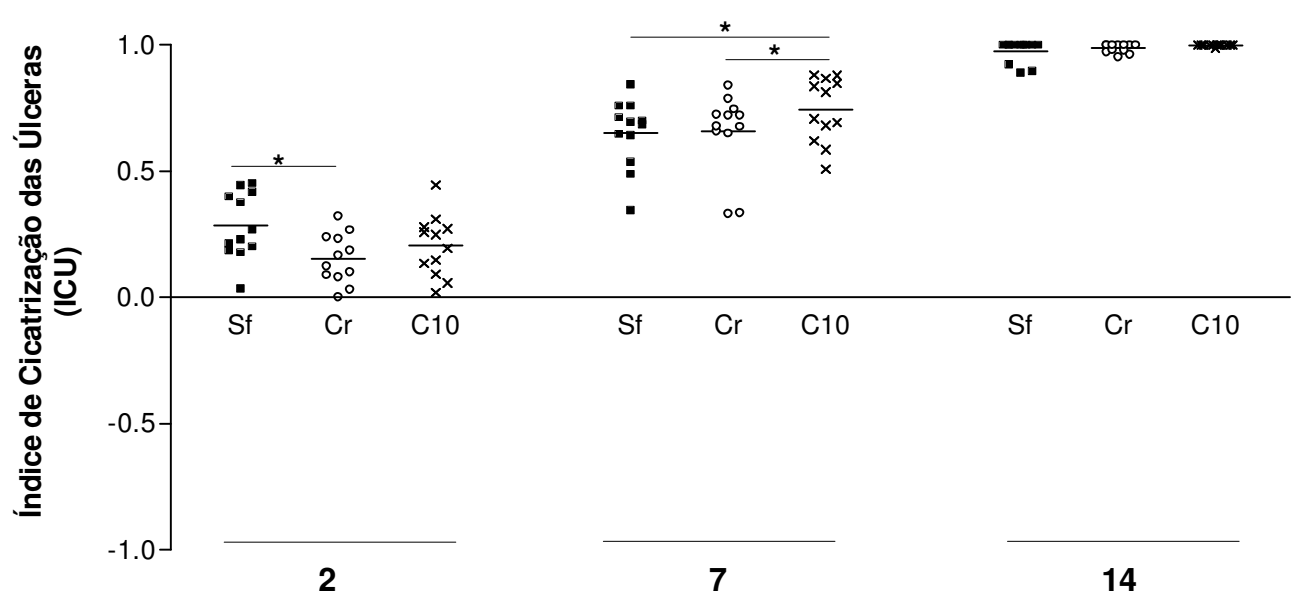

Dias de Seguimento

Figura 53 - Evolução dos índices de cicatrização das úlceras infectadas com S. aureus, nos tempos de avaliação de 2, 7 e 14 dias, conforme os tratamentos: Solução fisiológica (Sf), Creme base (Cr), Creme a $10 \%$ de óleo-resina de copaíba (C10). Os valores representam a média \pm desvio-padrão $(n=12)$. *Diferença estatisticamente significante $(p<0,05)$.

\subsubsection{Avaliação Histopatológica}

A análise qualitativa da celularidade e do infiltrado inflamatório foi realizada pela coloração das lâminas por hematoxilina-eosina. No $2^{\circ}$ dia após o procedimento cirúrgico, observou-se intenso infiltrado inflamatório nas lâminas correspondentes às úlceras tratadas com creme base (Figura 54d) e creme a 10\% de óleo-resina (Figura 54d) e discreto infiltrado inflamatório para o grupo solução fisiológica.

No 70 dia, todos os grupos apresentaram evidência de atividade fibroblástica, observada principalmente nas lâminas correspondentes às úlceras tratadas com creme base (Figura 54e) e creme contendo 10\% de óleo-resina (Figura 54h), enquanto o grupo solução fisiológica (Figura 54b) apresentava importante infiltrado inflamatório (Figura 54c).

No $14^{\circ}$ dia, as lâminas correspondentes às úlceras tratadas solução fisiológica apresentaram mais fibroblastos (Figura 54c) que os grupos creme base (Figura 54f) e creme a 10\% de óleo-resina (Figura 54i).

A análise qualitativa da colagênese também foi realizada pela coloração das lâminas com o tricrômio de Gomori (Figura 55). Em todos os grupos 
avaliados, a intensidade de cor na área da úlcera/tecido cicatricial aumentou gradualmente durante o seguimento, indicando, qualitativamente, aumento da colagênese. Quando foram comparadas as lâminas no $14^{\circ}$ dia, a intensidade de coloração parecia estar discretamente aumentada nas lâminas correspondentes às úlceras tratadas com creme a $10 \%$ de óleo-resina (Figura 55i) comparada aos demais grupos (Figura 55c, f).
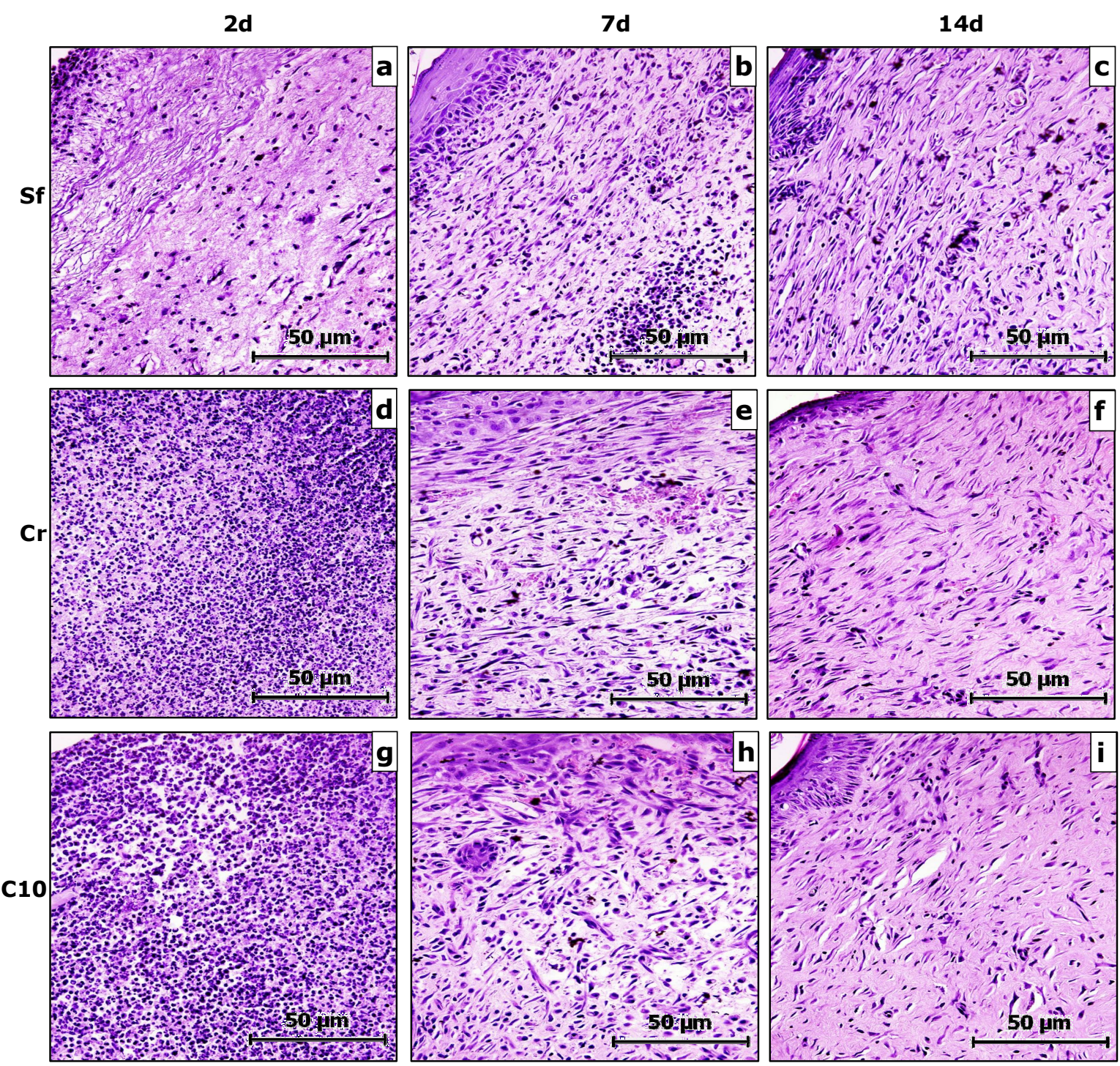

Figura 54 - Avaliação histopatológica das úlceras infectadas com S. aureus nos dias 2, 7 e 14 respectivamente, conforme os tratamentos: Solução fisiológica (Sf) (a-c); Creme base (Cr) (d-f); Creme a 10\% de óleo-resina de copaíba (C10) (g-i). Coloração hematoxilina-eosina. Aumento de 400x. 

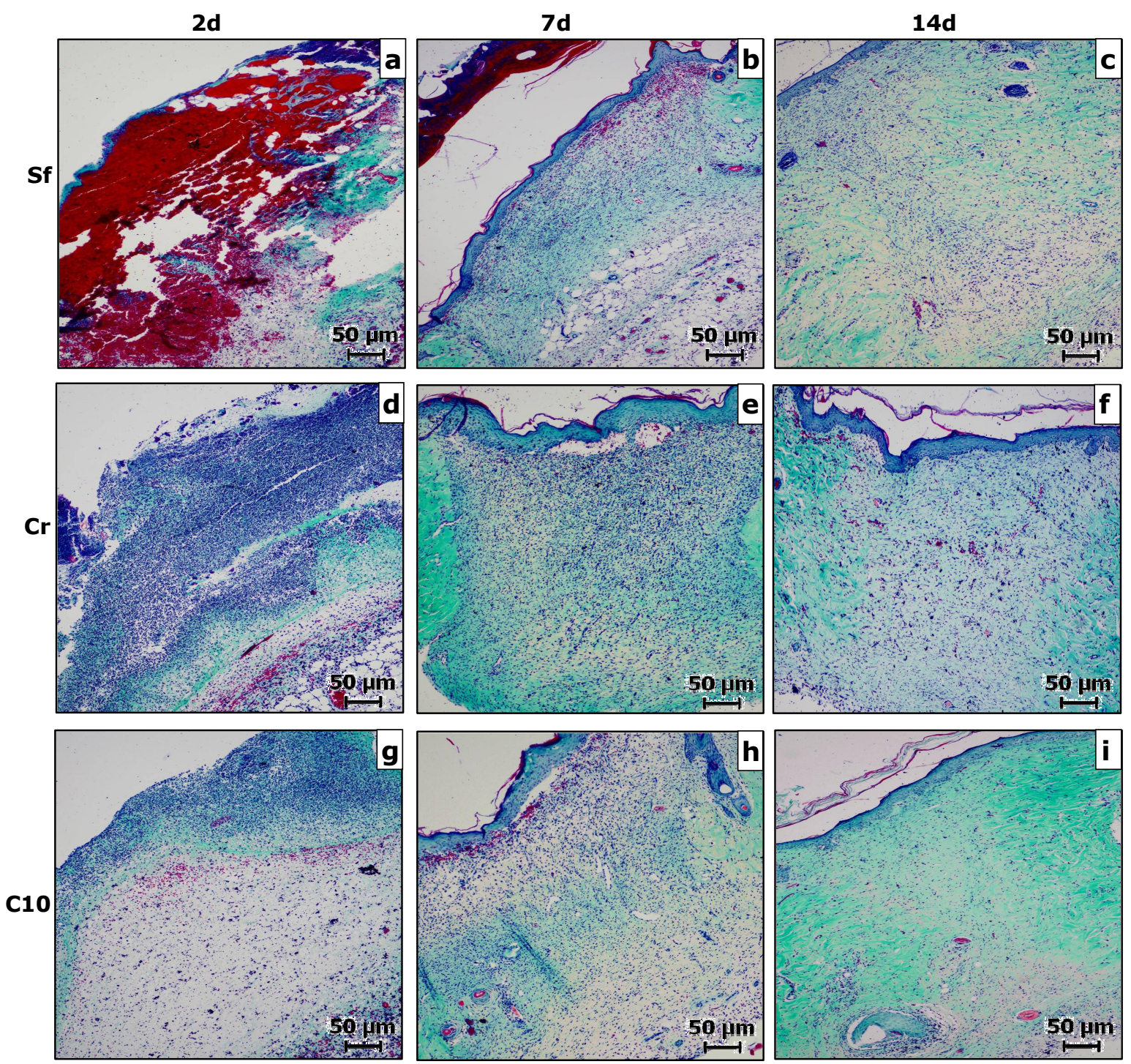

Figura 55 - Avaliação histopatológica das úlceras infectadas com S. aureus, nos dias 2, 7 e 14 respectivamente, conforme os tratamentos: Solução fisiológica (Sf) (a-c); Creme base (Cr) (d-f); Creme a 10\% de óleo-resina de copaíba (C10) (g-i). Coloração tricrômio de Gomori. Aumento de 100x.

\subsubsection{Avaliação Bioquímica: Dosagem de Hidroxiprolina}

Houve aumento progressivo da concentração de hidroxiprolina durante o tempo de seguimento nas úlceras tratadas com solução fisiológica e creme a 10\% de óleo-resina de copaíba, sendo que para as úlceras tratadas com creme base, este aumento foi observado apenas do $2^{\circ}$ para o 70 dia (Figura 56).

Diferenças estatisticamente significantes foram observadas do $2^{\circ}$ para 0 140 dia de seguimento em todos os grupos $(p<0,05: S F ; p<0,01$ : cremes base e 
a $10 \%$ de óleo-resina). Do 20 para o 70 dia, houve diferença estatisticamente significante para as úlceras tratadas com creme $(p<0,001)$ e com creme a $10 \%$ de óleo-resina $(p<0,05)$.

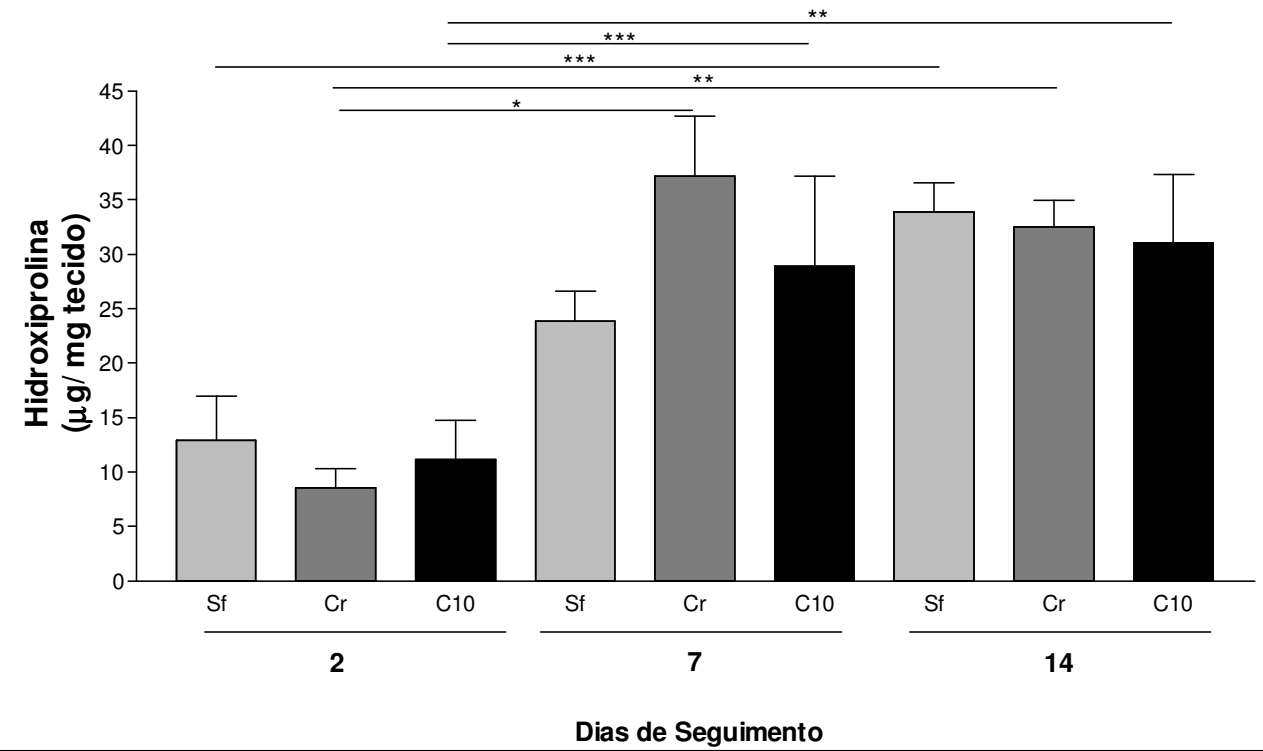

Figura 56 - Concentração de hidroxiprolina durante o seguimento das úlceras infectadas com $S$. aureus nos dias 2, 7 e 14 conforme os tratamentos: Solução fisiológica (Sf), Creme base (Cr) e Creme a $10 \%$ de óleo-resina de copaíba (C10). Os valores representam a média \pm desvio-padrão da análise em triplicata $(n=3)$. Diferenças estatisticamente significantes: $(*) p<0,001 ;(* *) p<0,01$ e $(* * *) \mathrm{p}<0,05$.

\subsubsection{Avaliação Bioquímica: Dosagem de Metaloproteinases}

A Figura 57 representa a imagem digitalizada de um dos géis após a zimografia, demonstrando a presença das metaloproteinases 2 (ativa; pró ou inativa) e 9 , e representadas pelas bandas claras. 


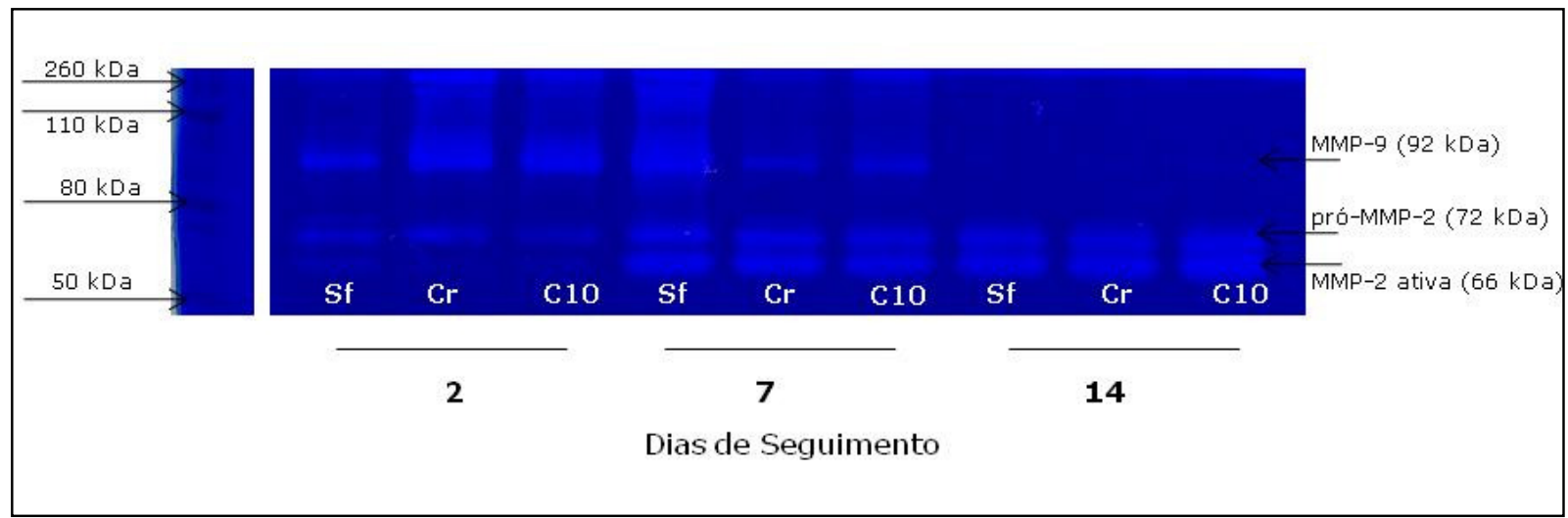

Figura 57 - Imagem digitalizada do gel de zimografia (zimograma) representando a atividade proteolítica das MMPs durante o seguimento das úlceras infectadas com $S$. aureus nos dias 2, 7 e 14, conforme os tratamentos: Solução fisiológica (Sf), Creme base ( $\mathrm{Cr}$ ) e Creme a $10 \%$ de óleo-resina de copaíba (C10). As bandas coradas em azul escuro representam o padrão de peso molecular

Houve aumento da atividade da MMP-2 ativa do $2^{\circ}$ para 070 dia e discreta diminuição do 70 para o $14^{\circ}$ dia de seguimento para todos os grupos (Figura 58a). Diferenças estatisticamente significantes foram observadas do 20 para o $14^{\circ}$ dia nas úlceras tratadas com solução fisiológica $(p<0,01)$, creme base $(p<0,001)$ e creme a $10 \%$ de óleo-resina $(p<0,05)$; do 20 para o 70 dia nas úlceras tratadas com solução fisiológica $(p<0,001)$, creme base $(p<0,01)$ e creme a $10 \%$ de óleo-resina $(p<0,01)$.

A atividade da pró-MMP-2 diminuiu discretamente durante o período de seguimento nas úlceras tratadas com solução fisiológica e creme base (Figura 58b), enquanto nas úlceras tratadas com creme a $10 \%$ de óleo-resina houve aumento discreto de atividade do $2^{\circ}$ para o 70 dia e diminuição do 70 para 0140 dia. Diferenças estatisticamente significantes foram observadas do $2^{\circ}$ para $014^{\circ}$ dia nas úlceras tratadas com creme base $(p<0,05)$.

Houve diminuição progressiva da atividade da MMP-9 durante o período de seguimento para as úlceras tratadas com solução fisiológica e creme base, enquanto para aquelas tratadas com creme a $10 \%$ de óleo-resina houve aumento de atividade enzimática do $2^{\circ}$ para o 70 dia e diminuição do 70 para o $14^{\circ}$ dia (Figura 58c). Diferenças estatisticamente significantes foram observadas do $2^{\circ}$ para $014^{\circ}$ dia nas úlceras tratadas solução fisiológica $(p<0,05)$, creme base $(p<0,05)$ e creme a $10 \%$ de óleo-resina $(p<0,05)$; do 20 para o 70 dia nas úlceras tratadas com creme base $(p<0,05)$; do 70 para 0140 dia nas úlceras tratadas com solução fisiológica $(p<0,01)$ e creme a $10 \%$ de óleo-resina $(p<0,001)$. No 70 dia, a atividade da MMP-9 nas úlceras tratadas com creme contendo $10 \%$ de óleo-resina foi significantemente superior a atividade enzimática nas úlceras tratadas solução fisiológica $(p<0,05)$. No 140 dia, 
nenhuma atividade proteolítica da MMP-9 foi encontrada nas úlceras tratadas com creme base e creme a $10 \%$ de óleo-resina de copaíba.
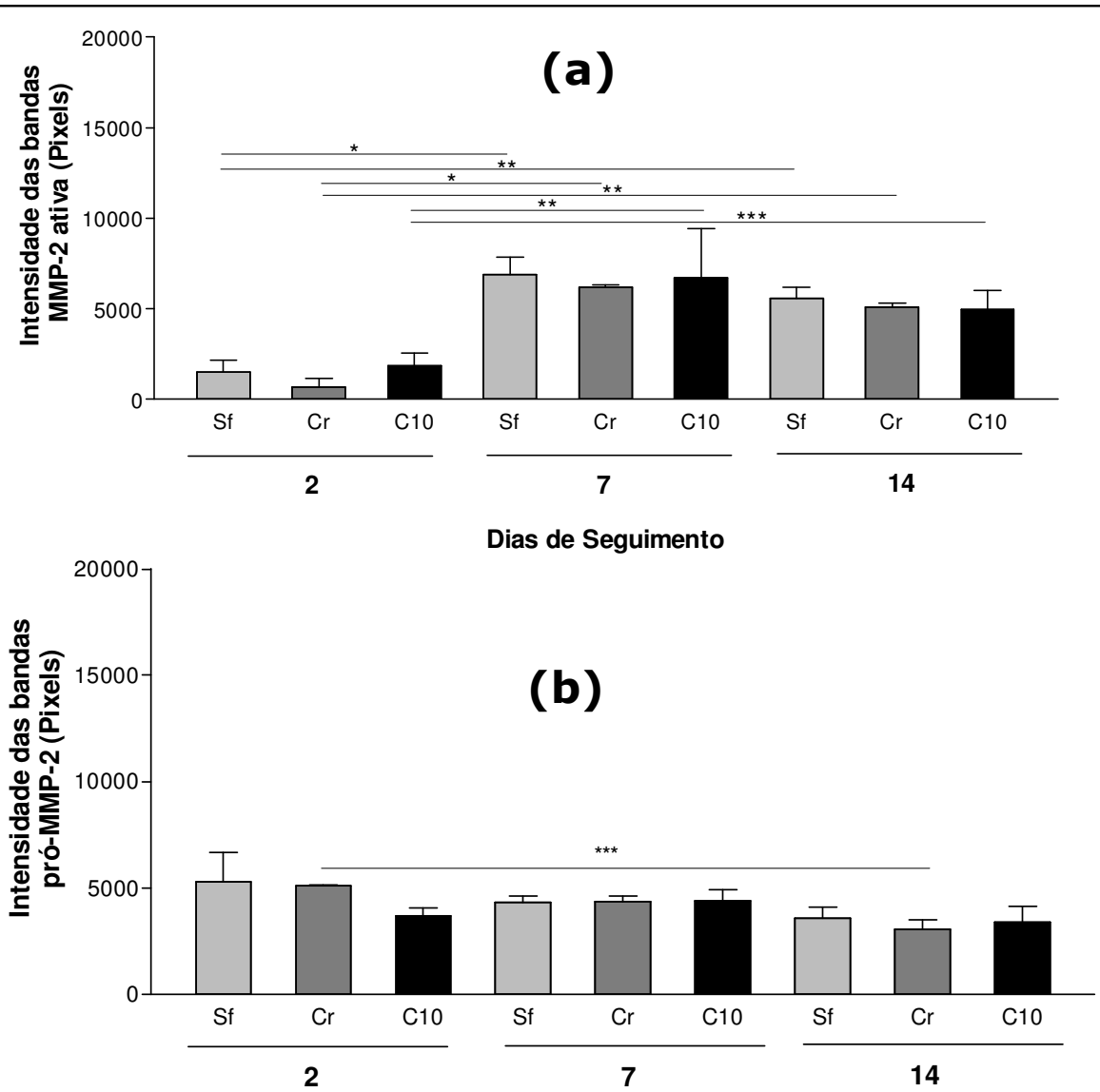

Dias de Seguimento

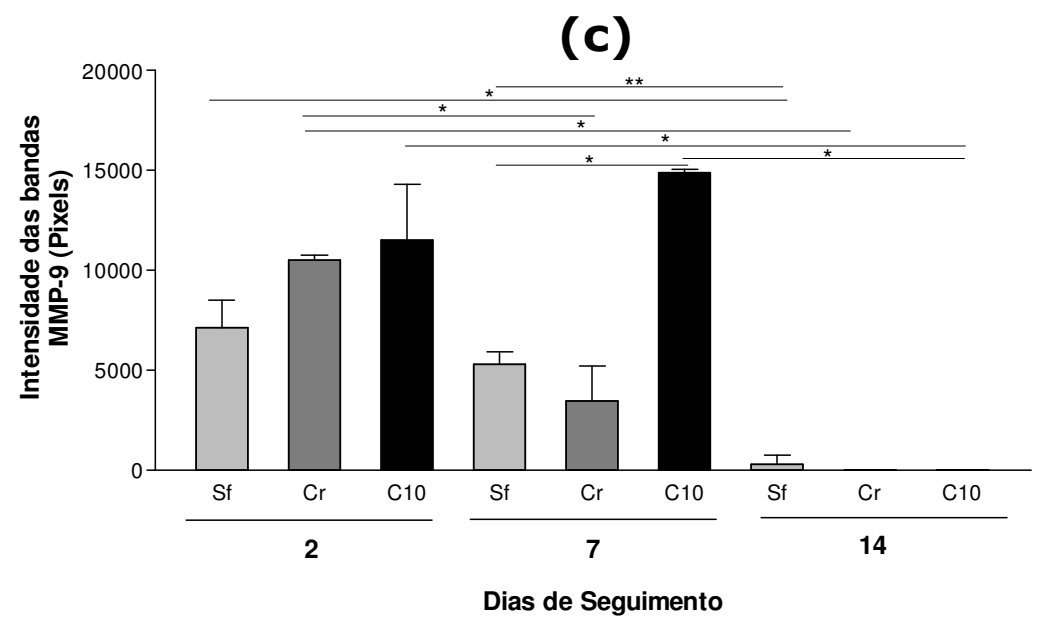

Figura 58 - Atividade das metaloproteinases 2 (a, b) e 9 (c) durante o seguimento das úlceras infectadas com $S$. aureus nos dias 2, 7 e 14, conforme os tratamentos: Solução fisiológica (Sf), Creme base ( $\mathrm{Cr}$ ) e Creme a $10 \%$ de óleo-resina de copaíba (C10). Os valores representam a média \pm desvio-padrão da medida da intensidade das bandas, em triplicata, a partir dos zimogramas $(n=3)$. Diferenças estatisticamente significantes: $(*)$ $\mathrm{p}<0,001,(* *) \mathrm{p}<0,01$ e (***) $\mathrm{p}<0,05$. 


\subsection{2 Úlceras infectadas com S. pyogenes}

\subsubsection{Seguimento clínico-experimental}

A Figura 59 representa o seguimento clínico-fotográfico das úlceras infectadas com S. pyogenes. No $2^{0}$ dia após o procedimento cirúrgico e inoculação da suspensão bacteriana, todas as úlceras apresentavam evidência clínica de infecção local, como exsudato purulento [principalmente as úlceras tratadas com creme base (Figura 59f) e creme a 10\% de óleo-resina (Figura 59j] eritema (principalmente as úlceras do grupo solução fisiológica (Figura 59b). A presença de pus foi observada no período de 1 a 3 dias após o procedimento cirúrgico em todos os grupos. As úlceras tratadas com creme base e creme a $10 \%$ de óleo-resina encontravam-se mais úmidas que as demais, principalmente durante os 3 primeiros dias de seguimento.

No 70 dia, ainda evidenciava-se a presença de eritema, principalmente nas úlceras tratadas com solução fisiológica (Figura 59c) e creme base (Figura $\mathbf{5 9 g}$ ). As áreas ulceradas estavam menores, principalmente no grupo creme a 10\% de óleo-resina (Figura $\mathbf{5 9 j}$ ).

No 140 dia, a maioria das úlceras estava reepitelizada, embora a qualidade do tecido cicatricial nas úlceras tratadas com creme contendo $10 \%$ de óleo-resina de copaíba parecia estar superior aos demais grupos (Figuras 59d, h, I).

Durante todo o seguimento não foi observado qualquer sinal de infecção sistêmica, visto que os animais mantiveram-se ativos e alimentando-se normalmente. 


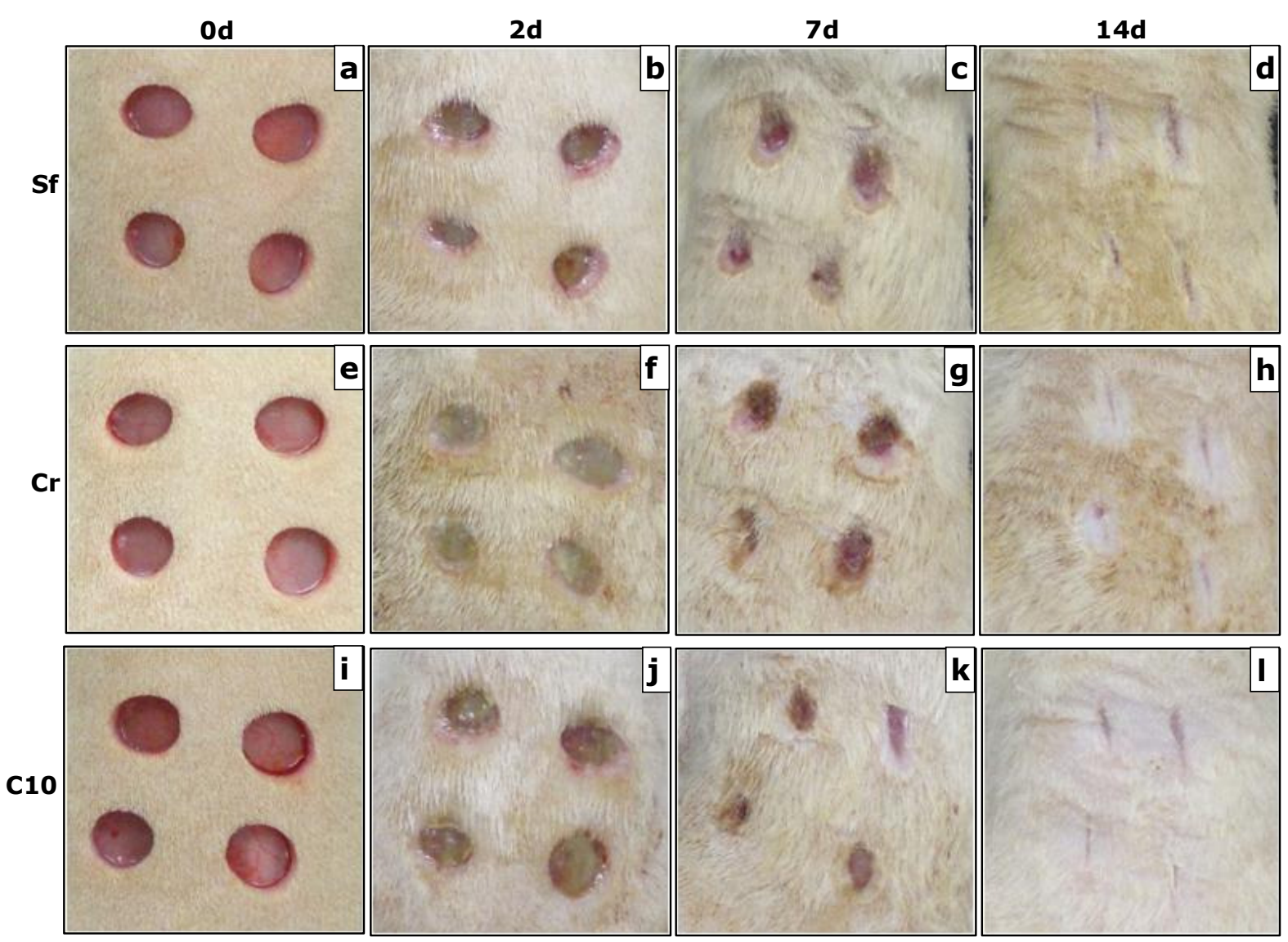

Figura 59 - Seguimento clínico das úlceras infectadas com S. pyogenes nos dias 0, 2, 7 e 14 respectivamente, conforme os tratamentos: Solução fisiológica (Sf) (a-d); Creme base (Cr) (e-h); Creme a 10\% de óleo-resina de copaíba (C10) (i-I)

\subsubsection{2 Índices de Cicatrização das Úlceras (ICU)}

No $2^{\circ}$ dia após o procedimento cirúrgico, os valores de ICU para o grupo tratado com creme a $10 \%$ de óleo-resina de copaíba foram superiores quando comparados aos valores de ICU dos grupos tratados com solução fisiológica $(p<0,05)$ e creme base (Figura 60).

No 70 dia, os valores de ICU para as úlceras tratadas com creme a $10 \%$ de óleo-resina foram superiores aos demais grupos, com diferença estatisticamente significante quando comparados aos valores de ICU do grupo tratado com creme base $(0<0,01)$.

No $14^{\circ} \mathrm{dia}$, as úlceras tratadas com creme a $10 \%$ óleo-resina estavam reepitelizadas, assim como a maioria das úlceras tratadas com creme base. Algumas úlceras tratadas com solução fisiológica ainda não estavam completamente reepitelizadas (valores de ICU entre 0,77 e 0,98), estatisticamente diferentes quando comparados ao grupo tratado com creme a $10 \%$ de óleo resina $(p<0,05)$. 


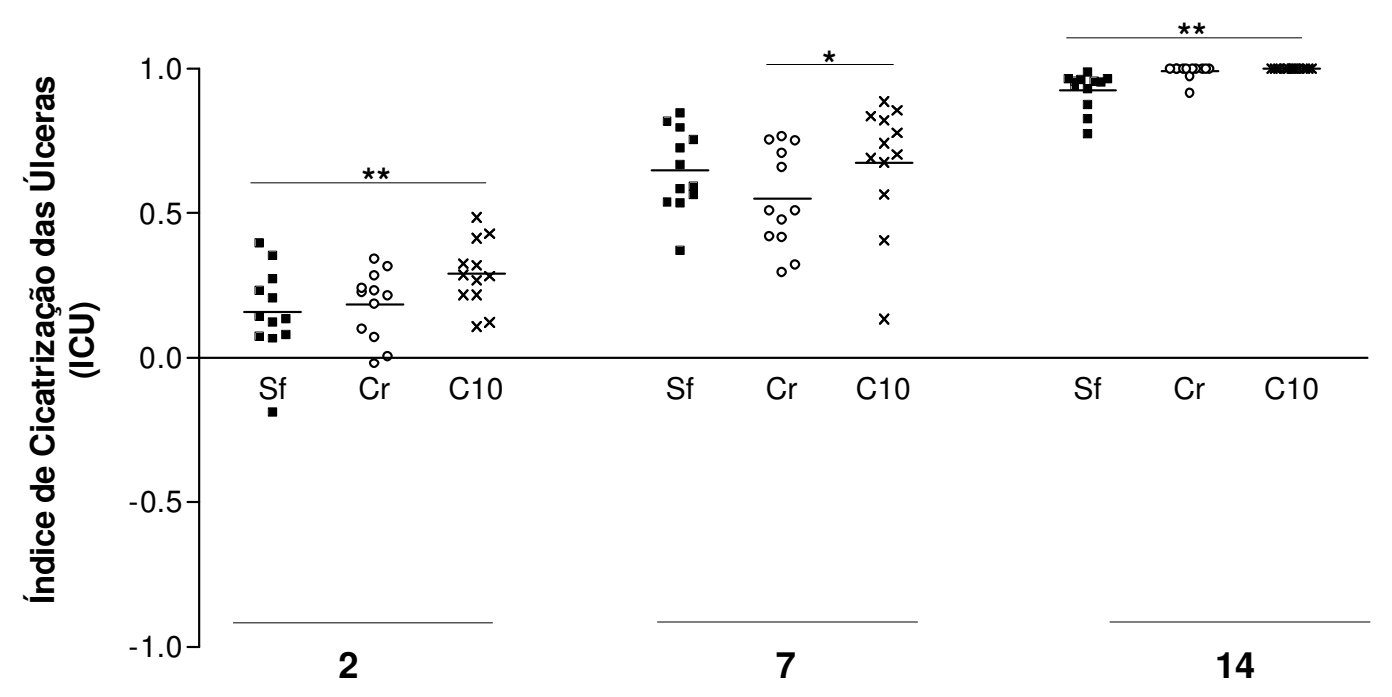

Dias de Seguimento

Figura 60 - Evolução dos índices de cicatrização das úlceras infectadas com S. pyogenes, nos dias de 2, 7 e 14 dias conforme os tratamentos: Solução fisiológica (Sf), Creme base controle ( $\mathrm{Cr}$ ) e Creme contendo $10 \%$ de óleo-resina de copaíba (C10). $(n=12)$. Os valores representam a média \pm desvio-padrão $(n=12)$. Diferenças estatisticamente significantes: $(*) p<0,01 ;(* *) p<0,05$.

\subsubsection{Avaliação Histopatológica}

No $2^{\circ}$ dia após o procedimento cirúrgico, observou-se intenso infiltrado inflamatório nas lâminas correspondentes às úlceras tratadas com creme base (Figura 61d) e creme a 10\% de óleo-resina de copaíba (Figura 61g) embora o grupo solução fisiológica também tenha apresentado infiltrado inflamatório importante.

No 70 dia, todos os grupos apresentaram evidência de atividade fibroblástica, observada principalmente nas lâminas correspondentes às úlceras tratadas com creme base (Figura 61e) e creme a 10\% de óleo-resina (Figura 61h). As lâminas correspondentes às úlceras tratadas com solução fisiológica (Figura 61b) e creme a 10\% de óleo-resina ainda apresentavam importante infiltrado inflamatório (Figura 61c).

No $14^{\circ}$ dia, as lâminas correspondentes às úlceras tratadas solução fisiológica apresentaram mais fibroblastos (Figura 61c) que os grupos creme base (Figura 61f) e creme a 10\% de óleo-resina (Figura 61i). 
A análise qualitativa da colagênese também foi realizada pela coloração das lâminas com o tricrômio de Gomori (Figura 62). Em todos os grupos avaliados, a intensidade de cor na área da úlcera/ tecido cicatricial aumentou gradualmente durante o seguimento, indicando, qualitativamente, aumento da colagênese. Quando foram compadas as lâminas no $14^{\circ}$ dia após o procedimento cirúrgico, a intensidade de coloração parecia estar discretamente aumentada nas lâminas correspondentes às úlceras tratadas com solução fisiológica (Figura 62c) comparada aos demais grupos (Figura 62f, i).
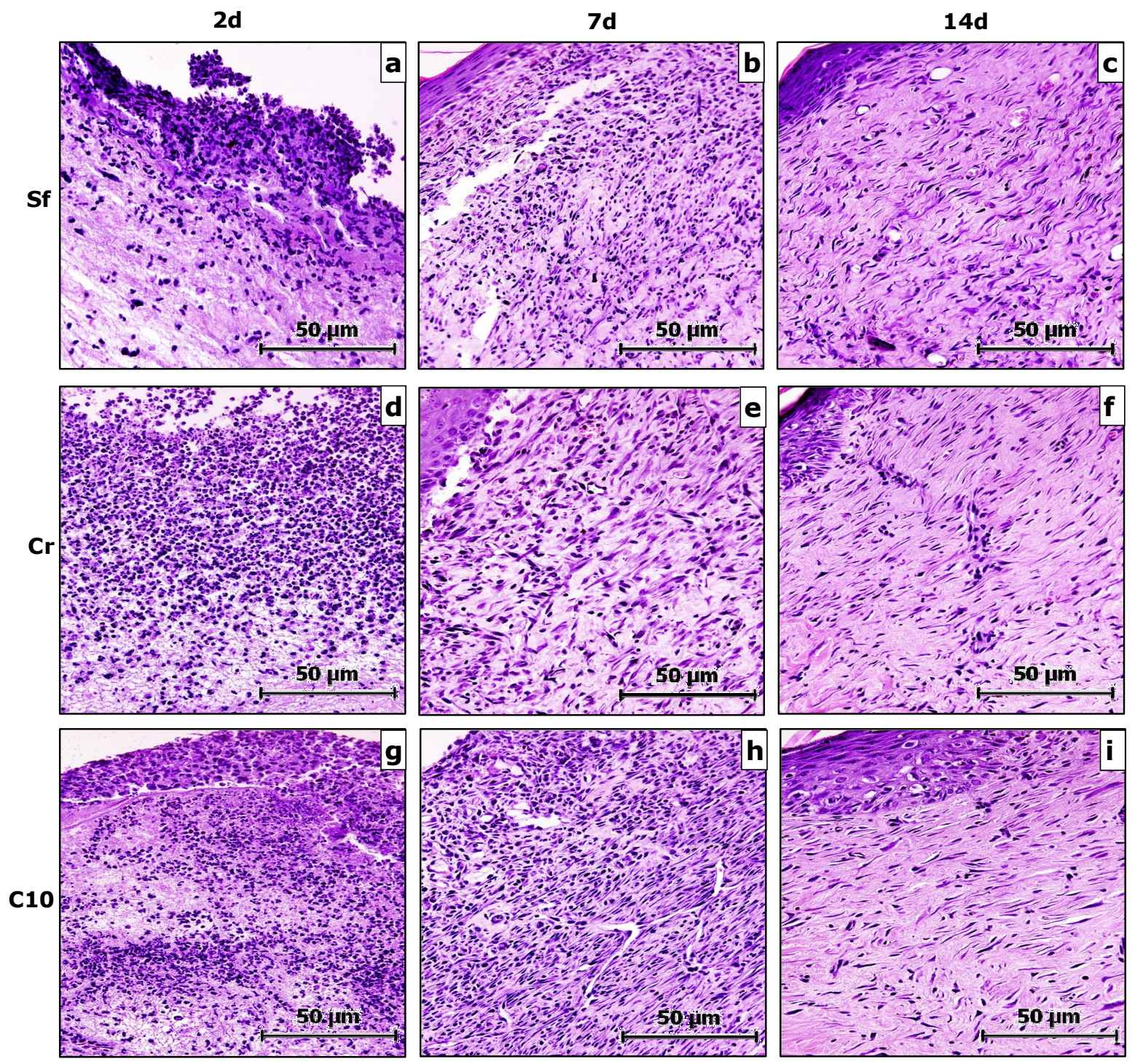

Figura 61 - Avaliação histopatológica das úlceras infectadas com S. pyogenes nos dias 2, 7 e 14 respectivamente, conforme os tratamentos: Solução fisiológica (Sf) (a-c); Creme base (Cr) (d-f); Creme a 10\% de óleo-resina de copaíba (C10) (g-i). Coloração hematoxilina-eosina. Aumento de 400x. 

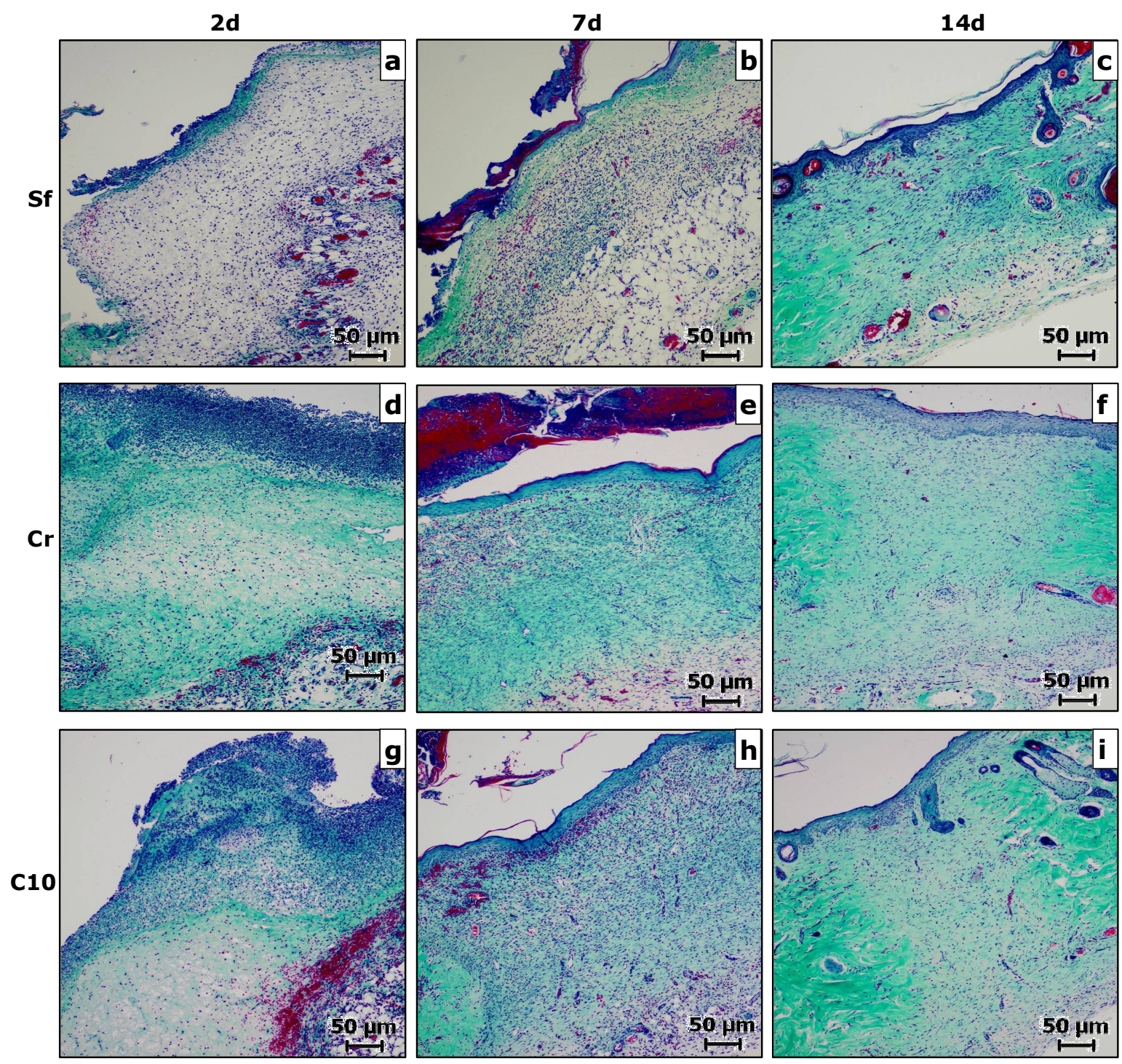

Figura 62 - Avaliação histopatológica das úlceras infectadas com S. pyogenes nos dias 2, 7 e 14 respectivamente, conforme os tratamentos: Solução fisiológica (Sf) (a-c); Creme base (Cr) (d-f); Creme a 10\% de óleo-resina de copaíba (C10) (g-i). Coloração tricrômio de Gomori. Aumento de 100x.

\subsubsection{Avaliação Bioquímica: Dosagem de Hidroxiprolina}

Houve aumento progressivo da concentração de hidroxiprolina durante o seguimento das úlceras para todos os grupos. No $14^{\circ}$ dia, a concentração de hidroxiprolina foi maior nas úlceras tratadas com creme a $10 \%$ de óleo-resina, comparado aos outros grupos, evidenciando um possível efeito positivo do óleoresina de copaíba na colagênese (Figura 63). 


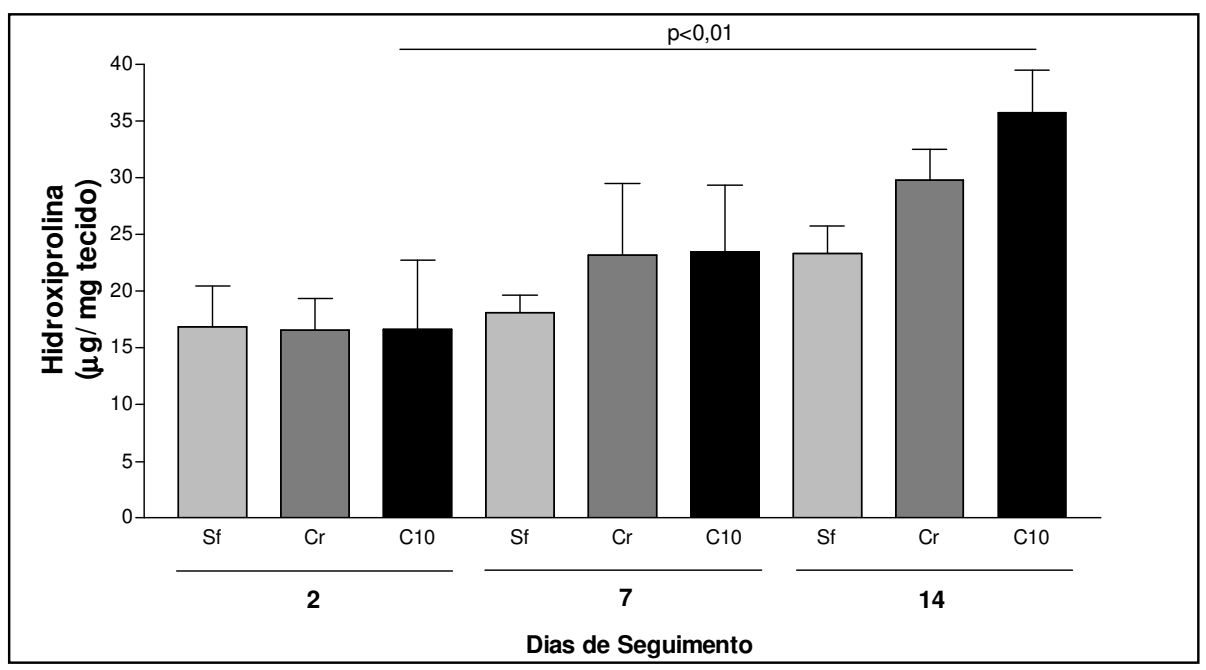

Figura 63 - Concentração de hidroxiprolina durante o seguimento das úlceras infectadas com $S$. pyogenes nos dias 2, 7 e 14 conforme os tratamentos: Solução fisiológica (Sf), Creme base (Cr) e Creme a $10 \%$ de óleo-resina de copaíba (C10). Os valores representam a média \pm desvio-padrão da análise em triplicata $(n=3)$. Diferenças estatisticamente significante $(p<0,01)$.

\subsubsection{Avaliação Bioquímica: Dosagem de Metaloproteinases}

A Figura 64 representa a imagem digitalizada de um dos géis após a zimografia, demonstrando a presença das metaloproteinases 2 (ativa; pró ou inativa) e 9 , representadas pelas bandas claras.

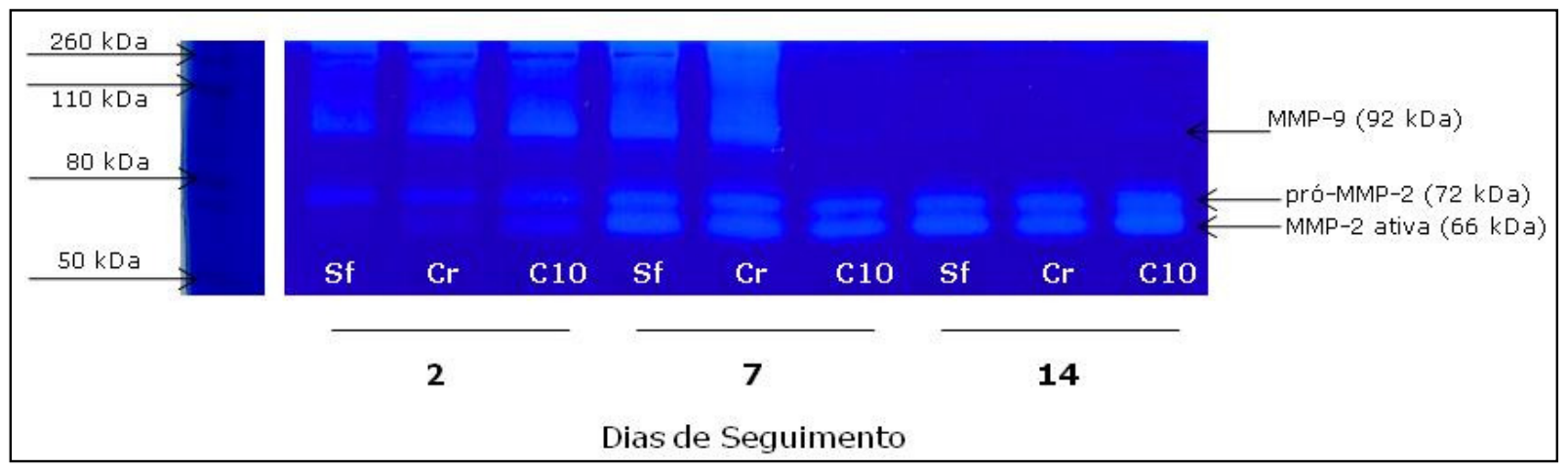

Figura 64 - Imagem digitalizada do gel de zimografia (zimograma) representando a atividade proteolítica das MMPs durante o seguimento das úlceras infectadas com S. pyogenes nos dias 2, 7 e 14 conforme os tratamentos: Solução fisiológica (Sf), Creme base (Cr) e Creme a 10\% de óleoresina de copaíba (C10). As bandas coradas em azul escuro representam o padrão de peso molecular.

Houve aumento progressivo da atividade da MMP-2 ativa durante o período de seguimento para as úlceras tratadas com crem base e creme a $10 \%$ de óleo-resina, enquanto para aquelas tratadas com solução fisiológica houve 
aumento de atividade enzimática do $2^{\circ}$ para 070 dia e diminuição do 70 para 0 $14^{\circ}$ dia (Figura 65a). Diferenças estatisticamente significantes foram observadas do $2^{\circ}$ para o $14^{\circ}$ dia nas úlceras tratadas com creme base $(p<0,01)$; do $2^{\circ}$ para 070 dia nas úlceras tratadas com solução fisiológica $(p<0,001)$ e creme base $(p<0,05)$. No $14^{\circ}$ dia, a atividade enzimática da MMP-2 foi superior nas úlceras tratadas com creme a $10 \%$ de óleo-resina comparada aos grupos controles, porém sem diferença estatisticamente significante.

A atividade da pró-MMP-2 diminuiu discretamente nas úlceras tratadas com solução fisiológica durante o período de seguimento. A atividade enzimática nas úlceras tratadas com creme base e creme a $10 \%$ de óleo-resina diminuiu do $2^{\circ}$ para o 70 dia e aumentou discretamente do 70 para o $14^{\circ}$ dia. Porém, sem diferenças estatisticamente significantes (Figura 65b).

Houve diminuição progressiva da atividade da MMP-9 durante o período de seguimento para as úlceras tratadas com solução fisiológica e creme base, enquanto nas úlceras tratadas com creme a 10\% de óleo-resina, a atividade manteve-se praticamente inalterada do $2^{\circ}$ para o 70 dia, com diminuição no $14^{\circ}$ dia (Figura 65c). Diferença estatisticamente significante foi observada do 20 para o $14^{\circ}$ dia nas úlceras tratadas com creme base $(p<0,05)$. No $14^{\circ}$ dia, a atividade proteolítica da MMP-9 estava praticamente ausente nas úlceras tratadas com creme a $10 \%$ de óleo-resina. 


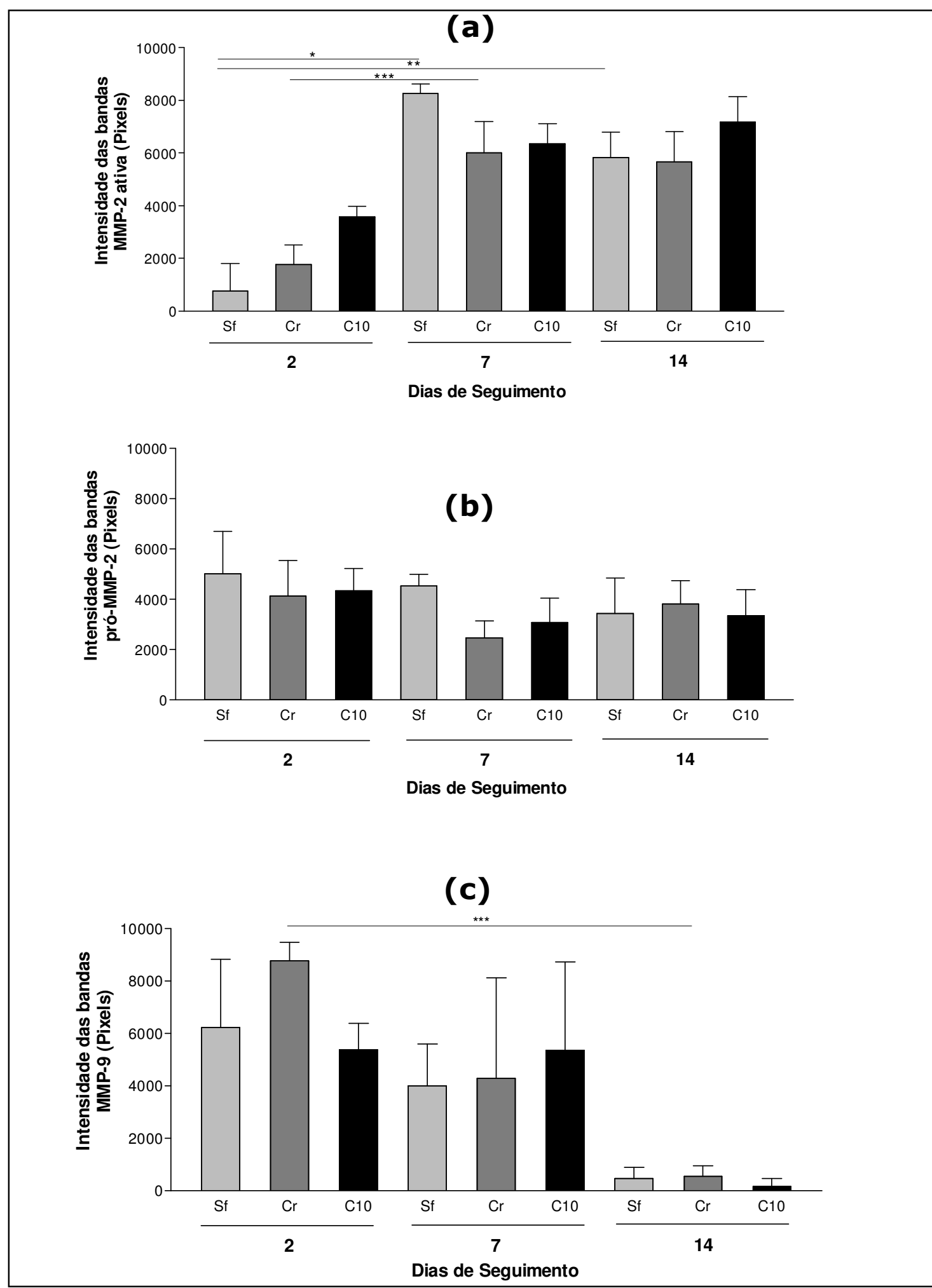

Figura 65 - Atividade das metaloproteinases 2 (a, b) e 9 (c) durante o seguimento das úlceras infectadas com $S$. pyogenes nos dias 2, 7 e 14, conforme os tratamentos: Solução fisiológica (Sf), Creme base $(\mathrm{Cr})$ e Creme a $10 \%$ de óleo-resina de copaíba (C10). Os valores representam a média \pm desvio-padrão da medida da intensidade das bandas, em triplicata, a partir dos zimogramas $(n=3)$. Diferenças estatisticamente significantes: $(*) p<0,001,(* *) p<0,01$ e $(* * *) p<0,05$. 


\section{Discussão}

"Loucura? Sonho? Tudo é loucura ou sonho no começo. Nada do que o homem fez no mundo teve início de outra maneira, mas tantos sonhos se realizaram que não temos o direito de duvidar de nenhum". 


\section{DISCUSSÃO}

Úlceras cutâneas constituem um importante problema de saúde pública que afeta milhões de pacientes em todo o mundo, devido a sua cronicidade (RANZATO et al., 2011) e alta morbidade. O processo de cicatrização é extremamente complexo e caracterizado por uma série progressiva de eventos celulares, moleculares e bioquímicos com o objetivo de restaurar a integridade mecânica e função barreira da pele (SCHULTZ et al., 2011). Estudos para a melhor compreensão do processo cicatricial, assim como, a busca por alternativas para o tratamento dos pacientes são constantes e incessantes. Muitos produtos naturais são conhecidos por apresentarem propriedades cicatrizantes, baseadas no conhecimento popular e evidências científicas (RANZATO et al., 2011).

Vários estudos vêm sendo realizados para avaliar as propriedades antiinflamatória, analgésica, antibacteriana e cicatrizante, relatadas com o uso do óleo de copaíba (MONTES et al., 2009). Levando em consideração a sua utilização popular e a necessidade de evidências científicas a respeito dos efeitos do óleo-resina de copaíba, o presente estudo teve como objetivo principal avaliar este composto na cicatrização de úlceras cutâneas, infectadas ou não, de forma a comprovar o que é conhecido popularmente.

Avaliou-se a citotoxicidade do óleo-resina da Copaifera langsdorffii em culturas celulares de fibroblastos $\mathrm{NIH}-3 \mathrm{~T} 3$ pelos testes de viabilidade e proliferação celular.

A viabilidade dos fibroblastos diminuiu com o aumento da concentração do óleo-resina de copaíba, entretanto, mesmo nas concentrações mais altas de óleo-resina (500 e $1000 \mu \mathrm{g} / \mathrm{mL}$ ) cerca de 70\% das células ainda estava viável, comparadas ao controle, o que comprova a baixa tocixidade do óleo-resina da copaiba.

Quanto à proliferação celular, a concentração de $50 \mu \mathrm{g} / \mathrm{mL}$ de óleo-resina promoveu a proliferação dos fibroblastos com mais de $100 \%$ de células mitoticamente competentes, superior ao controle, propriedade importante para sua indicação como cicatrizante. Entretanto, sua atividade proliferativa apresentou um perfil dose-dependente com declínio na proliferação celular de 65 a $70 \%$ nas concentrações de 500 e $1000 \mu \mathrm{g} / \mathrm{mL}$ respectivamente. 
SANTOS et al. (2008a), avaliaram a citotoxicidade do óleo-resina obtido da Copaifera reticulata em culturas celulares de macrófagos, que relataram baixa citotoxicidade deste óleo-resina para macrófagos J774G8, e citam estudos prévios que consideram que na concentração de $500 \mu \mathrm{g} / \mathrm{mL}$ o óleo resina da $C$ reticulata não alterou a viabilidade de macrófagos peritoneais.

Os resultados obtidos no presente estudo foram similares aos encontrados por Lima et al. (2003), que avaliaram a citotoxicidade do óleoresina obtido da $C$. multijuga, bem como suas frações em células de melanoma nas concentrações de 500 e $1000 \mu \mathrm{g} / \mathrm{mL}$ nos períodos de 1 e 3 horas, observando redução do número de células viáveis de maneira dose e tempodependentes.

Também poderia se associar aos resultados encontrados os descritos por Veiga Júnior et al. (2007), que avaliaram a citotoxicidade de óleo-resinas provenientes das C. multijuga Hayne, C. cearensis Huber ex Ducke and C. reticulata em culturas de macrófagos do peritônio de ratos, pelo método MTT. As concentrações dos óleo-resinas foram de 5, 50 e $500 \mu \mathrm{g} / \mathrm{mL}$. Os óleo-resinas provenientes da C. multijuga Hayne e da C. cearensis Huber ex Ducke foram citotóxicos na concentração de $500 \mu \mathrm{g} / \mathrm{mL}$, reduzindo o número de células viáveis a 5 e $6 \%$, respectivamente, enquanto que na concentração de $50 \mu \mathrm{g} / \mathrm{mL}$ mais de $93 \%$ das células permaneceram viáveis. O óleo-resina proveniente da $C$. reticulata Ducke não alterou a viabilidade dos macrófagos nas concentrações testadas.

Burd et al. (2007), avaliaram os perfis de citotoxicidade de curativos usados no tratamento de úlceras cutâneas contendo prata, pré-tratados com soluções diferentes (água, solução fisiológica ou soro bovino fetal) em culturas de fibroblastos e queratinócitos humanos através do método MTT. Os autores usaram termos como citotoxicidade moderada e significativa quando cerca de 75 e $25 \%$ das células estavam viáveis após 24 horas de cultura. O termo citotoxicidade severa foi utilizado quando cerca de $80 \%$ das células foram mortas em torno de 2 horas após a aplicação do tratamento e em torno de 1,6\% das células permaneceram viáveis após 24 horas de cultura. Adequando estas terminologias aos resultados obtidos nesse trabalho, pode-se inferir que o óleoresina de copaíba nas concentrações de 500 e $1000 \mu \mathrm{g} / \mathrm{mL}$ foi moderadamente citotóxico, ressaltando que não foi citotóxico aos fibroblastos nas concentrações de 10,50 e $100 \mu \mathrm{g} / \mathrm{mL}$. 
Quanto à propriedade cicatrizante, primeiramente, utilizou-se o modelo de úlcera cutânea não-contrátil na superfície dorsal da orelha de coelhos.

Neste modelo, todas as úlceras, exceto aquelas que receberam a aplicação tópica do óleo-resina in natura, estavam reepitelizadas ao final do seguimento (21 dias após o procedimento cirúrgico). No entanto, as úlceras tratadas com creme a $10 \%$ de óleo-resina de copaíba, apresentaram índices de cicatrização superiores, comparados aos demais grupos, principalmente no 70 e $14^{\circ}$ dias, além de apresentarem tecido cicatricial superior aos demais grupos. $\mathrm{Na}$ avaliação histopatológica também foi possível observar que as úlceras tratadas com creme a $10 \%$ de óleo-resina apresentaram fibras colágenas mais organizadas desde o $14^{\circ}$ dia.

O aumento dos ICUs, ou seja, a diminuição das áreas das úlceras tratadas com creme a $10 \%$ de óleo-resina de copaíba e a organização dos feixes de colágeno sugerem uma ação benéfica deste produto na formação tecidual e remodelamento.

Os animais que receberam o óleo-resina in natura desenvolveram novas lesões circunjacentes às úlceras a partir do $2^{\circ}$ dia de seguimento, com irritação cutânea importante por intenso processo inflamatório no 70 dia e retardo da cicatrização das úlceras. Estes sinais clínicos foram confirmados pela avaliação histopatológica, uma vez que observou-se intenso infiltrado inflamatório no $2^{\circ} \mathrm{e}$ 70 dias. Ao final do seguimento a integridade da pele lesada estava recuperada e a maioria das úlceras estava cicatrizada.

Um estudo que avaliou a aplicação de óleo-resina de copaíba puro em úlceras cutâneas abertas em ratos teve como resultado o aumento de área das lesões e a perda de pêlos ao redor das úlceras (BRITO et al., 1998). Estes mesmos autores, em outro trabalho (BRITO et al., 1999), avaliaram os aspectos microscópicos da cicatrização de úlceras cutâneas abertas de ratos após aplicação de óleo de copaíba puro comparados ao grupo controle tratado com solução fisiológica. Nas úlceras tratadas com o óleo-resina de copaíba os autores observaram: maior processo inflamatório em todos os dias do estudo; tecido de granulação mais desenvolvido; contagem dos vasos sanguíneos foi significativamente maior. Entretanto, a contagem de fibras colágenas, apresentou aumento crescente em ambos os grupos no decorrer do experimento, sendo que no grupo controle foi maior que no grupo copaíba em todos os dias observados. 
Um dos efeitos colaterais mais comuns causado pelo uso de plantas medicinais é a hipersensibilidade, que pode variar de uma dermatite temporária até um choque anafilático (VEIGA JúNIOR; PINTO; MACIEL, 2005). Toda substância não-inócua aplicada topicamente causa irritação tecidual, que demanda uma resposta inflamatória em diferentes graus (CAVALCANTI NETO et al., 2005). Embora o fator principal do processo inflamatório nessa fase seja o trauma cirúrgico, os resultados encontrados permitem inferir que o óleo-resina, quando aplicado na sua forma in natura, foi mais irritante em relação a todos os outros tratamentos aplicados.

Estudos com plantas medicinais vêm mostrando que constituintes fitoquímicos como triterpenos, flavonóides e taninos podem promover o processo de cicatrização, principalmente devido às suas propriedades adstringentes e antimicrobianas, as quais parecem ser responsáveis pela contração da úlcera e taxa de reepitelização aumentada (DESHMUKH et al., 2009; SHIVHARE et al., 2010).

Análises químicas dos óleos de copaíba apontam que são constituídos por misturas de sesquiterpenos e diterpenos, em diferentes concentrações. Sua fração mais volátil é composta por sesquiterpenos, enquanto a fração resinosa é composta por diterpenos (GOMES et al., 2007; MENDONÇA; ONOFRE, 2009; RIGAMONTE-AZEVEDO et al., 2004; VEIGA JÚNIOR; PINTO; MACIEL, 2005).

As concentrações e a natureza dos sesquiterpenos e diterpenos podem variar, porém estão sempre presentes nos óleos de copaíba (MONTES et al., 2009). A maioria destas substâncias ocorre apenas na espécie Copaifera (FERNANDES; FREITAS, 2007), substâncias responsáveis pelas propriedades biológicas dos óleo-resinas, como analgésica, antiinflamatória, anti-séptica, cicatrizante, entre outras, quando aplicados via oral ou tópica (CAVALCANTI NETO et al., 2005).

O óleo-resina utilizado no presente estudo foi caracterizado por cromatografia gasosa de alta resolução acoplada a um espectrofotômetro de massa por Ramos (2006). A análise mostrou que o óleo-resina apresenta uma mistura de sesquiterpenos (75\%) e diterpenos (25\%). Os principais sesquiterpenos identificados foram o $\beta$-cariofileno $(51 \%)$, seguido por $a$ humuleno $(8,52 \%)$; dentre os diterpenos, os principais compostos identificados foram o ácido 11-acetoxi-copálico (5,23\%), o ácido 11-hidróxi-copálico (4,8\%), ácido copálico $(4,69 \%)$ e ácido agático $(3,32 \%)$. 
Estes achados foram semelhantes aos encontrados na literatura, como por exemplo, nos trabalhos de Sousa et al. (2010), os quais reportaram a presença $90 \%$ de sesquiterpenos e pequena quantidade de diterpenos, em óleoresinas disponíveis comercialmente, onde os principais compostos identificados foram $\beta$-cariofileno, a-copaeno, a-humuleno.

Em outros estudos que se caracterizou quimicamente o óleo-resina de copaíba, resultados semelhantes a estes foram observados (LIMA et al., 2003; MENDONCA e ONOFRE, 2009; RIGAMONTE-AZEVEDO et al., 2004; VASCONCELOS et al., 2008; VEIGA JÚNIOR et al., 2007).

A propriedade cicatrizante do óleo-resina de copaíba poderia ser atribuída aos fitoconstituintes presentes, seja de um único composto ou por efeitos aditivos da combinação dos constituintes do óleo (SHIVHARE et al., 2010).

Em um estudo conduzido por Paiva et al. (2002), no qual o óleo-resina de copaíba (na concentração de 4\%) foi topicamente aplicado em úlceras excisionais e incisionais em ratos, os autores observaram melhora na contração das úlceras no 90 dia após o procedimento cirúrgico, nas úlceras excisionais. Tem sido sugerido que o fator comum na contração da úlcera é a atividade dos miofibroblastos, os quais são encontrados no tecido de granulação nas úlceras em processo normal de cicatrização. Vários constituintes presentes no óleoresina de copaíba, tais como os terpenos ou a presença de algum fator de crescimento desconhecido que promova a formação colagênica, similar ao TGF- $\beta$, poderiam ter contribuído para a contração inicial da úlcera. Neste estudo, os autores ainda observaram aumento da força tensora no $5^{\circ}$ dia após o procedimento cirúrgico nas úlceras incisionais. Estes achados indicam que o óleoresina de copaíba poderia acelerar a cicatrização in vivo.

Por outro lado, Cavalcanti Neto et al. (2005), acreditam que o efeito cicatrizante do óleo de copaíba poderia ser indireto devido às suas propriedades antiinflamatórias, o que reduz a fase exsudativa que ocorre nos primeiros dias do processo de reparo. Essa ação antiedematogênica foi constatada por Veiga Júnior et al. (2001), e pode ser atribuída à inibição da permeabilidade vascular, apesar de seu exato mecanismo de ação ainda permanecer obscuro.

Pela composição do óleo-resina utilizado nesse trabalho, pode-se inferir que o composto $\beta$-cariofileno, por ter sido identificado em maior concentração no óleo, poderia ser o responsável pelas atividades observadas, seja isoladamente ou através de efeitos sinérgicos a outros componentes do óleo-resina. Sua 
atividade antiinflamatória, descrita na literatura, poderia ter um efeito positivo em fazer com que a fase inflamatória do processo cicatricial seja breve, estimulando as úlceras a prosseguirem para as fases subsequentes de proliferação, maturação e remodelamento.

A resposta inflamatória é um passo importante no processo cicatricial uma vez que prepara o ambiente da úlcera para o processo de reparo. Entretanto, esta fase não deve ser muito intensa, porque um excesso de resposta inflamatória pode retardar a cicatrização, além de favorecer o distúrbio no equilíbrio entre síntese e degradação de colágeno e promoção de degradação da matriz (ARAUJO et al., 2010).

No modelo de úlceras contráteis no dorso dos ratos, as úlceras tratadas com creme a $10 \%$ de óleo-resina e creme base estavam mais úmidas que aquelas tratadas com solução fisiológica no $2^{\circ}$ dia o que levou ao aumento das áreas ulceradas, coincidente com intenso infiltrado inflamatório encontrado nesse grupo. No entanto, no 70 e $14^{\circ}$ dias, as úlceras tratadas com creme a $10 \%$ de óleo-resina mostraram melhor perfil de cicatrização, tanto clinicamente quanto pelos ICUs, superior aos demais grupos. Ao final do seguimento, as úlceras tratadas com creme a $10 \%$ de óleo-resina estavam reepitelizadas e a avaliação histopatológica mostrou fibras colagênicas mais maduras e organizadas, quando comparadas aos controles.

No estudo conduzido por Araujo et al. (2010), que teve como objetivo avaliar e caracterizar o perfil cicatricial induzido pela alantoína (5\%) incorporada em uma emulsão óleo/água em úlceras excisionais na região dorsal de ratos, os autores observaram resultados similares aos encontrados nesse trabalho quanto ao aumento da área ulcerada no grupo tratado com creme contendo alantoína no 30 dia de seguimento. No entanto, os autores discutem este aumento da área como uma característica dos animais de experimentação e não quanto à formulação estudada. Referem-se à tensão do tecido elástico circunjacente e perda de aderência da fáscia profunda assim como a mobilidade da pele do rato.

Além do aumento da área das úlceras no $2^{\circ}$ dia, observou-se também que estas mesmas úlceras encontravam-se mais úmidas que aquelas que receberam solução fisiológica, o que nos leva a pensar que o creme, contendo ou não o óleo-resina poderia ter influenciado na manutenção da umidade do leito, o que poderia ser uma característica importante, visto que certa umidade do leito pode favorecer o processo cicatricial nessa fase. 
A umidade no leito da úlcera facilita o desbridamento autolítico, ou seja, a degradação natural do tecido desvitalizado pela ação de enzimas como as hidrolases ácidas, e a mobilidade celular. É proposto que a hidratação da úlcera estimule a epitelização, a formação do tecido de granulação e a angiogênese, além de atrair fibroblastos e estimular a síntese colagênica e remodelamento. Além disso, evita a desidratação tecidual diminuindo possíveis traumatismos durante a troca diária dos curativos (KUMAR et al., 2008; NARDI et al., 2004).

De forma a entender o possível mecanismo de ação do óleo-resina de copaíba, experimentos utilizando parâmetros bioquímicos importantes no processo cicatricial, como o conteúdo de colágeno, estimado pela quantidade de hidroxiprolina e a atividade das metaloproteinases de matriz foram realizados.

A dosagem de hidroxiprolina nas úlceras tratadas com creme a $10 \%$ de óleo-resina de copaíba foi superior ao conteúdo dos grupos controles no 70 e 140 dias, o que demonstra que houve maior deposição colagênica no grupo tratado com creme a $10 \%$ de óleo-resina.

Também foi observado que a pele ulcerada, independente do tratamento, contém níveis aumentados de hidroxiprolina quando comparada a pele normal, dados condizentes com os de Wilgus et al. (2003).

O aumento no conteúdo de colágeno pelo tratamento das úlceras com creme a $10 \%$ de óleo-resina revelou efeito positivo da migração de fibroblastos, células epiteliais e síntese de matriz extracelular, corroborando ao proposto por Kumar et al. (2006).

O colágeno é o principal componente estrutural do tecido de granulação, fortalece e apóia a MEC e, finalmente, irá repor a matriz provisória de fibrinafibronectina. O aminoácido prolina é uma parte integral da fibra de colágeno e a hidroxiprolina é usada como um marcador bioquímico para o colágeno tecidual, assim como um indicativo positivo da progressão da cicatrização (KOKANE et al., 2009; NAYAK et al., 2010).

A presença de fibras de colágeno organizadas e maduras, observadas histopatologia, no grupo tratado com creme a $10 \%$ de óleo-resina, somada ao aumento do conteúdo de hidroxiprolina, sugere a efetividade do óleo-resina de copaíba na proliferação fibroblástica e síntese de MEC durante a cicatrização, propriedades estas, semelhantes às observadas por Araújo et al (2010), relacionadas à utilização do fitoterápico (alantoína) na cicatrização. 
As análises pela zimografia em gelatina indicaram a presença das metaloproteinases de matriz 2 e 9. A MMP-2 está presente normalmente na pele, em níveis basais, enquanto a MMP-9, expressa principalmente por neutrófilos e macrófagos, estaria relacionada à fase inflamatória após uma lesão tecidual (DACHIR et al., 2010; LIU et al., 2009).

A expressão de MMP-9 inicialmente no processo de cicatrização sugere que esta enzima possa estar envolvida na eliminação de tecido necrótico, e pode induzir a migração de queratinócitos e remodelamento do tecido de granulação (ADHIRAJAN et al., 2009). A MMP-9 pode servir para monitorar a fase inflamatória do processo cicatricial, enquanto que a MMP-2 pode ser um marcador de atividade celular do tecido conjuntivo (TARLTON 1999).

As MMPs são necessárias na quantidade certa, no local indicado e em período de tempo específico para que uma úlcera cicatrize de forma satisfatória. Elas desempenham um papel no desbridamento das MECs danificadas/desvitalizadas, na angiogênese, na reepitelização, na contração da úlcera e no remodelamento da cicatriz (BEIDLER et al., 2008; GIBSON et al., 2009).

A atividade da pró-MMP-2 manteve-se praticamente inalterada durante o período de seguimento nas úlceras tratadas com solução fisiológica. Nas úlceras tratadas com creme base houve aumento de atividade do $2^{\circ}$ para 070 dia, seguida de diminuição do $7^{\circ}$ para o $14^{\circ}$ dia. No entanto, as úlceras tratadas com creme a $10 \%$ de óleo-resina apresentaram aumento da atividade proteolítica da pró-MMP-2 durante o seguimento, alcançando no $14^{\circ} \mathrm{dia}$, atividade superior à observada nos grupos controles. Quanto a MMP-2 ativa, houve aumento progressivo durante o seguimento para as úlceras tratadas com solução fisiológica e creme a $10 \%$ de óleo-resina, enquanto para aquelas tratadas com creme base houve aumento do $2^{\circ}$ para o 70 dia e diminuição do 70 para $014^{\circ}$ dia. Esses achados consolidam a atividade cicatrizante do óleo-resina da copaíba, pois confirmam a proposição de que, durante as fases tardias do reparo, um aumento de pró-MMP-2 e a persistência de MMP-2, sugerem que esta enzima tenha uma função importante na fase de remodelamento e também na homeostase do colágeno, conforme trabalhos de Adhirajan et al. (2009); Gupta et al. (2008); Kumar et al. (2006) e Utz et al (2010). 
Alem disso, a maior atividade de pró-MMP-2 nas úlceras tratadas com creme a $10 \%$ de óleo-resina foi coincidente com o aumento do conteúdo de colágeno (hidroxiprolina) durante o seguimento.

Com relação à atividade da MMP-9, enzima relacionada à degradação tardia e cronicidade da úlcera, houve diminuição progressiva durante o período de seguimento para todos os grupos. No $14^{\circ}$ dia nenhuma atividade proteolítica da MMP-9 foi encontrada nas úlceras tratadas com creme a $10 \%$ de óleo-resina, indicando resolução do processo inflamatório, enquanto que nos grupos controles ainda era possível detectar a presença desta enzima, principalmente no grupo que recebeu creme base. Segundo Reiss et al. (2010), em situações onde a inflamação persiste, TNF-a e subsequentemente MMP-9 também persistem e a adesão de queratinócitos à membrana basal recém-sintetizada é prejudicada. Tal fato pode justificar os menores valores de ICU menores que $1 \mathrm{e}$, ainda, o menor conteúdo de hidroxiprolina neste mesmo grupo (creme base).

Embora os modelos animais sejam considerados padrão ouro para a determinação de atividade em muitas áreas de pesquisa, em alguns casos o seu uso pode estar limitado por questões éticas ou regulações governamentais. É importante que se tenham modelos alternativos in vitro.

Alguns estudos na área de cicatrização de úlceras cutâneas utilizam como modelos in vitro, monocamadas de células, como fibroblastos e queratinócitos, assim como co-culturas destes tipos celulares. No entanto, nestes modelos os resultados da avaliação de um produto podem ser limitados, principalmente pelo fato de não serem representações exatas do tecido in vivo devido à falta de interações entre as células e entre as células e a matriz extracelular in vivo. Neste sentido, tem sido proposto o uso de um modelo que utilize cultura de explantes de pele humana, no qual, mesmo representando um modelo ex vivo, a integridade tecidual é preservada, mimetizando a arquitetura tecidual in vivo, com a presença de todas as camadas cutâneas, o que proporciona ao modelo um alto grau de confiabilidade. Tal modelo pode servir como um meio rápido para avaliações bioquímicas e histológicas (BLAUER et al., 2005; GARLICK; TAICHMAN, 1994; JACOBS et al., 2006; LEHÉ et al., 2006; ROYCHOWDHURY et al., 2007; SUNDSTROM et al., 2005).

No intuito de avaliar o óleo-resina de copaíba nesse modelo, foram aplicados, diariamente, óleo-resina de copaíba em sua forma in natura $e$ veiculado em creme nas concentrações de 10 e $25 \%$ nos fragmentos de pele de 
três indivíduos, além dos tratamentos controle com meio de cultura (DMEM) e creme base. Os fragmentos tratados com creme a $10 \%$ de óleo-resina de copaíba e creme base não foram observadas alterações macroscópicas ou histológicas da pele, enquanto nos fragmentos que receberam creme a $25 \%$ de óleo-resina, houve discreto escurecimento a partir do $70 \mathrm{dia}$, enquanto naqueles que receberam o óleo-resina puro, houve escurecimento da pele a partir do 30 dia. O óleo-resina puro, por sua característica lipofílica, pode ter promovido uma barreira física, prejudicando a manutenção das características normais da pele. Nos fragmentos que receberam apenas o meio de cultura, observou-se uma diminuição da hidratação natural da pele, normalmente observado nesse modelo pela cornificação da epiderme primária, a qual é facilmente destacada, porem observa-se uma nova epiderme basal inferiormente, dados confirmados à histologia, os quais demonstraram reepitelização completa das úlceras artificiais ao final do seguimento das culturas no $21^{\circ}$ dia. Em contrapartida, não foram observadas diferenças histológicas entre os grupos tratados.

O modelo foi válido para o estudo da cicatrização (reepitelização), visto que a pele manteve-se viável e proliferativa até o $21^{\circ}$ dia de cultura. Alterações na coloração do meio de cultura foram um indicativo de viabilidade/proliferação celular durante os experimentos.

A aplicação do creme a $10 \%$ de óleo-resina não promoveu reepitelização das úlceras artificiais, diferente do controle apenas com meio de cultura (DMEM), evidenciando que o potencial cicatrizante do óleo-resina de copaíba seja dependente do processo inflamatório, ausente neste modelo. No entanto, alguns efeitos observados pelo uso deste modelo poderiam ser correlacionados com os observados nas úlceras em orelha de coelho tais como as doses aplicadas. Quando aplicou-se o óleo-resina puro nas úlceras em coelhos, este foi extremamente irritante, e nas culturas de pele observou-se o escurecimento dos fragmentos, o que não considera-se normal comparando às características dos fragmentos controle. Este modelo também corroborou com o fato de que a concentração de $25 \%$ de óleo-resina em creme poderia ser alta, observada também pelo rápido escurecimento dos tecidos nesse modelo estéril.

Considerando o perfil de atividade cicatrizante do óleo de copaíba nos modelos in vivo não estéreis, tornou-se indispensável a investigação do seu potencial antimicrobiano. 
Do ponto de vista microbiológico, a função primária da pele normal e intacta é controlar as populações microbianas presentes na superfície cutânea e prevenir que o tecido subcutâneo seja invadido por microrganismos potencialmente patogênicos. A exposição do tecido subcutâneo após a perda de integridade da pele que ocorre quando existe uma úlcera fornece um ambiente que pode ser favorável à infecção. As bactérias, seus metabólitos e as interações bacterianas na úlcera podem prejudicar de maneira significativa o processo normal de cicatrização (BOWLER et al., 2001; SCHMIDT et al., 2009; WALL et al., 2002).

Dentre as inúmeras atividades atribuídas ao óleo-resina de copaíba, sejam popularmente descritas e/ou cientificamente comprovadas, está a atividade antimicrobiana, relacionada principalmente à presença dos compostos sesquiterpênicos (PACHECO; BARATA; DUARTE, 2006; SANTOS et al., 2008b; VALDEVITE, 2007). A maioria dos óleo-resinas de copaíba é composta por uma grande quantidade de sequiterpenos, assim como o óleo-resina utilizado neste estudo, sendo que o composto $\beta$-cariofileno é o principal sesquiterpeno e tem sido descrito por suas atividades antimicrobianas (DEUS et al., 2009; PIERI et al., 2010; SOUSA et al., 2010).

A atividade antimicrobiana de plantas medicinais é frequentemente considerada importante tanto na prevenção quanto no tratamento de infecções de úlceras. Estudos têm mostrado que a atividade antimicrobiana de várias plantas auxilia no processo cicatricial de úlceras (DESHMUKH et al., 2009). Desta forma, buscou-se avaliar a atividade antimicrobiana in vitro do óleo-resina da $C$. langsdorffii frente a cepas padrão de bactérias frequentemente associadas com infecções de úlceras cutâneas na prática clínica: S. aureus, S. pyogenes, E. faecalis, $P$. aeruginosa e E. coli.

Inicialmente, os resultados da atividade antimicrobiana in vitro mostraram que o óleo-resina da $C$. langsdorffii apresentou espectro de inibição somente frente a microrganismos Gram-positivos (S. aureus, S. pyogenes e $E$. faecalis), com valores das concentrações inibitórias mínimas (CIM) de 200, 400 e $1100 \mu \mathrm{g} / \mathrm{mL}$, respectivamente, indicando atividade bacteriostática do óleo-resina nestas concentrações. Os valores das concentrações bactericidas mínimas (CBM) foram os mesmos que os valores de CIM para $S$. aureus e $S$. pyogenes, e de $1200 \mu \mathrm{g} / \mathrm{mL}$ para o $E$. faecalis. Os microrganismos Gram-negativos ( $P$. 
aeruginosa e E. coli) não apresentaram sensibilidade nas concentrações de óleoresina avaliadas.

Esses resultados estão de acordo com estudo de Santos et al. (2008b), que investigaram a atividade antimicrobiana in vitro de diferentes óleo-resinas provenientes da C. martii, C. officinalis e $C$. reticulata em bactérias Grampositivas e Gram-negativas. Os autores encontraram atividade antimicrobiana dos óleo-resinas apenas para bactérias Gram-positivas e nenhuma atividade para as Gram-negativas, relacionando a uma provável ação do óleo-resina na parede celular bacteriana, visto que observaram alterações morfológicas e ultraestruturais quando o óleo-resina foi testado, como rompimento da parede bacteriana e liberação de conteúdo citoplasmático. Cowan (1999), sugere que o mecanismo de ação de terpenos possivelmente envolva o rompimento da parede bacteriana por estes compostos lipofílicos.

Pacheco, Barata e Duarte (2006), também conduziram um estudo de atividade antimicrobiana in vitro de óleo-resinas provenientes de diferentes espécies de copaíba em bactérias Gram-positivas ( $S$. aureus e Bacillus subtilis) e Gram-negativas ( $E$. coli e $P$. aeruginosa). Encontraram inatividade do óleo-resina para todas as amostras testadas em microrganismos Gram-negativos até a concentração de $1000 \mu \mathrm{g} / \mathrm{mL}$ de óleo-resina. Os valores de CIM para os óleoresinas que apresentaram atividade antimicrobiana variaram de $300-550 \mu \mathrm{g} / \mathrm{mL}$ (B. subtilis) e $125-550 \mu \mathrm{g} / \mathrm{mL}$ (S. aureus).

Pieri et al. (2009), investigaram a atividade antimicrobiana in vitro do óleo-resina de copaíba ( $C$. officinalis) e encontraram atividade antimicrobiana sobre os microrganismos orais S. mutans, S. salivarius, S. pyogenes e E. faecalis, confirmando a ação inibitória microbiana possivelmente relacionada à ação germicida de um dos componentes do óleo de copaíba, o $\beta$-cariofileno. Os autores apontam um fato interessante com relação à cepa $S$. pyogenes, que em um ensaio de difusão em ágar, onde se utilizou extrato da casca da copaibeira, não houve inibição do crescimento do microrganismo, sugerindo que a atividade inibitória sobre a referida bactéria é alcançada por componentes presentes apenas no óleo-resina de copaíba, e não na casca da árvore.

Bactérias Gram-positivas e Gram-negativas diferem em suas paredes, onde a parede celular nos microrganismos Gram-negativos representa uma barreira mais resistente que a parede dos Gram-positivos (BEVERIDGE, 1999). O óleo-resina de copaíba parece modificar a parede celular bacteriana, assim, uma 
explicação para a não atividade do mesmo em bactérias Gram-negativas poderia estar relacionada à morfofisiologia complexa da parede destes microrganismos

Não existe um consenso quanto ao nível aceitável de inibição bacteriana para materiais provenientes de plantas medicinais quando comparados a padrões. Duarte et al. (2007), descreveram uma classificação para os resultados de CIM a partir de plantas medicinais, como: até a concentração de $500 \mu \mathrm{g} / \mathrm{mL}$, o material é considerado um forte inibidor; entre 600 e $1500 \mu \mathrm{g} / \mathrm{mL}$, moderado; acima de $1600 \mu \mathrm{g} / \mathrm{mL}$, fraco. Esta classificação foi baseada em testes de produtos de plantas em bactérias provenientes de isolados clínicos.

Outro estudo sugeriu uma classificação baseada na atividade antimicrobiana de compostos naturais em cepas ATCC, sendo que quando os valores de CIM estavam entre 280 e $1270 \mu \mathrm{g} / \mathrm{mL}$, o produto foi considerado ter forte atividade; e quando estavam entre 1810 e $8850 \mu \mathrm{g} / \mathrm{mL}$, fraca atividade (ALIGIANNIS et al. 2001).

Os sesquiterpenos têm sido reportados na literatura como tendo potencial atividade antimicrobiana e desempenham função crítica nos mecanismos de defesa de plantas (TENG et al. 2010). Estes compostos poderiam estar associados às atividades antimicrobianas (bacteriostáticas e bactericidas) observadas no presente estudo quando da atividade antimicrobiana do óleoresina de copaíba contra as bactérias Gram-positivas avaliadas.

Diante do impacto significativo que a presença de infecção pode trazer às úlceras cutâneas, o uso do óleo-resina de copaíba como componente de uma formulação tópica poderia ser um adjunto valioso no tratamento de úlceras infectadas, principalmente nos casos de infecção por microrganismos Grampositivos.

Se um composto designado a promover a cicatrização apresentar atividade antimicrobiana adicional, este pode se tornar uma excelente opção terapêutica, visto que qualquer úlcera pode se tornar infectada, uma vez que a pele é colonizada pelas floras residente e transitória. As interações microbianas podem influenciar a patogênese e a cicatrização das úlceras e podem levar à resistência bacteriana a agentes antimicrobianos. Assim, a avaliação da atividade antimicrobiana in vivo é importante (SHAI; MAIBACH, 2005).

Raros são os dados na literatura sobre estudos do óleo-resina da espécie C. langsdorffii in vitro e em úlceras cutâneas, no entanto, não foi encontrado estudo algum sobre o seu uso em úlceras infectadas, quer seja na avaliação de 
sua atividade antimicrobiana in vivo, quer seja no potencial cicatrizante nestas condições.

Buscou-se então avaliar sua atividade antimicrobiana in vivo em úlceras cutâneas inoculadas com culturas de S. aureus e S. pyogenes, separadamente, e finalmente o estudo do potencial cicatrizante do óleo-resina de copaíba nestas úlceras.

Para confirmar a presença dos microrganismos nas úlceras, foram colhidos swabs 24 horas após a inoculação, e as culturas microbiológicas foram realizadas a partir do material colhido. Todas as amostras avaliadas mostraram crescimento bacteriano e após a contagem das unidades formadoras de colônias, níveis acima daqueles considerados críticos para infecção microbiológica $\left(10^{5}\right.$ $\mathrm{UFC} / \mathrm{mL}$ ) foram encontrados para todos os grupos de avaliação (ERDUR et al., 2008).

A presença de bactérias por si só, não é indicativa de infecção. Entretanto, a possibilidade que uma carga microbiana crítica possa diretamente afetar os resultados da cicatrização tanto em úlceras agudas quanto em úlceras crônicas tem sido considerado por várias décadas, sendo primeiramente demonstrado em 1964 por Bendy e colaboradores, e em 1970 por Robson e Heggers, os quais descreveram que a contagem bacteriana acima de $10^{5}$ UFC por grama de tecido ou $10^{5} \mathrm{UFC} / \mathrm{mL}$ tem efeito deletério na cicatrização em úlceras agudas traumáticas ou cirúrgicas, úlceras crônicas e enxertos cutâneos. Desde então, vários outros trabalhos têm sugerido que este número de bactérias está associado com a não-cicatrização das úlceras (GANATRA; GANATRA, 2007; HOWELL-JONES et al., 2005; STOJADINOVIC et al., 2008). Dados indicam que acima de $10^{5} \mathrm{UFC} / \mathrm{mL}$ as defesas do corpo humano não são capazes de suprimir os microrganismos e a infecção ocorre (DANILLA et al., 2005). Ainda, segundo Landis et al. (2008), a contagem microbiana acima de $10^{5} \mathrm{UFC} / \mathrm{mL}$ nas úlceras tem sido associada com maior incidência de sepse.

Uma vez confirmada a presença dos microrganismos nas úlceras em níveis considerados críticos, indicativos de infecção, realizou-se o seguimento microbiológico das úlceras para avaliar a atividade antimicrobiana in vivo do óleo-resina de copaíba.

De acordo com as culturas por swab a partir das úlceras infectadas com S. aureus, o tratamento com creme a $10 \%$ de óleo-resina de copaíba reduziu a carga bacteriana em $67,3 \%$ no 140 dia de seguimento, comparada ao swab 
inicial (24 horas), enquanto para as úlceras controle solução fisiológica e creme base, a redução da carga bacteriana foi de $18 \%$ e $63,2 \%$, respectivamente. De acordo com as culturas realizadas a partir das biópsias colhidas destas mesmas úlceras, o tratamento com creme a $10 \%$ de óleo-resina reduziu a carga bacteriana em $21,3 \%$ no $14^{\circ}$ dia, comparada ao $2^{\circ}$ dia, enquanto para as úlceras controle tratadas com solução fisiológica e creme base, a redução da carga bacteriana foi de $1,2 \%$ e $17,2 \%$, respectivamente.

De acordo com as culturas por swab a partir das úlceras infectadas com S. pyogenes, o tratamento com creme a $10 \%$ de óleo-resina reduziu a carga bacteriana em $67,5 \%$ no 140 dia de seguimento, comparada ao swab inicial (24 horas), enquanto para as úlceras controle tratadas com solução fisiológica e creme base, a redução da carga bacteriana foi de 39,3\% e 65,3\%, respectivamente. De acordo com as culturas realizadas a partir das biópsias colhidas destas mesmas úlceras, o tratamento com creme a 10\% de óleo-resina reduziu a carga bacteriana em $31,5 \%$ no 140 dia de seguimento, comparada ao $2^{\circ}$ dia, enquanto para as úlceras que receberam solução fisiológica, a redução da carga bacteriana foi de 6,25\%. Houve aumento da carga bacteriana (7,5\%), nas úlceras tratadas com creme base, ao final do seguimento.

A diminuição da carga bacteriana observada nas úlceras que receberam o creme base, parece estar relacionada ao número reduzido de amostra, e não a propriedade do produto, visto que este resultado não foi observado em outras condições como a partir das biópsias para S. pyogenes ou a partir de swabs e biópsias para S. aureus.

A contagem bacteriana foi maior nas culturas realizadas a partir do tecido ulcerado (biópsias) que nas culturas a partir do exsudato (swabs), durante todo o período de seguimento microbiológico das úlceras. Diferenças inerentes às amostras colhidas utilizando swabs e biópsias são esperadas, mesmo porque os ambientes superficial e profundo das úlceras são distintos (SULLIVAN et al., 2004).

Há controvérsias quanto ao melhor método de coleta de material das úlceras cutâneas para a análise do perfil microbiológico como swab da superfície das úlceras e biópsia tecidual (DAVIES et al., 2007). Alguns autores afirmam que a técnica de swab isoladamente falha em fornecer informações com relação à invasão bacteriana no tecido profundo, enquanto outros sugerem que os resultados microbiológicos obtidos por swab da lesão podem adequadamente se 
aproximar aos resultados obtidos por biópsia tecidual (EDWARDS; HARDING, 2004; LANDIS 2008; WARRINER; BURREL, 2005). Ganatra e Ganatra (2007), discutem que as culturas a partir de biópsia das úlceras é o método mais confiável e exato para monitorar a proliferação microbiana e diagnosticar infecção, embora apresente a desvantagem de ser um método invasivo. Alguns autores descrevem as biópsias teciduais como padrão ouro na área de estudos científicos (DAVIES et al., 2007).

Para a avaliação microbiológica das úlceras, o isolamento de bactérias através de cultura a partir de biópsias talvez seja mais relevante em relação à infecção invasiva da úlcera e possível septicemia, que através de cultura a partir da superfície das úlceras (swabs), uma vez que nestes casos a avaliação microbiológica poderia ser influenciada por fatores como a aplicação tópica de agentes antimicrobianos. Entretanto, o melhor procedimento deve ser aquele que se adeque ao propósito da investigação microbiológica, seja esta na rotina clínica, dependente dos sinais e sintomas do paciente e da situação clínica da úlcera, além de custos e disponibilidade de profissionais qualificados; seja nas investigações experimentais em laboratório de pesquisa.

Os resultados in vivo confirmaram os resultados in vitro quanto à atividade antimicrobiana do óleo-resina da C. langsdorffii, visto que a aplicação tópica do creme a $10 \%$ de óleo-resina nas úlceras infectadas tanto com $S$. aureus quanto com $S$. pyogenes diminuiu a carga bacteriana, tanto na superfície quanto no tecido ulcerado, ao final do seguimento. A utilização de produtos que possam agir diretamente no processo de reparo ou indiretamente reduzindo o processo inflamatório e acelerando a cicatrização pelo controle da infecção bacteriana, torna-se um artifício benéfico ao paciente ulcerado (CAVALCANTI NETO et al., 2005).

As úlceras que foram infectadas com $S$. aureus ou $S$. pyogenes e acompanhadas microbiologicamente foram finalmente avaliadas quanto ao potencial cicatrizante do óleo-resina de copaíba nestas condições, ou seja, investigou-se a presença de um possível efeito sinérgico (antimicrobiano tópico e promotor da cicatrização).

No $2^{\circ}$ dia após o procedimento cirúrgico e inoculação das suspensões bacterianas, todas as úlceras apresentavam evidência clínica de infecção local, como presença de exsudato purulento e eritema. Histologicamente observou-se que o infiltrado inflamatório foi intenso nas úlceras tratadas com creme a $10 \%$ 
de óleo-resina e creme base, no mesmo período, estando mais úmidas que aquelas tratadas com solução fisiológica principalmente durante os 3 primeiros dias de seguimento, característica já discutida anteriormente e que pode ser favorável ao processo de reparo pela possibilidade de acelerar a reepitelização (DORNELLES et al., 2003).

No 70 dia, as úlceras infectadas com S. aureus ou S. pyogenes tratadas com creme a $10 \%$ de óleo-resina já não mais apresentavam eritema e as áreas ulceradas estavam menores, evidenciando melhor perfil de reepitelização, além de apresentar melhor fibrogênese à histologia. Ao final do seguimento todas as úlceras tratadas com creme a $10 \%$ de óleo-resina estavam reepitelizadas, e algumas úlceras tratadas com solução fisiológica e creme base ainda não. No 140 dia, as úlceras tratadas com creme a $10 \%$ de óleo-resina mostraram melhor perfil de cicatrização, tanto clinicamente pelos ICUs superiores aos demais grupos, quanto pelos achados histológicos.

O aumento na contração das úlceras tratadas com creme a $10 \%$ de óleoresina de copaíba pode ser devido à atividade aumentada de fibroblastos e à eliminação de bactérias pelo óleo-resina, talvez pela atividade antimicrobiana associada ao constituinte sesquiterpênico $\beta$-cariofileno. A taxa mais lenta de fechamento das úlceras dos grupos controles poderia ser atribuída à presença de microrganismos e seus metabólitos, os quais inibem a contração da úlcera e prejudicam a cicatrização (KUMAR et al., 2008).

De acordo com Sasidharan et al. (2010), os terpenos são conhecidos por promover a cicatrização de úlceras principalmente devido às suas propriedades adstringentes e antimicrobianas, as quais parecem ser responsáveis pela contração da úlceras e taxa de reepitelização aumentada. A propriedade cicatrizante poderia estar atribuída às suas atividades individuais dos terpenos ou ao efeito sinérgico de moléculas bioativas, conforme descrito por Gupta et al. (2008).

Com relação aos parâmetros bioquímicos, o óleo-resina de copaíba parece modular o conteúdo colagênico e a atividade das MMPs mesmo na presença de infecção. Nas úlceras infectadas com $S$. aureus, embora tenhamos observado aumento de atividade da MMP-2 ativa no 70 dia de seguimento, esta atividade estava discretamente reduzida ao final do seguimento, sem diferenças aparentes entre os grupos. De maneira interessante, o conteúdo de colágeno (hidroxiprolina) também foi semelhante para todos os grupos ao final do 
experimento, embora tenhamos observado aumento progressivo durante todo o período.

Nas úlceras infectadas com $S$. pyogenes houve aumento progressivo da atividade da MMP-2 ativa durante o período de seguimento. No 140 dia a atividade da MMP-2 ativa foi maior para as úlceras tratadas com creme a $10 \%$ de óleo-resina, assim como o conteúdo de colágeno (hidroxiprolina), o que demonstra a participação das metaloproteinases no processo de remodelamento e, também, na manutenção da homeostase do colágeno como descrito por Adhirajan et al. (2009); Gupta et al.(2008); Kumar et al. (2006) e Utz et al.(2010).

Com relação à atividade da MMP-9, resultados semelhantes e positivos foram observados no $14^{\circ}$ dia, com ausência de atividade desta enzima (úlceras infectadas com $S$. aureus) e redução de atividade a baixos níveis (úlceras infectadas com S. pyogenes) com a aplicação do creme a $10 \%$ de óleo-resina, indicando redução do processo inflamatório.

Conforme a úlcera cicatriza, a expressão de MMP-9 diminui, sendo o desaparecimento de MMP-9 à resolução do estado patológico (HAN; YAN; GARNER, 2008; RAYMENT; UPTON; SHOOTER, 2008; REISS et al., 2010). A expressão de MMP-9 inicialmente no processo de cicatrização sugere que esta enzima possa estar envolvida na eliminação de tecido necrótico e pode induzir o remodelamento do tecido de granulação e a migração de queratinócitos (ADHIRAJAN et al., 2009).

Os resultados do presente estudo sugerem que o óleo-resina da Copaifera langsdorffii quando incorporado em creme na concentração de $10 \%$ não afeta adversamente o tecido cutâneo, parece ter promovido a cicatrização pelo seu potencial antiinflamatório, o que acelerou a progressão das úlceras para as fases subsequentes do processo cicatricial, além da regulação da expressão das metaloproteinases e aumento do conteúdo de hidroxiprolina. No modelo de úlceras infectadas, observou-se um efeito sinérgico do óleo-resina, visto que o mesmo promoveu a diminuição na carga microbiana nas úlceras, assim como, sua mais rápida e melhor cicatrização. 


\section{Conclusões}

"O sucesso nasce do querer, da determinação e persistência em se chegar a um objetivo. Mesmo não atingindo o alvo, quem busca e vence obstáculos, no mínimo fará coisas admiráveis". José de Alencar 


\section{CONCLUSÕES}

O óleo-resina da Copaifera langsdorffii não apresentou toxicidade aos fibroblastos 3T3 até a concentração de $100 \mu \mathrm{g} / \mathrm{mL}$;

O óleo-resina de copaíba promoveu melhor cicatrização no modelo de úlcera cutânea em orelha de coelho na concentração de $10 \%$, estimulando a fibroplasia, reepitelização e remodelamento das úlceras, enquanto, na sua forma in natura, mostrou-se irritante ocasionando grave agressão tecidual;

O óleo-resina de copaíba a 10\% em creme promoveu a cicatrização no modelo de úlcera cutânea na região dorsal de ratos, estimulando a contração, acelerando a reepitelização, além do estímulo da colagênese (aumento do conteúdo de hidroxiprolina) e da regulação de metaloproteinases de matriz 2 e 9;

$>$ O óleo-resina de copaíba parece modular a fase inflamatória do processo de cicatrização, assim como favorecer as fases tardias de reepitelização e remodelamento, via participação na colagênese e nas atividades das metaloproteinases de matriz 2 e 9;

$>0$ modelo ex vivo de cicatrização da pele humana manteve-se viável por 21 dias de cultura. O óleo-resina de copaíba a 10\% inibiu a reepitelização das úlceras artificiais, diferente do controle apenas com meio de cultura (DMEM), evidenciando que o potencial cicatrizante do óleo é dependente do processo inflamatório, ausente neste modelo; 
$>$ O óleo-resina apresentou atividade antimicrobiana in vitro para os microrganismos Gram-positivos (Staphylococcus aureus, Streptococcus pyogenes e Enterococcus faecalis);

> A aplicação tópica de creme a $10 \%$ de óleo-resina no modelo de úlceras infectadas (com S. aureus ou $S$. pyogenes) em ratos reduziu a carga microbiana tanto na superfície das úlceras quanto no tecido profundo ao final do seguimento (14 dias), assim como beneficiou o processo de cicatrização;

> Enfim, o óleo-resina de copaíba mostrou-se seguro pela não citotoxicidade e eficaz pela atividade antimicrobiana tanto in vitro quanto in vivo em úlceras cutâneas infectadas e pela importante atividade cicatrizante dependente, essencialmente, da fase inflamatória, demonstrada nos modelos de úlceras em orelha de coelho (não retráteis) e no dorso de ratos (retráteis) e ausente no modelo ex-vivo (sem inflamação). 
* De acordo com: "Diretrizes para apresentação de dissertações e teses da Universidade de São Paulo: documento eletrônico e impresso Parte I (ABNT), 2009". 


\section{REFERÊNCIAS}

ABRAHAMS, P.H.; CRAVEN, J.L.; LUMLEY, J.S.P. The structure of the body - the systems and organs. In: University Press, 2005. p.2-20. Illustrated clinical anatomy. New York: Oxford

ABREU, E. S.; MARQUES, M. E. A. Histologia da pele normal. In: JORGE, S. A; DANTAS, S. R. P. E. Abordagem multiprofissional do tratamento de feridas. São Paulo: Atheneu, 2005. p. 17-29.

ADHIRAJAN, N.; SHANMUGASUNDARAM, N.; SHANMUGANATHAN, S.; BABU, M. Collagen-based wound dressing for doxycycline delivery: in-vivo evaluation in an infected excisional wound model in rats. Journal of Pharmacy and Pharmacology, London, v.61, n.12, p.1617-1623, 2009.

ALIGIANNIS, N.; KALPOUTZAKIS, E.; MITAKU, S.; CHINOU, I.B. Composition and antimicrobial activity of the essential oils of two Origanum species. Journal of Agricultural Food Chemistry, Washington, v.49, n.9, p.4168-4170, 2001.

ARAÚJO-JÚNIOR, F.A.; BRAZ, M.N.; ROCHA-NETO, O.G.; D'ALMEIDA COSTA, F.; BRITO, M.V.H. Efeito do óleo de copaíba nas aminotransferases de ratos submetidos à isquemia e reperfusão hepática com e sem pré-condicionamento isquêmico. Acta Cirúrgica Brasileira, São Paulo, v.20, n.1, p.93-99, 2005.

ARAÚJO, L.U.; GRABE-GUIMARÃES, A.; MOSQUEIRA, V.C.F.; CARNEIRO, C.M.; SILVA-BARCELLOS, N.M. Profile of wound healing process induced by allantoin. Acta Cirúrgica Brasileira, São Paulo, v.25, n.5, p.460-466, 2010.

ÁRVORES DO BRASIL, 2010.Disponível em: <www.arvores.brasil.nom.br/copaíba1. jpg>. Acesso em: 29 Mar. 2010.

BAKER, E.A.; KUMAR, S.; MELLING, A.C.; WHETTER, D. Temporal and quantitative profiles of growth factors and metalloproteinases in acute wound fluid after mastectomy. Wound Repair and Regeneration, Saint Louis, v.16, p.95-101, 2008.

BALBINO, C.A.; PEREIRA, L.M.; CURI, R. Mecanismos envolvidos na cicatrização: uma revisão. Brazilian Journal of Pharmaceutical Sciences, São Paulo, v.41, n.1, p.27-51, 2005.

BANDEIRA, M.F.C.L.; OLIVEIRA, M.R.B.; PIZZOLITTO, A.C.; BENATTI NETTO, C. Estudo preliminar da atividade antibacteriana do óleo essencial e da resina da Copaifera multijuga (óleo de copaíba), associados ao óxido de zinco e ao hidrôxido 
de cálcio. Jornal Brasileiro de Clínica e Estética em Odontologia, v.3, n.17, p. 46-51, 1999.

BARTHEL, R.; ABERDAM, D. Epidermal stem cells. Journal of the European Academy of Dermatology and Venereology, Amsterdam, v.19, p. 405-413, 2005.

BAUM, C.L.; ARPEY, C.J. Normal cutaneous wound healing: clinica correlation with cellular and molecular events. Dermatological Surgery, v.31, p.674-686, 2005.

BEANES, S.R.; DANG, C.; SOO, C.; TING, K. Skin repair and scar formation: the central role of TGF- $\beta$. Expert reviews in molecular medicine, Cambridge, v. 5 , p.1-11, 2003.

BEIDLER, S.K.; DOUILLET, C.D.; BERNDT, D.F.; MS; KEAGY, B.A.; RICH, P.B.; MARSTON, W.A. Multiplexed analysis of matrix metalloproteinases in leg ulcer tissue of patients with chronic venous insufficiency before and after compression therapy. Wound Repair and Regeneration, Saint Louis, v.16, p.642-648, 2008.

BELLO, Y.M.; PHILLIPS, T.J. Recent advances in wound healing. Journal of the American Medical Association, Chicago, v.283, n.6, p.716-718, 2000.

BENDY, R. H., NUCCIO, P. A., WOLFE, E., COLLINS, B., TAMBURRO, C., GLASS, W., MARTIN, C.M. Relationship of quantitative wound bacterial counts to healing of decubiti. Effect of topical gentamicin. Antimicrobial Agents and Chemotherapy, Washington, v.4, p.147-55, 1964.

BERG, J.O.; MOSSNER, B.K.; SKOV, M.N.; LAURIDSEN, J.; GOTTRUP, F.; KOLMOS, H.J. Antibacterial properties of EMLAs and lidocaine in wound tissue biopsies for culturing. Wound Repair and Regeneration, Saint Louis, v.14, p.581-585, 2006.

BEVERIDGE, T.J. Structures of Gram-negative cell walls and their derived membrane vesicles. Journal of Bacteriology, Washington, v.181, n.16, p.4275-4733, 1999.

BLAUER, M.; HEINONEN, P.K.; MARTIKAINEN, P.M.; TOMAS, E.; YLIKOMI, T. A novel organotypic culture model for normal human endometrium: regulation of epithelial cell proliferation by estradiol and medroxyprogesterone acetate. Human Reproduction, Oxford, v.20, n.4 p. 864-871, 2005.

BOWLER, P.G.; DUERDEN, B.I.; ARMSTRONG, D.G. Wound microbiology and associated approaches to wound management. Clinical Microbiological Reviews, v.14, 244-269, 2001. 
BRANDÃO, G.L.; ZANETTI, N.N.S.; OLIVEIRA, P.; GRAEL, C.F.F.; SANTOS, A.C.P.; MONTE-MÓR, R.L.M. Brazilian medicinal plants described by 19 th century European naturalists and in the Official Pharmacopoeia. Journal of Ethnopharmacology, Limerick, v.120, 141-148, 2008.

BRITO, N.M.B.; SIMÕES, M.J.; GOMES, P.O.; PESSOA, A.F.O; MELO, M.C.F. Aspectos microscópicos da cicatrização de feridas cutâneas abertas tratadas com óleo de copaíba em ratos. Revista Paraense de Medicina, Belém, v.13, n.1, p.12-17, 1999.

BRITO, N.M.B.; SIMÕES, M.J.; PESSOA, A.F.; ; MELO, M.C.F. Efeitos do óleo de copaíba na cicatrizaçäo de feridas cutâneas abertas em ratos. Revista Paraense de Medicina, Belém, v.12, n.1, p.28-32, 1998.

BROUGHTON II, G.; JANIS, J.E; ATTINGER, C.E. A Brief History of Wound Care. Plastic and Reconstructive Surgery, Baltimore, v.117, p.6S-11S, 2006a.

BROUGHTON II, G.; JANIS, J.E.; ATTINGER, C.E. Wound healing: An overview. Plastic and Reconstructive Surgery, Baltimore, v.117, p.1e-S-32e-S, 2006b.

BUCHANAN, K.; HEIMBACH, D.M.; MINSHEW, B.H.; COYLE, M.B. Comparison of quantitative and semiquantitative culture techniques for burn biopsy. Journal of Clinical Microbiology, Washington, v.23, p.258-261, 1986.

BURD, A.; KWOK, C.H.; HUNG, S.C.; CHAN, H.S.; GU, H.; LAM, W.K.; HUANG, L. A comparative study of the cytotoxicity of silver-based dressings in monolayer cell, tissue explant, and animal models. Wound Repair and Regeneration, Saint Louis, v.15, p.94-104, 2007.

CABRAL, A.L.S. Insuficiência venosa crônica de membros inferiores: prevalência, sintomas e marcadores preditivos. 2000. 140 f. Tese (Doutorado) - Escola Paulista de Medicina, Universidade Federal de São Paulo, São Paulo, 2000.

CAETANO, K.S.; FRADE, M.A.C.; MINATEL, D.G.; SANTANA, L.A.; ENWEMEKA, C.S. Phototherapy improves healing of chronic venous ulcers. Photomedicine \& Laser Surgery, Larchmont, v.27, p.111-118, 2009.

CARVALHO, J.C.T.; CASCON, V.; POSSEBON, L.S.; MORIMOTO, M.S.S.; CARDOSO, L.G.V.; KAPLAN, M.A.C.; GILBERT, B. Topical anti-inflammatory and analgesic activities of Copaifera duckei Dwyer. Phytotherapy Research, London, v.19, 946950, 2005. 
CASCON, V. Copaíba (Copaifera spp.). In: CARVALHO, J.C.T. Fitoterápicos antiinflamatórios - aspectos químicos, farmacológicos e aplicações terapêuticas. São Paulo: Tecmedd editora, 2004. p. 221-256.

CASCON, V.; GILBERT, B. Characterization of the chemical composition of oleoresins of Copaifera guianensis Desf., Copaifera duckei Dwyer and Copaifera multijuga Hayne. Phytochemistry, New York, v.55, p.773-778, 2000.

CAVALCANTI NETO, A.T.; ARRUDA, T.E.P.; ARRUDA, T.T.P PEREIRA, S.L.S.; TURATTI, E. Análise comparativa entre o óleo-resina de copaíba e o digluconato de clorexidina no processo de cicatrização tecidual. Estudo histológico em dorso de ratos. Revista de Odontologia da UNESP, Marília, v.34, n.2, p.107-112, 2005.

CHETTIBI, S.; FERGUSON, M.W.J. Wound repair: an overview. In: Inflammation basic principles and clinical correlates. 3rd ed. Philadelphia: John I. Galhn and Ralph Snyderman, Lippincott Williams \& Wilkins, 1999. p.865-881.

CHENG, X; FANG, H.; XU, W. Advances in assays of matrix metalloproteinases (MMPs) and their inhibitors. Journal of Enzyme Inhibition and Medicinal Chemistry, v.23, n.2, p.154-167, 2008.

CHOUCAIR, M.M.; BELLO, Y.M.; PHILLIPS, T.J. Wound dressings. In: FREEDBERG, M; EISEN, A.Z.; WOLFF, K.; AUSTEN, F.K.; GOLDSMITH, L.A.; KATZ S. Fitzpatrick's Dermatology in General Medicine. 6th ed. New York: McGraw-Hill, 2003. v.2, p.2544-2549.

CLARK, R.A.F.; GHOSH, K.; TONNESEN, M.G. Tissue engineering for cutaneous wounds. Journal of Investigative Dermatology, Baltimore, v.127, p.1018-1029, 2007.

COOPER, R.A.; MOLAN, P.C.; HARDING, K.G. The sensitivity to honey of Grampositive cocci of clinical significance isolated from wounds. Journal of Applied Microbiology, Oxford, v.93, p.857-863, 2002.

CORSETTI, G.; D'ANTONA, G.; DIOGUARDI, F.S.; REZZANI, R. Topical application of dressing with aminoacids improves cutaneous wound healing in aged rats. Acta histochemica, Jena, v.112, n.5, p.497-507, 2009.

COWAN, M.M. Plant Products as Antimicrobial Agents. Clinical Microbiology Reviews, Washington, v.12, n.4, p.564-582, Oct. 1999.

DACHIR, S.; COHEN, M.; FISHBEINE, E.; SAHAR, R.; BRANDIES, R.; HORWITZ, V.; KADAR, T. Characterization of acute and long-term sulphur mustard-induced skin 
injuries in hairless guinea-pigs using non-invasive methods. Skin Research and Technology, Copenhagen, v.16, p.114-124, 2010.

DANILLA, S.; ANDRADES, P.; GÓMEZ, M.E.; CHAMORRO, M.; LENIZ, P.; PIÑEROS, J.L.; LLANOS, S.; ROCO, H.; CORREA, G.; PASTEN, J.A.; EULUFI, A.; ROA, R.; CALDERON, W. Concordance between qualitative and quantitative cultures in burned patients. Analysis of 2886. Burns, Guildford, v.31, p.967-971, 2005.

DATTNER, A.M. From medical herbalism to phytotherapy in dermatology: back to the future. Dermatologic Therapy, Copenhagen, v.16, p.106-113, 2003.

DAVIES, C.E.; HILL, K.E.; NEWCOMBE, R.G.; STEPHENS, P.; WILSON, M.J.; HARDING, K.G.; THOMAS, D.W. A prospective study of the microbiology of chronic venous leg ulcers to reevaluate the clinical predictive value of tissue biopsies and swabs. Wound Repair and Regeneration, Saint Louis, v.15, 17-22, 2007.

DESHMUKH, P.T.; FERNANDES, J.; ATUL, A.; TOPPO, E. Wound healing activity of Calotropis gigantea root bark in rats. Journal of Ethnopharmacology, Limerick, v.125, p.178-181, 2009.

DEUS, R.J.A.; CARVALHO, A.S.C.; BANNA, D.A.D.S.; ARRUDA, M.S.P.; ALVES, C.N.; SANTOS, A.S. Efeito fungitóxico in vitro do óleo resina e do óleo essencial de copaíba (Copaifera multijuga Hayne). Revista Brasileira de Plantas Medicinais, Botucatu, v.11, n.3, p.347-353, 2009.

DIEGELMANN, R.F.; EVANS, M.C. Wound healing: an overview of acute, fibrotic and delayed healing. Frontiers in Bioscience, Tampa, v.9, p.283-289, 2004.

DORNELLES, D.; WOUK, A.F.; PONTAROLO, R.;OLIVEIRA, A.B. Efeito de aloe vera linné sobre a cicatrização de feridas de pele em coelhos. Visão Acadêmica, Curitiba, v.4, n.1, p.39-46, 2003.

DOUGHTY, D.B; SPARKS-DeFRIESE, B. Wound healing physiology. In: BRYANT, R.A.; NIX, D.P. Acute and chronic wounds. Current management concepts. 4th ed. Missouri: Elsevier Mosby, 2012. cap.4, p.63-82.

EDWARDS, C.A.; O'BRIEN, W.D. Modified assay for determination of hydroxyproline in a tissue hydrolyzate. Clinica Chimica Acta, Amsterdam, v.104, p. 161-167, 1980.

EDWARDS, R; HARDING, K.G. Bacteria and wound healing. Current Opinion in Infectious Diseases, London, v.17, p.91-96, 2004. 
EDWARDS, S.L. Innate Defences. In: MONTAGE, S.E.; WATSON, R.; HERBERT, R.A. Physiology for nursing practice. 3rd ed. Spain: Elsevier, 2005. p.635-683.

ENOCH, S.; LEAPER, D.J. Basic science of wound healing. Surgery, Saint Louis, v.23, n.2, p.37-42, 2005.

ERDUR, B.; ERSOY, G.; YILMAZ, O.; OZKUTUK, A.; SIS, B.; KARCIOGLU, O.; PARLAK, I.; AYRIK, C.; AKSAY, E.; GURYAY, M. A Comparison of the prophylactic uses of topical mupirocin and nitrofurazone in murine crush contaminated wounds.

American Journal of Emergency Medicine, Philadelphia, v.26, p.147-153, 2008.

FERNANDES, F.F.; FREITAS, E.P.S. Acaricidal activity of an oleoresinous extract from Copaifera reticulata (Leguminosae: Caesalpinioideae) against larvae of the southern cattle tick, Rhipicephalus (Boophilus) microplus (Acari: Ixodidae). Veterinary Parasitology, Amsterdam, v.147 p.150-154, 2007.

FRADE, M.A.C.; CURSI, I.G.; ANDRADE, F.F.; CASEMIRO, S.S.; RIBEIRO, W.S.; SANTOS, S.V.; FOSS, N.T. Úlcera de perna: um estudo de casos em Juiz de Fora-MG (Brasil) e região. Anais Brasileiros de Dermatologia, Rio de Janeiro, v.80, n.1, p.41-46, 2005.

FRADE, M.A.C. Úlcera de perna: caracterização clínica e perfil imunohistopatológico da cicatrização na presença da biomembrana de látex natural da seringueira Hevea brasiliensis. 2003. 164 f. Tese (Doutorado) Faculdade de Medicina de Ribeirão Preto, Universidade de São Paulo, Ribeirão Preto, 2003.

FRANTZ, R.A. Identifying infection in chronic wounds. Nursing, London, p.76, 2005.

GABRIELSON, J.; HART, M.; JARELOV, A. Evaluation of redox indicators and the use of digital scanners and spectrophotometer for quantification of microbial growth in microplates. Journal of Microbiological Methods, Amsterdam, v.50, p.63-73, 2002.

GANATRA, M.A.; GANATRA, H.A. Method of quantitative bacterial count in burn wound. Pakistan Journal of Medical Sciences, v.23, n.3, p.415-419, 2007.

GARLICK, J.A.; TAICHMAN, L.B. Effect of TGF- $\beta$ on reepithelialization of human keratinocytes in vitro: an organotypic model. Journal of Investigative Dermatology, Baltimore, v.103, p.554-559, 1994.

GEER, D.J.; SWARTZ, D.D.; ANDREADIS, S.T. In vivo model of wound healing based on transplanted tissue-engineered skin. Tissue Engineering, v.10,n.7/8, p.10061017, 2004. 
GIBSON, D.; CULLEN, B.; LEGERSTEE, R.; HARDING, K.G.; SCHULTZ, G. MMPs Made Easy. Wounds International 2009; v.1, n.1: Disponível em http://www. woundsinternational.com

GILL, S.E.; PARKS, W.C. Metalloproteinases and their inhibitors: regulators of wound healing. The International Journal of Biochemistry and Cell Biology, v.40, p.1334-1347, 2008.

GOMES, N.M.; REZENDE, C.M.; FONTES, S.P.; MATHEUS, M.E.; FERNANDES, P.D. Antinociceptive activity of Amazonian copaiba oils. Journal of Ethnopharmacology, Limerick, v.109, 486-492. 2007.

GRAAF, K.M.V.; FOX, S.I. Integumentary system. In: Concepts of human anatomy and physiology. 2nd ed. Iowa: WM. C. Brown Publishers, 1989. p.178203.

GUPTA, A.; UPADHYAY, N.K.; SAWHNEY, R.C.; KUMAR, R. A poly-herbal formulation accelerates normal and impaired diabetic wound healing. Wound Repair and Regeneration, Saint Louis, v.16, p.784-790, 2008.

GURTNER, G.C.; WERNER, S.; BARRANDON, Y.; LONGAKER, M.T. Wound repair and regeneration. Nature, London, v.453, n.15, 314-321, 2008.

HABIF, T.P. Principles of diagnosis and anatomy. In: Clinical Dermatology: a color guide to diagnosis and therapy. 3rd ed. Missouri: Von Hoffman Press, 1996. p.1-24.

HALLORAN, CM; SLAVIN, JP. Pathophysiology of wound healing. Surgery, Saint Louis, v.20, n.5, p.i-v, 2002.

HAN, Y.P.; YAN, C.; GARNER, W.L. Proteolytic activation of matrix metalloproteinase9 in skin wound healing is inhibited by alpha-1-antichymotrypsin. Journal of Investigative Dermatology, Baltimore, v.128, n.9, p.2334-2342, 2008.

HARDING, K.G.; PATEL, M.G.K. Science, medicine and the future: Healing chronic wounds. British Medical Journal, London, v.324, p.160-163, 2002.

HOWELL-JONES, R.S.; WILSON, M.J.; HILL, K.E.; HOWARD, A.J.; PRICE, P.E.; THOMAS, D.W. A review of the microbiology, antibiotic usage and resistance in chronic skin wounds. Journal of Antimicrobial Chemotherapy, London, v.55, p.143-149, 2005. 
HU, X.; BEETON, C. Detection of functional matrix metalloproteinases by zymography. Jornal of Visualized Experiments. http://www.jove.com/index/ Details.stp?ID=2445, 2010.

INOMATA, S.; MATSUNAGA, Y.; AMANO, S.; TAKADA, K.; KOBAYASHI, K.; TSUNENAGA, M.; NISHIYAMA, T.; KOHNO, Y.; FUKUDA, M. Possible involvment of gelatinases in basement membrane damage and wrinkle formation in chronically ultraviolet B-exposed hairless mouse. Journal of Investigative Dermatology, Baltimore, v.120, p.1-7, 2003.

JACOBS, J.J.L; LEHÉ, C.; CAMMANS, K.D.A.; DAS, P.K.; ELLIOT, G.R. An in vitro model for detecting skin irritants: methyl green-pyronine staining of human skin explants cultures. Toxicology in Vitro, New York, v.16, p.581-588, 2002.

JAUL, E. Non-healing wounds: The geriatric approach. Archives of Gerontology and Geriatrics, Amsterdam, v.49, p.224-226, 2009.

JUDE, E.B.; BLAKYTNY, R.; BULMER, J.; BOULTON, A.J.; FERGUSON, M.W. Transforming growth factor-beta 1, 2, 3 and receptor type I and II in diabetic foot ulcers. Diabetic Medicine, Chichester, v.19, n.6, p.440-447, 2002.

KARUKONDA, S.R.K.; FLYNN, T.C.; BOH, E.E.; McBURNEY, E.I.; RUSSO, G.; MILIKAN, L.E. The effects of drugs on wound healing: part 1. International Journal of Dermatology, Philadelphia, v.39, p. 250-257, 2000.

KLOTH, L.C.; MCCULLOCH, J.M. The inflammatory response to wounding. In: MCCULLOCH, J.M.; KLOTH, L.C.; FEEDAR, J.A. Wound Healing: Alternatives in Management, 2nd ed. Philadelphia: Davis, 1995. p.3-15.

KONIG M, PESCHEN, M.; VANSCHEIDT W. Molecular biology of chronic wound. In: HAFNER J, RAMELET, A.A.; SCHEMELLER, W.; BRUNNER, U.V. Current problems in dermatology. Management of leg ulcers. Basel: Karger, 1999. v.27, p.8-12.

KOKANE, D.D.; MORE, R.Y.; KALE, M.B.; NEHETE, M.N.; MEHENDALE, P.C.; GADGOLI, C.H. Evaluation of wound healing activity of root of Mimosa pudica. Journal of Ethnopharmacology, Limerick, v.124, p.311-315, 2009.

KUMAR, M.S.; KIRUBANANDAN, S.; SRIPRIYA, R.; SEHGAL, P.K. Triphala promotes healing of infected full-thickness dermal wound. Journal of Surgical Research, New York, v.144, p.94-101, 2008.

KUMAR, M.S.; SRIPRIYA, R.; RAGHAVAN, H.V.; SEGHAL, P.K. Wound healing potential of Cassia fistula on infected albino rat model. Journal of Surgical Research, New York, v.131, p. 283-289, 2006. 
KUPAI, K.; SZUCS, G.; CSEH, S.; HAJDU, I.; CSONKA, C.; CSONT, T.; FERDINANDY, $P$. Matrix metalloproteinase activity assays: Importance of zymography. Journal of Pharmacological and Toxicological Methods, New York, v.61, p.205-209, 2010.

LADWIG, G.P.; ROBSON, M.C.; LIU, R.; KUHN, M.A.; MUIR, D.F.; SCHULTZ, G.S. Ratios of activated matrix metalloproteinase-9 to tissue inhibitor of matrix metalloproteinase-1 in wound fluids are inversely correlated with healing of pressure ulcers. Wound Repair and Regeneration, Saint Louis, v.10, p.26-37, 2002.

LANDIS, S.J. Chronic wound infection and antimicrobial use. Advances in Skin \& Wound Care, Springhouse, v.21, p.531-40, 2008.

LAUER, G.; SOLLBERG, S.; COLE, M.; FLAMME, I.; STÜRZEBECHER, J.; MANN, K.; KRIEG, T.; EMING, S.A. Expression and proteolysis of vascular endothelial growth factor is increased in chronic wounds. Journal of Investigative Dermatology, Baltimore, v.115, n.1, p.12-18, 2000.

LEHÉ, C.L.; JACOBS, J.J.L.; HUA, C.M.; COURTELLEMONT, P.; ELLIOTT, G.R.; DAS, P.K. Subtoxic concentrations of allergenic haptens induce LC migration and maturation in a human organotypic skin explant culture model: a novel method for identifying potential contact allergens. Experimental Dermatology, Copenhagen, v.15, p.421-431, 2006.

LIBANORE, D.Z. Efeitos da terapia a laser de baixa intensidade (685 e 830 nm) na taxa de proliferação bacteriana e na cicatrização de feridas cutâneas em modelo animal. 2008. 94 f. Dissertação (Mestrado) - Interunidades em Bioengenharia - EESC/FMRP/IQSC, Universidade de São Paulo, São Carlos, 2008.

LIMA E COSTA, M.F.; GUERRA, H.L.; BARRETO, S.M.; GUIMARÃES, R.M. Diagnóstico da situação de saúde da população idosa brasileira: um estudo da mortalidade e das internações hospitalares públicas. Informe Epidemiológico do SUS, v.9, n.1, p. 23-41, 2000.

LIMA SILVA, J.J.; GUIMARÃES, S.B.; SILVEIRA, E.R.; VASCONCELOS, P.R.L.; LIMA, G.G.; TORRES, S.M.; VASCONCELOS, R.C. Effects of Copaifera langsdorffii Desf. on ischemia-reperfusion of randomized skin flaps in rats. Aesthetic Plastic Surgery, New York, v.33, p.104-109, 2009.

LIMA, S.R.M.; VEIGA JUNIOR, V.F.; CHRISTO, H.B.; PINTO, A.C.; FERNANDES, P.D. In vivo and in vitro studies on the anticancer activity of Copaifera multijuga Hayne and its fractions. Phytotherapy Research, London, v.17, p.1048-1053, 2003.

LIU, Y.; MIN, D.; BOLTON, T.; NUB 'E, V.; TWIGG, S.M.; YUE, D.K.; MCLENNAN, S.V. Increased matrix metalloproteinase- 9 predicts poor wound healing in diabetic foot ulcers. Diabetes Care, Alexandria, v.32, p.117-119, 2009. 
LOBMANN, R.; AMBROSCH, A.; SCHULTZ, G.; WALDMANN, K.; SCHIWECK, S.; LEHNERT, $H$. Expression of matrix-metalloproteinases and their inhibitors in the wounds of diabetic and non-diabetic patients. Diabetologia, Berlin, v.45, p.10111016, 2002.

LOMBARD, C.; SAULNIER, J.; WALLACH, J. Assays of matrix metalloproteinases (MMPs) activities: a review. Biochimie, Paris, v.87, p.265-272, 2005.

MAFFEI, F.H.A. Varizes de membros inferiores: epidemiologia, etiopatogenia e fisiopatogenia. In: MAFFEI, F.H.A.; ROLLO, H.A.; LASTÓRIA, S.; YOSHIDA, W.B. (Org.). Doenças Vasculares Periféricas. 3.ed. Rio de Janeiro: MEDSI - Editora Médica e Científica Ltda, 2002. v.2, p.1499-1510.

MANDELBAUM, S.H.; DI SANTIS, E.P.; MANDELBAUM, M.H.S. Cicatrização: conceitos atuais e recursos auxiliares - Parte 1. Anais Brasileiros de Dermatologia, Rio de Janeiro, v.78, n.4, p.393-410, 2003.

MANKAD, P.S.; CODISPOTI, M. The role of fibrin sealants in hemostasis. The American Journal of Surgery, v.182, 21S-28S, 2001.

MARTIN, V. The skin. In The human body. The essential illustrated reference. Spain: Davids \& Charles, 2005. p.18-21.

MENDONÇA, D.E.; ONOFRE, S.B. Atividade antimicrobiana do óleoresina produzido pela copaíba - Copaifera multijuga Hayne (Leguminosae). Revista Brasileira de Farmacognosia, São Paulo, v.19, p.577-581, 2009.

MENDONÇA, F. A.C.; K.F.S. SILVA; K.K. SANTOS; RIBEIRO-JUNIOR, K.A.L.; SANT'ANA, A.E.G Activities of some Brazilian plants against larvae of the mosquito Aedes aegypti. Fitoterapia, Milano, v.76, p.629- 636, 2005.

MENKE, M.N.; MENKE, N.B.; CECELIA H. BOARDMAN, C.H. ROBERT F. DIEGELMANN, R.F. Biologic therapeutics and molecular profiling to optimize wound healing. Gynecologic Oncology, New York, v.111 p.S87-S91, 2008.

MENKE, N.B; WARD, K.R.; WITTEN, T.M.; BONCHEV, D.G.; DIEGELMANN, R.F. Impaired wound healing. Clinics in Dermatology, Philadelphia, v.25, p.19-25, 2007.

MINATEL, D.G.; FRADE, M.A.C; FRANCA, S.; ENWEMEKA, C.S. Phototherapy promotes healing of chronic diabetic leg ulcers that failed to respond to other therapies. Lasers in Surgery and Medicine, New York, v.41, p.433-441, 2009. 
MONACO, J.L.; LAWRENCE, T. Acute wound healing an pverview. Clinics in Plastic Surgery, Philadelphia, v.30, p.1-12, 2003.

MONTES, L.V.; BROSEGHINI, L.P.; ANDREATTA, F.S.; SANT'ANNA, M.E.S.; NEVES, V.M; SILVA, A.G. Evidências para o uso da óleo-resina de copaíba na cicatrização de ferida - uma revisão sistemática. Natureza on line, v.7, n.2, p.61- 67 [on line], 2009.

MUSTOE, T.A.; PIERCE, G.F.; MORISHIMA, C.; DEUEL, T.F. Growth Factor-induced acceleration of tissue repair through direct and inductive activities in a rabbit dermal ulcer model. Journal of Clinical Investigation, New York, v.87, p. 694-703, 1991.

NARDI, A.B.; RODASKI, S.; SOUSA, R.S.; BAUDI, D.L.K.; CASTRO, J.H.T. Cicatrização secundária em feridas dermoepidérmicas tratadas com ácidos graxos essenciais, vitaminas a e e, lecitina de soja e iodo polivinilpirrolidona em cães. Archives of Veterinary Science, v.9, n.1, p.1-16, 2004.

NAYAK, B.S.; KANHAI, J.; MILNE, D.M.; PEREIRA, L.P.; SWANSTON, W.H. Experimental evaluation of ethanolic extract of Carapa guianensis L. leaf for its wound healing activity using three wound models. Evidence-based complementary and alternative medicine (eCAM), Oxford, p.1-7, 2009.

OPDYKE, D. L. J. Monographs on Fragrance Raw Materials. Food and Cosmetic Toxicology, v.11, p. 1011-1081, 1973.

PACHECO, T.A.R.C.; BARATA, L.E.S.; DUARTE, M.C.T. Antimicrobial activity of copaiba (Copaifera spp) balsams. Revista Brasileira de Plantas Medicinais, Botucatu, v.8, n.esp., p.123-124, 2006.

PAIVA, L.A.F., CUNHA, K.M.A., SANTOS, F.A., GRAMOSA, N.V., SILVEIRA, E.R., RAO, V.S.N. Investigation on the wound healing activity of oleoresin from Copaifera langsdorffii in rats. Phytotherapy Research, London, v.16, 737-739, 2002.

PAIVA, L.A.F.; RAO, V.S.N.; GRAMOSA, N.V.;SILVEIRA, E.R. Gastroprotective effect of Copaifera langsdorffii oleo-resin on experimental gastric ulcer models in rats. Journal of Ethnopharmacology, Limerick, v.62, p.73-78, 1998.

PATTANAYAK, S.P.; SUNITA, P. Wound healing, anti-microbial and antioxidant potential of Dendrophthoe falcata (L.f) Ettingsh. Journal of Ethnopharmacology, Limerick, v.120, p.241-247, 2008.

PHILLIPS, T.J.; DOVERS, J.S. Leg Ulcers. Journal of the American Academy of Dermatology, Saint Louis, v.25, p.965-987, 1991. 
PIERI, F.A.; MUSSI, M.C.; MOREIRA, M.A.S. Óleo de copaíba (Copaifera sp.): Histórico, extração, aplicações industriais e propriedades medicinais. Revista Brasileira de Plantas Medicinais, Botucatu, v.11, n.4, p.465-472, 2009.

PLOWDEN, C. Notes on economic plants. Economic Botany, v.58, n.4, p.729-739, 2004.

RAMOS, M.F.S. Desenvolvimento de microcápsulas contendo a fracão volátil de copaíba por spray-drying: estudo de estabilidade e avaliação farmacológica. 2006. 132 f. Tese (Doutorado) - Faculdade de Ciências Farmacêuticas de Ribeirão Preto Universidade de São Paulo, Ribeirão Preto, 2006.

RAO, C.N.; LADIN, D.A.; LIUY, Y.; CHILUKURI, K.; HOU, Z.Z.; WOODLEY, D.T. Alpha 1 antitrypsin is degraded and non-functional in chronic wounds but intact and functional in acute wounds: the inhibitor protects fibronectin from degradation by chronic wound fluid enzymes. Journal of Investigative Dermatology, Baltimore, v.105, p.572-78, 1995.

RAYMENT, E.A.; UPTON, Z.; SHOOTER, G.K. Increased matrix metalloproteinase-9 (MMP-9) activity observed in chronic wound fluid is related to the clinical severity of the ulcer. British Journal of Dermatology, London, v.158, p.951-961, 2008.

REDDY, B.S.; REDDY, R.K.K.; NAIDU, V.G.M.; MADHUSUDHANA, K.; AGWANE, S.B.; RAMAKRISHNA, S.; DIWAN, P.V. Evaluation of antimicrobial, antioxidant and woundhealing potentials of Holoptelea integrifolia. Journal of Ethnopharmacology, Limerick, v.115, p.249-256, 2008.

REDDY, G.K.; ENWEMEKA, C.S. A simplified method for the analysis of hydroxyproline in biological tissues. Clinical Biochemistry, Toronto, v.29, n.3, 225229, 1996.

REHDER, J.; SOUTO, L.R.M.; BERNARDINO, C.M.; ISSA, M. PUZZI, M.B. Model of human epidermis reconstructed in vitro with keratinocytes and melanocytes on dead de-epidermized human dermis. São Paulo Medical Journal, São Paulo, v.122, n.1, p.22-25, 2004.

RIGAMONTTE-AZEVEDO, O.C.; WADT, P.G.S.; WADT, L.H.O.; VEIGA JUNIOR, V.F.; PINTO, A.C.; REGIANI, A.M. Variabilidade química e física do óleo-resina de Copaifera spp. no Sudoeste da Amazônia Brasileira. Revista Brasileira de oleagenosas e fibrosas, v.8, n.2/3, p.851-861, 2004.

ROBSON, M.C.; HEGGERS, J. Delayed wound closures based on bacterial counts. Journal of Surgical Oncology, New York, v.2, p. 379-383, 1970. 
ROLDÁN-MARÍN, R.; CONTRERA-RUIZ, J.; ARENAS, R.; VAZQUEZ-DEL-MERCADO, E.; CAIRE-TOUSSANIT; MEMIJE-VEGA, ME. Fixed sporotrichosis as a cause of a chronic ulcer on the knee. International Wound Journal, Oxford, v.6, n.1, p.6366, 2009.

ROLSTAD, B.S.; BRYANT, R.A.; NIX, D.P. Topical Management. In: BRYANT, R.A.; NIX, D.P. Acute and chronic wounds. Current management concepts. 4th ed. Missouri: Elsevier Mosby, 2012. cap.18, p.289-306.

ROYCHOWDHURY, S.; CRAM, A.E.; ALY, A.; SVENSSON, C.K. Detection of haptenated proteins in organotypic human skin explant cultures exposed to dapsone. Drug metabolism and disposition, Switzerland, v.35, n.9, 2007.

SALVADOR, S.L.; MASSON, D.S.; FRADE, M.A.C. Antimicrobial Activity of Copaifera langsdorffii Oleoresin on Streptococcal Species. Journal of Dental Research, Alexandria, v.87, Special Issue, p.108, 2008.

SANTOS, A.O.; UEDA-NAKAMURA, T.; DIAS FILHO, B.P.; VEIGA JÚNIOR, V.F.; PINTO, A.C., NAKAMURA, C.V. Effect of Brazilian copaiba oils on Leishmania amazonensis. Journal of Ethnopharmacology, Limerick, v.120, p.204-208, 2008a.

SANTOS, A.O.; UEDA-NAKAMURA, T.; DIAS FILHO, B.P.; VEIGA JÚNIOR, V.F.; PINTO, A.C.; NAKAMURA, C.V. Antimicrobial activities of Brazilian copaíba oils obtained from different species of the Copaifera genus. Memórias do Instituto Oswaldo Cruz, Rio de Janeiro, v.103, p.277-281, $2008 \mathrm{~b}$.

SCHMIDT, C.; FRONZA, M.; GOETTERT, M.; GELLER, F.; LUIK, S.; FLORES, E.M.M.; BITTENCOURT, C.F.; ZANETTI, G.D.; HEINZMANN, B.M.; LAUFER, S.; MERFORT, I. Biological studies on Brazilian plants used in wound healing. Journal of Ethnopharmacology, Limerick, v.122, n.3, p.523-532, 2009.

SHAI, A; MAIBACH, H.I. Antibiotics, antiseptics and cutaneous ulcers. In:

Wound healing and ulcers of the skin. Diagnosis and Therapy - the pratical approach. Germany: Springer, 2005. p.135-150.

SHIVHARE, Y.; SINGOUR, P.K.; PATIL, U.K.; PAWAR, R.S. Wound healing potential of methanolic extract of Trichosanthes dioica Roxb (fruits) in rats. Journal of Ethnopharmacology, Limerick,v.127, p.614-19, 2010.

SCHULTZ, G.S. Molecular and cellular regulators . In: BRYANT, R.A.; NIX, D.P. Acute and chronic wounds. Current management concepts. 4th ed. Missouri: Elsevier Mosby, 2012. cap.20, p.324-336. 
SCHULTZ, G.S.; DAVIDSON, J.M.; KIRSNER, R.S.; BORNSTEIN, P.; HERMAN, I.M. Dynamic reciprocity in the wound microenvironment. Wound Repair and Regeneration, Saint Louis, v.19, p.134-148, 2011.

SILVA, H.H.G; GERIS, R.; RODRIGUES-FILHO, E.; ROCHA, C.; SILVA, I.G. Larvicidal activity of oil resin fractions from the Brazilian medicinal plant Copaifera reticulata Ducke(Leguminosae Caesalpinoideae) against Aedes aegypti (Diptera, Culicidae). Revista da Sociedade Brasileira de Medicina Tropical, Brasília, . .40, n.3, p.264267, 2007.

SILVA, K.L.; CECHINEL FILHO, V. Plantas do gênero bauhinia: composição química e potencial farmacológico. Química Nova, v. 25, n. 3, p.449-454, 2002.

SNOEK-VAN BEURDEN, P.A.M; VON DEN HOFF, J.W. Zymographic techniques for the analysis of matrix metaloproteinases and their inhibitors. BioTechniques, v.38, n.1, p. 73-83, 2005.

SOUTO, L.R.M.; REHDER, J.; VASSALLO, J.; CINTRA, M.L.; KRAEMER, M.H.S.; PUZZI, M.B. Model for human skin reconstructed in vitro composed of associated dermis and epidermis. São Paulo Medical Journal, São Paulo, v.124, n.2, p.71-76, 2006.

SOUZA-JÚNIOR, O.G.; GUIMARÃES-NETO, H.P.; PINTO, N.T.; SANTOS, M.T.; CARVALHO, R.A. Achados macroscópicos na região peritoneal de ratos após aplicação do óleo de copaíba. Revista Paraense de Medicina, Belém, v.16, n.1, p.14-18, 2002.

STADELMANN, W.; DIGENIS, A.G.; TOBIN, G.R. Physiology and healing dynamics of chronic cutaneous wounds. The American Journal of Surgery, v.176, p.26S-38S, 1998.

STEPHENS, P.; WALL, I.B.; WILSON, M.J.; HILL, K.E.; DAVIES, C.E.; HILL, C.M., HARDING,K.G.; THOMAS, D.W. Anaerobic cocci populating the deep tissues of chronic wounds impair cellular wound healing responses in vitro. British Journal of Dermatology, London, v.148, 456-466, 2003.

STOJADINOVIC, A.; CARLSON, J.W.; SCHULTZ, G.S.; DAVIS, T.A.; ELSTER, E.A. Topical advances in wound care. Gynecologic Oncology, New York, v.111, p.S70S80, 2008.

STOTTS, N.A. Wound infection: Diagnosis and Management. In: BRYANT, R.A.; NIX, D.P. Acute and chronic wounds. Current management concepts. 4th ed. Missouri: Elsevier Mosby, 2012. cap.16, p.270-278. 
STRONCEK, JD; BELL, N; REICHERT, WM. Instructional powerpoint presentations for cutaneous wound healing and tissue response to sutures. Journal of Biomedical Materials Research - Part A, Hoboken, v.90, p.1230-1238, 2009.

STUPP, T.; FREITAS, R.A.; SIERAKOWSKI,M.R.; DESCHAMPS, F.C.A.; WISNIEWSKI JR., A.; BIAVATTI, M.W. Characterization and potential uses of Copaifera langsdorffii seeds and seed oil. Bioresource Technology, New York, v.99, n.7, p.2659-2663, 2007.

SULLIVAN, P.K.; CONNER-KERR, T.A.; HAMILTON, H.; SMITH, E.P.; TEFERTILLER, C.; WEBB, A. Assessment of wound bioburden development in a rat acute wound model: quantitative swab versus tissue biopsy. Wounds, King of Prussia, v.16, n.4, 2004.

SUNDSTROM, L.; MORRISON III, B.; BRADLEY, M.; PRINGLE,A. Organotypic cultures as tools for functional screening in the CNS. Drug Discovery Today, Oxford, v.10, n.14, p.993-1000, 2005.

SWAMY, SMK; TAN, P; ZHU, YZ; LU, J; ACHUT, HN; MOOCHHALA, S. Role of phenytoin in wound healing: microarray analisys of early transcriptional responses in human dermal fibroblasts. Biochemical and Biophysical Research Communications, New York, v.314, p.661-666, 2004.

TANG, Z.; YANG, L.; ZHANG, J.; XUE, R.; WANG, Y.; CHEN, P.C.; SUNG, K.L.P. Coordinated expression of MMPs and TIMPs in rat knee intra-articular tissues after ACL injury. Connective Tissue Research, London, v.50, p.315-322, 2009.

TORTORA, G.F.; FUNKE, B.R.; CASE, C.L. Microbial growth. In: Microbiology: An introduction. 6th ed. California: Benjamin/ Cummnigs Publishing Company, 2005. p.154-180.

UPPAL, S.K.; RAM, S.; KWATRA, B.; GARG, S.; GUPTA, R. Comparative evaluation of surface swab and quantitative full thickness wound biopsy culture in burn patients. Burns, Guildford, v.33, p. 460-463, 2007.

VALDEVITE, L.M. Estudo do efeito in vitro de extrato das folhas e do óleoresina de copaíba sobre os fatores de virulência de Streptococcus mutans, relacionados à cárie dental. 2007. 128 f. Dissertação (Mestrado) - Faculdade de Ciências Farmacêuticas de Ribeirão Preto, Universidade de São Paulo, Ribeirão Preto, 2007.

VEIGA JUNIOR, V.F.; ROSAS, E.C.; CARVALHO, M.V.; HENRIQUES, M.G.M.O.; PINTO, A.C. Chemical composition and anti-inflammatory activity of copaiba oils from Copaifera cearensis Huber ex Ducke, Copaifera reticulata Ducke and Copaifera 
multijuga Hayne-A comparative study. Journal of Ethnopharmacology, Limerick, v.112, n.2, p.248-254, 2007.

VEIGA JÚNIOR, V.F.; ZUNINO, L.; PATITUCCI, M.L.; PINTO, A.C.; CALIXTO, J.B. The inhibition of paw oedema formation caused by the oil of Copaifera multijuga Hayne and its fractions. Journal of Pharmacy and Pharmacology, London, v.58, p.1405-1410, 2006.

VEIGA JÚNIOR, V.F.; PINTO, A.C.; MACIEL, M.A.M. Plantas medicinais: cura segura? Química nova, v.28, n.3, p.519-28, 2005.

VEIGA JÚNIOR, V.F.; PINTO, A.C. O gênero Copaífera L. Química Nova, v.25, n.2, p.273-286, 2002.

VEIGA JÚNIOR, V.F.; ZUNINO, L.; CALIXTO, J.B.; PATITUCCI, M.L.; PINTO, A.C. Phytochemical and antioedematogenic studies of commercial copaiba oils available in Brazil.Phytotherapy Research, London, v.15, 476-480, 2001.

VEIGA JÚNIOR, V.F.; PATITUCCI, M.L.; PINTO, A.C. Controle de autenticidade de óleos de copaíba comerciais por cromatografia gasosa de alta resolução. Química Nova, v.20, n.6, p.612-615, 1997.

WALL, S.J.; BEVAN, D.; THOMAS, D.W.; HARDING, K.G.; EDWARDS, D.R.; MURPHY, G. Differential expression of matrix metalloproteinases during impaired wound healing of the diabetes mouse. Journal of Investigative Dermatology, Baltimore, v. 119, p.91-98, 2002.

WARRINER, R.; ROBERT BURRELL, R. Infection and the chronic wound: A focus on silver. Advances in Skin and Wound Care, Springhouse, v.18, p.2-12, 2005. Supplement 1.

WITTE, M.B.; BARBUL, A. General principles of wound healing. Surgical Clinics of North America, Philadelphia, v.77, n.3, p.509-528, 1997.

WYSOCKI, A.B. Anatomy and physiology of skin and soft tissue. In: BRYANT, R.A.; NIX, D.P. Acute and chronic wounds. Current management concepts. 4th ed. Missouri: Elsevier Mosby, 2012. cap.3, p.40-62.

XIE, J.L.; BIAN, H.N.; QI, S.H.; CHEN, H.D.; LI, H.D.; XU, Y.B.; LI, T.Z.; LIU, X.S.; LIANG, H.Z.; XIN, B.R.; HUAN, Y. Basic fibroblast growth factor (bFGF) alleviates the scar of the rabbit ear model in wound healing. Wound Repair and Regeneration, Saint Louis, v.16, p.576-581, 2008. 


\section{Apêndices}

"Nunca desista por medo de fracassar, pois o fracasso não é ofim de tudo e sim, uma parte do caminho para alcançar o sucesso". Roberto Shinyashiki 


\section{APÊNDICES}

\section{APÊNDICE A - Soluções utilizadas para a dosagem de hidroxiprolina}

\begin{tabular}{|c|c|c|}
\hline \multirow[t]{3}{*}{$\checkmark$} & \multicolumn{2}{|l|}{ Ácido Clorídrico 6N } \\
\hline & Ácido Clorídrico $12 \mathrm{~N}, \ldots \ldots \ldots \ldots \ldots \ldots \ldots \ldots \ldots \ldots \ldots \ldots \ldots \ldots$ & $49,6 \mathrm{~mL}$ \\
\hline & Água destilada $\ldots \ldots \ldots \ldots \ldots \ldots \ldots \ldots \ldots \ldots \ldots \ldots \ldots$ & qsp $100 \mathrm{~mL}$ \\
\hline \multirow[t]{6}{*}{$\checkmark$} & \multicolumn{2}{|l|}{ Tampão Citrato-Acetato pH 6,5 } \\
\hline & Acetato de Sódio tri-hidratado ................ & $120 \mathrm{~g}$ \\
\hline & 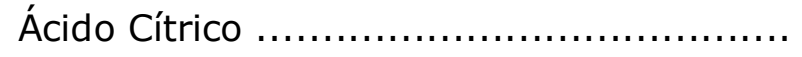 & $34 \mathrm{~g}$ \\
\hline & 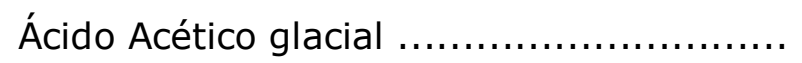 & $12 \mathrm{~mL}$ \\
\hline & 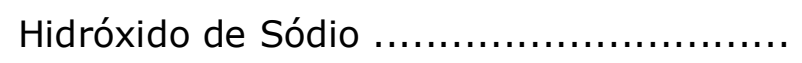 & $34 \mathrm{~g}$ \\
\hline & Água destilada.$\ldots \ldots \ldots \ldots \ldots \ldots \ldots \ldots \ldots \ldots \ldots \ldots \ldots \ldots \ldots \ldots$ & qsp $1 \mathrm{~L}$ \\
\hline \multirow[t]{3}{*}{$\checkmark$} & \multicolumn{2}{|l|}{ Hidróxido de Sódio $2 M$} \\
\hline & Hidróxido de Sódio $\ldots \ldots \ldots \ldots \ldots \ldots \ldots \ldots \ldots \ldots \ldots \ldots \ldots \ldots \ldots \ldots \ldots$ & $8,0 \mathrm{~g}$ \\
\hline & Água destilada $\ldots \ldots \ldots \ldots \ldots \ldots \ldots \ldots \ldots \ldots \ldots \ldots \ldots \ldots \ldots \ldots$ & qsp $100 \mathrm{~mL}$ \\
\hline \multirow[t]{4}{*}{$\checkmark$} & \multicolumn{2}{|l|}{ Chloramina T 0,056M } \\
\hline & Chloramine $\mathrm{T}$ (Sigma) $\ldots \ldots \ldots \ldots \ldots \ldots \ldots \ldots \ldots \ldots \ldots \ldots$ & $0,127 \mathrm{~g}$ \\
\hline & n-propanol ( $50 \%$ em água destilada) ...... & $2,0 \mathrm{~mL}$ \\
\hline & Tampão Citrato-Acetato ........................ & qsp $10 \mathrm{~mL}$ \\
\hline \multirow[t]{3}{*}{$\checkmark$} & \multicolumn{2}{|l|}{ Solução estoque de hidroxiprolina } \\
\hline & Trans-4-hydroxy-L-proline (Sigma) ........... & $0,025 \mathrm{~g}$ \\
\hline & Tampão Citrato-Acetato $\mathrm{pH}$ 6,5 ............... & qsp $25 \mathrm{~mL}$ \\
\hline \multirow[t]{3}{*}{$\checkmark$} & \multicolumn{2}{|l|}{ Reagente de Ehrlich 1M } \\
\hline & 4-(Dimethylamino) benzaldehyde (Sigma) . & $1,5 \mathrm{~g}$ \\
\hline & n-propanol/ Ácido Perclórico $(2: 1) \ldots \ldots \ldots . .$. & qsp $10 \mathrm{~mL}$ \\
\hline
\end{tabular}

A partir da solução estoque de hidroxiprolina, preparou-se uma solução na concentração de $100 \mu \mathrm{g} / \mathrm{mL}$ e a partir desta preparou-se as soluções para a curva padrão. 


\section{APÊNDICE B - Soluções utilizadas para a dosagem de MMPs}

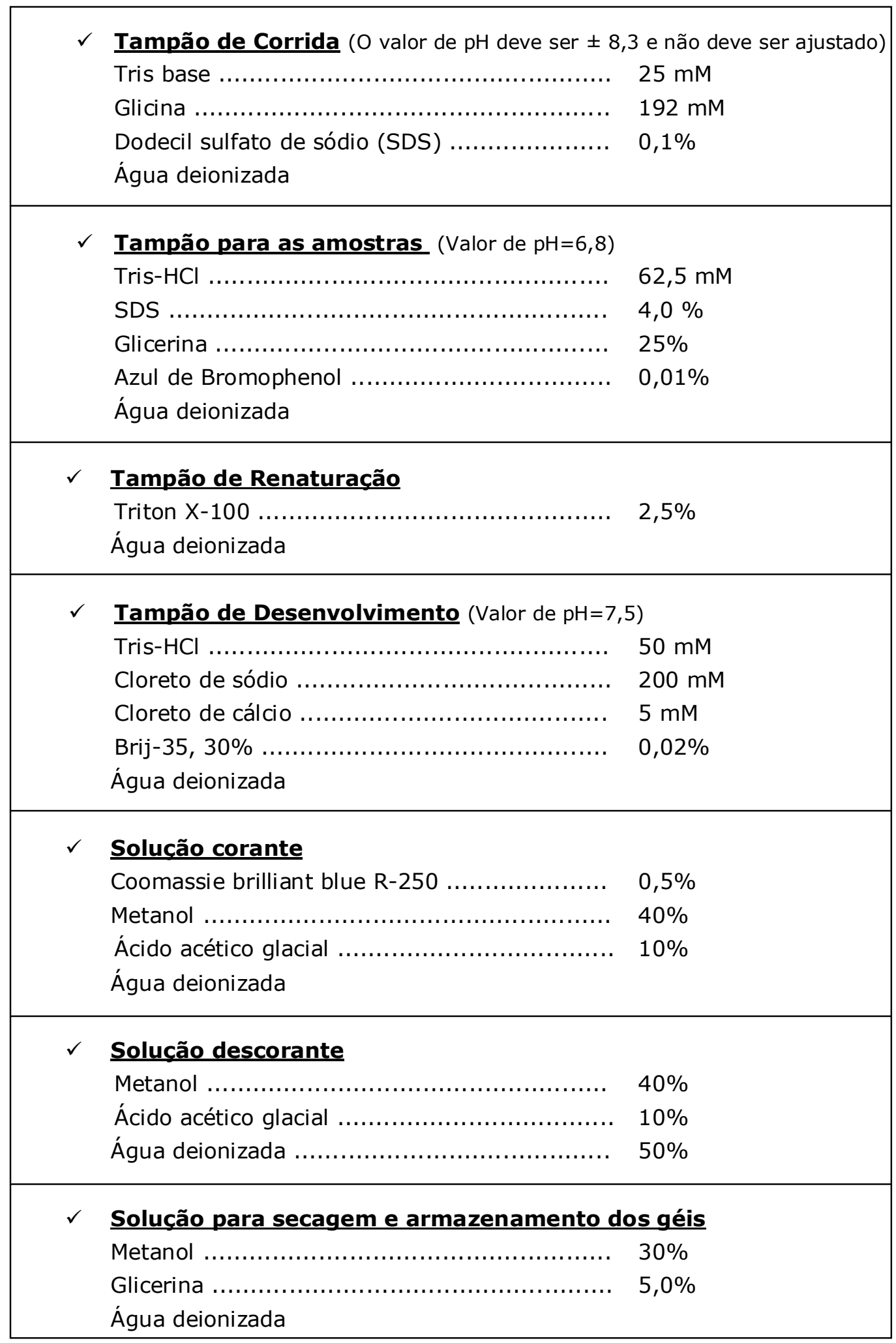




\section{Anexos}

"Viver é acalentar sonhos e esperanças, fazendo da fé a nossa inspiração maior. É buscar nas pequenas coisas um grande motivo para ser feliz". Mário Quintana 


\section{ANEXOS}

\section{ANEXO A - Parecer do Comitê de Ética em Experimentação Animal (FMRP-USP)}
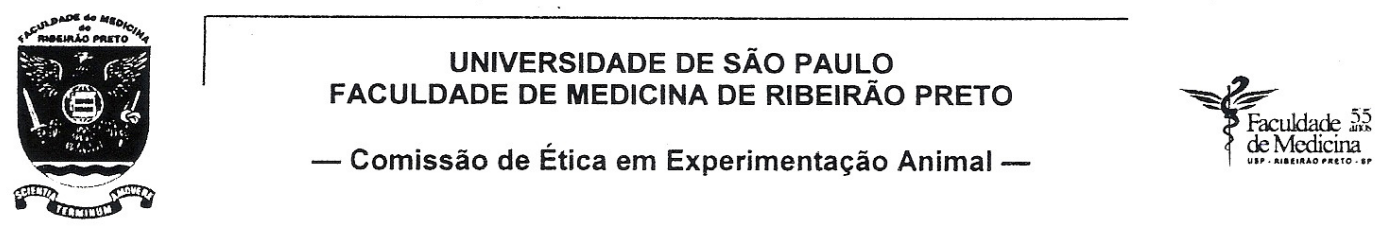

\section{CE R T I F I C A D O}

Certificamos que o Protocolo para Uso de Animais em Experimentação $n^{\circ}$ 048/2007, sobre o projeto intitulado "Padronização do modelo de curativo para úlceras cutâneas em coelhos e avaliação do potencial cicatrizante do óleo de copaíba", sob a responsabilidade do Professor Doutor Marco Andrey Cipriani Frade, está de acordo com os Princípios Éticos na Experimentação Animal adotado pelo Colégio Brasileiro de Experimentação Animal (COBEA) e foi $A P R O V A D O$ pela COMISSÃO DE ÉTICA EM EXPERIMENTAÇÃO ANIMAL (CETEA) em reunião de 02 de julho de 2007.

(We certify that the protocol $n^{\circ} 048 / 2007$, about "Standardization of dressing model for cutaneous wounds in rabbits and evaluation of the healing potential of copaiba oil", agrees with the ETHICAL PRINCIPLES IN ANIMAL RESEARCH adopted by Brazilian College of Animal Experimentation (COBEA) and was approved by the COLLEGE OF MEDICINE OF RIBEIRÃO PRETO OF THE UNIVERSITY OF SÃO PAULO - ETHICAL COMMISSION OF ETHICS IN ANIMĄL RESEARCH (CETEA) in 07/02/2007 meeting).

Ribeirão Preto, 10 de julho de 2007.

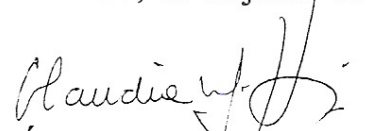

Profa. Dra. CLÁUDIA MARIA LEITE MAFFEI

Vice-Presidente da Comissão de Ética em Experimentação Animal, em exercício 


\section{ANEXO B - Parecer do Comitê de Ética em Pesquisa (HCRP-FMRP-USP)}

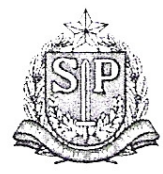

wwwherp.fmrp.usp.br

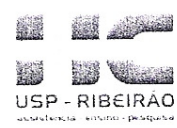

Ribeirão Preto, 10 de junho de 2008

Oficio $n^{\circ} 2038 / 2008$

$\mathrm{CEP} / \mathrm{MGV}$

PROCESSO HCRP n n $^{\circ} 606 / 2008$

Prezado Professor,

O Comitê de Ética em Pesquisa analisou "AD

REFERENDUIM" a proposta de "Criação do banco de amostras biológicas da Dermatologia” e a enquadrou na categoria: APROVADO, bem como o Termo de Consentimento de guarda do material.

Atenciosamente.

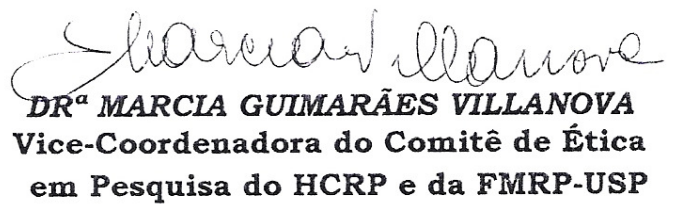

Ilustrissimo Senhor

PROF. DR. MARCO ANDREY CIPRIANI FRADE

Depto. de Clinica Médica - Dermatologia

Comitê de Ética em Pesquisa HCRP e FMRP-USP - Campus Universitário

FWA-00002733; IRB-00002186 e Registro SISNEP/CONEP n ${ }^{\circ} 4$

Fone (16) 3602-2228 - E-mail : cep@hcrp.fmrp.usp.br

Monte Alegre 14048-900 Ribeiräo Preto SP 


\section{ANEXO C - Parecer do Comitê de Ética Animal (UWM, EUA)}

UNIVERSITY of WISCONSIN

UWMILWAUKEE

Institutional Animal Care and Use Committee

Animal Care Program

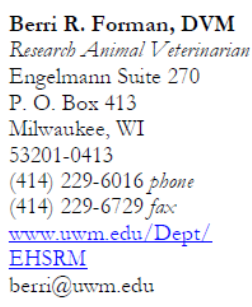

Date: $\quad$ February 18,2010

To: $\quad$ Chukuka S. Enwemeka, Principal Investigator

From: $\quad$ Berri Forman, Research Animal Veterinarian

Re: $\quad$ Protocol 09-10 \#20, entitled, "Assessment of healing potential and antimicrobial activity of copaiba oil in cutaneous wounds"

Protocol number 09-10 \#20 was reviewed by the IACUC's designated review process and approved on February 17, 2010. The approval will remain in effect for up to a three-year period. IACUC protocol approval does not automatically guarantee that the approved project can be started. The Animal Resource Center (ARC) must be able to accommodate the project at the time. You will be contacted prior to the end of one year to meet requirements for continual IACUC review. If you have any modifications, please submit them to Berri Forman in the Department of University Safety and Assurances (229-6016/6339) to arrange for a review.

Please use this protocol number to identify the animals on this project.

Thank you for your cooperation, and best wishes for a successful project.

cc: $\quad$ Protocol File

Renewal File 


\section{ANEXO D - Parecer do Comitê de Biossegurança (UWM, EUA)}

UNIVERSITY of WISCONSIN

\section{UUMILWAUKEE}

\section{Department of University Safety \& Assurances} Biological Safety Program

DATE: $\quad$ February 26, 2010

TO: $\quad$ Chukuka Enwemeka, Principal Investigator

FROM: $\quad$ Sharron A. Daly, Biological Safety Officer
"Assessment of Healing Potential and Antimicrobial Activity of Copaiba Oil in Cutaneous Wounds" (\#10-Enwemeka-01)
Sharron A. Daly Radiation Safety Officer Biolgoical Safety Office Lapham Hall W217 P. O. Box 413 Milwaukee, WI

$53201-0413$

(414) 229-4275 phone

(414) 229-6729 fax

wwww.safety.uwm.edu sdalv@uwm.edu

The work outlined in your protocol entitled "Assessment of Healing Potential and Antimicrobial Activity of Copaiba Oil in Cutaneous Wounds" has been reviewed by a subcommittee of the Institutional Biosafety Committee and is approved as outlined in the materials submitted.

Registration of this protocol will be valid for up to three years. Should you have a need to amend or modify the work outlined in this protocol please contact me to arrange for a review and modified registration.

Thank you for your cooperation and best wishes for a successful research project.

Cc: $\quad$ Protocol File

B. Burlage, Chair

B. Forman, IACUC

V. Bumah, Health Sciences 